University of South Florida

DIGITAL COMMONS

@ UNIVERSITY OF SOUTH FLORIDA
Digital Commons @ University of

South Florida

3-1-2012

\title{
An Assessment of Public Transportation Markets Using NHTS Data
}

CUTR

Follow this and additional works at: https://digitalcommons.usf.edu/cutr_nctr

\section{Recommended Citation}

"An Assessment of Public Transportation Markets Using NHTS Data," National Center for Transit Research (NCTR) Report No. CUTR-NCTR-RR-2010-08, Center for Urban Transportation Research, University of South Florida, 2012.

DOI: https://doi.org/10.5038/CUTR-NCTR-RR-2010-08

Available at: https://scholarcommons.usf.edu/cutr_nctr/122

This Technical Report is brought to you for free and open access by the National Center for Transit Research (NCTR) Archive (2000-2020) at Digital Commons @ University of South Florida. It has been accepted for inclusion in Research Reports by an authorized administrator of Digital Commons @ University of South Florida. For more information, please contact digitalcommons@usf.edu. 


\section{An Assessment of Public Transportation Markets Using NHTS Data}

Final Report

Prepared by Xuehao Chu, Ph.D. National Center for Transit Research at CUTR University of South Florida, Tampa March 2012

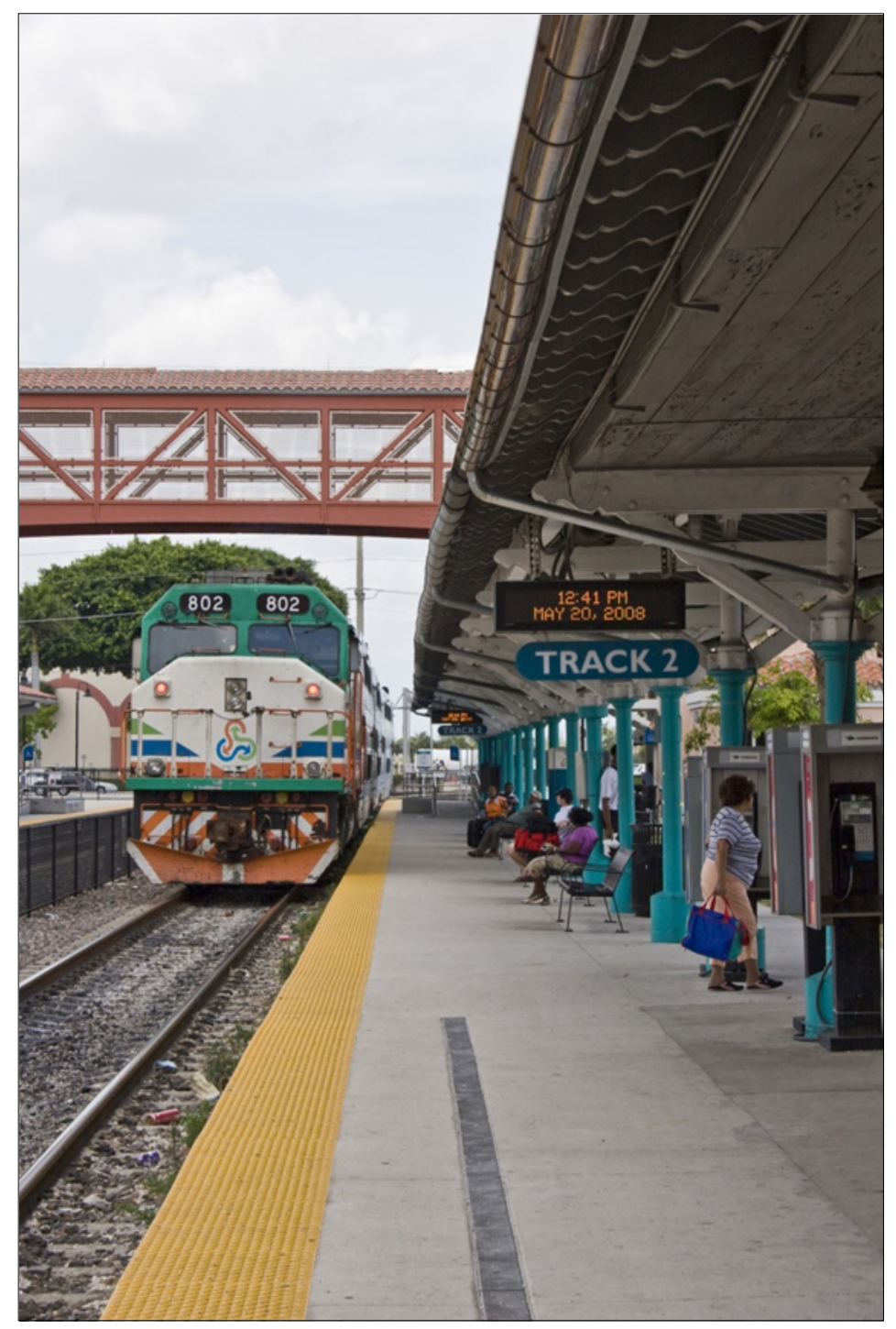

Prepared for Florida Department of Transportation Contract Number: BDK85 977-17 


\section{DISCLAIMER}

The opinions, findings, and conclusions expressed in this publication are those of the author and not necessarily those of the State of Florida Department of Transportation or the U.S. Department of Transportation.

The report was prepared in cooperation with the State of Florida Department of Transportation and the U.S. Department of Transportation. 


\section{METRIC CONVERSION TABLE FOR LENGTH}

\begin{tabular}{|c|c|c|c|c|}
\hline Symbol & When you know & Multiply by & To find & Symbol \\
\hline $\mathrm{mi}$ & miles & 1.61 & kilometers & $\mathrm{km}$ \\
$\mathrm{km}$ & kilometers & 0.621 & miles & $\mathrm{mi}$ \\
\hline
\end{tabular}




\section{TECHNICAL REPORT DOCUMENTATION PAGE}

\begin{tabular}{|c|c|c|c|}
\hline 1. Report No. & 2. Government Accession No. & \multicolumn{2}{|c|}{ 3. Recipient's Catalog No. } \\
\hline \multirow{2}{*}{\multicolumn{2}{|c|}{$\begin{array}{l}\text { 4. Title and Subtitle } \\
\text { An Assessment of Public Transportation Markets Using NHTS Data }\end{array}$}} & \multicolumn{2}{|c|}{$\begin{array}{l}\text { 5. Report Date } \\
\text { March } 2012\end{array}$} \\
\hline & & \multicolumn{2}{|c|}{ 6. Performing Organization Code } \\
\hline \multicolumn{2}{|l|}{$\begin{array}{l}\text { 7. Author(s) } \\
\text { Xuehao Chu }\end{array}$} & \multicolumn{2}{|c|}{$\begin{array}{l}\text { 8. Performing Organization Report No. } \\
\text { NCTR779-20, } \\
\text { FDOT BDK85 } 977-17\end{array}$} \\
\hline \multirow{2}{*}{\multicolumn{2}{|c|}{$\begin{array}{l}\text { 9. Performing Organization Name and Address } \\
\text { National Center for Transit Research (NCTR) } \\
\text { University of South Florida } \\
4202 \text { E Fowler Ave., CUT100, Tampa, FL } 33620-5375\end{array}$}} & \multicolumn{2}{|c|}{ 10. Work Unit No. } \\
\hline & & \multicolumn{2}{|c|}{$\begin{array}{l}\text { 11. Contract or Grant No. } \\
\text { U.S.DOT DTRS98-G-0032 }\end{array}$} \\
\hline \multirow{2}{*}{\multicolumn{2}{|c|}{$\begin{array}{l}\text { 12. Sponsoring Agency Name and Address } \\
\text { Research and Innovative Technology Administration } \\
\text { U.S. Department of Transportation, Washington, D.C. } 20590\end{array}$}} & \multicolumn{2}{|c|}{$\begin{array}{l}\text { 13. Type of Report and Period Covered } \\
\text { Final Report } \\
\text { Nov } 2009 \text { - March } 2012\end{array}$} \\
\hline & & \multicolumn{2}{|c|}{ 14. Sponsoring Agency Code } \\
\hline \multicolumn{4}{|c|}{$\begin{array}{l}\text { 15. Supplementary Notes } \\
\text { Supported by a grant from the Florida Department of Transportation and the U.S. Department of } \\
\text { Transportation }\end{array}$} \\
\hline \multicolumn{4}{|c|}{$\begin{array}{l}\text { 16. Abstract } \\
\text { This study assesses a range of public transit markets for Florida and the U.S. as a whole. Data from the } \\
2009 \text { National Household Travel Survey are used. The public transit markets are defined with trip } \\
\text { purpose and seven personal, household, and travel characteristics of persons in these transit markets, } \\
\text { including driver status, immigration status, existence of medical conditions that make it difficult to travel } \\
\text { out of the home, household income, vehicle availability, race and ethnicity, and monthly frequency of } \\
\text { transit use. Based on an approach of cross tabulations, this study assesses these transit markets from } \\
\text { five perspectives: } \\
\text { 1. Market Size - how the overall transit market is distributed across these transit sub-markets. } \\
\text { 2. Modal Share - how people within each transit market travel using various modes, including transit. } \\
\text { 3. Attitudes - how people within each transit market feel about a set of transportation issues. } \\
\text { 4. Socio-Demographics - personal, household, location, and travel characteristics of transit markets. } \\
\text { 5. Trip Characteristics - transit-specific and general trip characteristics of transit markets. } \\
\text { The assessment for Florida is limited to the first three perspectives due to sample size issues. The } \\
\text { results presented are useful to operating agencies for strategic planning and to other government bodies } \\
\text { for developing policies and funding programs for improving mobility of those who are transportation and } \\
\text { economically disadvantaged and for improving the transportation system in general. }\end{array}$} \\
\hline $\begin{array}{l}\text { 17. Key Words } \\
\text { Public Transit, National } \\
\text { Household Travel Survey, } \\
\text { Person-Trips, Modes, Trip } \\
\text { Purposes }\end{array}$ & \multicolumn{3}{|c|}{$\begin{array}{l}\text { 18. Distribution Statement } \\
\text { Available to the public through the National Technical Information } \\
\text { Service (NTIS), } 5285 \text { Port Royal Road, Springfield, VA } 22161 \text {, } \\
\text { (703) } 487-465 \text {, and through the NCTR website at } \\
\text { http://www.nctr.usf.edu }\end{array}$} \\
\hline $\begin{array}{l}\text { 19. Security Classif. (of this report) } \\
\text { Unclassified }\end{array}$ & $\begin{array}{l}\text { 20. Security Classif. (of this page) } \\
\text { Unclassified }\end{array}$ & $\begin{array}{l}\text { 21. No. of pages } \\
147\end{array}$ & 22. Price \\
\hline
\end{tabular}

Form DOT F 1700.7 (8-72) Reproduction of completed page authorized 


\section{ACKNOWLEDGMENT}

The author thanks Patricia Ball, Steve Polzin, and Joel Volinski of the Center for Urban

Transportation Research at the University of South Florida for their careful reviews. All remaining errors and shortcomings are the author's responsibility. 


\section{EXECUTIVE SUMMARY}

\section{Background}

A current and good understanding of transit markets is critical for both operating agencies and policy bodies and funding agencies. Unlike operating agencies, policy bodies and funding agencies do not have a frequently-available source of data for acquiring such an understanding for more aggregated geographies than local service areas. Through "A Profile of Public Transportation Passenger Demographics and Travel Characteristics Reported in On-Board Surveys," the American Public Transportation Association (APTA) in 2007 assessed public transit markets at the national level. The assessment is based on tabulated data from 150 transit on-board surveys collected from 2000 to 2005 by operating agencies throughout the country. It is limited to the relative sizes of individual transit markets. The latest 2009 National Household Travel Survey (NHTS) provides a unique opportunity for gaining insights into public transit markets beyond the APTA study. The survey contains significantly more data than previous surveys in the NHTS series and allows a richer and statistically more meaningful assessment of transit markets. Specifically, it has a large sample size of 150,147 households for the U.S., including 15,884 households for Florida.

\section{Objectives}

The objective of the current study is to define and assess a range of transit markets in Florida and the U.S. from a range of perspectives.

\section{Findings and Conclusions}

This study uses six socio-demographics and two travel characteristics to define transit markets. The socio-demographics are driver status, immigration status, existence of medical conditions, household income, vehicle availability, and race and ethnicity. The travel characteristics are monthly frequency of transit use and the purpose of person-trips. These characteristics for defining transit markets result from several considerations. For each of these characteristics, two to four market segments are defined using knowledge from the literature about differences in transit use, differences in policy concerns across these segments, and adequate sample size for each segment. This study has assessed these markets from several perspectives:

- For the set of market segments based on a given characteristic, it determines their market sizes for public transit by looking at how all transit trips are distributed across them. This assessment, for example, determines that at 6.1 percent of the total U.S. population, zerovehicle households represent the largest transit market, capturing more than 48.5 percent of the entire transit market in the U.S. It also determines that 18.9 percent of the total U.S. population use transit during an average month. In addition, this assessment determines that at less than 5 percent of the Florida population, new immigrants (entered the U.S. during 2000-2009) represent almost one-quarter of the transit market in Florida. 
- For each market segment, it determines the mode choices of its population among driving, riding in a privately-operated vehicle (POV), using transit, walking, and biking. This assessment reveals that both persons in zero-vehicle households and the most frequent users of transit rely on transit for more than one-quarter of their daily travel, but transit still plays only a minor role for most other transit markets, including non-drivers and persons from extremely low-income households. This assessment also shows that biking is rarely used as a mode of transportation across all transit markets, including adults who do not drive and persons in zero-vehicle households.

- It assesses the attitudes of each transit market in terms of its choice of the most important issue among a set of six pre-specified transportation issues and its view on the seriousness of each issue. This assessment determines, for example, that more than one-third of most transit markets consider access to and availability of transit as their most important issue, but well under one-tenth of most transit markets considers lack of walkways and sidewalks as their most important issue.

- It assesses the socio-demographics of each transit market, i.e., the distribution of its transit trips across a set of population segments defined on the basis of these socio-demographics. This assessment determines, for example, that 43.7 percent of the transit trip makers who live in zero-vehicle households also live in households with income under $\$ 15,000$, but 74.1 percent of the transit trip makers who live in households with income under $\$ 15,000$ also live in zero-vehicle households.

- It assesses the trip characteristics of each transit market. This assessment determines, for example, that the percent of transit trips for work purposes varies significantly across transit markets, with just 9.7 percent among non-drivers, 12.4 percent among persons using transit 1-9 times a month, 55.6 percent among persons with household income at least $\$ 100,000$, and 57.1 percent among persons living in households with fewer vehicles than workers.

\section{Benefits}

The assessment of public transit markets in this study serves purposes relevant to policy bodies and funding agencies. Operating agencies also can use it as a benchmark against which their own transit markets may be compared. In addition, it can provide critical information on the current conditions of various transit markets as part of a complete picture that also includes their past trends and future possibilities.

This project was conducted by Dr. Xuehao Chu of the Center for Urban Transportation Research at the University of South Florida in Tampa. For more information, contact Diane Quigley, FDOT Transit Planning Project Manager, at (850) 414-4520, diane.quigley@dot.state.fl.us. 


\section{TABLE OF CONTENTS}

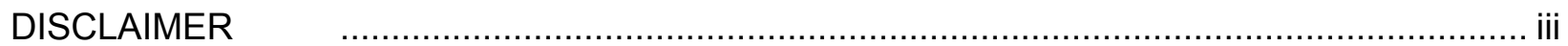

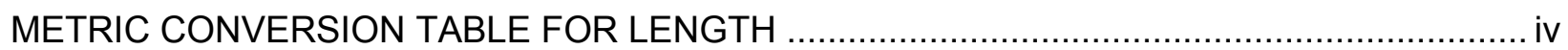

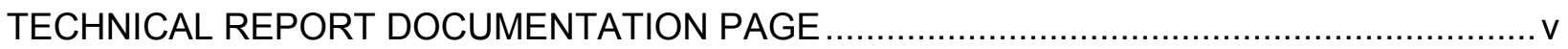

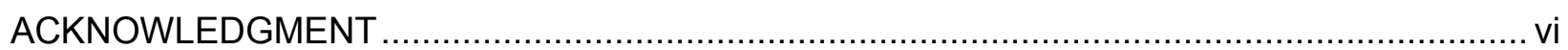

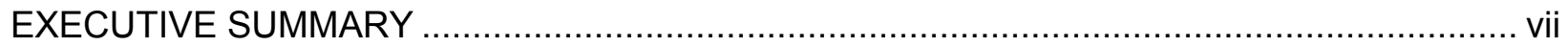

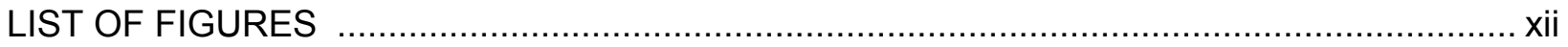

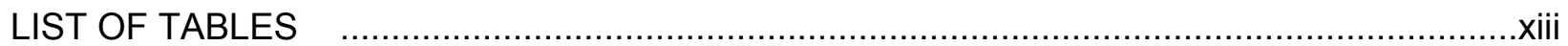

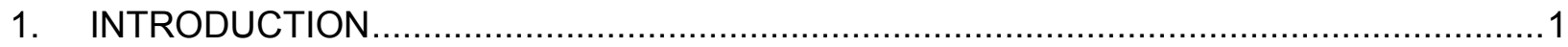

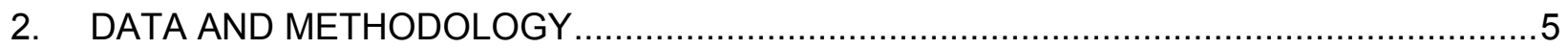

2.1 Data

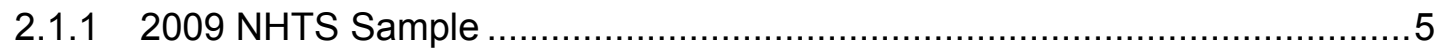

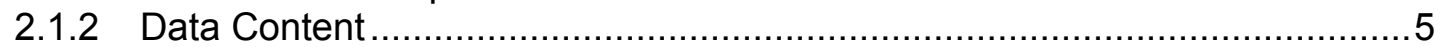

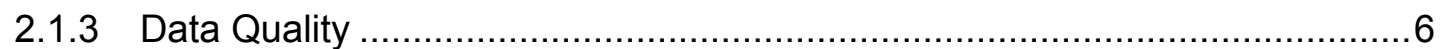

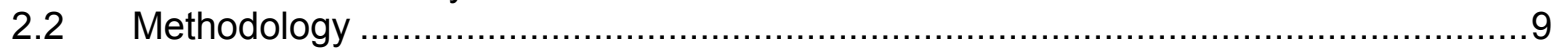

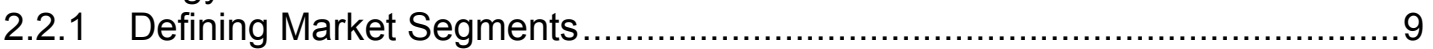

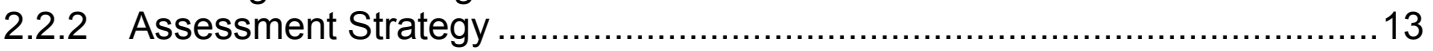

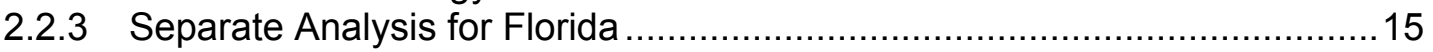

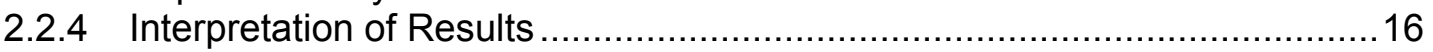

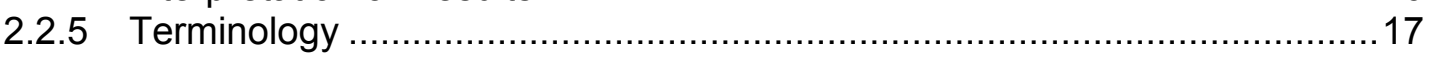

3. SIZE AND MODAL SHARES OF MARKET SEGMENTS .......................................19

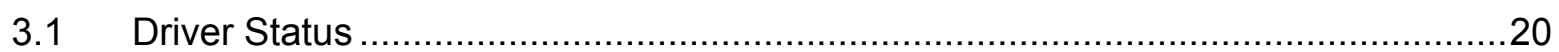

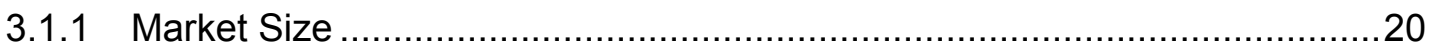

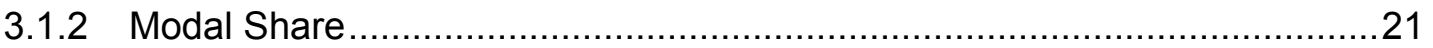

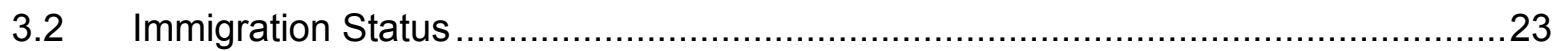

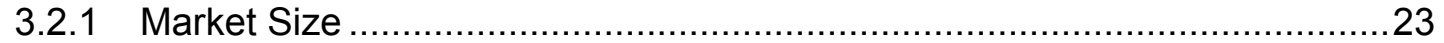

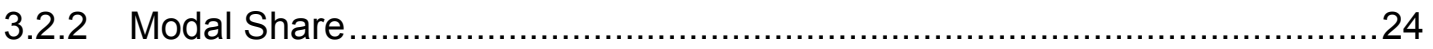

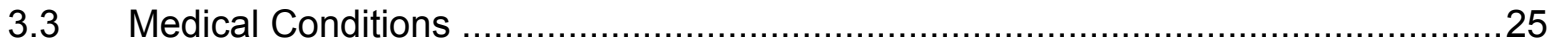

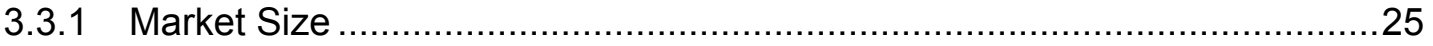

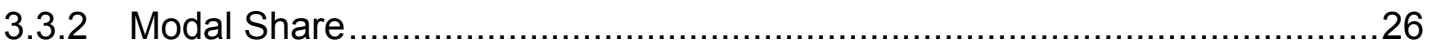

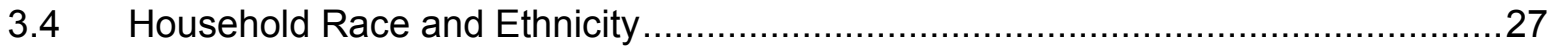

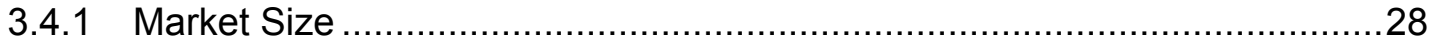

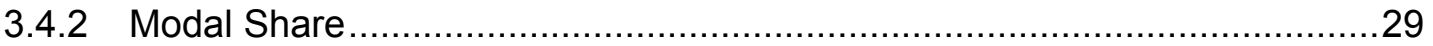

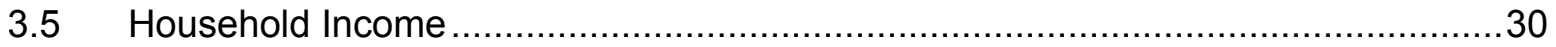

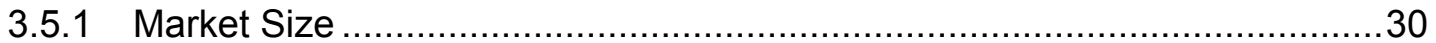

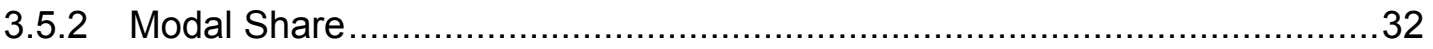

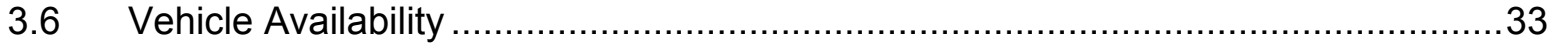

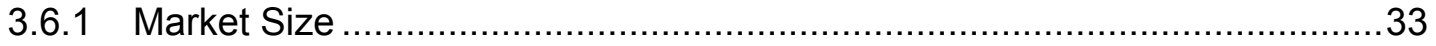

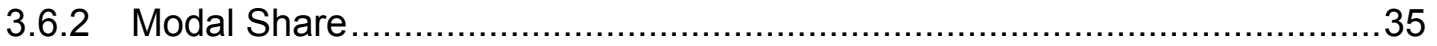

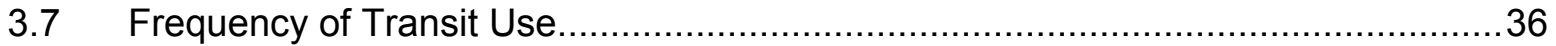

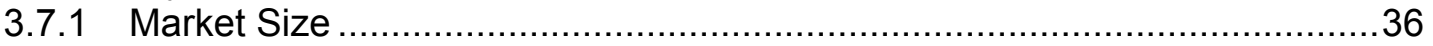

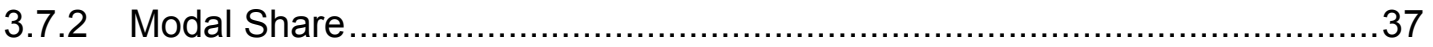

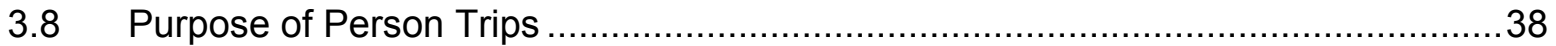

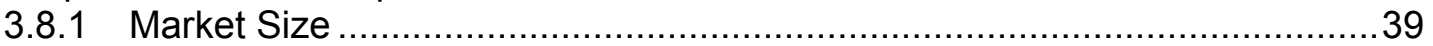




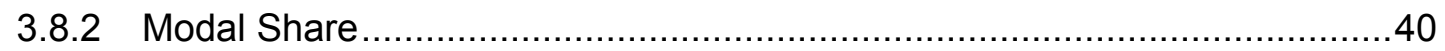

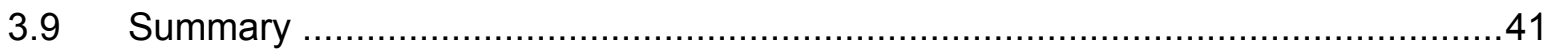

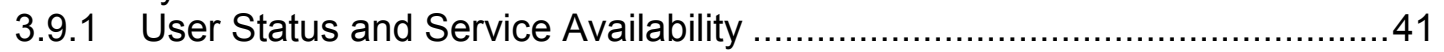

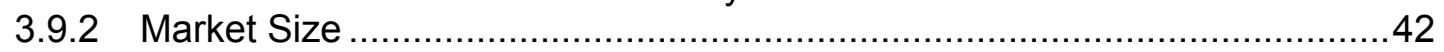

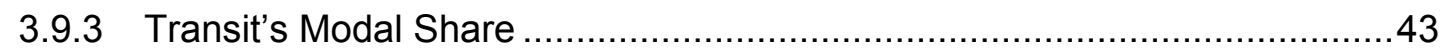

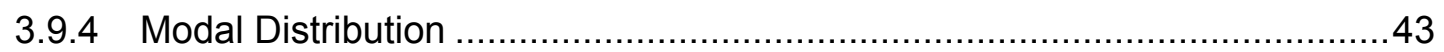

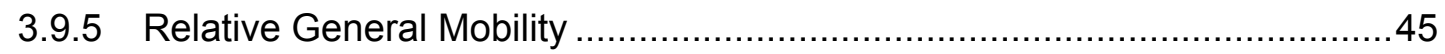

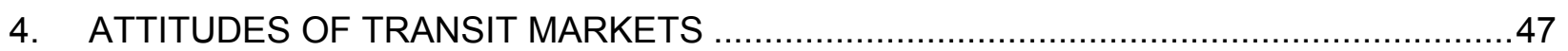

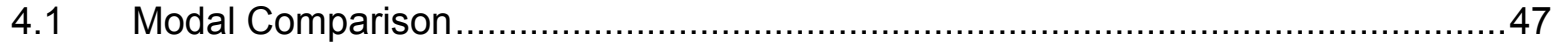

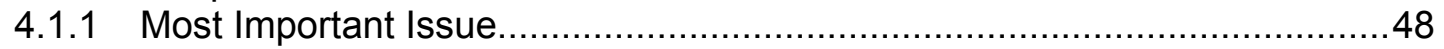

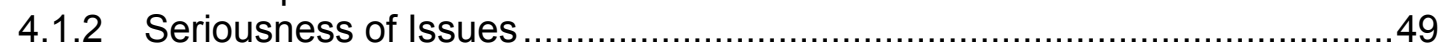

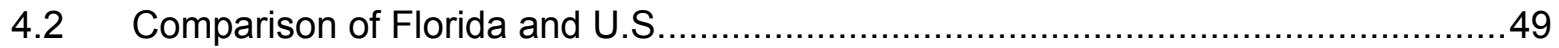

4.2.1 Most Important Issue .......................................................................50

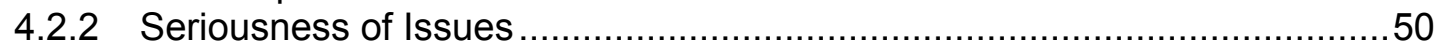

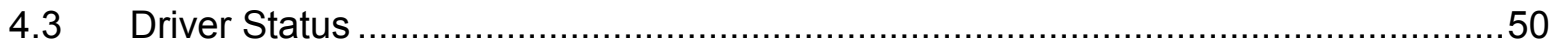

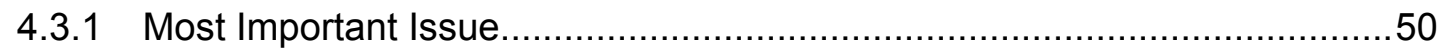

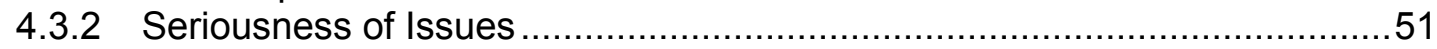

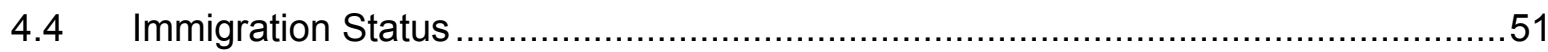

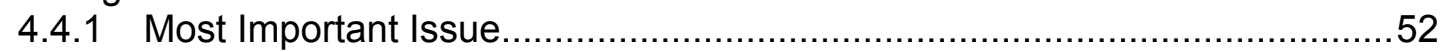

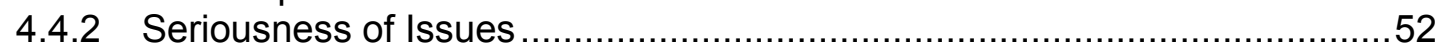

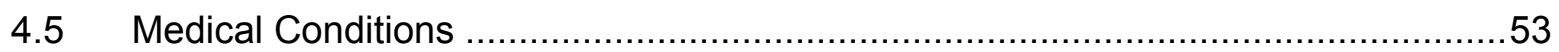

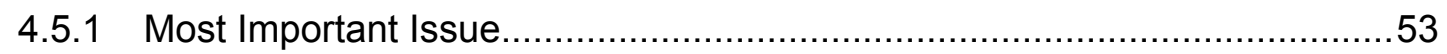

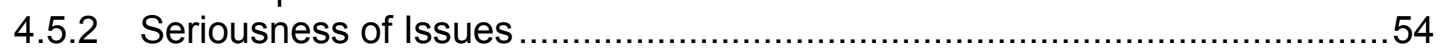

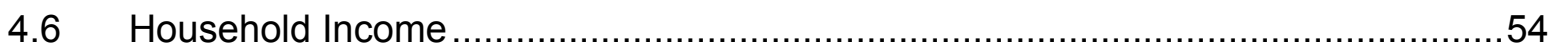

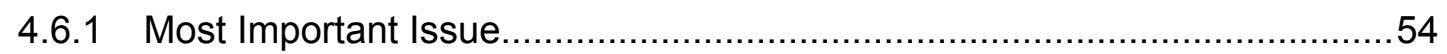

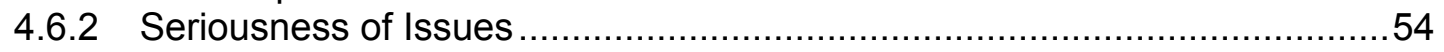

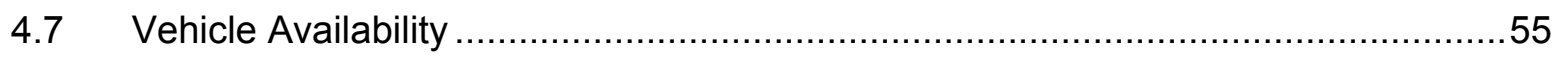

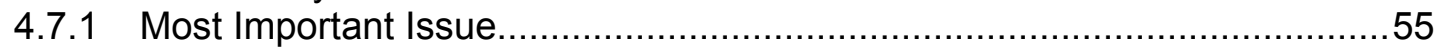

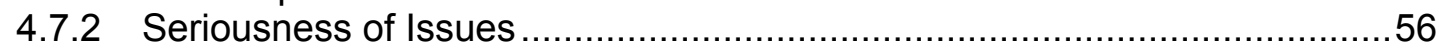

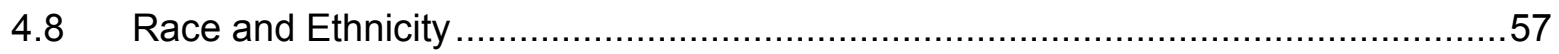

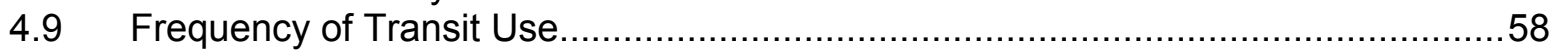

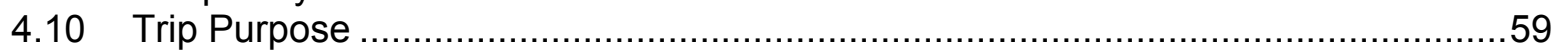

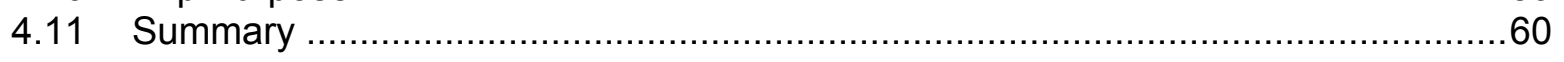

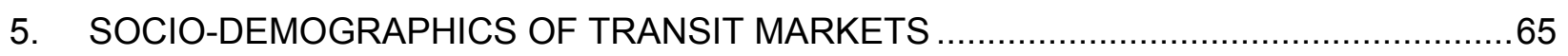

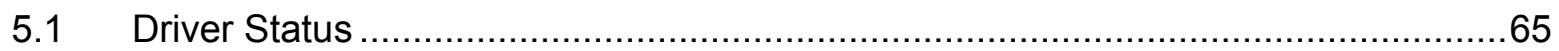

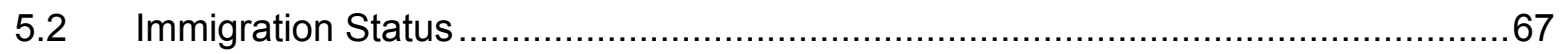

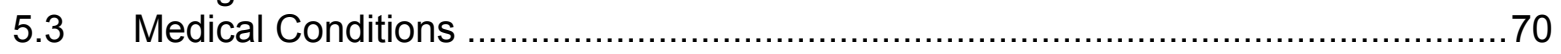

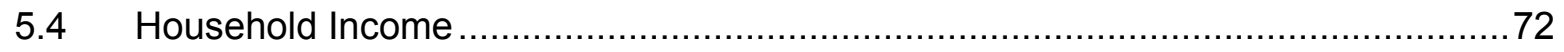

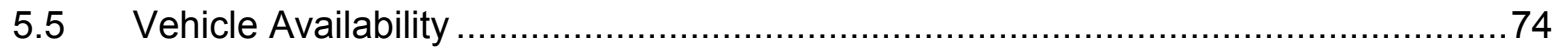

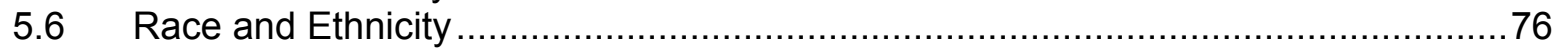

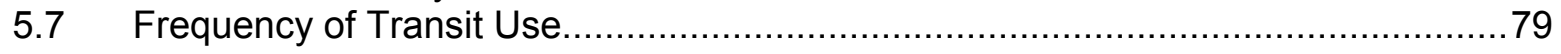

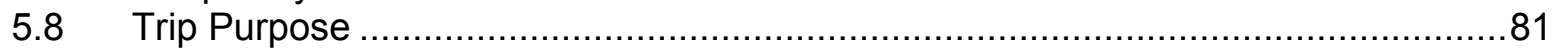

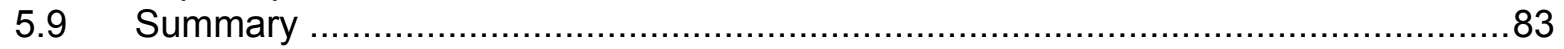

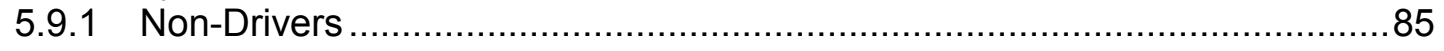

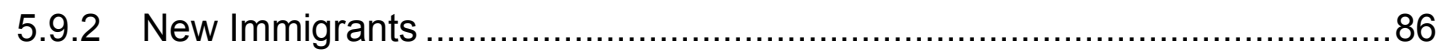

5.9.3 Having Medical Conditions ............................................................... 88



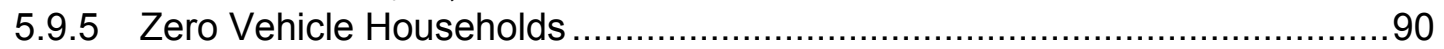

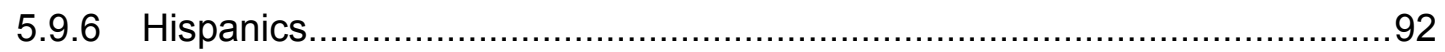

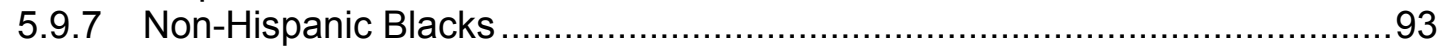




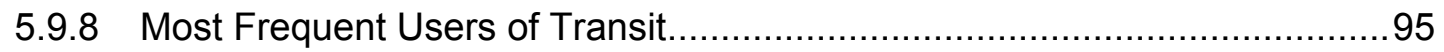

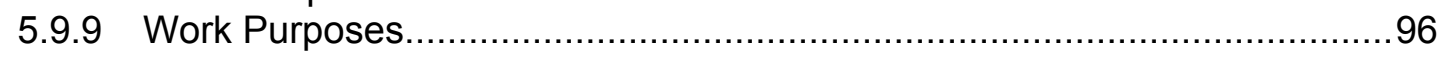

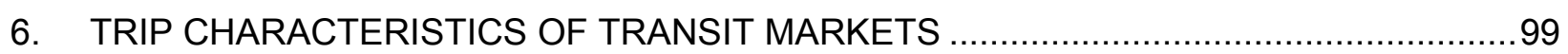

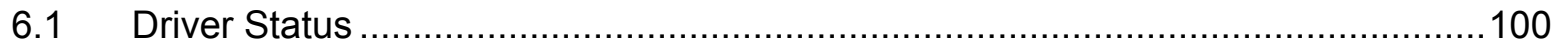

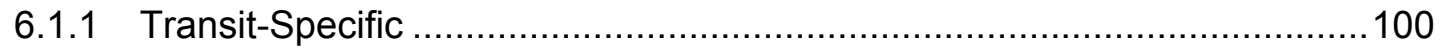

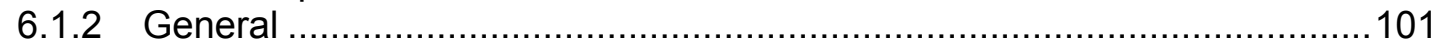

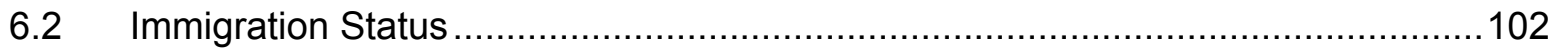

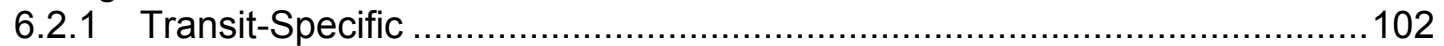

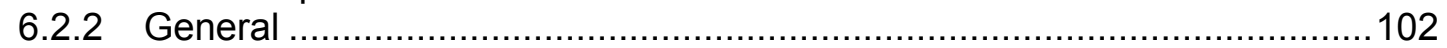

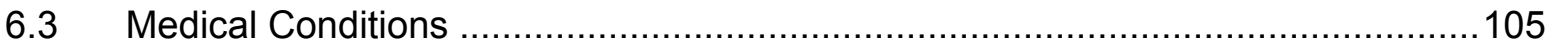

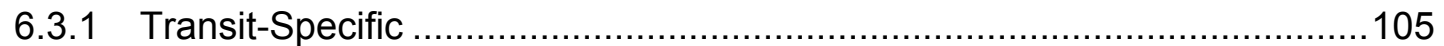

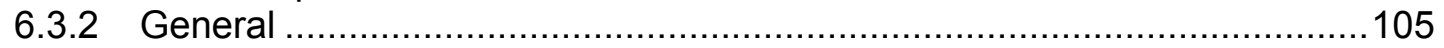

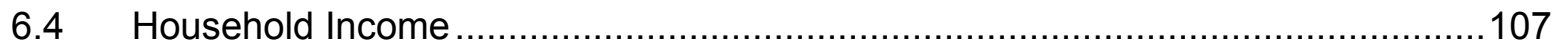

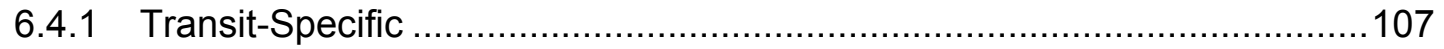

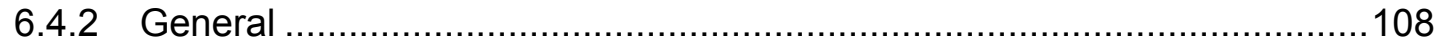

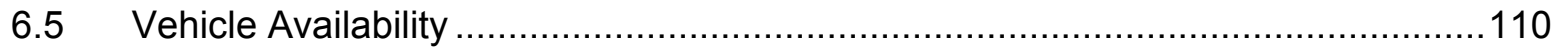

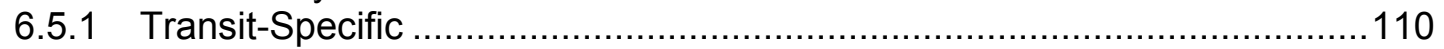

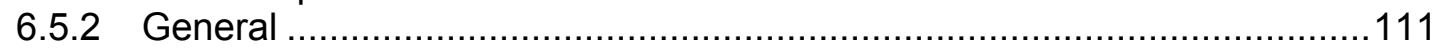

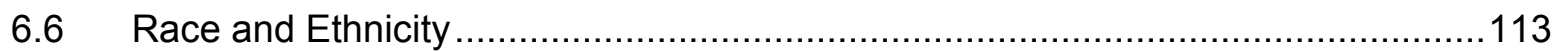

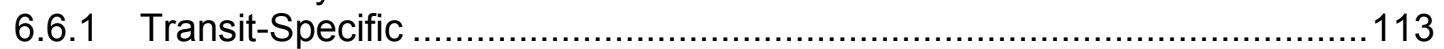

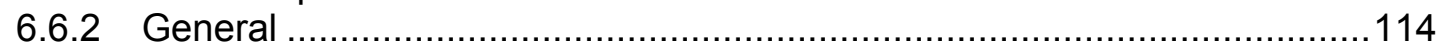

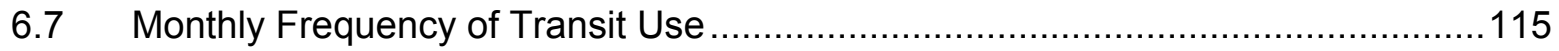

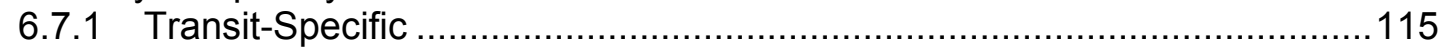

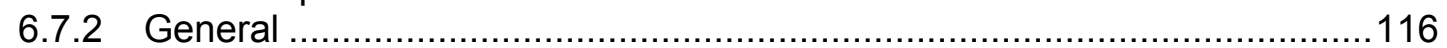

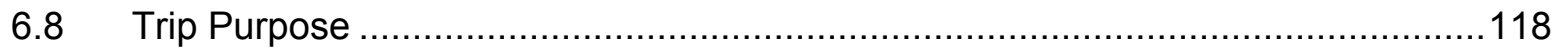

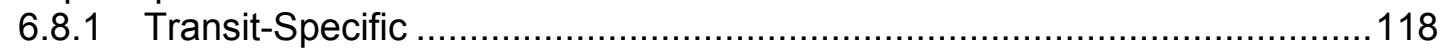

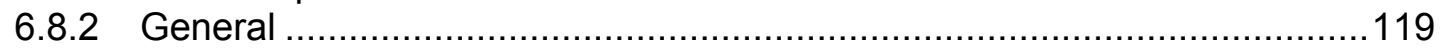

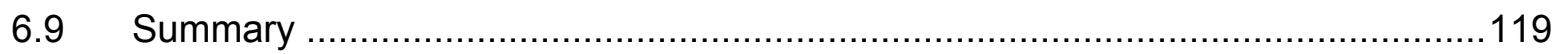

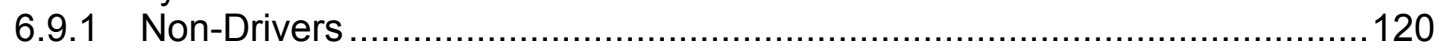

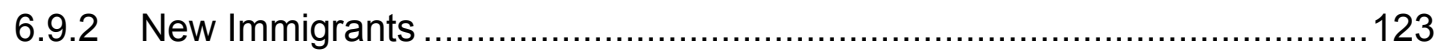

6.9.3 Having Medical Conditions ............................................................... 123

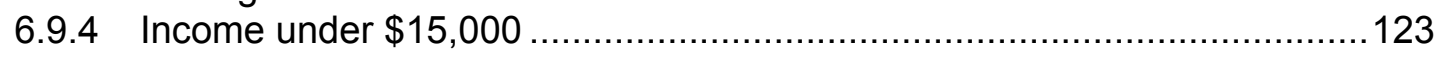

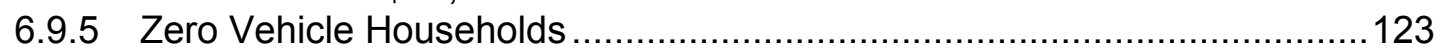

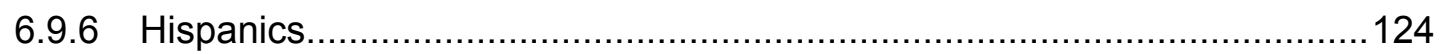

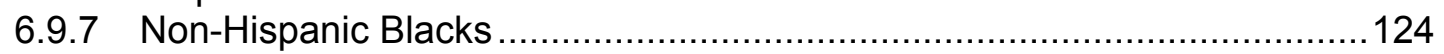

6.9.8 Most Frequent Users................................................................ 124

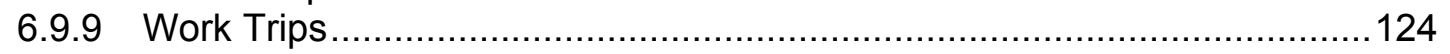

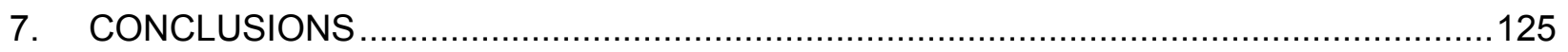

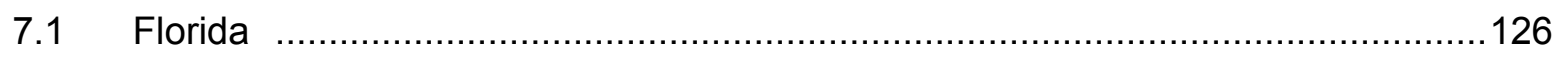

7.2 Market Size and Modal Share for the U.S. ……......................................12 12

7.3 Attitudes of U.S. Travelers and Transit Users..............................................128

7.4 Socio-Demographics of U.S. Transit Markets ..............................................129

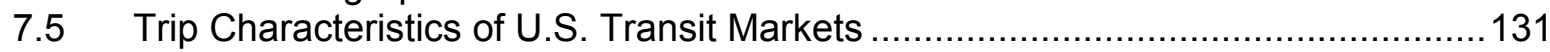

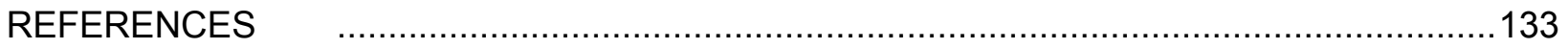




\section{LIST OF FIGURES}

Figure 3.1. Population Distribution by User Status and Service Availability ...................42

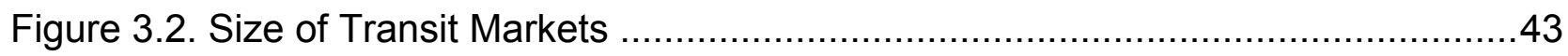

Figure 3.3. Transit's Modal Share within Each Market .............................................. 44

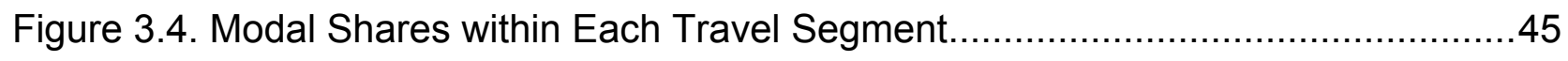

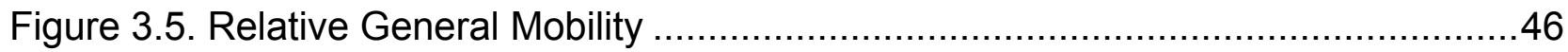

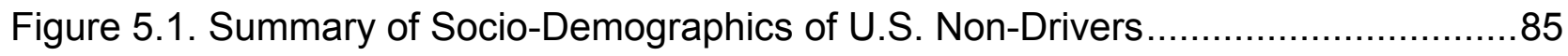

Figure 5.2. Summary of Socio-Demographics of U.S. New Immigrants .........................87

Figure 5.3. Summary of Socio-Demographics of Having Medical Conditions in the U.S..89

Figure 5.4. Summary of Socio-Demographics of Income under $\$ 15,000$ in the U.S. .......90

Figure 5.5. Summary of Socio-Demographics of Zero Vehicle Households in the U.S....91

Figure 5.6. Summary of Socio-Demographics of U.S. Hispanics ..................................93

Figure 5.7. Summary of Socio-Demographics of U.S. Non-Hispanic Blacks .....................94

Figure 5.8. Summary of Socio-Demographics of U.S. Most Frequent Users ...................96

Figure 5.9. Summary of Socio-Demographics of Work Trips for the U.S. .......................97

Figure 7.1. Percent of Transit Trips for Work Purposes by Travel Segment .................132 


\section{LIST OF TABLES}

Table 2.1. Sampling Error of Annual Transit Trips for Selected Population Segments..................8

Table 2.2. Characteristics for Defining Transit Markets .......................................................12

Table 2.3. Criteria for Defining Transit Markets .................................................................13

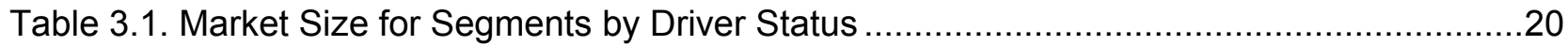

Table 3.2. Modal Share for Segments by Driver Status........................................................22

Table 3.3. Market Size for Segments by Immigration Status .................................................23

Table 3.4. Modal Share for Segments by Immigration Status ............................................25

Table 3.5. Market Size for Segments by Medical Conditions ..............................................26

Table 3.6. Modal Shares for Segments by Medical Conditions .............................................27

Table 3.7. Market Size for Segments by Race and Ethnicity ..............................................28

Table 3.8. Modal Share for Segments by Race and Ethnicity .............................................29

Table 3.9. Market Size for Segments by Household Income ................................................31

Table 3.10. Modal Share for Segments by Household Income ..............................................32

Table 3.11. Market Size for Segments by Vehicle Availability ..............................................34

Table 3.12. Modal Share for Segments by Vehicle Availability ...............................................35

Table 3.13. Market Size for Segments by Frequency of Transit Use .......................................37

Table 3.14. Modal Shares for Segments by Frequency of Transit Use ...................................38

Table 3.15. Market Size for Segments by Trip Purpose ........................................................39

Table 3.16. Modal Shares for Segments by Trip Purpose .....................................................40

Table 4.1. Attitudes by Mode for the U.S. ......................................................................... 48

Table 4.2. Attitudes of Transit Users for Florida and the U.S. .........................................49

Table 4.3. Attitudes of U.S. Transit Markets by Driver Status ................................................51

Table 4.4. Attitudes of U.S. Transit Markets by Immigration Status .......................................52

Table 4.5. Attitudes of U.S. Transit Markets by Medical Conditions ........................................53

Table 4.6. Attitudes of U.S. Transit Markets by Household Income........................................55

Table 4.7. Attitudes of U.S. Transit Markets by Vehicle Availability .......................................56

Table 4.8. Attitudes of U.S. Transit Markets by Race and Ethnicity ........................................57

Table 4.9. Attitudes of U.S. Transit Markets by Frequency of Transit Use ...............................58

Table 4.10. Attitudes of U.S. Transit Markets by Trip Purpose ..............................................59

Table 5.1. Socio-Demographics of U.S. Transit Markets by Driver Status ..............................66

Table 5.2. Socio-Demographics of U.S. Transit Markets by Immigration Status ........................68

Table 5.3. Socio-Demographics of U.S. Transit Markets by Medical Conditions.........................71 
Table 5.4. Socio-Demographics of U.S. Transit Markets by Household Income

Table 5.5. Socio-Demographics of U.S. Transit Markets by Vehicle Availability 75

Table 5.6. Socio-Demographics of U.S. Transit Markets by Race and Ethnicity 78

Table 5.7. Socio-Demographics of U.S. Transit Markets by Frequency of Transit Use. 80

Table 5.8. Socio-Demographics of U.S. Transit Markets by Trip Purpose. 82

Table 6.1. Transit-Specific Characteristics of U.S. Transit Markets by Driver Status 100

Table 6.2. General Characteristics of U.S. Transit Markets by Driver Status 101

Table 6.3. Transit-Specific Characteristics of U.S. Transit Markets by Immigration Status ..... 103

Table 6.4. General Characteristics of U.S. Transit Markets by Immigration Status.... 104

Table 6.5. Transit-Specific Characteristics of U.S. Transit Markets by Medical Conditions.........105

Table 6.6. General Characteristics of U.S. Transit Markets by Medical Conditions....................106

Table 6.7. Transit-Specific Characteristics of U.S. Transit Markets by Household Income .........107

Table 6.8. General Characteristics of U.S. Transit Markets by Household Income .....................109

Table 6.9. Transit-Specific Characteristics of U.S. Transit Markets by Vehicle Availability .........111

Table 6.10. General Characteristics of U.S. Transit Markets by Vehicle Availability ..................112

Table 6.11. Transit-Specific Characteristics of U.S. Transit Markets by Race and Ethnicity .......113

Table 6.12. General Characteristics of U.S. Transit Markets by Race and Ethnicity ..................115

Table 6.13. Transit-Specific Characteristics of U.S. Transit Markets by Frequency of Use........116

Table 6.14. General Characteristics of U.S. Transit Markets by Frequency of Use..................117

Table 6.15. Transit-Specific Characteristics of U.S. Transit Markets by Trip Purpose ...............118

Table 6.16. General Characteristics of U.S. Transit Markets by Trip Purpose ..........................120

Table 6.17. Summary of Transit-Specific Characteristics for Key U.S. Transit Markets ..............121

Table 6.18. Summary of General Characteristics for Key U.S. Transit Markets ........................122

Table 7.1. Spatial Pattern of Transit Markets by Immigrant Status.......................................129 


\section{INTRODUCTION}

This study assesses a range of public transit markets for the benefit of not only operating agencies but also policy bodies and funding agencies. For operating agencies, the primary objective is to increase ridership through effective strategic planning, marketing, and good service design. For policy bodies and funding agencies, the primary objective is to accomplish public policy objectives, including improving the condition of transportation systems and the well-being of population segments that are disadvantaged for transportation and economic conditions. For both purposes, a current and good understanding of transit markets is critical.

Through "A Profile of Public Transportation Passenger Demographics and Travel Characteristics Reported in On-Board Surveys," the American Public Transportation Association (APTA) in 2007 assessed a range of public transit markets. The assessment was based on a compilation of tabulated data from 150 transit on-board surveys collected during the period from 2000 through 2005 by a variety of operating agencies throughout the country. Data from a transit on-board survey in general are collected from passengers while they are on-board transit vehicles in revenue service. This assessment defined several markets for each of 15 demographic and travel characteristics of transit riders; for the demographic characteristic of household income, for example, the assessment defined seven markets. While this represents the recent effort at the national level to examine a range of public transit markets, it is limited to the relative sizes of individual transit markets in percentage terms for all transit modes combined, for rail, and for bus. Besides knowing that these income-based markets differ in household income, this assessment provides little information beyond the fact that these income-based markets capture different shares of the total transit market, the total rail market, and the total bus market.

The current study also assesses the size of a wide range of public transit markets. These markets are based on trip purpose and a set of seven personal, household, and travel characteristics, including driver status, immigration status, existence of medical conditions, household income, vehicle availability, race and ethnicity, and monthly frequency of transit use. These characteristics are often examined in relation to transit travel, for example, in APTA's 2007 report titled "A Profile of Public Transportation Passenger Demographics and Travel Characteristics Reported in On-Board Surveys" and the Center for Urban Transportation Research's (CUTR) 2005 report titled "Public Transit in America: Results from the 2001 National Household Travel Survey." The section on data and methodology details how these transit markets are defined using these characteristics.

More important, this study goes far beyond what the APTA study accomplished, including the following:

1. For the set of market segments based on each characteristic, it determines their market sizes for public transit by looking at how all transit trips are distributed across these market 
segments. In addition, their market sizes are compared between transit and each of other major modes, including driving, riding in a privately-operated vehicle (POV), walking, and biking. The data on market size for a given mode provides an indicator of the importance of each market relative to other markets for this mode.

2. For the set of market segments based on each characteristic, it determines their population sizes by looking at how the total population is distributed across these market segments and compares population size with market size of travel by each mode and all modes combined. This comparison indicates how much persons in a given segment travel relative to the average person in the total population.

3. For the set of market segments based on each characteristic, it compares their market sizes for transit and each other mode between Florida and the U.S. as a whole.

4. It determines how all person-trips by each market segment distribute across transit and other modes and compares this modal distribution across the set of market segments based on each characteristic. The data on modal share indicates how large a role transit and each other major mode play in serving each market segment.

5. It compares attitudes of transit users against users of each other major mode, including driving, riding in a POV, walking, and biking.

6. It compares attitudes of transit users between Florida and the U.S. as a whole.

7. It compares attitudes of transit users across the market segments based on each characteristic.

8. It assesses the socio-demographics of each transit market, i.e., the distribution of transit trips within each transit market across the population segments defined on the basis of each of 10 socio-demographic characteristics of its population.

9. It assesses the trip characteristics of each transit market, including both transit-specific and general characteristics.

Unlike the APTA study, the current study uses data from the 2009 National Household Travel Survey (NHTS). Since 1969, the NHTS series has been the only authoritative source of the nation's inventory of household travel, including transit and other means of transportation and a host of other trip-making characteristics. The latest NHTS provides a unique opportunity for gaining insights into public transit markets in Florida and the U.S. Its design and development were based on a rigorous statistical process. It contains significantly more data than previous surveys and 
allows richer and statistically more meaningful assessment of transit markets. Specifically, it has a large sample size of 150,149 households for the U.S., including 15,884 households for Florida.

While modal markets are important considerations in the APTA study, the current study avoids defining transit markets based on different transit modes (e.g., rail and bus). As discussed more in the section on data and methodology, linked trips are the unit of data collection in the 2009 NHTS. That is, data on trip characteristics were collected for the entire trip from its origin to its destination. In contrast, the primary unit of data collection from on-board surveys is unlinked trips. While the 2009 NHTS did collect some information on access and egress modes, that information is extremely limited relative to what is available for the entire linked trip. When transit is the main mode of a linked trip, more than one unlinked trip by the same transit mode or more than one unlinked trip by multiple transit modes are used. With the limited information on access and egress modes, these unlinked trips in the same linked trip cannot be meaningfully separated. As a result, defining transit markets by mode is not particularly meaningful.

The assessment of public transit markets in the current study serves the purposes relevant mostly for policy bodies and funding agencies. For these policy bodies and funding agencies, the need for understanding transit markets is generally at the aggregated level. They use the information on transit markets for better policy and funding decisions. In contrast, the need for operating agencies is generally at geographically-disaggregated levels. At the regional level, good information on transit markets can help operating agencies better conduct strategic planning and marketing efforts. At a more local level, good information on transit markets can help operating agencies better design and provide their services. Operating agencies can still find the assessment of transit markets at aggregated geographic levels useful in that they can use it as a benchmark against which their own transit markets may be compared.

This assessment can also provide critical information for a complete picture of various transit markets. In addition to their current conditions as reflected in the characteristics of these markets in the current study, the complete picture would also include a historical look and a futuristic look at them-how they have changed over time and how they would continue to change in the future. Getting the complete picture would provide a better understanding of the needs of various markets and determine how governments should respond in terms of funding, types of service, transit technologies, etc.

The remainder of this report is organized into six sections. Section 2 describes the data and methods used for market assessment. Section 3 describes the size and modal shares of the transit markets for both Florida and the U.S. Section 4 assesses the transit markets by their attitudes towards transit and other transportation issues for both Florida and the U.S. Section 5 assesses the socio-demographics of these transit markets for the U.S. only. Section 6 assesses the travel characteristics of these transit markets for the U.S. only. Section 7 highlights some of the results from the current study. 


\section{DATA AND METHODOLOGY}

This section describes the data source and methodology used for defining and assessing transit markets. The datasets from the 2009 NHTS are the source of data for assessment. The description of the data focuses on the content and quality of the data that are relevant for this study. The methodology is discussed in terms of several of its aspects, including definition of transit markets, assessment strategy, and interpretation of the results.

\subsection{Data}

\subsubsection{NHTS Sample}

The 2009 NHTS contains a large sample size of 150,147 households for the U.S., including 15,884 households for Florida. It collected data from a given sample household on all travel made in a 24hour period (i.e., the designated travel day for this household) by persons 5 years of age or older for all purposes by all means of transportation. The sampled households cover all areas of the U.S., both urban and rural, and the designated travel day for different sampled households varies throughout the 13-month period from April 2008 to April 2009. Detailed trip data were collected through telephone interviews on the basis of pre-mailed travel diaries. The data include weights to expand the sample to annual totals. Details about this survey and the datasets from it can be found at the official NHTS website of the Federal Highway Administration (FHWA 2012).

\subsubsection{Data Content}

The 2009 NHTS collected data on the one-way trips that the sampled persons and households took on their designated travel days. A one-way trip is defined as any time a subject went from one address to another for purposes other than changing the mode. Any one-way trip is a linked trip from its origin to its destination for any mode, particularly for transit. A one-way trip is frequently referred to as a person-trip in this study.

The 2009 NHTS collected data on many characteristics for each one-way trip in the survey: trip distance, trip duration, trip purpose, and the modes of transportation, among other things. A total of 24 specific modes are recognized in the survey. If more than one mode is used on a one-way trip, the mode that covered the most distance is designated as the main mode for that trip.

A transit trip is a person-trip whose main mode is transit. For this study, transit consists of any of the following fixed-route modes identified in the 2009 NHTS: local public bus, commuter bus, commuter train, subway or elevated train, and street car or trolley. The 2009 NHTS explicitly includes special transit for people with disabilities, which had not been used previously in the NHTS series. The current study does not include this new mode as part of its definition of public transit; the datasets from the 2009 NHTS do not recognize it as public transit in some of the derived variables on transit. The data for transit trips include wait time for transit vehicles. If a transit trip 
involves more than one boarding, it is unclear from the survey documents whether the wait time is for the first boarding only or for all boardings. The data for transit trips also include information on the specific mode for each of up to five access segments and on the specific mode for each of up to five egress segments. However, the data do not include the access or egress duration for each access or egress segment; rather, they include only the combined total access time for all access segments and the combined total egress time for all egress segments. For any transit trip, it is unclear from the survey documents whether its main mode portion contains a single boarding or may contain multiple boardings with the same transit mode.

The 2009 NHTS also collected data on the personal, household, and location characteristics of the persons and households in the sample. Relevant to the current study are person age; whether a person was a driver; whether a person was an immigrant and, if so, when he entered the U.S.; and whether the person had any medical conditions that made it difficult to travel outside of the home. It also contains data on many household characteristics. Relevant to the current study are annual household income, vehicles available for use by household members, race and ethnicity, and where a household is located in terms of housing density and whether it is in an urbanized area. It is noted that locational information on housing density and urbanized areas is outdated because it is based on data from the 2000 Census.

The 2009 NHTS collected data on general travel habits of the persons in the sample. These include monthly frequency of transit use during the month immediately before the travel day and weekly frequency of walking and biking. Further, data were collected on the attitudes of the sampled persons towards transportation issues in terms of their choice of the most important issue among a set of six pre-specified issues and their view on the seriousness of each issue.

\subsubsection{Data Quality}

Just like any data obtained through a probability-based sample, the data presented in this study contain at least two types of errors: sampling and non-sampling.

Since the 2009 NHTS collected data from a sample rather than the census of all households, all persons, and all travel they made during the data period, the data presented may differ from those that would have been obtained if a census were conducted under the exact same circumstances. The size of sampling error depends largely on the size of the sample, i.e., the number of households and the number of persons in each sampled household in the final sample. Since the sample size becomes smaller as one moves to smaller geographies from the national level or to smaller population segments at a given geography, sampling error in data for a given characteristic in general is smallest at the national level and at the full population level for a given geography and is larger as one moves to smaller geographies or smaller population segments at a given geography. More is discussed on sampling error and different sub-samples from the 2009 NHTS later in this section. 
In addition to sampling error, errors can also result from many potential non-sampling sources. These sources include human mistakes, non-responses, and under-coverage. Non-sampling error from human mistakes in the 2009 NHTS includes, for example, a respondent misunderstanding a question and answering it incorrectly; a respondent not recalling a trip or remembering details of the trip incorrectly; and an interviewer not correctly recording what the respondent said. Examples of non-sampling error from non-responses include a person or household that was a non-respondent and a person not answering a specific question. Under-coverage occurs when not all households are considered in drawing the sample. Reasons for under-coverage in the case of the 2009 NHTS include a household having no telephone; a person stating incorrectly that the telephone number the surveyors had dialed was not residential; and the household respondent either accidentally or purposely not reporting all of the people living in the household.

For the 2009 NHTS, good estimates of sampling error are possible, but it is impossible to estimate non-sampling error. For any given data item presented in the current study, its sampling error may be obtained in one of three mechanisms:

- Using the Table Designer at the official NHTS site at http://nhts.ornl.gov/tools.shtml.

- Using the following formula for readers who use only those software packages (e.g., SPSS) that cannot correctly account for the complex design of the 2009 NHTS sample:

$$
\sqrt{\frac{99}{100} \sum_{i=1}^{100}[R E P(i)-x]^{2}}
$$

where $x$ is what one gets from using the original sample weights and $R E P(i)$ is what one gets from using the $i^{\text {th }}$ of the 100 sets of replicate weights. When using the Travel Day file, for example, the weight WTTRDFIN is used to get $x$, while the weight WTTRDFIN1 is used to get $R E P(1)$, the weight WTTRDFIN2 is used to get $R E P(2)$, etc. This would be tedious, of course, because the same calculation needs to be made 101 times, using the original weights and the 100 sets of replicate weights, respectively.

- Using software packages that can correctly account for the complex design of the 2009 NHTS sample. Once the corresponding replicate weights are provided, these packages can automatically estimate sampling error. One commercially-available package is SUDAAN and a free package is WesVar.

This report does not show sampling error for presentational reasons. Showing sampling error along with the data of interest would not be an issue for presentation if the amount of data of interest were limited. In this report, however, a large amount of data of interest is presented, making it 
impractical to show their sampling error as well. Showing their sampling error simply means doubling the number of columns or the number of rows for data presented in a table format.

To avoid presenting data whose sampling error is unreasonably large, the current study avoids presenting data that result from small samples. This is accomplished by limiting the analyses to the U.S. as a whole or to large sub-nation geographies, by limiting the analyses to a small number of population segments at these large geographies for any given characteristic considered, and by choosing break points between population segments so that each segment has an adequate portion of the sample.

Instead, estimates of sampling error are presented for a few data items to give the reader a direct appreciation of the likely size of sampling error for the various transit markets presented in this report. Table 2.1 shows the sampling error of the annual number of transit trips estimated from the 2009 NHTS for five population segments, ranging from the full U.S. population to the U.S. population segments by vehicle availability and driver status, as well as to the full Florida population. For each segment, the table shows its sample size in the number of linked transit trips, the estimated number of transit trips, and three measures of sampling error. These measures include the $95 \%$ margin of error, standard error, and coefficient of variation (COV). The $95 \%$ margin of error for an estimate measures one half of the length of its $95 \%$ confidence interval. The COV indicates the size of sampling error relative to the estimated number of trips in percentage terms.

Table 2.1. Sampling Error of Annual Transit Trips for Selected Population Segments

\begin{tabular}{|l|c|c|c|c|c|}
\hline Population Segments & $\begin{array}{c}\text { Sample } \\
\text { Size }\end{array}$ & $\begin{array}{c}\text { Estimated } \\
\text { Transit } \\
\text { Trips } \\
\text { (millions) }\end{array}$ & $\begin{array}{c}\text { 95\% } \\
\text { Margin of } \\
\text { Error } \\
\text { (millions) }\end{array}$ & $\begin{array}{c}\text { Standard } \\
\text { Error } \\
\text { (millions) }\end{array}$ & $\begin{array}{c}\text { Coefficient } \\
\text { of Variation } \\
\text { (COV) }\end{array}$ \\
\hline U.S. total & 8,521 & 7,520 & 493.4 & 251.7 & $3.3 \%$ \\
U.S. zero-vehicle households & 3,532 & 3,612 & 371.7 & 189.6 & $3.5 \%$ \\
U.S. non-drivers & 910 & 922 & 200.7 & 102.4 & $11.1 \%$ \\
U.S. non-drivers in zero-vehicle households & 520 & 541 & 174.6 & 89.1 & $16.5 \%$ \\
Florida total & 513 & 228 & 55.5 & 28.3 & $12.4 \%$ \\
\hline
\end{tabular}

Source: Data on sample size, estimated transit trips, and 95\% margin of error are from Table Designer at the official NHTS website. Standard error $=95 \%$ margin of error $/ 1.96$. Coefficient of variation $=100 *$ (standard error / estimated transit trips). Except for some of the numbers in this table, all other numerical results in this report have been estimated by the author using the datasets from the 2009 NHTS.

Either $95 \%$ margin of error or standard error may be used for effectively indicating the variability of a single estimate. One way to do this would be to construct the commonly-used confidence interval at certain confidence level. For comparing the degree of variability in estimates obtained from survey data across different population segments, margin of error or standard error is not effective, however, because they depend on the magnitude of the estimates as well. COV is normalized by the magnitude of the estimates and is more effective for such comparisons. 
The COV is 3.3 percent for the full U.S. population, indicating that the standard error for the estimated number of transit trips for the U.S. as a whole is 3.3 percent of the estimate. The COV is only slightly higher at 3.5 percent for all transit trips made by persons in zero-vehicle households, although the sample is smaller than one half of the full U.S. sample. But the COV is much higher at 11.1 percent for non-drivers and even higher at 16.5 percent for non-drivers in zero-vehicle households. The COV for the full Florida sample is 12.4 percent, lower than that for non-drivers in zero-vehicle households for the U.S. as a whole, although the Florida full sample is smaller.

\subsection{Methodology}

The basic methodology of the current study for assessing transit markets consists of three elements. The first focuses on the definition of a range of transit markets on the basis of a set of sociodemographic and travel characteristics of transit users. The second focuses on assessing these transit markets from a range of perspectives. The third is the use of cross tabulations for this assessment. This section describes the first two elements and discusses several other aspects of the overall methodology, including separate analysis for Florida for some of the assessment perspectives when data permit for statistical reasons and proper interpretation of the results from the current study.

\subsubsection{Defining Market Segments}

This section discusses how the current study defines the market segments for assessment, including the general approach, the selection of characteristics on which these market segments are defined, and the definition of specific market segments for each of the selected characteristics.

\section{General Approach}

The objective of defining market segments differs between meeting the need of operating agencies and meeting the need of policy bodies and funding agencies. For operating agencies, the ultimate goal is to increase ridership with a given operating budget. For them, the objective of defining market segments is to reach a point where the responses of one segment differ from those of other segments to certain marketing campaigns or service changes. For policy bodies and funding agencies, on the other hand, the ultimate goal is to improve the overall transportation system (e.g., congestion relief), improve the well-being of those persons who are either transportation disadvantaged or economically disadvantaged, etc. Their objective of defining market segments is for those market segments that are of policy and funding interest forming their own groups (e.g., low income, persons with medical conditions, etc.).

There are three commonly-used bases on which market segments may be defined: sociodemographic characteristics, product usage (e.g., frequency of transit use, trip purpose), and user attitudes. The assessment in the current study is based on all three. While some data on attitudes are available for the full sample in the 2009 NHTS, they are not rich enough for defining market segments. Instead, the data on attitudes are used as characteristics of the market segments. The 
assessment in the current study uses socio-demographics as the basis for defining most of the market segments and uses product usage as the basis for defining other market segments.

For a given basis, different approaches may be used for defining market segments, and their complexity and data requirements vary significantly. The simplest approach would use a single socio-demographic (e.g., household income) as the basis and split the whole population into two or more population groups based on the chosen characteristic. If household income is used as the basis, for example, the resulting market segments might be low income, middle income, and high income. The exact income break points for separating these three population segments would need to be selected based on other considerations. This simple approach is more commonly used by policy bodies and funding agencies. However, operating agencies also use this simple approach to examine their customers using data collected from transit on-board surveys. The assessment in the current study uses this simple approach, although in some cases the basis for defining market segments consists of more than one socio-demographic characteristic. One example is the market segments based on vehicle availability, which are based on a comparison between the number of vehicles and the number of workers in a household.

More complex approaches would use a large amount of information and sophisticated statistical methods. One statistical method commonly used for these complex approaches is factor analysis, which involves a statistical procedure to transform a large number of possibly correlated variables into a smaller group of uncorrelated variables called factors. These factors are then used in defining market segments. Another statistical method often used is structural equation modeling, which is a statistical procedure to establish links between the factors from a factor analysis to sociodemographic data, allowing the market segments defined using the factors be located within a region. Operating agencies may find these complex approaches more useful for their marketing efforts and service design.

The above discussion and the general approach taken in the current study to defining market segments are based on a review of the literature on defining and analyzing transit markets both at the local level and at the national level, including the following:

- TCRP Report 28, "Transit Markets of the Future-The Challenge of Change" (Rosebloom 1998) identifies current demographics, economic conditions, social, land use, and public policy trends and transit markets and assesses how these trends are likely to influence these current trends; identifies potential future trends and assesses how these future trends may create new transit markets; suggests potential service options to meet these changing current markets and potential new markets.

- TCRP Report 36, "A Handbook: Using Market Segmentation to Increase Transit Ridership" (Elmore-Yalch 1998) provides steps and procedures for marketers or market researchers to implement a market segmentation program within transit agencies. 
- TCRP Report 37, "A Handbook: Integrating Market Research into Transit Management" (Elmore-Yalch 1998) evaluates market research strategies appropriate for transit and provides guidance to transit management for integrating and institutionalizing market research into decision-making processes of transit agencies.

- Brendon Hemily, "Trends Affecting Public Transit's Effectiveness: A Review and Proposed Actions" (APTA 2004) reviews a wide range of medium- to longer-term trends on land use and mobility patterns, societal changes and concerns, emerging professional practices in urban planning, etc.; distills the challenges these trends create for the transit industry; and identifies four market segments from these trends: commuters, immigrants, the aging population, and persons with disabilities and economically disadvantaged.

- Cambridge Systematics, "Transit Market Research Models" (Washington State Department of Transportation 2009) provides a set of advanced models for identifying market segments at the local level.

\section{Defining Characteristics}

The current study uses six socio-demographic characteristics and two travel characteristics to define market segments. The socio-demographic characteristics are driver status, immigration status, existence of medical conditions, household income, vehicle availability, and race and ethnicity. The travel characteristics are monthly frequency of transit use and the purpose of persontrips on the travel day. These characteristics for defining the market segments result from several considerations:

- Those that are typically present in transit on-board surveys and related profiles of transit riders. One good source of such information would be the reports on Transit Performance Monitoring Systems (McCollom Management Consulting 2002 and 2004) and APTA's most recent report on ridership profiles (APTA 2007).

- Those that are highly relevant for policy makers and funding agencies. Some of these relate to persons with transportation and economic disadvantages (e.g., non-drivers, persons with medical conditions, low income, zero vehicles); some relate to traffic management (e.g., trips for work purposes); and others relate to necessary travel for sustaining daily life (e.g., medical trips).

- Those that have been shown to have large differences in transit's modal share across the relevant market segments as reported in the previous reports on public transit in America (e.g., Hispanics, blacks). 
- Those that are highly relevant to the frequent discussions about occasional users, infrequent users, and frequent users (e.g., monthly frequency of transit use).

Table 2.2 summarizes these characteristics. Most fall under more than one consideration. The following are noted about what some of these characteristics may measure:

- A driver in the 2009 NHTS does not necessarily have a legal driver's license. Whether someone was a driver is determined in one of three ways: 1) that person was listed as a driver in general; 2) that person drove on the travel day; or 3) that person was a primary driver of any household vehicle.

- A medical condition here refers to a temporary or permanent condition or disability that makes it difficult to travel outside of the home. Like many other concepts, the 2009 NHTS did not define what may be considered "difficult"; it was up to the interpretation of the respondents.

- Transit implied by the monthly frequency of transit use likely differs from what is defined from individual modes in the current study. While the component modes are largely consistent with the definition of public transit, what constitutes one use of transit is up to the interpretation of individual respondents. The survey question was about how often public transit was used rather than about how many linked trips were made using public transit as the main mode. The survey question is: "In the past month, about how often have you used public transportation such as buses, subways, streetcars, or commuter trains?"

Table 2.2. Characteristics for Defining Transit Markets

\begin{tabular}{|l|l|l|}
\hline \multicolumn{2}{|l|}{ Characteristics } & \multicolumn{1}{c|}{ Description } \\
\hline \multirow{4}{*}{ Personal } & Driver status & Whether one is at least 15 years old and, if so, whether one is a driver \\
\cline { 2 - 3 } & Immigration status & Whether one is an immigrant and, if so, year entered the U.S. \\
\cline { 2 - 3 } & $\begin{array}{l}\text { Existence of medical } \\
\text { conditions }\end{array}$ & $\begin{array}{l}\text { Whether one has a condition or disability that makes it difficult to } \\
\text { travel outside of the home }\end{array}$ \\
\hline \multirow{3}{*}{ Household } & Household income & Ranges of annual household income \\
\cline { 2 - 3 } & Vehicle availability & Number of vehicles for household use relative to number of workers \\
\cline { 2 - 3 } Travel & Race and ethnicity & Race and ethnicity of the householder \\
\cline { 2 - 3 } & Frequency of transit use & Monthly number of times a person used transit \\
\cline { 2 - 3 } & Trip purpose & Purpose of individual person-trips on the travel day \\
\hline
\end{tabular}

\section{Defining Criteria}

For each characteristic selected above, two to four market segments are defined. Table 2.3 summarizes the resulting segments. The market segments for each characteristic are defined with three considerations: using knowledge from the literature about differences in transit use, differences in policy concerns across these segments, and adequate sample size for each 
segment. The definition for some of these is clear, but the definition for others needs some clarification:

- Driver Status - Three segments are defined: drivers, non-drivers, and children (persons under 15 years of age) who are too young to drive in 41 states. Nine states either allow all 14-year-old persons (Alaska, Arkansas, lowa, Kansas, South Dakota, and North Dakota) or allow persons age 14 years 6 months or 14 years 9 months (Idaho, Michigan, and Montana) to get a learner's permit (http://www.ghsa.org/html/stateinfo/laws/license_laws.html).

- Immigrant Status - Traditionally, immigrants are thought to merge into the U.S. society quickly and to behave notably differently from the rest of the population only during the first few years after the first time they entered the U.S. To study each travel segment, however, each needs to have sufficient sample size. As a result, a 10-year period is used to define the segment for new immigrants.

- Frequency of Usage - Non-users are persons who did not use transit at all during the month immediately before their travel day. Many of them did not use transit on their travel day, either, but some may have used it on their travel day. These persons use transit less than once per month and are referred to as occasional users of transit. Persons in the other three markets use transit at least once per month and are referred to as regular users of transit. Our focus is on regular users.

Table 2.3. Criteria for Defining Transit Markets

\begin{tabular}{|l|l|l|l|l|l|}
\hline \multicolumn{2}{|c|}{ Characteristics } & \multicolumn{4}{c|}{ Criteria } \\
\cline { 3 - 6 } & \multicolumn{1}{|c|}{ Segment 1 } & \multicolumn{1}{c|}{ Segment 2 } & \multicolumn{1}{c|}{ Segment 3 } & Segment 4 \\
\hline \multirow{3}{*}{ Personal } & Driver status & Children & Drivers & Non-drivers & \\
\cline { 2 - 6 } & Immigration status & New immigrants & Older immigrants & Non-immigrants & \\
\cline { 2 - 7 } & Medical conditions & With conditions & No conditions & & $\$ 100,000+$ \\
\hline \multirow{3}{*}{ Household } & Household income & Under \$15,000 & $\$ 15,000-\$ 49,999$ & $\$ 50,000-\$ 99,999$ & \\
\cline { 2 - 7 } & Vehicle availability & Zero vehicles & Vehicles < workers & Vehicles $\geq$ workers & Non-Hispanic Others \\
\cline { 2 - 7 } Travel & Race and ethnicity & Hispanics & Non-Hispanic Whites & Non-Hispanic Blacks & Non-users \\
\hline
\end{tabular}

\subsubsection{Assessment Strategy}

The basic strategy of the current study is to assess these markets from a range of perspectives. The results from different assessment perspectives may serve different purposes. Even when serving the same purpose, results from multiple perspectives may give a fuller picture and a better understanding of a market. The assessment includes five perspectives: market size, modal shares, attitudes, socio-demographics, and trip characteristics. 


\section{Market Size}

This perspective determines the size of market segments for transit and each other major mode in percentage terms. Consider the four income-based segments as an example: how are all transit trips by the entire population distributed across these segments? Similarly, how are all walk trips by the entire population distributed across the four income-based segments? The data on market size for a given mode provides an indicator of the importance of each market relative to other markets for this mode. These results would answer questions such as: What percent of transit trips are made for work purposes? When compared with population size for the same markets, the data on market size provides information on how much transit is used by persons in a given segment relative to the average person in the total population. If non-drivers make 20 percent of all transit trips but represent only 10 percent of the total population, for example, one can determine that they use transit twice as much as the average person in the total population.

\section{Modal Shares}

This perspective determines the modal shares of all person-trips across major modes, including transit for each market segment. The data on modal share provides an indicator of how large a role transit plays in serving each market. These results would answer questions such as this: What percent of travel for work purposes is served by transit and each of the other modes?

\section{Attitudes}

This perspective examines the attitudes of each transit market towards a set of transportation issues. Note that the term "transit market" is used here instead of "market segment," used in the previous two paragraphs. This is because the analysis for this perspective and the next two perspectives focuses on transit trips only, while the analysis for the previous two perspectives includes travel by other modes as well. The data on these attitudes came from two questions in the 2009 NHTS. One asked the respondents to choose the most important issue among a list of six pre-identified transportation issues. These include:

- Highway congestion

- Access to and availability of transit

- Lack of walkways and sidewalks

- Price of travel

- Aggressive and distracted drivers

- Safety concerns

The second question asked the respondents to indicate the level of seriousness for each of these issues. There were three levels for the seriousness of an issue:

- A little issue

- A moderate issue

- A big issue 


\section{Socio-Demographics}

This perspective determines the socio-demographics of transit markets. In addition to the eight socio-demographic and travel characteristics used to define market segments, this perspective also considers person age and two location characteristics: housing density at the census tract level and whether a household is located in an urbanized area and, if so, its population size. The data on the socio-demographics of transit markets tells who the transit trip makers are in each market. Consider the most frequent users of transit (i.e., use transit 30+ times per month): Who are they? Are they mostly non-drivers? Do they mostly live in zero-vehicle households or in households with extremely low income? Where do they live? Do they live mostly in high-density areas? Do they use transit mostly for work purposes?

\section{Trip Characteristics}

This perspective determines the trip characteristics of each transit market. Both a set of general characteristics and a set of transit-specific characteristics are considered. The general characteristics include day of week, time of day, trip purpose, distance, duration, and speed. The transit-specific characteristics include wait time, last access mode to the main mode, first egress mode from the main mode, total access time, and total egress time. Consider the trip purpose characteristic for income-based market segments; the data from this perspective may be used to answer the question, How does the share of work trips served by transit vary by household income?

\subsubsection{Separate Analysis for Florida}

Assessments were conducted for Florida to provide information to the Florida Department of Transportation (FDOT), which funded this study through the National Center for Transit Research at the University of South Florida. To avoid results with large sampling error, the separate analyses for Florida are limited to the following perspectives:

- Size of travel markets by each major mode, including transit

- Modal shares of travel markets across major modes, including transit

- Attitudes towards transportation issues

It is noted that sampling for the 2009 NHTS was based on residential housing units and whether these units had landline phone service. As a result, temporary residents who happened to be living in their Florida home during the survey period may be included in the sample. Similarly, permanent residents of Florida who happened to be living in another state as temporary residents during the survey period for Florida were not included in the Florida sample. 


\subsubsection{Interpretation of Results}

\section{Description}

The data presented and relationships implied in these data are meant to be interpreted descriptively rather than causally. If the presented data indicate that transit's modal share at a given geography is 20 percent for persons who live in households with annual income under $\$ 15,000$ and 1 percent for persons who live in households with annual income over $\$ 100,000$, one should not attribute this difference solely to the difference in household income. The report may not present any other data that can help determine the exact causes of this difference in transit's modal share. By presenting these two sets of numbers, this report simply indicates that these two market segments differ and that they differ to a certain numerical degree. If causes are to be considered, the difference in household income is most likely just one of many possible causes. Other causes exist because persons in these two market segments differ in many other ways, including where they live, for example.

\section{Trip-Maker Characteristics}

For personal, household, location, and attitude characteristics, the data presented represent the characteristics of the trip makers rather than the persons. When presenting data on the characteristics of the trip makers, those persons who make four times as many trips as others have four times the influence on the data presented than others. When presenting data on the characteristics of the persons involved, their amount of travel does not play a role in the data presented.

This consideration is similar to the case where rider characteristics differ from user characteristics. Transit on-board surveys typically are designed to capture repeated boardings by the same transit user. As a result, a direct analysis of the data from such an on-board survey results in information about riders rather than persons who use transit. Persons who board transit four times as often as others have four times the influence on the data on rider characteristics than others. As an example, the information presented in APTA's "A Profile of Public Transportation Passenger Demographic and Travel Characteristics" represents rider characteristics. The difference between the current report and rider characteristics from typical on-board surveys is that the unit of travel is in linked person-trips in this report, while it is in boardings in the case of on-board surveys.

Results from this trip-maker approach are believed to be more relevant for operating agencies as well as policy bodies and funding agencies than those from a user approach. However, this tripmaker approach also makes it somewhat more complex to interpret the results. Consider the following example. Suppose that Hispanics make 50 percent of the transit trips taken by nondrivers, but they make 25 percent of the transit trips taken by drivers. What differences between Hispanic drivers and Hispanic non-drivers result in this large difference in their share of the respective transit markets? We do not know the exact reasons for this difference, but we do know that any difference in how much these two groups of Hispanics use transit plays a role. 


\subsubsection{Terminology}

This report frequently uses four terms that refer to different things in most cases, but two are used interchangeably. These four terms are "travel segment," "transit market," and "population segment," and "market segment." Both "travel market" and "transit market" are related to trip making; "transit market" is used when the focus is on transit trips and their distribution across population segments, and "travel market" is used when the discussion deals broadly with trip making by all modes and its distribution across population segments. "Population segment" refers solely to population and is used when the discussion does not relate to the distribution of trip making by any mode. "Market segment" is used for both cases. "Market segment" and "travel market" are sometimes used interchangeably. 


\section{SIZE AND MODAL SHARES OF MARKET SEGMENTS}

This section puts travel by transit in the perspective of travel by all other modes from two angles:

- Market Size - This looks at the distribution of all travel by transit and each other major mode across the set of travel markets based on a given characteristic. Consider income-based market segments: how are all transit trips by the entire population distributed across the four income-based segments? The data on market size for a given mode provides an indicator of the importance of each market relative to other markets for this mode. These results would answer questions such as, What share of the entire transit market is captured by persons in zero-vehicle households?

- Modal Share - This looks at how all person-trips by each market segment distribute across transit and other modes. The data on modal share indicates how large a role transit and each other major mode play in serving each segment. These results would answer questions such as, what percent of work trips by non-drivers is served by transit? What other modes do non-drivers use most when they do not use transit?

For comparison, population size of the market segments also is presented. When compared with population size, the data on market size provides information on how much transit is used by persons in a given segment relative to the average person in the total population. In general, persons in a given segment travel as much as the average person if their market size equals to their population size; they travel more if their market size exceeds their population size; and they travels less if their market size is smaller than their population size. If non-drivers make 20 percent of all transit trips but represent only 10 percent of the total population, for example, one can determine that non-drivers use transit twice as much as the average person in the total population.

The results on market size, population size, and modal share are presented for Florida and the U.S. as a whole. All of these are done for each of the eight socio-demographic and travel characteristics used to define transit markets. These characteristics include:

- Driver status

- Immigration status

- Medical conditions

- Household income

- Vehicle availability

- Race and ethnicity

- Frequency of transit use

- Trip purpose 


\subsection{Driver Status}

The driver status of a person refers to whether this person is a driver of POVs. The travel markets based on driver status include children under 15 years of age, drivers, and non-drivers. Children and non-drivers are considered part of the transportation-disadvantaged population, as these persons, even when living in households with vehicles available, rely on others for motorized transportation. In addition, many of the non-drivers are older adults who either have never learned to drive or have stopped driving, perhaps because of medical reasons. Older adults are persons who are ages 65 years or older.

\subsubsection{Market Size}

Table 3.1 presents the results on market size for travel segments by driver status for each mode and all modes combined and for Florida and the U.S. Note that the blank cells, as indicated with "-," for non-drivers simply mean that they did not drive on their travel day. For children age 14 years or younger, the blank cell for Florida is consistent with the fact that Florida does not allow them to drive; the near zero number for the U.S. is consistent with the fact some states do allow all or some persons beginning at age 14 to drive.

In general blank cells appear in this and other tables in this report for one of several possible reasons. Some appear because two population segments do not overlap. For example, older age segments would be blank for the Children market when person age is cross-tabulated with driver status. Some appear because they are behaviorally expected. For example, non-drivers do not drive as in this table. However, most blank cells appear because no data points are available.

Table 3.1. Market Size for Segments by Driver Status

\begin{tabular}{|c|c|c|c|c|c|}
\hline \multirow{2}{*}{$\begin{array}{l}\text { Florida } \\
\text { vs. U.S. }\end{array}$} & \multirow[b]{2}{*}{ Main Modes } & \multicolumn{3}{|c|}{ Segments by Driver Status } & \multirow[b]{2}{*}{ Total } \\
\hline & & Children & Driver & $\begin{array}{l}\text { Non- } \\
\text { Driver }\end{array}$ & \\
\hline \multirow{8}{*}{ Florida } & POV driver & -- & $100.0 \%$ & -- & $100.0 \%$ \\
\hline & POV passenger & $37.9 \%$ & $48.6 \%$ & $13.5 \%$ & $100.0 \%$ \\
\hline & Transit & $3.1 \%$ & $86.2 \%$ & $10.7 \%$ & $100.0 \%$ \\
\hline & Walk & $12.8 \%$ & $74.1 \%$ & $13.1 \%$ & $100.0 \%$ \\
\hline & Bike & $25.2 \%$ & $62.4 \%$ & $12.4 \%$ & $100.0 \%$ \\
\hline & Other & $44.7 \%$ & $28.6 \%$ & $26.7 \%$ & $100.0 \%$ \\
\hline & All modes & $10.1 \%$ & $85.1 \%$ & $4.8 \%$ & $100.0 \%$ \\
\hline & Population & $13.0 \%$ & $76.8 \%$ & $10.1 \%$ & $100.0 \%$ \\
\hline \multirow{8}{*}{ U.S. } & POV driver & $0.0 \%$ & $100.0 \%$ & -- & $100.0 \%$ \\
\hline & POV passenger & $41.4 \%$ & $43.5 \%$ & $15.0 \%$ & $100.0 \%$ \\
\hline & Transit & $6.4 \%$ & $81.2 \%$ & $12.4 \%$ & $100.0 \%$ \\
\hline & Walk & $15.1 \%$ & $69.0 \%$ & $15.9 \%$ & $100.0 \%$ \\
\hline & Bike & $36.0 \%$ & $52.3 \%$ & $11.7 \%$ & $100.0 \%$ \\
\hline & Other & $50.8 \%$ & $26.6 \%$ & $22.6 \%$ & $100.0 \%$ \\
\hline & All modes & $11.6 \%$ & $82.7 \%$ & $5.7 \%$ & $100.0 \%$ \\
\hline & Population & $14.2 \%$ & $75.0 \%$ & $10.8 \%$ & $100.0 \%$ \\
\hline
\end{tabular}




\section{U.S.}

Non-drivers make up 10.8 percent of the population, but they make only 5.7 percent of travel by all modes, implying that they travel almost one half as much as the average person. Children also travel less than the average person, but to a far lesser degree than non-drivers. Drivers travel more than the average person, in part, likely because they often transport a child or a non-driver.

One may think that non-drivers are heavy users of transit, but they are not. Non-drivers use transit only slightly more than the average person (12.4\% vs. a population share of $10.8 \%)$. Instead of transit, they ride as a POV passenger (15.0\%), walk (15.9\%), and use modes in the Other modal group $(22.6 \%)$ significantly more than the average person. Non-drivers bike barely more than the average person (11.7\% vs. its population share of $10.8 \%)$.

Children use transit significantly less than the average person $(6.4 \%$ of all transit trips vs. their population share of $14.2 \%)$. Instead, they ride as a POV passenger (41.4\%), bike (36.0\%), and use the modes in the Other group (e.g., school bus) far more than the average person.

Neither non-drivers nor children are large markets for public transit. Combined, they represent onequarter of the total population, but capture only 18.8 percent of all transit trips.

\section{Florida}

Florida is similar to the U.S. with regard to travel segments by driver status, but with a few notable differences:

- Non-drivers travel significantly less than the average person in Florida but more than the U.S. as a whole. They represent 10.1 percent of the population, but make only 4.8 percent of all travel, traveling less than one-half that of the average person.

- Transit plays a less significant role in moving children and non-drivers than the U.S. as a whole. Children represent 13.0 percent of the population but make only 3.1 percent of all transit trips, less than one-quarter of their population share. Non-drivers make just 10.7 percent of all transit trips, barely more than their population share of 10.1 percent.

- Non-drivers and children are smaller markets for public transit in Florida than in the U.S.

\subsubsection{Modal Share}

Table 3.2 presents the results on modal share for transit and other modes for each of the travel segments based on driver status. The last column on the right side of the table shows the modal shares for the total population. This last column also is present in similar tables for the other characteristics used to define travel segments. These aggregate modal shares may differ slightly across the characteristics. These slight differences result from the fact that total modal shares for 
Florida and the U.S. are calculated with the person-trips with no missing information on these characteristics, but the pattern of missing data varies across these characteristics. In addition, the aggregate modal shares in the last column for modes other than POV driver and POV passenger may differ from those calculated directly from information on the main mode of person trips. When modal shares are calculated with information on the main mode only, only person-trips with missing information on the main mode are excluded. The modes specified in these tables, however, are based on information not only on the main mode but also on whether a POV occupant was the driver. As a result, the modal shares in these tables also exclude person-trips with missing information on whether a POV occupant was the driver.

Table 3.2. Modal Share for Segments by Driver Status

\begin{tabular}{|l|l|r|r|r|r|}
\hline \multirow{2}{*}{$\begin{array}{l}\text { Florida } \\
\text { vs. U.S. }\end{array}$} & Main Modes & \multicolumn{3}{|c|}{ Driver Status } & \multirow{2}{*}{ Total } \\
\cline { 2 - 5 } & Children & Driver & $\begin{array}{c}\text { Non- } \\
\text { Driver }\end{array}$ & \\
\hline \multirow{4}{*}{ Florida } & POV driver & -- & $77.7 \%$ & -- & $66.1 \%$ \\
& POV passenger & $72.6 \%$ & $11.0 \%$ & $53.8 \%$ & $19.3 \%$ \\
& Transit & $.3 \%$ & $1.1 \%$ & $2.4 \%$ & $1.1 \%$ \\
& Walk & $12.2 \%$ & $8.4 \%$ & $26.1 \%$ & $9.6 \%$ \\
& Bike & $3.3 \%$ & $1.0 \%$ & $3.4 \%$ & $1.3 \%$ \\
& Other & $11.5 \%$ & $.9 \%$ & $14.4 \%$ & $2.6 \%$ \\
\cline { 2 - 5 } & All modes & $100.0 \%$ & $100.0 \%$ & $100.0 \%$ & $100.0 \%$ \\
\hline \hline \multirow{5}{*}{ U.S. } & POV driver & $0.0 \%$ & $77.1 \%$ & -- & $63.7 \%$ \\
& POV passenger & $68.1 \%$ & $10.1 \%$ & $50.6 \%$ & $19.1 \%$ \\
& Transit & $1.1 \%$ & $2.0 \%$ & $4.5 \%$ & $2.1 \%$ \\
& Walk & $14.3 \%$ & $9.2 \%$ & $30.7 \%$ & $11.0 \%$ \\
& Bike & $3.5 \%$ & $0.7 \%$ & $2.3 \%$ & $1.1 \%$ \\
& Other & $13.0 \%$ & $1.0 \%$ & $11.8 \%$ & $3.0 \%$ \\
\cline { 2 - 5 } & All modes & $100.0 \%$ & $100.0 \%$ & $100.0 \%$ & $100.0 \%$ \\
\hline
\end{tabular}

\section{U.S.}

Non-drivers rely primarily on being a POV passenger or walking for their daily travel. They make one half of their trips as passengers of a POV (50.6\%) and 30.7 percent by walking. Relative to these two modes, transit and biking play a small role, with transit capturing 4.5 percent and biking capturing 2.3 percent of their travel.

Children make more than two-thirds of their travel as a POV passenger (68.1\%). While relying on biking slightly more than non-drivers $(3.5 \%)$, they rely on transit or walking far less than non-drivers (1.1\% and $14.3 \%$, respectively).

In contrast, drivers drive themselves more than three-quarters of the time $(77.1 \%)$ and walk or ride as a POV passenger one-tenth of the time $(9.2 \%$ and $10.1 \%$, respectively). They use transit less than one-half as often as non-drivers, but about twice as often as children. 


\section{Florida}

Florida is similar to the U.S. in modal share for each travel segment by driver status. One notable difference is that all three segments rely less on transit and walking. Non-drivers in Florida, for example, make 2.4 percent of their travel by transit and 26.1 percent by walking. For non-drivers in the U.S., these percentages are 4.5 percent and 30.7 percent, respectively. Both drivers and nondrivers in Florida are more likely to bike than their counterparts in the U.S.

\subsection{Immigration Status}

Immigrants have traditionally been considered an important market for both current and future transit services. Many immigrants, particularly the newly-arrived, are disadvantaged in terms of transportation and economic conditions.

\subsubsection{Market Size}

Table 3.3 shows results for market size for segments defined on the basis of immigration status for each mode and for Florida and the U.S.

Table 3.3. Market Size for Segments by Immigration Status

\begin{tabular}{|l|l|r|r|r|r|}
\hline \multirow{2}{*}{$\begin{array}{l}\text { Florida } \\
\text { vs. U.S. }\end{array}$} & Main Modes & $\begin{array}{c}\text { New } \\
\text { Immigrant }\end{array}$ & $\begin{array}{c}\text { Older } \\
\text { Immigrant }\end{array}$ & $\begin{array}{c}\text { Non- } \\
\text { Immigrant }\end{array}$ & \multirow{2}{*}{ Total } \\
\hline \multirow{5}{*}{ Florida } & POV driver & $4.2 \%$ & $15.4 \%$ & $80.3 \%$ & $100.0 \%$ \\
& POV passenger & $3.3 \%$ & $9.5 \%$ & $87.3 \%$ & $100.0 \%$ \\
& Transit & $23.2 \%$ & $20.5 \%$ & $56.3 \%$ & $100.0 \%$ \\
& Walk & $4.3 \%$ & $12.8 \%$ & $82.9 \%$ & $100.0 \%$ \\
& Bike & $6.8 \%$ & $6.8 \%$ & $86.3 \%$ & $100.0 \%$ \\
& Other & $2.5 \%$ & $5.9 \%$ & $91.6 \%$ & $100.0 \%$ \\
\cline { 2 - 5 } & All modes & $4.2 \%$ & $13.7 \%$ & $82.0 \%$ & $100.0 \%$ \\
\cline { 2 - 5 } & Population & $4.6 \%$ & $14.0 \%$ & $81.3 \%$ & $100.0 \%$ \\
\hline \hline \multirow{5}{*}{ U.S. } & POV driver & $2.3 \%$ & $9.2 \%$ & $88.5 \%$ & $100.0 \%$ \\
& POV passenger & $2.2 \%$ & $5.7 \%$ & $92.1 \%$ & $100.0 \%$ \\
& Transit & $8.2 \%$ & $22.2 \%$ & $69.6 \%$ & $100.0 \%$ \\
& Walk & $3.9 \%$ & $11.2 \%$ & $84.9 \%$ & $100.0 \%$ \\
& Bike & $2.2 \%$ & $7.5 \%$ & $90.2 \%$ & $100.0 \%$ \\
& Other & $1.9 \%$ & $3.4 \%$ & $94.7 \%$ & $100.0 \%$ \\
\cline { 2 - 5 } & All modes & $2.6 \%$ & $8.8 \%$ & $88.6 \%$ & $100.0 \%$ \\
\cline { 2 - 5 } & Population & $2.8 \%$ & $8.8 \%$ & $88.5 \%$ & $100.0 \%$ \\
\hline
\end{tabular}

U.S.

Immigration status does not appear to make much difference in the amount of travel people make; immigrants do not travel any less than the average person. Immigrants represent 11.6 percent of the U.S. population, with 2.8 percent new immigrants and 8.8 percent older immigrants. New immigrants travel a slightly smaller share by all modes $(2.6 \%)$ than their share of the population $(2.8 \%)$; they travel less than the average person, but only slightly so. Older immigrants travel 
exactly the same share by all modes $(8.8 \%)$ as their share of the population; they travel just as much as the average person.

Immigrants represent a significant portion of the overall transit market. New immigrants constitute 8.2 percent and older immigrants 22.2 percent of all transit travel, a total of 30.4 percent of the overall transit market. In comparison, non-drivers represent only 12.4 percent of the overall transit market; the population share of immigrants is only slightly higher than that of non-drivers $(11.6 \%$ vs. $10.8 \%)$.

Immigrants use transit far more than the average person, capturing a total of 30.4 percent of the overall transit market while representing only 11.6 percent of the overall population. They also walk more than the average person, although to a lesser degree than using transit. New immigrants travel less than the average person in terms of driving themselves, riding as a POV passenger, or biking. Older immigrants also travel less than the average person by riding as a POV passenger or by biking, but they drive more than the average person.

\section{Florida}

Immigrants constitute a larger share of the Florida population than the U.S. as a whole. New immigrants make up 4.6 percent of the population in Florida vs. 2.8 percent for the U.S. Older immigrants make up 14.0 percent of the population in Florida vs. 8.8 percent for the U.S. The most notable difference from the U.S. is that new immigrants are a far more important market for transit in Florida than in the U.S. as a whole. While new immigrants make only 8.2 percent of all transit travel in the U.S., they make almost one-quarter of all transit travel in Florida (23.2\%). In addition, older immigrants make 20.5 percent of all transit travel in Florida, for an overall share of 43.5 percent of the total transit market in Florida. In comparison, non-drivers make up only 10.7 percent of the transit market in Florida.

\subsubsection{Modal Share}

Table 3.4 presents results on modal share for transit and other modes for each segment defined by immigration status.

U.S.

Older immigrants drive just as likely as non-immigrants. New-immigrants are more likely to use transit or walk than both older immigrants and non-immigrants but less likely to ride as a POV passenger than non-immigrants. Relative to older immigrants, new immigrants drive less by 10 percent, but they are more likely to ride as a POV passenger, walk, or use transit. While transit plays a far more important role for immigrants than for non-immigrants, its role is still minor relative to driving, riding in a POV, or walking. The likelihood of travel by bike is low $(\sim 1.0 \%$ for all travel segments, including new immigrants). This is somewhat surprising, given that many new immigrants may have come from a background where biking is likely to be a widely-used mode. 
Table 3.4. Modal Share for Segments by Immigration Status

\begin{tabular}{|l|l|r|r|r|r|}
\hline \multirow{2}{*}{$\begin{array}{l}\text { Florida } \\
\text { vs. U.S. }\end{array}$} & \multirow{2}{*}{ Main Modes } & $\begin{array}{c}\text { New } \\
\text { Immigrant }\end{array}$ & $\begin{array}{c}\text { Older } \\
\text { Immigrant }\end{array}$ & $\begin{array}{c}\text { Non- } \\
\text { Immigrant }\end{array}$ & \multirow{2}{*}{ Total } \\
\hline \multirow{4}{*}{ Imorida } & POV driver & $66.0 \%$ & $74.3 \%$ & $64.7 \%$ & $66.1 \%$ \\
& POV passenger & $14.8 \%$ & $13.4 \%$ & $20.6 \%$ & $19.3 \%$ \\
& Transit & $5.8 \%$ & $1.6 \%$ & $0.7 \%$ & $1.1 \%$ \\
& Walk & $9.7 \%$ & $8.9 \%$ & $9.7 \%$ & $9.6 \%$ \\
& Bike & $2.1 \%$ & $0.7 \%$ & $1.4 \%$ & $1.3 \%$ \\
& Other & $1.6 \%$ & $1.1 \%$ & $2.9 \%$ & $2.6 \%$ \\
\cline { 2 - 6 } & All modes & $100.0 \%$ & $100.0 \%$ & $100.0 \%$ & $100.0 \%$ \\
\hline \hline \multirow{3}{*}{ U.S. } & POV driver & $56.6 \%$ & $66.5 \%$ & $63.6 \%$ & $63.7 \%$ \\
& POV passenger & $16.7 \%$ & $12.3 \%$ & $19.9 \%$ & $19.1 \%$ \\
& Transit & $6.5 \%$ & $5.1 \%$ & $1.6 \%$ & $2.0 \%$ \\
& Walk & $17.0 \%$ & $13.9 \%$ & $10.5 \%$ & $11.0 \%$ \\
& Bike & $1.0 \%$ & $1.0 \%$ & $1.1 \%$ & $1.1 \%$ \\
& Other & $2.2 \%$ & $1.1 \%$ & $3.2 \%$ & $3.0 \%$ \\
\cline { 2 - 5 } & All modes & $100.0 \%$ & $100.0 \%$ & $100.0 \%$ & $100.0 \%$ \\
\hline
\end{tabular}

\section{Florida}

Non-immigrants in Florida and the U.S. are similar in their modal choices. However, both new and older immigrants in Florida are far more likely to drive than those in the U.S. New immigrants, for example, drive 66.0 percent of the time in Florida vs. 56.6 percent in the U.S., but they are less likely to walk or use transit than their U.S. counterparts. Most notable is that older immigrants in Florida make only 1.6 percent of their travel by transit vs. 5.1 percent in the U.S.

\subsection{Medical Conditions}

Persons with medical conditions that make it difficult to travel outside of the home are considered transportation disadvantaged. In addition, many with medical conditions are likely to be older adults, many of whom may be economically disadvantaged. This study considers two travel segments based on medical conditions: those having a medical condition and all others.

\subsubsection{Market Size}

Table 3.5 shows results on market size for the two segments based on medical conditions for each mode and for Florida and the U.S.

\section{U.S.}

Persons with medical conditions travel less than the average person. About one-tenth of the U.S. population has at least one medical condition that would make it difficult to travel outside of the home $(10.3 \%)$. Persons with these medical conditions make only 6.4 percent of all travel by all modes. This significantly reduced mobility is similar to that for non-drivers, as discussed earlier. This significant reduction in mobility is largely reflected in their driving, walking, and biking relative to the average person. Persons with medical conditions make up only 4.9 percent of all driving, 7.8 
percent of all walking, and 4.2 percent of all biking travel, but they make up 10.3 percent of the overall population.

Persons with medical conditions do not represent a significant market for transit. While they represent 10.3 percent of the total population, they make up just 10.9 percent of all transit travel, implying they use transit similar to the average person.

Table 3.5. Market Size for Segments by Medical Conditions

\begin{tabular}{|l|l|r|r|r|}
\hline \multirow{3}{*}{$\begin{array}{l}\text { Florida } \\
\text { vs. U.S. }\end{array}$} & Main Modes & \multicolumn{2}{|c|}{$\begin{array}{c}\text { Existence of Medical } \\
\text { Conditions }\end{array}$} & \multirow{2}{*}{ Total } \\
\cline { 2 - 4 } & & $\begin{array}{c}\text { Having } \\
\text { Medical } \\
\text { Conditions }\end{array}$ & $\begin{array}{c}\text { Nodical } \\
\text { Conditions }\end{array}$ & \\
\hline \multirow{5}{*}{ Florida } & POV driver & $4.7 \%$ & $95.3 \%$ & $100.0 \%$ \\
& POV passenger & $15.1 \%$ & $84.9 \%$ & $100.0 \%$ \\
& Transit & $13.7 \%$ & $86.3 \%$ & $100.0 \%$ \\
& Walk & $7.4 \%$ & $92.6 \%$ & $100.0 \%$ \\
& Bike & $6.2 \%$ & $93.8 \%$ & $100.0 \%$ \\
& Other & $23.6 \%$ & $76.4 \%$ & $100.0 \%$ \\
\cline { 2 - 5 } & All modes & $6.7 \%$ & $93.3 \%$ & $100.0 \%$ \\
\cline { 2 - 5 } & Population & $11.1 \%$ & $88.9 \%$ & $100.0 \%$ \\
\hline \hline \multirow{5}{*}{ U.S. } & POV driver & $4.9 \%$ & $95.1 \%$ & $100.0 \%$ \\
& POV passenger & $12.4 \%$ & $87.6 \%$ & $100.0 \%$ \\
& Transit & $10.9 \%$ & $89.1 \%$ & $100.0 \%$ \\
& Walk & $7.8 \%$ & $92.2 \%$ & $100.0 \%$ \\
& Bike & $4.2 \%$ & $95.8 \%$ & $100.0 \%$ \\
& Other & $19.6 \%$ & $80.4 \%$ & $100.0 \%$ \\
\cline { 2 - 5 } & All modes & $6.4 \%$ & $93.6 \%$ & $100.0 \%$ \\
\cline { 2 - 5 } & Population & $10.3 \%$ & $89.7 \%$ & $100.0 \%$ \\
\hline
\end{tabular}

\section{Florida}

Florida has a slightly larger share of population with a medical condition than the U.S. as a whole $(11.1 \%$ vs. $10.3 \%)$. In addition, persons with medical conditions in Florida reduce travel just as much as those in the U.S. However, persons with medical conditions represent a slightly larger market for transit in Florida than in the U.S. as a whole (13.7\% vs. $10.9 \%)$.

\subsubsection{Modal Share}

Table 3.6 presents results on modal share for each travel segment based on medical conditions for Florida and the U.S.

U.S.

Persons with medical conditions drive 55.3 percent of the time for local travel, which is almost 20 percent lower than those without medical conditions (74.2\%). Instead, they rely significantly more on riding as a POV passenger (23.2\%) and on walking $(12.8 \%)$. While they also use transit and 
other modes more often than persons without medical conditions, the overall role of these modes is still extremely minor compared to walking and POV riding.

Table 3.6. Modal Shares for Segments by Medical Conditions

\begin{tabular}{|l|l|r|r|r|}
\hline \multirow{2}{*}{$\begin{array}{l}\text { Florida } \\
\text { vs. U.S. }\end{array}$} & Main Modes & \multicolumn{2}{|c|}{$\begin{array}{c}\text { Existence of Medical } \\
\text { Conditions }\end{array}$} & \multirow{2}{*}{ Total } \\
\cline { 3 - 5 } & & $\begin{array}{c}\text { Having } \\
\text { Medical } \\
\text { Conditions }\end{array}$ & $\begin{array}{c}\text { No } \\
\text { Medical } \\
\text { Conditions }\end{array}$ & \\
\hline \multirow{5}{*}{ Florida } & POV driver & $52.4 \%$ & $75.8 \%$ & $74.3 \%$ \\
& POV passenger & $29.0 \%$ & $11.6 \%$ & $12.8 \%$ \\
& Transit & $2.3 \%$ & $1.1 \%$ & $1.1 \%$ \\
& Walk & $10.3 \%$ & $9.2 \%$ & $9.3 \%$ \\
& Bike & $1.0 \%$ & $1.1 \%$ & $1.1 \%$ \\
& Other & $5.0 \%$ & $1.2 \%$ & $1.4 \%$ \\
\cline { 2 - 5 } & All modes & $100.0 \%$ & $100.0 \%$ & $100.0 \%$ \\
\hline \hline \multirow{5}{*}{ U.S. } & POV driver & $55.3 \%$ & $74.2 \%$ & $73.0 \%$ \\
& POV passenger & $23.2 \%$ & $11.3 \%$ & $12.0 \%$ \\
& Transit & $3.7 \%$ & $2.1 \%$ & $2.2 \%$ \\
& Walk & $12.8 \%$ & $10.3 \%$ & $10.5 \%$ \\
& Bike & $0.5 \%$ & $0.8 \%$ & $.8 \%$ \\
& Other & $4.5 \%$ & $1.3 \%$ & $1.5 \%$ \\
\cline { 2 - 5 } & All modes & $100.0 \%$ & $100.0 \%$ & $100.0 \%$ \\
\hline
\end{tabular}

\section{Florida}

The overall pattern of modal shares across the modes and between the two travel segments is highly similar to the U.S. However, the differences between the two segments are larger, especially for POV driving and riding. Persons with medical conditions drive only 52.4 percent of the time vs. 75.8 percent for persons without medical conditions, a difference of -23.4 percent. For the U.S., the difference for POV driving is -19.0 percent. At the same time, persons with medical conditions ride as a POV passengers 29.0 percent of the time vs. 11.6 percent for persons without medical conditions, a difference of 17.4 percentage points. For the U.S., the difference for POV riding is 11.9 percent.

\subsection{Household Race and Ethnicity}

Many persons of a minority race or ethnicity are economically disadvantaged, and, as a result, they become transportation disadvantaged. Understanding their travel is important from the perspective of public policy considerations. This study defines four travel segments that are based on race and ethnicity:

- Hispanic

- Non-Hispanic White

- Non-Hispanic Black

- Non-Hispanic Other 
The focus here is on Hispanics and Non-Hispanic Blacks.

\subsubsection{Market Size}

Table 3.7 shows results on market size for segments based on race and ethnicity for each mode and for Florida and the U.S.

Table 3.7. Market Size for Segments by Race and Ethnicity

\begin{tabular}{|c|c|c|c|c|c|c|}
\hline \multirow[b]{2}{*}{$\begin{array}{l}\text { Florida } \\
\text { vs. U.S. }\end{array}$} & \multirow[b]{2}{*}{ Main Modes } & \multicolumn{4}{|c|}{ Household Race and Ethnicity } & \multirow[b]{2}{*}{ Total } \\
\hline & & Hispanic & $\begin{array}{c}\text { Non- } \\
\text { Hispanic } \\
\text { White }\end{array}$ & $\begin{array}{c}\text { Non- } \\
\text { Hispanic } \\
\text { Black }\end{array}$ & $\begin{array}{c}\text { Non- } \\
\text { Hispanic } \\
\text { Other }\end{array}$ & \\
\hline \multirow{8}{*}{ Florida } & POV driver & $18.6 \%$ & $64.1 \%$ & $12.6 \%$ & $4.7 \%$ & $100.0 \%$ \\
\hline & POV passenger & $21.7 \%$ & $59.4 \%$ & $12.3 \%$ & $6.5 \%$ & $100.0 \%$ \\
\hline & Transit & $38.2 \%$ & $21.5 \%$ & $36.8 \%$ & $3.5 \%$ & $100.0 \%$ \\
\hline & Walk & $17.9 \%$ & $61.8 \%$ & $14.5 \%$ & $5.8 \%$ & $100.0 \%$ \\
\hline & Bike & $17.1 \%$ & $69.9 \%$ & $7.0 \%$ & $6.0 \%$ & $100.0 \%$ \\
\hline & Other & $19.7 \%$ & $46.3 \%$ & $26.2 \%$ & $7.8 \%$ & $100.0 \%$ \\
\hline & All modes & $19.4 \%$ & $62.1 \%$ & $13.3 \%$ & $5.2 \%$ & $100.0 \%$ \\
\hline & Population & $20.8 \%$ & $59.5 \%$ & $14.8 \%$ & $5.0 \%$ & $100.0 \%$ \\
\hline \multirow{8}{*}{ U.S. } & POV driver & $11.9 \%$ & $73.3 \%$ & $10.2 \%$ & $4.6 \%$ & $100.0 \%$ \\
\hline & POV passenger & $16.7 \%$ & $68.1 \%$ & $9.5 \%$ & $5.7 \%$ & $100.0 \%$ \\
\hline & Transit & $29.0 \%$ & $31.3 \%$ & $32.2 \%$ & $7.5 \%$ & $100.0 \%$ \\
\hline & Walk & $18.7 \%$ & $62.6 \%$ & $13.0 \%$ & $5.7 \%$ & $100.0 \%$ \\
\hline & Bike & $13.2 \%$ & $71.5 \%$ & $11.4 \%$ & $3.9 \%$ & $100.0 \%$ \\
\hline & Other & $15.0 \%$ & $62.4 \%$ & $17.8 \%$ & $4.8 \%$ & $100.0 \%$ \\
\hline & All modes & $14.0 \%$ & $69.9 \%$ & $11.0 \%$ & $5.0 \%$ & $100.0 \%$ \\
\hline & Population & $15.1 \%$ & $67.5 \%$ & $12.1 \%$ & $5.3 \%$ & $100.0 \%$ \\
\hline
\end{tabular}

\section{U.S.}

Hispanics and Non-Hispanic Blacks travel slightly less than the average person in the U.S. Hispanics are 15.1 percent of the total population but make 14.0 percent of the total travel. Similarly, Non-Hispanic Blacks are 12.1 percent of the total population, but make 11.0 percent of the total travel. Both segments use transit and walk more than the average person. This increased mobility by these two modes is not enough to compensate for their reduced mobility by some other modes. These modes include POV driving and biking for both travel segments. For Non-Hispanic Blacks, these modes also include riding as a POV passenger.

Non-Hispanic Blacks use transit several times more than the average person, and more than Hispanics. They make almost one-third of all travel by transit $(32.2 \%)$ but make up only slightly more than one-eighth of the total population (12.1\%). Hispanics make a smaller share of all travel by transit (29.0\%) and represent a larger share of the total population (15.1\%). 
Both Hispanics and Non-Hispanic Blacks are large markets for transit. Combined, they represent 61.2 percent of all travel by transit, with 29.0 percent for Hispanics and 32.2 percent for NonHispanic Blacks.

\section{Florida}

Hispanics and Non-Hispanic Blacks represent larger shares of the total population in Florida than in the U.S., with a total combined share of 35.6 percent for Florida vs. 27.2 percent for the U.S.

Hispanics and Non-Hispanic Blacks dominate the transit market in Florida. Hispanics make 38.2 percent of their travel by transit and Non-Hispanic Blacks 36.8 percent. Together, they represent three-fourths of the transit market in Florida (75.0\%).

\subsubsection{Modal Share}

Table 3.8 shows results on modal share for segments by race and ethnicity for Florida and the U.S.

Table 3.8. Modal Share for Segments by Race and Ethnicity

\begin{tabular}{|l|l|r|r|r|r|r|}
\hline \multirow{2}{*}{$\begin{array}{l}\text { Florida } \\
\text { vs. U.S. }\end{array}$} & Main Modes & Hispanic & $\begin{array}{c}\text { Non- } \\
\text { Hispanic } \\
\text { White }\end{array}$ & $\begin{array}{c}\text { Non- } \\
\text { Hispanic } \\
\text { Black }\end{array}$ & $\begin{array}{c}\text { Non- } \\
\text { Hispanic } \\
\text { Other }\end{array}$ & \multirow{2}{*}{ Total } \\
\hline \multirow{5}{*}{ Florida } & POV driver & $63.5 \%$ & $68.2 \%$ & $62.8 \%$ & $59.0 \%$ & $66.1 \%$ \\
& POV passenger & $21.7 \%$ & $18.5 \%$ & $17.9 \%$ & $24.1 \%$ & $19.3 \%$ \\
& Transit & $2.1 \%$ & $0.4 \%$ & $3.0 \%$ & $0.7 \%$ & $1.1 \%$ \\
& Walk & $8.9 \%$ & $9.5 \%$ & $10.5 \%$ & $10.7 \%$ & $9.6 \%$ \\
& Bike & $1.2 \%$ & $1.5 \%$ & $0.7 \%$ & $1.5 \%$ & $1.3 \%$ \\
& Other & $2.7 \%$ & $1.9 \%$ & $5.1 \%$ & $3.9 \%$ & $2.6 \%$ \\
\cline { 2 - 6 } & All modes & $100.0 \%$ & $100.0 \%$ & $100.0 \%$ & $100.0 \%$ & $100.0 \%$ \\
\hline \hline \multirow{5}{*}{ U.S. } & POV driver & $54.1 \%$ & $66.8 \%$ & $58.7 \%$ & $58.8 \%$ & $63.7 \%$ \\
& POV passenger & $22.8 \%$ & $18.7 \%$ & $16.5 \%$ & $21.8 \%$ & $19.2 \%$ \\
& Transit & $4.2 \%$ & $0.9 \%$ & $5.9 \%$ & $3.0 \%$ & $2.0 \%$ \\
& Walk & $14.6 \%$ & $9.8 \%$ & $12.9 \%$ & $12.6 \%$ & $11.0 \%$ \\
& Bike & $1.1 \%$ & $1.1 \%$ & $1.2 \%$ & $0.9 \%$ & $1.1 \%$ \\
& Other & $3.2 \%$ & $2.7 \%$ & $4.8 \%$ & $2.9 \%$ & $3.0 \%$ \\
\cline { 2 - 6 } & All modes & $100.0 \%$ & $100.0 \%$ & $100.0 \%$ & $100.0 \%$ & $100.0 \%$ \\
\hline
\end{tabular}

\section{U.S.}

Both Hispanics and Non-Hispanic Blacks are highly dependent on POV driving and riding.

Hispanics drive 54.1 percent of the time and ride as a POV passenger 22.8 percent of the time, with a combined total of 76.9 percent. Non-Hispanic Blacks drive 58.7 percent of the time and ride as a POV passenger 16.5 percent, a combined total of 75.2 percent. This high dependence on POVs by Hispanics and Non-Hispanic Blacks is still about 10 percent lower than the dependence of NonHispanic Whites (85.5\%). Hispanics and Non-Hispanic Blacks overcome this lower dependence on POVs by walking more and riding transit more. 
Transit does not play a significant role for any of these travel segments. Relative to the overall travel market, however, Hispanics are about twice as likely (4.2\% vs. $2.0 \%)$ and Non-Hispanic Blacks are about three times as likely $(5.9 \%$ vs. $2.0 \%)$ to use transit.

There are some notable differences between Hispanics and Non-Hispanic Blacks. Hispanics are less likely to drive but more likely to ride as a POV passenger. On the other hand, Non-Hispanic Blacks are more likely to use transit but less likely to walk than Hispanics.

\section{Florida}

Hispanics in Florida are far more likely to drive than Hispanics in the U.S. as a whole (63.5\% vs. $54.1 \%$ ). On the other hand, Hispanics in Florida are less likely to ride as a POV passenger, use transit, or walk than Hispanics in the U.S. as a whole. Non-Hispanic Blacks in Florida also are more likely to drive than Hispanics in the U.S. but to a lesser degree than Hispanics (62.8\% vs. $58.7 \%$ ). Except for Non-Hispanic Others, the other three travel segments in Florida are similar in that they all are about one-half as likely to use transit as those in the U.S. as a whole. Hispanics, for example, use transit 4.2 percent of the time in the U.S. as a whole but use transit only 2.1 percent of the time in Florida.

\subsection{Household Income}

Annual household income is an important indicator of a household's economic well-being. Households with extremely low income are considered to be economically disadvantaged for transportation purposes. In addition, many of the households with low income are headed by older adults, who rely largely on fixed income sources. The current study considers four travel segments based on household income:

- Low income - under $\$ 15,000$

- Middle low-income - $\$ 15,000-\$ 49,999$

- Middle high-income $-\$ 50,000-\$ 99,999$

- High income $-\$ 100,000+$

\subsubsection{Market Size}

Table 3.9 presents results on market size for segments based on household income for each mode and for Florida and the U.S.

U.S.

Persons from low-income households travel significantly less than the average person. They constitute 11.7 percent of the total population, but make only 8.6 percent of all travel by all modes. This reduced mobility is largely the result of driving and riding POVs far less than the average person. In fact, they make up 6.7 percent of all driving and 7.8 percent of all riding as a POV 
passenger, well under their share of the total population. They compensate by walking more and using transit significantly more than the average person.

Middle low-income persons also travel less than the average person but to a lesser degree than low-income persons. They constitute 35.4 percent of the total population and make 33.5 percent of all travel by all modes and travel less than the average person by all modes except transit.

The low-income and middle low-income travel segments are large markets for transit. The lowincome segment represents 28.9 percent of the overall transit market; the middle low-income segment represents 39.9 percent. Together, these two travel segments capture more than twothirds of the overall transit market $(68.8 \%)$. This is more than the portion of the transit market captured by Hispanics and Non-Hispanic Blacks (61.2\%).

Table 3.9. Market Size for Segments by Household Income

\begin{tabular}{|c|c|c|c|c|c|c|}
\hline \multirow[b]{2}{*}{$\begin{array}{l}\text { Florida } \\
\text { vs. U.S. }\end{array}$} & \multirow[b]{2}{*}{ Main Modes } & \multicolumn{4}{|c|}{ Annual Household Income } & \multirow[b]{2}{*}{ Total } \\
\hline & & $\begin{array}{c}\text { Under } \\
\$ 15,000 \\
\text { (low- } \\
\text { income) }\end{array}$ & $\begin{array}{l}\$ 15,000- \\
\$ 49,999 \\
\text { (middle } \\
\text { low- } \\
\text { income) }\end{array}$ & $\begin{array}{c}\$ 50,000- \\
\$ 99,999 \\
\text { (middle } \\
\text { high- } \\
\text { income) }\end{array}$ & $\begin{array}{c}\$ 100,000+ \\
\text { (high- } \\
\text { income) }\end{array}$ & \\
\hline \multirow{8}{*}{ Florida } & POV driver & $7.4 \%$ & $35.5 \%$ & $36.3 \%$ & $20.9 \%$ & $100.0 \%$ \\
\hline & POV passenger & $7.1 \%$ & $34.3 \%$ & $37.3 \%$ & $21.3 \%$ & $100.0 \%$ \\
\hline & Transit & $41.9 \%$ & $45.5 \%$ & $11.1 \%$ & $1.6 \%$ & $100.0 \%$ \\
\hline & Walk & $14.5 \%$ & $34.6 \%$ & $32.0 \%$ & $19.0 \%$ & $100.0 \%$ \\
\hline & Bike & $14.6 \%$ & $37.3 \%$ & $23.8 \%$ & $24.3 \%$ & $100.0 \%$ \\
\hline & Other & $16.2 \%$ & $36.5 \%$ & $29.4 \%$ & $17.9 \%$ & $100.0 \%$ \\
\hline & All modes & $8.7 \%$ & $35.3 \%$ & $35.5 \%$ & $20.5 \%$ & $100.0 \%$ \\
\hline & Population & $11.6 \%$ & $37.7 \%$ & $32.9 \%$ & $17.9 \%$ & $100.0 \%$ \\
\hline \multirow{8}{*}{ U.S. } & POV driver & $6.7 \%$ & $33.3 \%$ & $36.1 \%$ & $23.8 \%$ & $100.0 \%$ \\
\hline & POV passenger & $7.8 \%$ & $32.9 \%$ & $35.1 \%$ & $24.2 \%$ & $100.0 \%$ \\
\hline & Transit & $28.9 \%$ & $39.9 \%$ & $18.1 \%$ & $13.2 \%$ & $100.0 \%$ \\
\hline & Walk & $15.3 \%$ & $33.7 \%$ & $28.9 \%$ & $22.1 \%$ & $100.0 \%$ \\
\hline & Bike & $9.5 \%$ & $34.7 \%$ & $31.8 \%$ & $24.0 \%$ & $100.0 \%$ \\
\hline & Other & $15.3 \%$ & $33.5 \%$ & $29.8 \%$ & $21.4 \%$ & $100.0 \%$ \\
\hline & All modes & $8.6 \%$ & $33.5 \%$ & $34.5 \%$ & $23.4 \%$ & $100.0 \%$ \\
\hline & Population & $11.7 \%$ & $35.4 \%$ & $32.3 \%$ & $20.5 \%$ & $100.0 \%$ \\
\hline
\end{tabular}

\section{Florida}

Florida is similar to the U.S. as a whole in its size of travel markets across the segments based on household income for each mode, with one exception: the low- and middle low-income segments represent even larger markets for transit in Florida than in the U.S. as a whole. The low-income segment captures 41.9 percent of all travel by transit, and the middle low-income segment is 45.5 percent of the whole transit market. Together, they represent 87.4 percent of the entire transit market in Florida. This is significantly greater than the transit market captured by Hispanics and Non-Hispanic Blacks in Florida (75.0\%). 
The low-income segment in Florida is particularly different from that in the U.S. as a whole. Persons in the low-income segment in the U.S. already use transit significantly more than the average person, as indicated by their large share of 28.9 percent of the transit market vs. their share of 11.7 percent of the total population. In contrast, the degree to which persons in the lowincome segment in Florida use transit more than the average person is even greater than in the U.S. at 11.6 percent of the total population in Florida, but 41.9 percent of all transit trips.

\subsubsection{Modal Share}

Table 3.10 shows results of modal share for each income-based segment for Florida and the U.S.

Table 3.10. Modal Share for Segments by Household Income

\begin{tabular}{|c|c|c|c|c|c|c|}
\hline \multirow[b]{2}{*}{$\begin{array}{l}\text { Florida } \\
\text { vs. U.S. }\end{array}$} & \multirow[b]{2}{*}{ Main Modes } & \multicolumn{4}{|c|}{ Annual Household Income } & \multirow[b]{2}{*}{ Total } \\
\hline & & $\begin{array}{c}\text { Under } \\
\$ 15,000 \\
\text { (low- } \\
\text { income) }\end{array}$ & $\begin{array}{c}\$ 15,000- \\
\$ 49,999 \\
\text { (middle } \\
\text { low- } \\
\text { income) }\end{array}$ & $\begin{array}{c}\$ 50,000- \\
\$ 99,999 \\
\text { (middle } \\
\text { high- } \\
\text { income) }\end{array}$ & $\begin{array}{c}\$ 100,000+ \\
\text { (high- } \\
\text { income) }\end{array}$ & \\
\hline \multirow{7}{*}{ Florida } & POV Driver & $55.9 \%$ & $66.3 \%$ & $67.5 \%$ & $67.1 \%$ & $66.0 \%$ \\
\hline & POV Passenger & $15.7 \%$ & $18.7 \%$ & $20.4 \%$ & $20.1 \%$ & $19.3 \%$ \\
\hline & Transit & $5.2 \%$ & $1.4 \%$ & $0.3 \%$ & $0.1 \%$ & $1.1 \%$ \\
\hline & Walk & $16.1 \%$ & $9.4 \%$ & $8.7 \%$ & $8.9 \%$ & $9.7 \%$ \\
\hline & Bike & $2.2 \%$ & $1.4 \%$ & $0.9 \%$ & $1.6 \%$ & $1.3 \%$ \\
\hline & Other & $4.9 \%$ & $2.7 \%$ & $2.2 \%$ & $2.3 \%$ & $2.6 \%$ \\
\hline & All Modes & $100.0 \%$ & $100.0 \%$ & $100.0 \%$ & $100.0 \%$ & $100.0 \%$ \\
\hline \multirow{7}{*}{ U.S. } & POV Driver & $49.7 \%$ & $63.4 \%$ & $66.6 \%$ & $64.8 \%$ & $63.6 \%$ \\
\hline & POV Passenger & $17.4 \%$ & $18.9 \%$ & $19.5 \%$ & $19.8 \%$ & $19.2 \%$ \\
\hline & Transit & $6.9 \%$ & $2.5 \%$ & $1.1 \%$ & $1.2 \%$ & $2.1 \%$ \\
\hline & Walk & $19.5 \%$ & $11.1 \%$ & $9.2 \%$ & $10.4 \%$ & $11.0 \%$ \\
\hline & Bike & $1.2 \%$ & $1.2 \%$ & $1.0 \%$ & $1.2 \%$ & $1.1 \%$ \\
\hline & Other & $5.3 \%$ & $3.0 \%$ & $2.6 \%$ & $2.7 \%$ & $3.0 \%$ \\
\hline & All Modes & $100.0 \%$ & $100.0 \%$ & $100.0 \%$ & $100.0 \%$ & $100.0 \%$ \\
\hline
\end{tabular}

\section{U.S.}

The low-income segment is still highly dependent on travel by POV driving or riding, driving one-half the time $(49.7 \%)$ and riding as a POV passenger 17.4 percent of the time. Together, POV driving and riding serve more than two-thirds of all travel for the low-income segment $(67.1 \%)$. Besides relying on POVs, this segment walks for about one-fifth of their trips (19.5\%) and uses transit for 6.9 percent of their trips.

Transit still plays a small role in meeting the travel needs of the low-income segment. While this group relies on transit far more than other income segments, with a transit modal share of 6.9 percent vs. 2.5 percent for the middle low-income segment, 1.1 percent for the middle high-income segment, and 1.2 percent for the high-income segment, and is a huge market for transit, with 28.9 
percent of the entire transit market, it chooses to walk, drive, or ride as a POV passenger for the vast majority of their travel.

\section{Florida}

One notable difference between Florida and the U.S. as a whole is the role of transit. Transit serves 2.1 percent of all travel for the entire population in the U.S., but serves only 1.1 percent for the entire population in Florida. That is, residents of Florida are about one-half as likely to use transit as their national counterparts. However, in light of household income, transit serves 6.9 percent of the low-income segment's travel for the U.S. and 5.2 percent for Florida but well over one half of the modal share for the U.S. For the middle low-income segment, transit's modal share is 1.4 percent for Florida and also is more than one half of the 2.5 percent for the U.S. On the other hand, transit serves well less than 0.5 percent of their travel for the two high income segments in Florida.

\subsection{Vehicle Availability}

Having a vehicle available for use by members of a household is a significant convenience for sustaining daily life in the U.S. under the current patterns of land use and transportation networks. Lack of a household vehicle is considered transportation disadvantaged. This study defines three travel segments based on vehicle availability and goes one step beyond simply counting the number of vehicles available; it also considers how the number of vehicles available compares to the number of workers in the household:

- No vehicle available (zero-vehicle)

- Vehicles < workers (inadequate vehicles)

- Vehicles $\geq$ workers (adequate vehicles)

\subsubsection{Market Size}

Table 3.11 presents results on market size for segments based on vehicle availability as defined above for each mode and for Florida and the U.S.

\section{U.S.}

Similar to non-drivers and persons with medical conditions, persons in zero-vehicle households travel far less than the average person, with 6.1 percent of the total population but making only 3.7 percent of the total travel by all modes and little travel either by driving or by riding as a POV passenger. Instead, they use other modes significantly more than the average person, including transit, walking, biking, and modes in the Other modal group. Transit is especially significant. Persons in zero-vehicle households use transit about eight times as often as the average person. While they make up 6.1 percent of the total population, but they make 48.5 percent of all travel by transit. 
Persons in zero-vehicle households are almost one half of the total transit market $(48.5 \%)$ in the U.S. In addition, persons living in households with inadequate vehicles (fewer vehicles than workers) make up another 17.1 percent of the transit market. Combined, these two travel segments represent two-thirds of the overall transit market.

Table 3.11. Market Size for Segments by Vehicle Availability

\begin{tabular}{|c|c|c|c|c|c|}
\hline \multirow[b]{2}{*}{$\begin{array}{l}\text { Florida } \\
\text { vs. U.S. }\end{array}$} & \multirow[b]{2}{*}{ Main Modes } & \multicolumn{3}{|c|}{ Vehicles Relative to Workers } & \multirow[b]{2}{*}{ Total } \\
\hline & & $\begin{array}{c}\text { Zero } \\
\text { Vehicles }\end{array}$ & $\begin{array}{c}\text { Vehicles } \\
< \\
\text { Workers } \\
\text { (inadequate } \\
\text { vehicles) }\end{array}$ & $\begin{array}{c}\text { Vehicles } \\
>= \\
\text { Workers } \\
\text { (adequate } \\
\text { vehicles) }\end{array}$ & \\
\hline \multirow{8}{*}{ Florida } & POV driver & $0.5 \%$ & $4.7 \%$ & $94.8 \%$ & $100.0 \%$ \\
\hline & POV passenger & $0.6 \%$ & $7.7 \%$ & $91.7 \%$ & $100.0 \%$ \\
\hline & Transit & $45.6 \%$ & $8.3 \%$ & $46.1 \%$ & $100.0 \%$ \\
\hline & Walk & $9.3 \%$ & $5.0 \%$ & $85.7 \%$ & $100.0 \%$ \\
\hline & Bike & $10.5 \%$ & $6.1 \%$ & $83.4 \%$ & $100.0 \%$ \\
\hline & Other & $13.6 \%$ & $10.8 \%$ & $75.6 \%$ & $100.0 \%$ \\
\hline & All modes & $2.3 \%$ & $5.5 \%$ & $92.1 \%$ & $100.0 \%$ \\
\hline & Population & $4.6 \%$ & $5.4 \%$ & $90.1 \%$ & $100.0 \%$ \\
\hline \multirow{8}{*}{ U.S. } & POV driver & $0.4 \%$ & 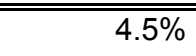 & $95.0 \%$ & $\overline{100.0 \%}$ \\
\hline & POV passenger & $0.6 \%$ & $6.7 \%$ & $92.7 \%$ & $100.0 \%$ \\
\hline & Transit & $48.5 \%$ & $17.1 \%$ & $34.4 \%$ & $100.0 \%$ \\
\hline & Walk & $16.5 \%$ & $8.9 \%$ & $74.6 \%$ & $100.0 \%$ \\
\hline & Bike & $10.1 \%$ & $8.5 \%$ & $81.4 \%$ & $100.0 \%$ \\
\hline & Other & $13.8 \%$ & $6.9 \%$ & $79.3 \%$ & $100.0 \%$ \\
\hline & All modes & $3.7 \%$ & $5.8 \%$ & $90.5 \%$ & $100.0 \%$ \\
\hline & Population & $6.1 \%$ & $5.7 \%$ & $88.2 \%$ & $100.0 \%$ \\
\hline
\end{tabular}

\section{Florida}

Florida has a smaller share of persons in zero-vehicle households or households with inadequate vehicles than the U.S. as a whole. Persons in zero-vehicle households are 4.6 percent of the total population in Florida vs. 6.1 percent in the U.S. Persons from households with inadequate vehicles are 5.4 percent of the total population in Florida vs. 5.7 percent in the U.S.

Persons in zero-vehicle households in Florida travel less than the average person to a larger degree than those in the U.S. as a whole. While this segment makes up 4.6 percent of the total population, it makes only 2.3 percent of the total travel by all modes in Florida. While similar to their U.S. counterparts in that they make about 1 percent of their travel by POV driving or riding, the degree to which they use the other modes more than the average person is higher in Florida than in the U.S. Consider transit, for example: zero-vehicle households use transit almost 10 times as much as the average person in Florida vs. 8 times for the U.S.

Persons in zero-vehicle households or households with inadequate vehicles represent a large market for transit in Florida, but not as large as in the U.S. Persons in zero-vehicle households 
make up 45.6 percent and persons with inadequate vehicles make up 8.3 percent of the total transit market, a combined market size of 53.9 percent vs. 65.6 percent in the U.S.

\subsubsection{Modal Share}

Table 3.12 shows results of modal share for segments by vehicle availability for Florida and the U.S.

U.S.

Persons in zero-vehicle households drive or ride as a POV passenger about one-tenth of the time, with another 3.0 percent by biking. They primarily rely on walking (48.6\%) and transit (26.7\%). The importance of transit for them is not only in their absolute share of all transit travel (48.5\%) but also in their overwhelming dominance of POVs as major motorized modes for travel. It is surprising that they do not bike more for many of the trips they currently take by walking.

Table 3.12. Modal Share for Segments by Vehicle Availability

\begin{tabular}{|c|c|c|c|c|c|}
\hline \multirow[b]{2}{*}{$\begin{array}{l}\text { Florida } \\
\text { vs. U.S. }\end{array}$} & \multirow[b]{2}{*}{ Main Modes } & \multicolumn{3}{|c|}{ Vehicles Relative to Workers } & \multirow[b]{2}{*}{ Total } \\
\hline & & $\begin{array}{c}\text { Zero } \\
\text { Vehicles }\end{array}$ & $\begin{array}{c}\text { Vehicles } \\
< \\
\text { Workers } \\
\text { (inadequate } \\
\text { vehicles) }\end{array}$ & $\begin{array}{c}\text { Vehicles } \\
\text { >= } \\
\text { Workers } \\
\text { (adequate } \\
\text { vehicles) }\end{array}$ & \\
\hline \multirow{7}{*}{ Florida } & POV driver & $14.1 \%$ & $56.3 \%$ & $68.0 \%$ & $66.1 \%$ \\
\hline & POV passenger & $5.3 \%$ & $26.9 \%$ & $19.2 \%$ & $19.3 \%$ \\
\hline & Transit & $20.9 \%$ & $1.6 \%$ & $0.5 \%$ & $1.1 \%$ \\
\hline & Walk & $38.5 \%$ & $8.7 \%$ & $8.9 \%$ & $9.6 \%$ \\
\hline & Bike & $6.0 \%$ & $1.5 \%$ & $1.2 \%$ & $1.3 \%$ \\
\hline & Other & $15.2 \%$ & $5.1 \%$ & $2.1 \%$ & $2.6 \%$ \\
\hline & All modes & $100.0 \%$ & $100.0 \%$ & $100.0 \%$ & $100.0 \%$ \\
\hline \multirow{7}{*}{ U.S. } & POV driver & $7.6 \%$ & $49.6 \%$ & $66.9 \%$ & $63.7 \%$ \\
\hline & POV passenger & $3.0 \%$ & $22.2 \%$ & $19.6 \%$ & $19.1 \%$ \\
\hline & Transit & $26.7 \%$ & $6.1 \%$ & $0.8 \%$ & $2.1 \%$ \\
\hline & Walk & $48.6 \%$ & $16.9 \%$ & $9.1 \%$ & $11.0 \%$ \\
\hline & Bike & $3.0 \%$ & $1.6 \%$ & $1.0 \%$ & $1.1 \%$ \\
\hline & Other & $11.0 \%$ & $3.5 \%$ & $2.6 \%$ & $3.0 \%$ \\
\hline & All modes & $100.0 \%$ & $100.0 \%$ & $100.0 \%$ & $100.0 \%$ \\
\hline
\end{tabular}

Modal choices differ significantly between households with inadequate vehicles and zero-vehicle households. Persons with inadequate vehicles rely on POVs far more than persons with zero vehicles. They drive about one-half of the time (49.6\%) and ride as a POV passenger more than one-fifth of the time (22.2\%). At the same time, they are less likely to use the other modes than persons with zero vehicles.

\section{Florida}

Persons with zero vehicles in Florida drive or ride as a POV passenger almost one-fifth of the time (19.4\%), almost twice as much as those in the U.S. as a whole $(10.6 \%)$. They bike more but walk 
and use transit less often than their counterparts in the U.S. as a whole. Transit, however, still serves more than one-fifth of their travel $(20.9 \%)$.

\subsection{Frequency of Transit Use}

A basic strategy for transit operators to grow their ridership is to increase the frequency of transit use by existing customers. To effectively execute this strategy requires a good understanding of the various segments of existing customers by their current frequency of transit use. The current study defines three travel segments for regular users based on information from the 2009 NHTS on the reported monthly frequency of transit use:

- Use 1-9 times per month (least frequent users)

- Use 10-29 times per month (users with medium frequency)

- Use 30+ times per month (most frequent users)

In addition, the current study also includes two travel segments for persons who did not use transit during the one-month period prior to the travel day:

- Non-user - transit available but not used

- Transit not available - transit not available

It should be noted that the information on monthly frequency of transit use relates to the month immediately before the designated travel day for each household in the 2009 NHTS sample. In contrast, transit travel of primary interest to the current study relates to travel done on the travel day. As a result, it is possible that a respondent may not use transit any time during the month proceeding his travel day, but may still use transit on the travel day. The opposite can also be possible, i.e., a respondent may have used transit at least once during the month but may not use transit on his travel day.

\subsubsection{Market Size}

Table 3.13 presents results on market size for segments based on the monthly frequency of transit use for each mode and for Florida and the U.S.

\section{U.S.}

The most frequent users, persons with medium frequency, and the least frequent users represent $3.0,4.6$, and 11.3 percent of the total population, respectively, for a total of 18.9 percent of the overall population using transit during an average month. The remainder of the population is split between non-users $(60.2 \%)$ and people without transit service available $(20.9 \%)$.

The most frequent users of transit (30+ times per month) travel more by all modes combined than the average person in the population, with 3.2 percent of all travel and 3.0 percent of the total 
population. The less frequent users of transit travel less by all modes combined than the average person, as do persons without transit service available, making 17.1 percent of all travel but with 20.9 percent of the population.

The most frequent users of transit capture 43.4 percent of the overall transit market. With their share of the population at 3.0 percent, they use transit nearly 15 times as much as the average person in the population. The medium-frequency users capture 35.0 percent of the overall transit market. With their population share at 4.6 percent, they use transit more than 7 times as much as the average person.

\section{Florida}

For Florida, each of the three segments of transit users represents a smaller share of the overall population than the U.S., with 12.0 percent of the overall population using transit during an average month. In addition, Florida has a larger share of the population that does not use transit during an average month $(69.3 \%$ vs. $60.2 \%)$, while it has a smaller share of the population that is not served by transit (18.8\% vs. $20.9 \%)$.

Table 3.13. Market Size for Segments by Frequency of Transit Use

\begin{tabular}{|c|c|c|c|c|c|c|c|}
\hline \multirow[b]{2}{*}{$\begin{array}{l}\text { Florida vs. } \\
\text { U.S. }\end{array}$} & \multirow[b]{2}{*}{ Main Modes } & \multicolumn{5}{|c|}{ Monthly Frequency of Transit Use } & \multirow[b]{2}{*}{ Total } \\
\hline & & $\begin{array}{c}30+ \\
\text { Times/ } \\
\text { Month } \\
\text { (most } \\
\text { frequent } \\
\text { user) }\end{array}$ & $\begin{array}{c}\text { 10-29 } \\
\text { Times/ } \\
\text { Month } \\
\text { (medium } \\
\text { frequency) }\end{array}$ & $\begin{array}{c}1-9 \\
\text { Times/ } \\
\text { Month } \\
\text { (least } \\
\text { frequent } \\
\text { user) }\end{array}$ & $\begin{array}{l}\text { Non- } \\
\text { User } \\
\text { (0 times/ } \\
\text { month) }\end{array}$ & $\begin{array}{c}\text { Transit } \\
\text { Not } \\
\text { Available }\end{array}$ & \\
\hline \multirow{8}{*}{ Florida } & POV driver & $0.6 \%$ & $1.1 \%$ & $7.8 \%$ & $90.4 \%$ & $0.1 \%$ & $100.0 \%$ \\
\hline & POV passenger & $0.3 \%$ & $1.7 \%$ & $5.0 \%$ & $43.8 \%$ & $49.2 \%$ & $100.0 \%$ \\
\hline & Transit & $43.1 \%$ & $34.5 \%$ & $18.3 \%$ & $0.1 \%$ & $4.0 \%$ & $100.0 \%$ \\
\hline & Walk & $4.4 \%$ & $4.0 \%$ & $12.4 \%$ & $61.2 \%$ & $18.0 \%$ & $100.0 \%$ \\
\hline & Bike & $7.5 \%$ & $2.1 \%$ & $9.8 \%$ & $49.5 \%$ & $31.0 \%$ & $100.0 \%$ \\
\hline & Other & $2.6 \%$ & $2.8 \%$ & $7.2 \%$ & $27.9 \%$ & $59.6 \%$ & $100.0 \%$ \\
\hline & All modes & $1.7 \%$ & $2.0 \%$ & $7.8 \%$ & $73.9 \%$ & $14.6 \%$ & $100.0 \%$ \\
\hline & Population & $1.6 \%$ & $2.5 \%$ & $7.9 \%$ & $69.3 \%$ & $18.8 \%$ & $100.0 \%$ \\
\hline \multirow{8}{*}{ U.S. } & POV driver & $1.2 \%$ & $2.8 \%$ & $12.9 \%$ & $82.9 \%$ & $0.2 \%$ & $100.0 \%$ \\
\hline & POV passenger & $1.0 \%$ & $2.5 \%$ & $6.3 \%$ & $36.3 \%$ & $54.0 \%$ & $100.0 \%$ \\
\hline & Transit & $43.4 \%$ & $35.0 \%$ & $13.0 \%$ & $0.3 \%$ & $8.3 \%$ & $100.0 \%$ \\
\hline & Walk & $8.0 \%$ & $10.8 \%$ & $18.8 \%$ & $42.1 \%$ & $20.4 \%$ & $100.0 \%$ \\
\hline & Bike & $3.4 \%$ & $6.4 \%$ & $12.5 \%$ & $31.8 \%$ & $45.9 \%$ & $100.0 \%$ \\
\hline & Other & $3.9 \%$ & $5.7 \%$ & $8.1 \%$ & $20.1 \%$ & $62.2 \%$ & $100.0 \%$ \\
\hline & All modes & $3.2 \%$ & $4.7 \%$ & $12.0 \%$ & $63.0 \%$ & $17.1 \%$ & $100.0 \%$ \\
\hline & Population & $3.0 \%$ & $4.6 \%$ & $11.3 \%$ & $60.2 \%$ & $20.9 \%$ & $100.0 \%$ \\
\hline
\end{tabular}

\subsubsection{Modal Share}

Table 3.14 shows the results of modal share for each segment defined on the basis of monthly frequency of transit use for Florida and the U.S. 


\section{U.S.}

The most frequent users of transit (30+ times/month) make 35.0 percent of their trips by transit, 30.0 percent by walking, 22.9 percent by driving a POV, 6.4 percent by riding as a POV passenger, and the rest by other modes. The medium-frequency users (10-29 times per month) drive more $(35.3 \%$ vs. $22.9 \%)$ and riding as a POV passenger more $(11.4 \%$ vs. $6.4 \%)$, but use transit less $(19.4 \%$ vs. $35.0 \%)$. The least frequent users (1-9 times per month) drive significantly more $(63.4 \%$ vs. $22.9 \%$ ), but walk significantly less (18.9\%) and use transit for just 2.8 percent of their overall travel.

\section{Florida}

In Florida, there are two notable differences from the U.S. The most frequent users of transit bike for more of their travel (6.9\% vs. $1.3 \%)$, and the medium-frequency users do more of their travel by riding as a POV passenger (18.0\% vs. $11.4 \%$ ) and by transit (23.4 vs. $19.4 \%)$ but do less of their travel by walking $(19.7 \%$ vs. $27.9 \%)$. The least frequent users are similar between Florida and the U.S. as a whole.

Table 3.14. Modal Shares for Segments by Frequency of Transit Use

\begin{tabular}{|c|c|c|c|c|c|c|c|}
\hline \multirow[b]{2}{*}{$\begin{array}{l}\text { Florida } \\
\text { vs. } \\
\text { U.S. }\end{array}$} & \multirow[b]{2}{*}{ Main Modes } & \multicolumn{5}{|c|}{ Monthly Frequency of Transit Use } & \multirow[b]{2}{*}{ Total } \\
\hline & & $\begin{array}{c}30+ \\
\text { Times/ } \\
\text { Month } \\
\text { (most } \\
\text { frequent } \\
\text { user) }\end{array}$ & $\begin{array}{c}\text { 10-29 } \\
\text { Times/ } \\
\text { Month } \\
\text { (medium } \\
\text { frequency) }\end{array}$ & $\begin{array}{c}\text { 1-9 } \\
\text { Times/ } \\
\text { Month } \\
\text { (least } \\
\text { frequent } \\
\text { user) }\end{array}$ & $\begin{array}{l}\text { Non- } \\
\text { User } \\
\text { (0 times/ } \\
\text { month) }\end{array}$ & $\begin{array}{c}\text { Transit } \\
\text { Not } \\
\text { Available }\end{array}$ & \\
\hline \multirow{7}{*}{ Florida } & POV driver & $22.7 \%$ & $33.1 \%$ & $62.8 \%$ & $77.0 \%$ & $0.4 \%$ & $62.9 \%$ \\
\hline & POV passenger & $4.1 \%$ & $18.0 \%$ & $13.6 \%$ & $12.6 \%$ & $71.6 \%$ & $21.3 \%$ \\
\hline & Transit & $35.3 \%$ & $23.4 \%$ & $3.2 \%$ & $0.0 \%$ & $0.4 \%$ & $1.4 \%$ \\
\hline & Walk & $26.4 \%$ & $19.7 \%$ & $15.7 \%$ & $8.2 \%$ & $12.2 \%$ & $9.9 \%$ \\
\hline & Bike & $6.9 \%$ & $1.6 \%$ & $1.9 \%$ & $1.0 \%$ & $3.2 \%$ & $1.5 \%$ \\
\hline & Other & $4.6 \%$ & $4.2 \%$ & $2.7 \%$ & $1.1 \%$ & $12.2 \%$ & $3.0 \%$ \\
\hline & All modes & $100.0 \%$ & $100.0 \%$ & $100.0 \%$ & $100.0 \%$ & $100.0 \%$ & $100.0 \%$ \\
\hline \multirow{7}{*}{ U.S. } & POV driver & $22.9 \%$ & $35.3 \%$ & $63.4 \%$ & $777.9 \%$ & $0.6 \%$ & 59.2\% \\
\hline & POV passenger & $6.4 \%$ & $11.4 \%$ & $11.1 \%$ & $12.2 \%$ & $67.1 \%$ & $21.2 \%$ \\
\hline & Transit & $35.0 \%$ & $19.4 \%$ & $2.8 \%$ & $0.0 \%$ & $1.3 \%$ & $2.6 \%$ \\
\hline & Walk & $30.0 \%$ & $27.9 \%$ & $18.9 \%$ & $8.1 \%$ & $14.5 \%$ & $12.1 \%$ \\
\hline & Bike & $1.3 \%$ & $1.7 \%$ & $1.3 \%$ & $0.6 \%$ & $3.4 \%$ & $1.3 \%$ \\
\hline & Other & $4.4 \%$ & $4.4 \%$ & $2.4 \%$ & $1.2 \%$ & $13.2 \%$ & $3.6 \%$ \\
\hline & All modes & $100.0 \%$ & $100.0 \%$ & $100.0 \%$ & $100.0 \%$ & $100.0 \%$ & $100.0 \%$ \\
\hline
\end{tabular}

\subsection{Purpose of Person Trips}

The current study focuses on three purposes that are essential to sustain daily life: work and workrelated, school, and medical/dental. In addition, a large portion of travel to or from work and school occurs during periods when roads are heavily used. 


\subsubsection{Market Size}

Table 3.15 presents results of market size for purpose-based segments for each mode and for Florida and the U.S.

U.S.

Except for school bus (in the Other modal group), transit plays the largest role in serving the three essential purpose-based markets among all modes. Overall for all modes combined, slightly less than one-third of all household travel is made for these three purposes. Just over one-third of POV driving is for these purposes. About one-fifth of all walk trips, all biking trips, and all trips by POV riding serve these three purposes. In contrast, more than one-half of all transit trips are made for these three purposes, with 36.3 percent for work, 8.9 percent for school, and 5.8 percent for medical/dental services.

Table 3.15. Market Size for Segments by Trip Purpose

\begin{tabular}{|l|l|r|r|r|r|r|}
\hline \multirow{2}{*}{$\begin{array}{l}\text { Florida vs. } \\
\text { U.S. }\end{array}$} & Main Modes & $\begin{array}{c}\text { Work \& } \\
\text { Work- } \\
\text { Related }\end{array}$ & School & $\begin{array}{c}\text { Medical/ } \\
\text { Dental }\end{array}$ & \multirow{2}{*}{ Other } & \\
\hline \multirow{4}{*}{ Florida } & POV driver & $29.3 \%$ & $1.9 \%$ & $3.6 \%$ & $65.2 \%$ & $100.0 \%$ \\
& POV passenger & $4.8 \%$ & $11.0 \%$ & $5.3 \%$ & $78.9 \%$ & $100.0 \%$ \\
& Transit & $27.4 \%$ & $8.5 \%$ & $8.2 \%$ & $55.9 \%$ & $100.0 \%$ \\
& Walk & $7.3 \%$ & $4.2 \%$ & $0.7 \%$ & $87.8 \%$ & $100.0 \%$ \\
& Bike & $8.0 \%$ & $8.5 \%$ & $0.8 \%$ & $82.8 \%$ & $100.0 \%$ \\
& Other & $11.1 \%$ & $56.7 \%$ & $6.1 \%$ & $26.0 \%$ & $100.0 \%$ \\
\cline { 2 - 6 } & All modes & $21.7 \%$ & $5.4 \%$ & $3.7 \%$ & $69.1 \%$ & $100.0 \%$ \\
\hline \hline \multirow{5}{*}{ U.S. } & POV driver & $29.8 \%$ & $1.9 \%$ & $2.8 \%$ & $65.4 \%$ & $100.0 \%$ \\
& POV passenger & $4.5 \%$ & $10.3 \%$ & $3.8 \%$ & $81.4 \%$ & $100.0 \%$ \\
& Transit & $36.3 \%$ & $8.9 \%$ & $5.8 \%$ & $49.0 \%$ & $100.0 \%$ \\
& Walk & $12.3 \%$ & $6.3 \%$ & $1.1 \%$ & $80.4 \%$ & $100.0 \%$ \\
& Bike & $14.0 \%$ & $4.4 \%$ & $0.2 \%$ & $81.3 \%$ & $100.0 \%$ \\
& Other & $9.6 \%$ & $61.3 \%$ & $3.6 \%$ & $25.5 \%$ & $100.0 \%$ \\
\cline { 2 - 6 } & All modes & $22.4 \%$ & $5.9 \%$ & $2.9 \%$ & $68.8 \%$ & $100.0 \%$ \\
\hline
\end{tabular}

\section{Florida}

Work and school capture slightly smaller shares in Florida than the U.S., but medical/dental purposes capture a larger share of overall travel. These differences are consistent with the fact that older adults represent a much larger portion of the population in Florida than the U.S. as a whole.

Except for walking, medical/dental travel captures a larger share of travel by each of the identified modes in Florida than in the U.S. Another notable difference with the U.S. is that work and related 
travel captures significantly smaller shares of travel by transit $(27.4 \%$ vs. $36.3 \%)$, walking $(7.3 \%$ vs. $12.3 \%)$, and biking $(8.0 \%$ vs. $14.0 \%)$.

\subsubsection{Modal Share}

Table 3.16 presents results of modal share for each purpose-based segment for both Florida and the U.S.

\section{U.S.}

The modal choices for these three purpose-based segments differ dramatically. POV driving dominates travel for work purposes, with a share of 84.8 percent. The other modes' share of work travel is 6.0 percent for walking, 3.9 percent for POV riding, and 3.3 percent for transit. POV riding plays a significantly greater role for school and medical/dental trips than for work trips, with 3.9 percent for work, 33.1 percent for school, and 24.9 percent for medical/dental purposes. Transit plays a slightly smaller role for school travel but a larger role for medical/ dental travel than for work purposes. Walking is twice as often for school travel than for work, but less often for medical/dental purposes than for work.

Table 3.16. Modal Shares for Segments by Trip Purpose

\begin{tabular}{|l|l|r|r|r|r|r|}
\hline \multirow{2}{*}{$\begin{array}{l}\text { Florida } \\
\text { vs. U.S. }\end{array}$} & Main Modes & \multicolumn{3}{|c|}{ Purpose of Person Trips } & \multirow{2}{*}{ Total } \\
\cline { 2 - 6 } & $\begin{array}{c}\text { Work \& } \\
\text { Work } \\
\text { Related }\end{array}$ & School & $\begin{array}{c}\text { Medical } \\
\text { \& Dental }\end{array}$ & Other & \\
\hline \multirow{5}{*}{ Florida } & POV driver & $89.3 \%$ & $23.1 \%$ & $64.0 \%$ & $62.4 \%$ & $66.2 \%$ \\
& POV passenger & $4.3 \%$ & $38.9 \%$ & $27.3 \%$ & $22.0 \%$ & $19.3 \%$ \\
& Transit & $1.3 \%$ & $1.7 \%$ & $2.3 \%$ & $0.9 \%$ & $1.1 \%$ \\
& Walk & $3.2 \%$ & $7.3 \%$ & $1.9 \%$ & $12.1 \%$ & $9.6 \%$ \\
& Bike & $0.5 \%$ & $2.1 \%$ & $0.3 \%$ & $1.6 \%$ & $1.3 \%$ \\
& Other & $1.3 \%$ & $27.0 \%$ & $4.2 \%$ & $1.0 \%$ & $2.6 \%$ \\
\cline { 2 - 6 } & All modes & $100.0 \%$ & $100.0 \%$ & $100.0 \%$ & $100.0 \%$ & $100.0 \%$ \\
\hline \hline \multirow{5}{*}{ U.S. } & POV driver & $84.8 \%$ & $20.5 \%$ & $63.1 \%$ & $60.7 \%$ & $63.8 \%$ \\
& POV passenger & $3.9 \%$ & $33.1 \%$ & $24.9 \%$ & $22.6 \%$ & $19.1 \%$ \\
& Transit & $3.3 \%$ & $3.1 \%$ & $4.1 \%$ & $1.5 \%$ & $2.0 \%$ \\
& Walk & $6.0 \%$ & $11.6 \%$ & $4.1 \%$ & $12.9 \%$ & $11.0 \%$ \\
& Bike & $0.7 \%$ & $0.8 \%$ & $0.1 \%$ & $1.3 \%$ & $1.1 \%$ \\
& Other & $1.3 \%$ & $30.8 \%$ & $3.7 \%$ & $1.1 \%$ & $3.0 \%$ \\
\cline { 2 - 6 } & All modes & $100.0 \%$ & $100.0 \%$ & $100.0 \%$ & $100.0 \%$ & $100.0 \%$ \\
\hline
\end{tabular}

\section{Florida}

The general pattern of modal choices across the purpose-based segments is similar between Florida and the U.S. as a whole. However, Florida is more reliant on POV driving and riding but less reliant on transit and walking. In addition, the proportional difference in transit's role in serving each of these purpose-based segments between Florida and the U.S. is particularly larger for work purposes than for school or medical/dental purposes. Overall, for all purposes combined (the last column), transit serves 1.1 percent of all trips in Florida vs. 2.0 percent in the U.S. as a whole. That 
is, transit's modal share for all purposes in Florida is slightly more than one half of that in the U.S. For school travel, transit's modal share is 1.7 percent in Florida vs. 3.1 percent in the U.S. For medical/dental travel, transit's mode share is 2.3 percent in Florida vs. 4.1 percent in the U.S. In both cases, transit's modal share in Florida is more than one half of that in the U.S. For work travel, however, transit's modal share is only 1.3 percent in Florida vs. 3.3 percent in the U.S.

\subsection{Summary}

Some results from this section are summarized here for a number of key markets in a graphic format for Florida and the U.S. The summary focuses on five aspects:

- Users and non-users (Figure 3.1)

- Relative mobility between each market and the average person (Figure 3.2)

- Share of transit trips captured by each market (Figure 3.3)

- Transit's modal share within each market (Figure 3.4)

- Modal shares across all modes within each market (Figure 3.5)

These key markets include:

- Non-drivers

- New immigrants

- Persons with medical conditions

- Hispanics

- Non-Hispanic Blacks

- Income under $\$ 15,000$

- Zero-vehicle households

- Most frequent users

- Work purposes

\subsubsection{User Status and Service Availability}

During an average month, about 19 percent of the U.S. population use transit at least once (Figure 3.1). Just over 60 percent of the population considers transit service as being available to them but chooses not to use transit at all during an average month. The remaining 21 percent of the population believes that transit service is not available to them.

More people in Florida believe that transit service is available but fewer use it. About 18.8 percent of the Florida population, slightly smaller than the U.S. share, believes that service is not available to them. The rest of the population thinks that service is available, but only 11.9 percent uses transit during an average month and the other 69.3 percent do not use transit at all. 


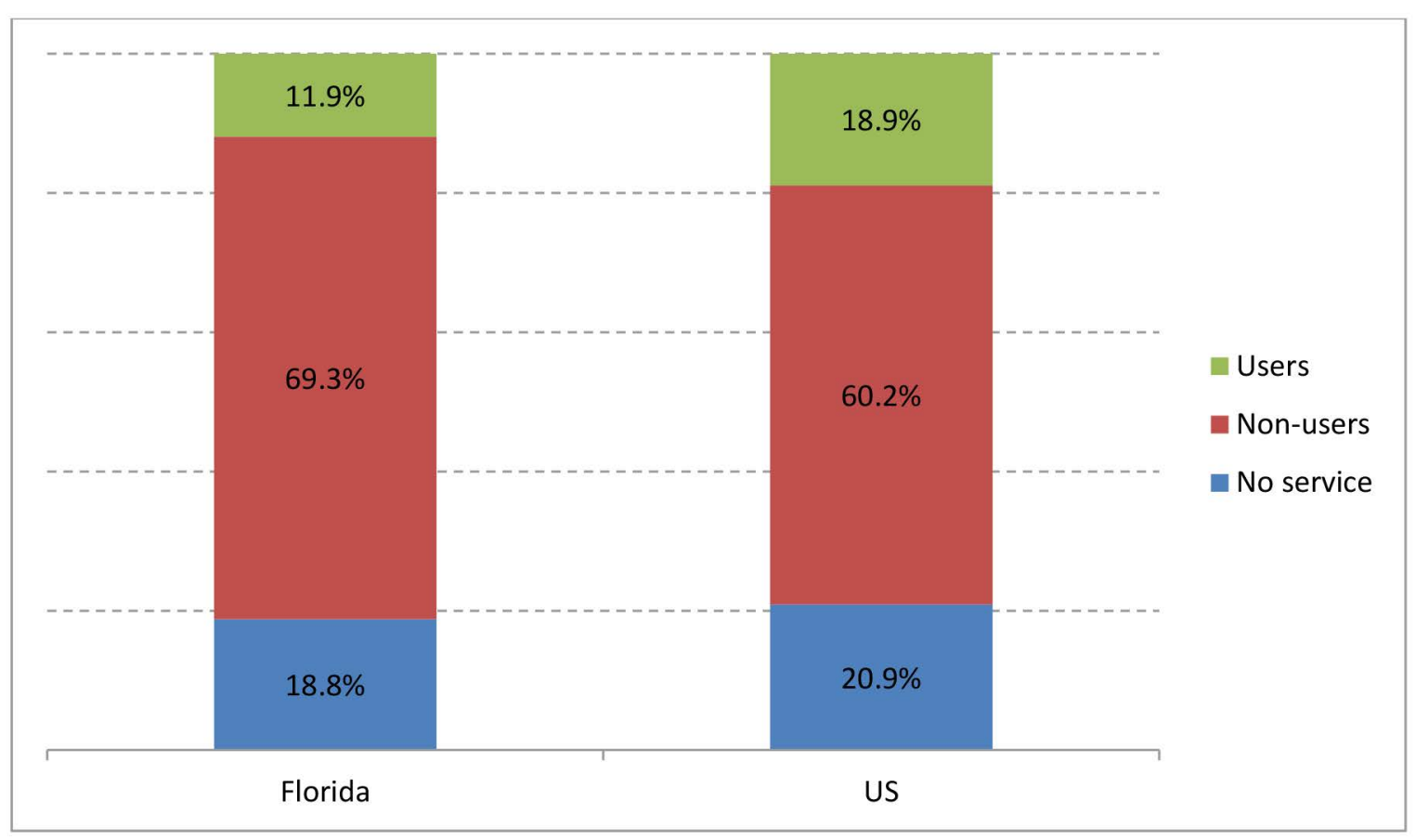

Figure 3.1. Population Distribution by User Status and Service Availability

\subsubsection{Market Size}

These key markets represent a range of market size for transit (Figure 3.2). For the U.S. as a whole, persons in zero-vehicle households and the most frequent users of transit $(30+$ times per month) capture more than 40 percent of the overall transit market, respectively. Work trips are more than 36 percent of the overall transit market. Hispanics, Non-Hispanic Blacks, and persons with household income under $\$ 15,000$ capture about 30 percent of the overall transit market. The other three markets represent significantly smaller markets for transit.

Persons with zero vehicles, the most frequent users, non-drivers, and new immigrants represent market sizes that are similar between Florida and the U.S. Work trips, however, are a significantly smaller market for transit in Florida than in the U.S. as a whole. On the other hand, new immigrants, persons with household income under \$15,000, Hispanics, and Non-Hispanic Blacks represent transit markets that are larger in Florida than in the U.S., particularly Hispanics and new immigrants. 


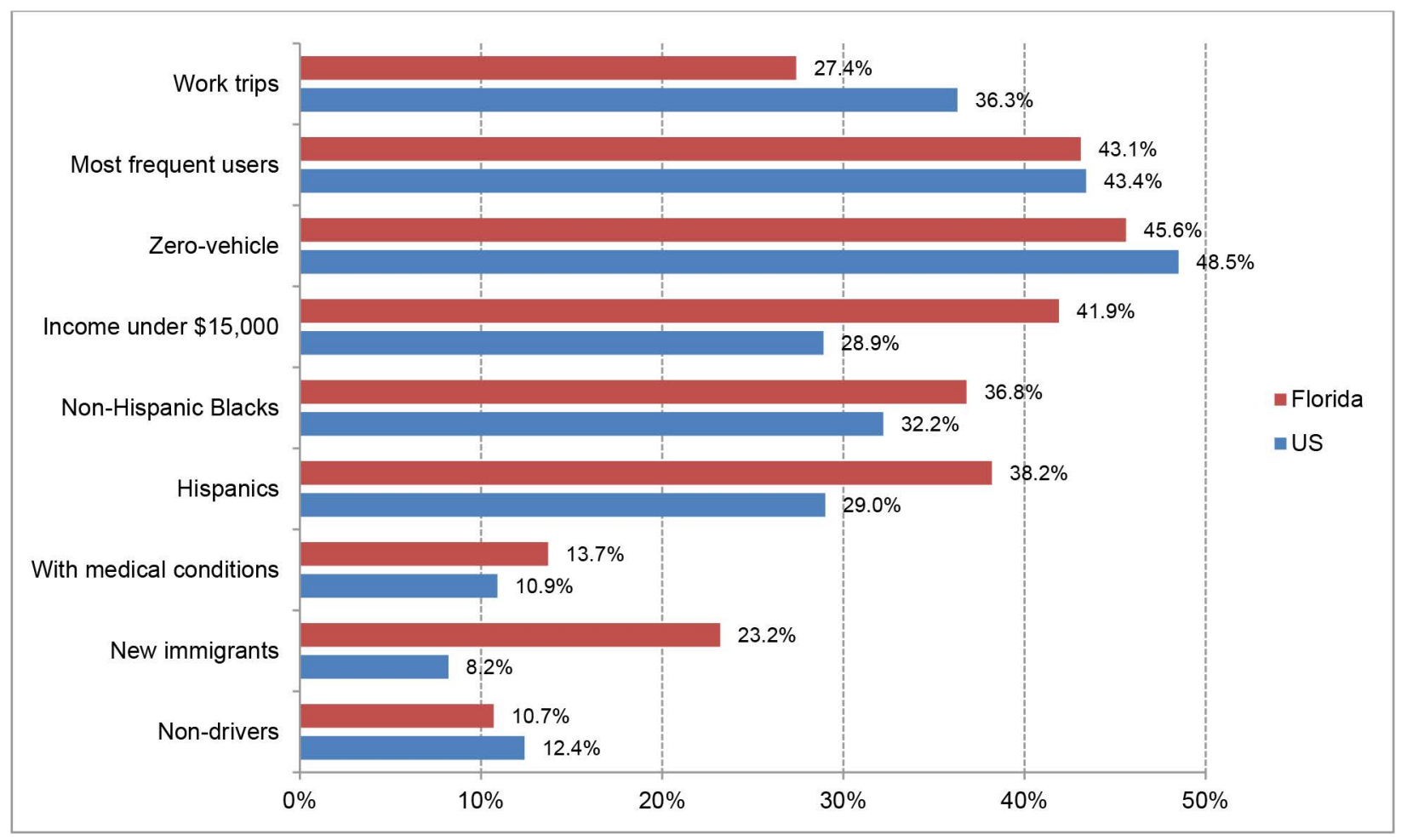

Figure 3.2. Size of Transit Markets

\subsubsection{Transit's Modal Share}

The role of transit in each key market varies dramatically for the U.S. (Figure 3.3). The most frequent users of transit (30+ times per month) rely on transit for more than one-third of their total travel. Persons without a vehicle use transit more than one-quarter of the time. The role of transit is well under 10 percent for persons with household income under $\$ 15,000$, Non-Hispanic Blacks, and new immigrants. Those who travel for work trips, Hispanics, persons with medical conditions, and non-drivers depend even less on transit, with a transit modal share under 5 percent.

The overall pattern of transit's role in serving these key markets is similar between Florida and the U.S. Transit's modal share for the most frequent users of transit is similar between Florida and the U.S. with the modal share for Florida slightly higher. However, transit plays a smaller role in each of the other key markets in Florida than in the U.S. as a whole.

\subsubsection{Modal Distribution}

Figure 3.4 shows the modal distribution for each of the key markets for Florida and the U.S. For the U.S., POV driving and riding dominate all other modes for work trips, with a total share of 88.7 percent. POV driving and riding serve around three-quarters of all person-trips for new immigrants, persons with medical conditions, Hispanics, and Non-Hispanic Blacks. They serve two-thirds of the travel for persons with household income under $\$ 15,000$. Non-drivers rely on POV riding for onehalf of their travel. The role of POVs is 29.3 percent for the most frequent users and 10.6 percent for persons in zero-vehicle households. 


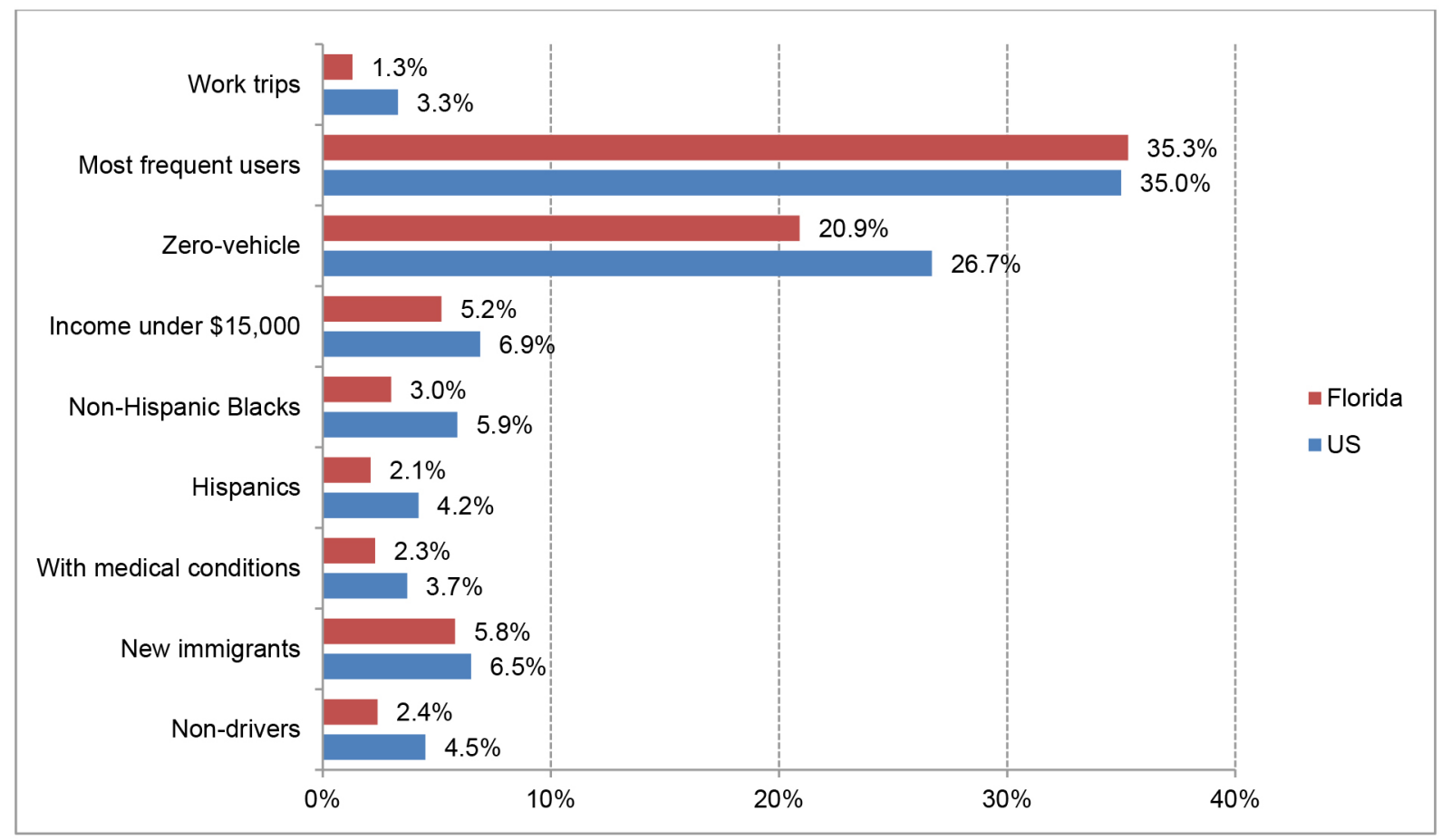

Figure 3.3. Transit's Modal Share within Each Market

Walking plays a significant role for most of the key markets. Its modal shares are 48.6 percent for persons in zero-vehicle households, about 30 percent for non-drivers and the most frequent transit users, 19.5 percent for persons with household income under $\$ 15,000$, and a range of 12.8-17.0 percent for persons with medical conditions, Non-Hispanic Blacks, Hispanics, and new immigrants. Walking captures only 6.0 percent of all work trips.

Biking serves no greater than 3.0 percent of all travel for any of these key markets. This is true even for those markets whose modal share of walking is as high as 30 percent (non-drivers and the most frequent users of transit) or nearly 50 percent (zero-vehicle households).

Transit plays a minor role even for some of the markets that are traditionally considered to be transit dependent. For example, transit's modal share is 4.5 percent among non-drivers and 6.9 percent among persons in households with income under $\$ 15,000$.

Again, the overall pattern of modal shares across these key markets is similar between Florida and the U.S. A notable difference is that except for the most frequent users of transit, the other key markets in Florida rely slightly more on POV driving and riding but significantly less on transit and walking. 


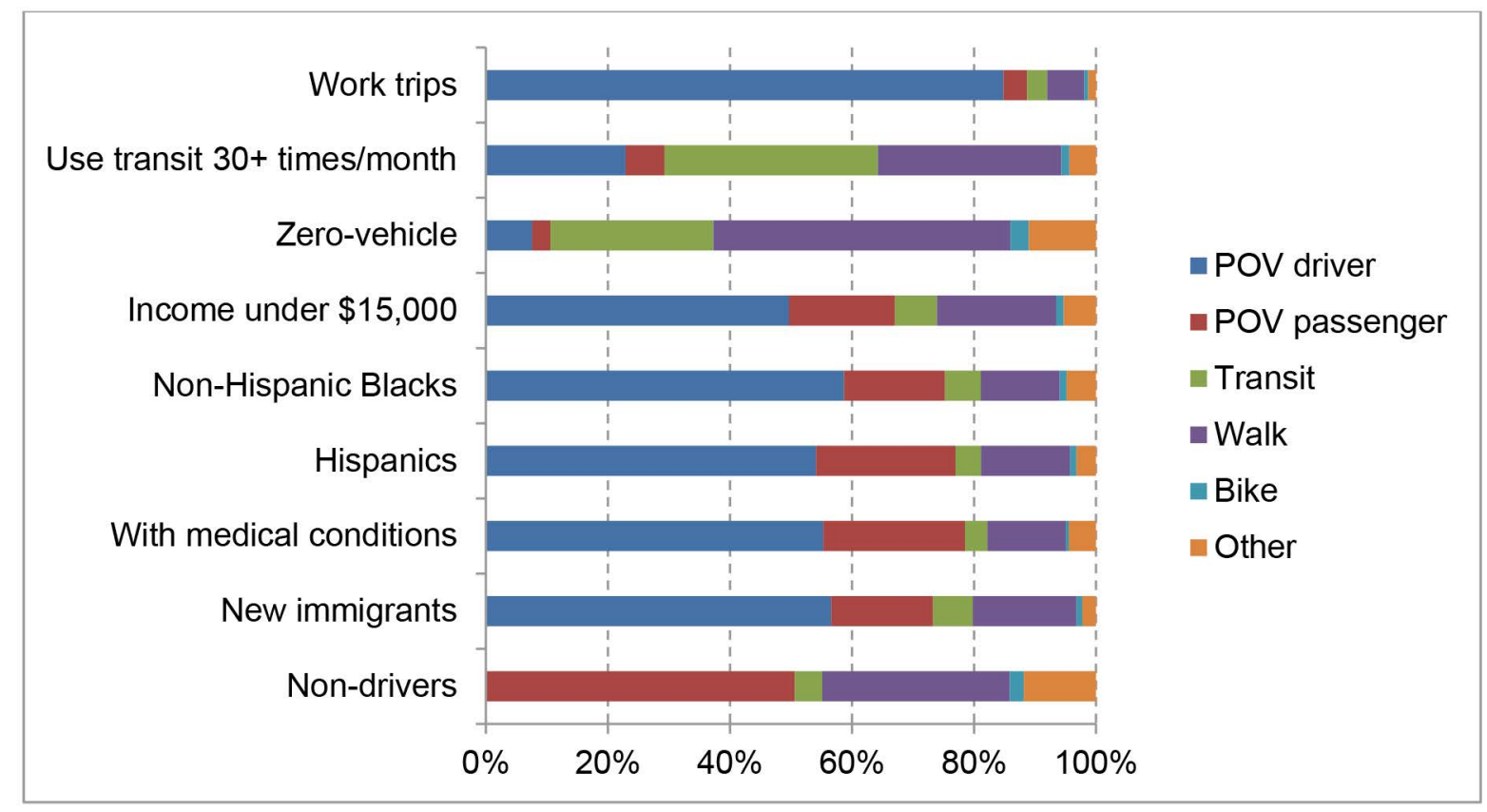

\section{U.S.}

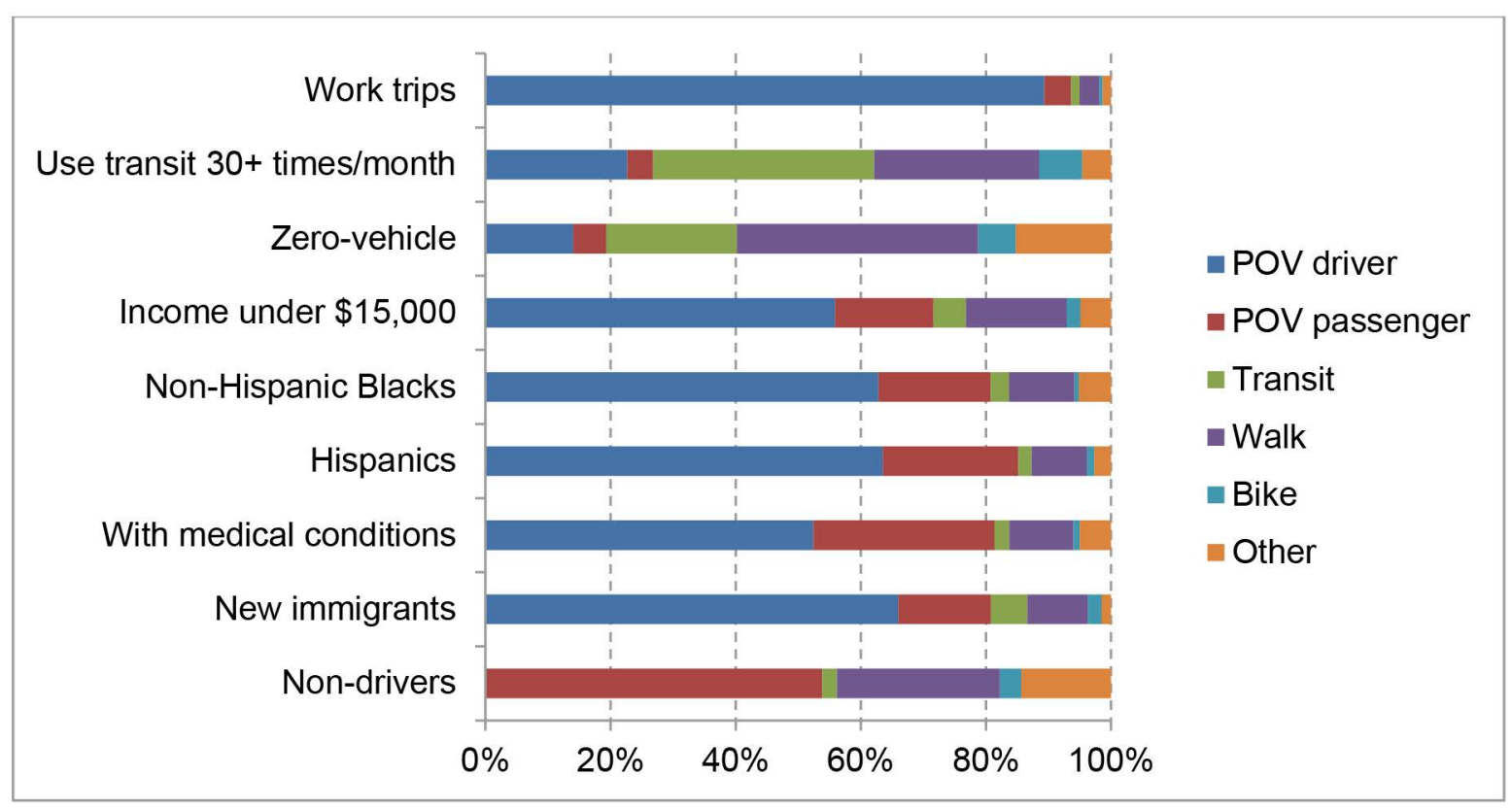

Florida

Figure 3.4. Modal Shares within Each Travel Segment

\subsubsection{Relative General Mobility}

The amount of travel by all modes varies significantly across the key markets. Figure 3.5 shows the level of relative general mobility for each key market. For a given market, its relative general mobility is the ratio of its share of the total travel by all modes over its share of the total population. The most frequent users of transit are the only key market that travels more than the average person. Persons in all other key markets travel less than the average person in the total population. 
New immigrants, Hispanics, and Non-Hispanic Blacks travel about 90 percent of what the average person in the total population travels. Persons with annual household income under $\$ 15,000$ travel about 75 percent of what the average person travels. Persons with medical conditions travel about 60 percent of what the average person travels. Non-drivers and persons in zero-vehicle households travel only one half as much as the average person.

The degree to which persons in each of these key markets travel less than the average person is similar between Florida and the U.S. for most of these markets. Non-drivers and persons in zerovehicle households are two exceptions. The degree to which persons from these two markets travel less than the average person is still greater in Florida than in the U.S. as a whole.

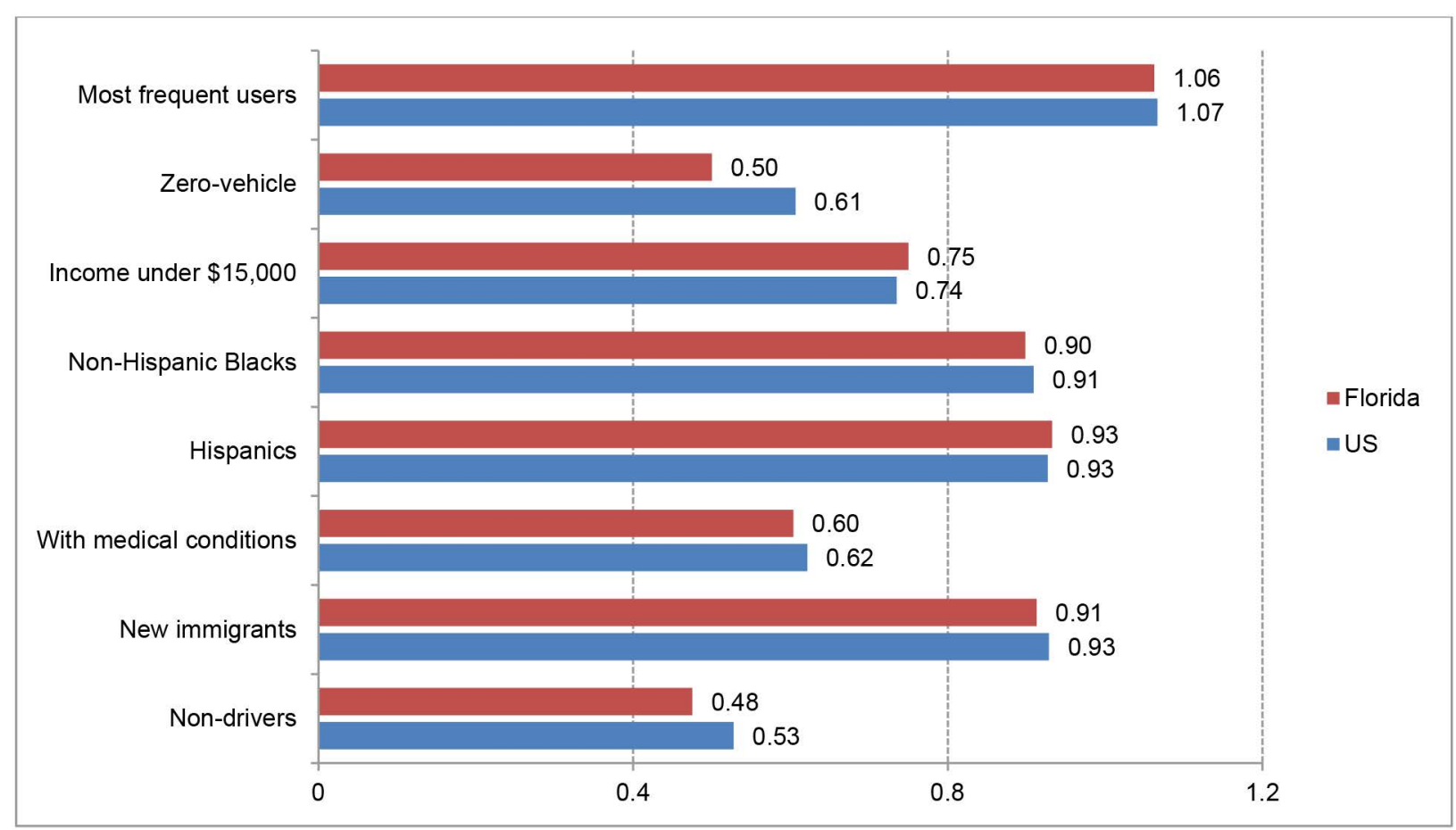

Figure 3.5. Relative General Mobility 


\section{ATTITUDES OF TRANSIT MARKETS}

This section assesses transit markets in terms of the attitudes of the transit trip makers. The data include what are considered to be the most important issue among a list of six issues and the seriousness of each of the six issues. There are three levels for the seriousness of an issue:

- A little issue (interpreted in this section as not a problem)

- A moderate issue (interpreted in this section as not a serious problem)

- A big issue (interpreted in this section as a serious problem)

Section 4.1 compares these attitudes for U.S. trip makers between transit and each of other modes. The purpose is to show whether and how transit trip makers view these issues differently from trip makers of other modes. Section 4.2 compares these attitudes of transit trip makers between Florida and the U.S. as a whole at the aggregate level without separating the transit markets based on various characteristics. The next eight sections then compare these attitudes of transit trip makers in the U.S. across the set of transit markets based on each given characteristic used in defining transit markets. There are eight characteristics:

- Driver status

- Immigration status

- Medical conditions

- Household income

- Vehicle availability

- Race and ethnicity

- Frequency of transit use

- Trip purpose

It is important to point out that the data on attitudes towards the seriousness of each issue may appear inconsistent with the data on attitudes towards what is the most important issue. The reader should keep in mind that the importance of an issue and its seriousness are necessarily the same.

\subsection{Modal Comparison}

This section compares attitudes of trip makers between transit and each of the other modes for the U.S. as whole. The purpose of this comparison is to provide a broader picture before assessing the attitudes of transit trip makers in detail. It is noted that many transit users also use other modes. As a result, the attitudes of these transit users appear not only among transit trip makers but also among trip makers of other modes that these transit users also used on the travel day.

Table 4.1 tabulates the results on attitudes of trip makers by mode. The first row shows the results identified as the most important transportation issue among the list of six pre-identified issues. The 
other six rows show the results on attitudes towards the seriousness of each of these issues. Within each row, results are presented for transit and four other major modes, including POV driving, POV riding, walking, and biking. The last column shows the results for all modes combined.

Table 4.1. Attitudes by Mode for the U.S.

\begin{tabular}{|c|c|c|c|c|c|c|c|}
\hline \multicolumn{2}{|c|}{ Issues and Attitudes } & Transit & $\begin{array}{l}\text { POV } \\
\text { Driver }\end{array}$ & $\begin{array}{c}\text { POV } \\
\text { Passenger }\end{array}$ & Walk & Bike & $\begin{array}{c}\text { All } \\
\text { Modes }\end{array}$ \\
\hline \multirow{7}{*}{$\begin{array}{l}\text { Most important } \\
\text { issue }\end{array}$} & Highway congestion & $7.3 \%$ & $16.2 \%$ & $13.2 \%$ & $12.7 \%$ & $12.6 \%$ & $15.1 \%$ \\
\hline & Access \& avallability of transit & $32.1 \%$ & $5.5 \%$ & $0.4 \%$ & $14.3 \%$ & $13.8 \%$ & $1.5 \%$ \\
\hline & Lack of walkways \& sidewalks & $4.2 \%$ & $2.9 \%$ & $3.1 \%$ & $6.1 \%$ & $11.9 \%$ & $3.4 \%$ \\
\hline & Price of travel & $32.2 \%$ & $38.7 \%$ & $37.2 \%$ & $35.3 \%$ & $28.5 \%$ & $37.7 \%$ \\
\hline & Aggressive \& distracted drivers & $8.4 \%$ & $18.5 \%$ & $17.5 \%$ & $15.6 \%$ & $18.2 \%$ & $17.7 \%$ \\
\hline & Safety concerns & $15.2 \%$ & $18.2 \%$ & $22.6 \%$ & $15.4 \%$ & $15.1 \%$ & $18.5 \%$ \\
\hline & All & $100.0 \%$ & $100.0 \%$ & $100.0 \%$ & $100.0 \%$ & $100.0 \%$ & $100.0 \%$ \\
\hline \multirow{4}{*}{$\begin{array}{l}\text { Highway } \\
\text { congestion }\end{array}$} & Not a problem & $7.4 \%$ & $10.3 \%$ & $8.7 \%$ & $11.6 \%$ & $10.2 \%$ & $10.3 \%$ \\
\hline & Not a serious problem & $42.6 \%$ & $43.1 \%$ & $42.4 \%$ & $39.2 \%$ & $62.4 \%$ & $43.0 \%$ \\
\hline & A serious problem & $50.0 \%$ & $46.6 \%$ & $49.0 \%$ & $49.2 \%$ & $27.4 \%$ & $46.7 \%$ \\
\hline & All & $100.0 \%$ & $100.0 \%$ & $100.0 \%$ & $100.0 \%$ & $100.0 \%$ & $100.0 \%$ \\
\hline \multirow{4}{*}{$\begin{array}{l}\text { Access to \& } \\
\text { availability of } \\
\text { transit }\end{array}$} & Not a problem & $13.9 \%$ & $12.1 \%$ & $12.6 \%$ & $14.8 \%$ & $9.8 \%$ & $13.1 \%$ \\
\hline & Not a serious problem & $20.9 \%$ & $35.4 \%$ & $32.4 \%$ & $24.7 \%$ & $29.7 \%$ & $31.7 \%$ \\
\hline & A serious problem & $65.2 \%$ & $52.5 \%$ & $55.0 \%$ & $60.5 \%$ & $60.4 \%$ & $55.2 \%$ \\
\hline & All & $100.0 \%$ & $100.0 \%$ & $100.0 \%$ & $100.0 \%$ & $100.0 \%$ & $100.0 \%$ \\
\hline \multirow{4}{*}{$\begin{array}{l}\text { Lack of } \\
\text { walkways \& } \\
\text { sidewalks }\end{array}$} & Not a problem & $12.9 \%$ & $10.6 \%$ & $13.4 \%$ & $18.4 \%$ & $3.5 \%$ & $12.5 \%$ \\
\hline & Not a serious problem & $31.0 \%$ & $43.7 \%$ & $48.5 \%$ & $40.8 \%$ & $46.6 \%$ & $42.8 \%$ \\
\hline & A serious problem & $56.1 \%$ & $45.7 \%$ & $38.1 \%$ & $40.8 \%$ & $49.9 \%$ & $44.7 \%$ \\
\hline & All & $100.0 \%$ & $100.0 \%$ & $100.0 \%$ & $100.0 \%$ & $100.0 \%$ & $100.0 \%$ \\
\hline \multirow{4}{*}{ Price of travel } & Not a problem & $5.2 \%$ & $6.0 \%$ & $6.0 \%$ & $7.7 \%$ & $4.8 \%$ & $6.3 \%$ \\
\hline & Not a serious problem & $32.9 \%$ & $33.2 \%$ & $34.2 \%$ & $34.6 \%$ & $46.3 \%$ & $33.5 \%$ \\
\hline & A serious problem & $61.8 \%$ & $60.8 \%$ & $59.9 \%$ & $57.7 \%$ & $48.8 \%$ & $60.3 \%$ \\
\hline & All & $100.0 \%$ & $100.0 \%$ & $100.0 \%$ & $100.0 \%$ & $100.0 \%$ & $100.0 \%$ \\
\hline \multirow{4}{*}{$\begin{array}{l}\text { Aggressive \& } \\
\text { distracted } \\
\text { drivers }\end{array}$} & Not a problem & $4.7 \%$ & $9.3 \%$ & $8.0 \%$ & $10.7 \%$ & $6.1 \%$ & $9.3 \%$ \\
\hline & Not a serious problem & $39.8 \%$ & $42.1 \%$ & $43.2 \%$ & $38.7 \%$ & $39.5 \%$ & $41.8 \%$ \\
\hline & A serious problem & $55.4 \%$ & $48.6 \%$ & $48.8 \%$ & $50.6 \%$ & $54.4 \%$ & $49.0 \%$ \\
\hline & All & $100.0 \%$ & $100.0 \%$ & $100.0 \%$ & $100.0 \%$ & $100.0 \%$ & $100.0 \%$ \\
\hline \multirow{4}{*}{$\begin{array}{l}\text { Safety } \\
\text { concerns }\end{array}$} & Not a problem & $14.2 \%$ & $15.0 \%$ & $13.9 \%$ & $16.5 \%$ & $11.3 \%$ & $14.7 \%$ \\
\hline & Not a serious problem & $32.2 \%$ & $42.9 \%$ & $44.4 \%$ & $37.9 \%$ & $43.3 \%$ & $42.3 \%$ \\
\hline & A serious problem & $53.6 \%$ & $42.1 \%$ & $41.7 \%$ & $45.6 \%$ & $45.3 \%$ & $43.0 \%$ \\
\hline & All & $100.0 \%$ & $100.0 \%$ & $100.0 \%$ & $100.0 \%$ & $100.0 \%$ & $100.0 \%$ \\
\hline
\end{tabular}

\subsubsection{Most Important Issue}

For trip makers of all modes, the most significant issue is the price of travel, with 37.7 percent choosing it as the most important issue. The least significant issues are access to and availability of transit and lacking walkways and sidewalks. Only 7.5 percent chose access to and availability of transit and only 3.4 percent chose lacking walkways and sidewalks. The other three issues fall in the middle, including highway congestion, aggressive and distracted drivers, and safety concerns at 15.1 percent, 17.7 percent, and 18.5 percent, respectively.

With a few exceptions, the most important issues do not vary much across the modes. An exception relates to the issue of access to and availability of transit. It is more significant to trip 
makers of transit, walking, and biking than those of other modes and is the most important issue to almost one-third of transit trip makers and about 14.0 percent of trip makers via walking and biking.

\subsubsection{Seriousness of Issues}

For trip makers of all modes, 60.3 percent consider the price of travel as a serious problem and 55.2 percent consider access to and availability of transit as a serious one. Less than one-half consider each of the other issues to be a serious problem. A larger proportion of transit trip makers consider these issues to be serious than do trip makers of other modes. In addition, each issue is seen as a serious problem by at least 50 percent of transit trip makers.

\subsection{Comparison of Florida and U.S.}

Table 4.1 presents results on these attitudes for Florida and the U.S.

Table 4.2. Attitudes of Transit Users for Florida and the U.S.

\begin{tabular}{|c|c|c|c|}
\hline \multicolumn{2}{|c|}{ Issues and Attributes } & Florida & U.S. \\
\hline \multirow{7}{*}{$\begin{array}{l}\text { Most important } \\
\text { issue }\end{array}$} & Highway congestion & $13.4 \%$ & $7.3 \%$ \\
\hline & Access to $\&$ availability of transit & $35.9 \%$ & $32.7 \%$ \\
\hline & Lack of walkways \& sidewalks & $8.5 \%$ & $4.2 \%$ \\
\hline & Price of travel & $17.5 \%$ & $32.2 \%$ \\
\hline & Aggressive \& distracted drivers & $8.9 \%$ & $8.4 \%$ \\
\hline & Safety concerns & $15.8 \%$ & $15.2 \%$ \\
\hline & All & $100.0 \%$ & $100.0 \%$ \\
\hline \multirow{4}{*}{ Highway congestion } & Not a problem & $5.3 \%$ & $7.4 \%$ \\
\hline & Not a serious problem & $76.7 \%$ & $42.6 \%$ \\
\hline & A serious problem & $18.0 \%$ & $50.0 \%$ \\
\hline & All & $100.0 \%$ & $100.0 \%$ \\
\hline \multirow{4}{*}{$\begin{array}{l}\text { Access to \& } \\
\text { availability of transit }\end{array}$} & Not a problem & $23.8 \%$ & $13.9 \%$ \\
\hline & Not a serious problem & $23.9 \%$ & $20.9 \%$ \\
\hline & A serious problem & $52.3 \%$ & $65.2 \%$ \\
\hline & All & $100.0 \%$ & $100.0 \%$ \\
\hline \multirow{4}{*}{$\begin{array}{l}\text { Lack of walkways \& } \\
\text { sidewalks }\end{array}$} & Not a problem & $17.2 \%$ & $12.9 \%$ \\
\hline & Not a serious problem & $21.5 \%$ & $31.0 \%$ \\
\hline & A serious problem & $61.3 \%$ & $56.1 \%$ \\
\hline & All & $100.0 \%$ & $100.0 \%$ \\
\hline \multirow{4}{*}{ Price of travel } & Not a problem & $10.8 \%$ & $5.2 \%$ \\
\hline & Not a serious problem & $43.8 \%$ & $32.9 \%$ \\
\hline & A serious problem & $45.4 \%$ & $61.8 \%$ \\
\hline & All & $100.0 \%$ & $100.0 \%$ \\
\hline \multirow{4}{*}{$\begin{array}{l}\text { Aggressive \& } \\
\text { distracted drivers }\end{array}$} & Not a problem & $21.7 \%$ & $4.7 \%$ \\
\hline & Not a serious problem & $9.6 \%$ & $39.8 \%$ \\
\hline & A serious problem & $68.7 \%$ & $55.4 \%$ \\
\hline & All & $100.0 \%$ & $100.0 \%$ \\
\hline \multirow{4}{*}{ Safety concerns } & Not a problem & $17.7 \%$ & $14.2 \%$ \\
\hline & Not a serious problem & $36.5 \%$ & $32.2 \%$ \\
\hline & A serious problem & $45.8 \%$ & $53.6 \%$ \\
\hline & All & $100.0 \%$ & $100.0 \%$ \\
\hline
\end{tabular}




\subsubsection{Most Important Issue}

By far the most important issues to transit trip makers in the U.S. are access to and availability of transit and the price of travel. One-third (32.7\%) felt that access to and availability of transit was the most important issue. Another one-third felt that the price of travel was the most important issue. More transit trip makers see safety-related issues as the most important than the issues of high congestion and lacking pedestrian facilities. Safety concerns were considered to be the most important by $15.2 \%$, vs. 8.4 for the issue of aggressive and distracted drivers, 7.3 percent for highway congestion, and 4.2 percent for lack of pedestrian facilities.

The most important issue to transit trip makers in Florida is access to and availability of transit. More than one-third felt that this was the most important issue (35.9\%), which is higher than in the U.S. Another 13.4-17.5 percent said that their most important issue was the price of travel, safety concerns, or highway congestion. Less than 10 percent felt that the issues of aggressive and distracted drivers and lacking walkways and sidewalks were most important to them.

\subsubsection{Seriousness of Issues}

Except for the issue of highway congestion, more transit users in Florida consider each of the other issues as not being a problem than in the U.S. as a whole. At the same time, more transit trip makers see lacking walkways and sidewalks and aggressive and distracted drivers as serious problems in Florida than in the U.S. The issue of aggressive and distracted drivers is seen as a serious problem by 68.7 percent of transit trip makers in Florida, compared to 55.4 percent in the U.S. The issue of lacking walkways and sidewalks is seen as a serious problem by 61.3 percent of transit trip makers in Florida, compared to 56.1 percent in the U.S.

On the other hand, fewer transit trip makers in Florida consider each of the other issues being serious than in the U.S. as a whole. The difference in the percent of transit trip makers who view an issue being serious between Florida and the U.S. is 32 percent for highway congestion, 16.4 for the price of travel, 13.3 percent for aggressive and distracted drivers, 12.9 for access to and availability of transit, and 7.8 for safety concerns.

\subsection{Driver Status}

Table 4.3 presents results on attitudes for transit markets based on driver status for the U.S. as a whole.

\subsubsection{Most Important Issue}

The most important issues to non-drivers of transit trip makers also are access to and availability of transit and the price of travel. However, more non-drivers consider the price of travel to be the most important than drivers. Specifically, 42.9 percent of non-drivers consider the price of travel to be the most important issue, compared to 30.8 percent for drivers. On the other hand, fewer nondrivers consider access to and availability of transit to be the most important issue than drivers. 


\subsubsection{Seriousness of Issues}

Lacking walkways and sidewalks is a problem to the vast majority of non-drivers (96.8\%) vs. drivers $(43.6 \%)$. On the other hand, significantly fewer non-drivers consider highway congestion and safety concerns to be serious than drivers. Only 26.5 percent of non-drivers see highway congestion as a serious problem vs. 51.9 percent of drivers. Similarly, 41.6 percent of non-drivers believe that safety concerns are a serious problem, compared with 55.0 percent of drivers.

Table 4.3. Attitudes of U.S. Transit Markets by Driver Status

\begin{tabular}{|c|c|c|c|c|}
\hline \multirow{2}{*}{\multicolumn{2}{|c|}{ Issues and Attributes }} & \multicolumn{2}{|c|}{ Driver Status } & \multirow[b]{2}{*}{ Total } \\
\hline & & \multirow{2}{*}{$\begin{array}{r}\text { Driver } \\
7.7 \%\end{array}$} & \multirow{2}{*}{$\begin{array}{r}\begin{array}{c}\text { Non- } \\
\text { Driver }\end{array} \\
4.7 \%\end{array}$} & \\
\hline \multirow{7}{*}{$\begin{array}{l}\text { Most important } \\
\text { issue }\end{array}$} & Highway congestion & & & $7.3 \%$ \\
\hline & Access \& availability of transit & $33.6 \%$ & $26.4 \%$ & $32.7 \%$ \\
\hline & Lack of walkways \& sidewalks & $3.6 \%$ & $8.3 \%$ & $4.2 \%$ \\
\hline & Price of travel & $30.8 \%$ & $42.9 \%$ & $32.2 \%$ \\
\hline & Aggressive \& distracted drivers & $8.8 \%$ & $5.0 \%$ & $8.4 \%$ \\
\hline & Safety concerns & $15.5 \%$ & $12.7 \%$ & $15.2 \%$ \\
\hline & All & $100.0 \%$ & $100.0 \%$ & $100.0 \%$ \\
\hline \multirow{4}{*}{$\begin{array}{l}\text { Highway } \\
\text { congestion }\end{array}$} & Not a problem & $6.6 \%$ & $17.6 \%$ & $7.4 \%$ \\
\hline & Not a serious problem & $41.5 \%$ & $56.0 \%$ & $42.6 \%$ \\
\hline & A serious problem & $51.9 \%$ & $26.5 \%$ & $50.0 \%$ \\
\hline & All & $100.0 \%$ & $100.0 \%$ & $100.0 \%$ \\
\hline \multirow{4}{*}{$\begin{array}{l}\text { Access to \& } \\
\text { availability of } \\
\text { transit }\end{array}$} & Not a problem & $13.3 \%$ & $19.5 \%$ & $13.9 \%$ \\
\hline & Not a serious problem & $21.1 \%$ & $18.6 \%$ & $20.9 \%$ \\
\hline & A serious problem & $65.6 \%$ & $61.8 \%$ & $65.2 \%$ \\
\hline & All & $100.0 \%$ & $100.0 \%$ & $100.0 \%$ \\
\hline \multirow{4}{*}{$\begin{array}{l}\text { Lack of walkways } \\
\& \text { sidewalks }\end{array}$} & Not a problem & $16.0 \%$ & $2.7 \%$ & $12.9 \%$ \\
\hline & Not a serious problem & $40.4 \%$ & $0.5 \%$ & $31.0 \%$ \\
\hline & A serious problem & $43.6 \%$ & $96.8 \%$ & $56.1 \%$ \\
\hline & All & $100.0 \%$ & $100.0 \%$ & $100.0 \%$ \\
\hline \multirow{4}{*}{ Price of travel } & Not a problem & $3.9 \%$ & $12.6 \%$ & $5.2 \%$ \\
\hline & Not a serious problem & $34.4 \%$ & $25.3 \%$ & $32.9 \%$ \\
\hline & A serious problem & $61.8 \%$ & $62.1 \%$ & $61.8 \%$ \\
\hline & All & $100.0 \%$ & $100.0 \%$ & $100.0 \%$ \\
\hline \multirow{4}{*}{$\begin{array}{l}\text { Aggressive \& } \\
\text { distracted drivers }\end{array}$} & Not a problem & $4.4 \%$ & $8.8 \%$ & $4.7 \%$ \\
\hline & Not a serious problem & $40.2 \%$ & $35.2 \%$ & $39.8 \%$ \\
\hline & A serious problem & $55.4 \%$ & $56.0 \%$ & $55.4 \%$ \\
\hline & All & $100.0 \%$ & $100.0 \%$ & $100.0 \%$ \\
\hline \multirow{4}{*}{ Safety concerns } & Not a problem & $12.7 \%$ & $27.6 \%$ & $14.2 \%$ \\
\hline & Not a serious problem & $32.3 \%$ & $30.9 \%$ & $32.2 \%$ \\
\hline & A serious problem & $55.0 \%$ & $41.6 \%$ & $53.6 \%$ \\
\hline & All & $100.0 \%$ & $100.0 \%$ & $100.0 \%$ \\
\hline
\end{tabular}

\subsection{Immigration Status}

Table 4.4 presents results on attitudes for transit markets based on immigration status for the U.S. as a whole. 


\subsubsection{Most Important Issue}

While the most important issues are largely similar between older immigrants and non-immigrants, new immigrants appear to have different opinions. Far fewer new immigrants think that the price of travel is the most important issue than older immigrants or non-immigrants $(21.7 \%$ vs. $32.4-33.9 \%)$. In addition, far more new immigrants view highway congestion and lack of walkways and sidewalks as the most important issue than other markets. For example, 15.5 percent of new immigrants see highway congestion as the most important issue, but only 6.0 percent of non-immigrants see it that way.

Table 4.4. Attitudes of U.S. Transit Markets by Immigration Status

\begin{tabular}{|c|c|c|c|c|c|}
\hline \multirow{2}{*}{\multicolumn{2}{|c|}{ Issues and Attributes }} & \multicolumn{3}{|c|}{ Immigration Status } & \multirow[b]{2}{*}{ Total } \\
\hline & & \multirow{2}{*}{$\begin{array}{c}\begin{array}{c}\text { New } \\
\text { Immigrant }\end{array} \\
15.5 \%\end{array}$} & \multirow{2}{*}{$\begin{array}{c}\begin{array}{c}\text { Older } \\
\text { Immigrant }\end{array} \\
8.5 \%\end{array}$} & \multirow{2}{*}{$\begin{array}{c}\begin{array}{c}\text { Non } \\
\text { Immigrant }\end{array} \\
6.0 \%\end{array}$} & \\
\hline \multirow{7}{*}{$\begin{array}{l}\text { Most important } \\
\text { issue }\end{array}$} & Highway congestion & & & & $7.4 \%$ \\
\hline & Access \& availability of transit & $29.4 \%$ & $29.4 \%$ & $34.6 \%$ & $32.9 \%$ \\
\hline & Lack of walkways \& sidewalks & $10.7 \%$ & $0.6 \%$ & $4.7 \%$ & $4.2 \%$ \\
\hline & Price of travel & $21.7 \%$ & $33.9 \%$ & $32.4 \%$ & $31.9 \%$ \\
\hline & Aggressive \& distracted drivers & $5.2 \%$ & $8.5 \%$ & $8.7 \%$ & $8.3 \%$ \\
\hline & Safety concerns & $17.5 \%$ & $19.1 \%$ & $13.7 \%$ & $15.3 \%$ \\
\hline & All & $100.0 \%$ & $100.0 \%$ & $100.0 \%$ & $100.0 \%$ \\
\hline \multirow{4}{*}{$\begin{array}{l}\text { Highway } \\
\text { congestion }\end{array}$} & Not a problem & $11.6 \%$ & $10.4 \%$ & $4.8 \%$ & $7.5 \%$ \\
\hline & Not a serious problem & $58.5 \%$ & $50.2 \%$ & $34.2 \%$ & $42.8 \%$ \\
\hline & A serious problem & $29.9 \%$ & $39.4 \%$ & $61.0 \%$ & $49.7 \%$ \\
\hline & All & $100.0 \%$ & $100.0 \%$ & $100.0 \%$ & $100.0 \%$ \\
\hline \multirow{4}{*}{$\begin{array}{l}\text { Access to \& } \\
\text { availability of } \\
\text { transit }\end{array}$} & Not a problem & $18.5 \%$ & $14.6 \%$ & $12.9 \%$ & $13.7 \%$ \\
\hline & Not a serious problem & $35.5 \%$ & $26.4 \%$ & $17.8 \%$ & $20.9 \%$ \\
\hline & A serious problem & $46.1 \%$ & $59.0 \%$ & $69.2 \%$ & $65.4 \%$ \\
\hline & All & $100.0 \%$ & $100.0 \%$ & $100.0 \%$ & $100.0 \%$ \\
\hline \multirow{4}{*}{$\begin{array}{l}\text { Lack of walkways } \\
\& \text { sidewalks }\end{array}$} & Not a problem & $0.2 \%$ & $45.7 \%$ & $15.2 \%$ & $12.9 \%$ \\
\hline & Not a serious problem & $11.0 \%$ & $19.4 \%$ & $37.2 \%$ & $31.0 \%$ \\
\hline & A serious problem & $88.8 \%$ & $34.9 \%$ & $47.6 \%$ & $56.1 \%$ \\
\hline & All & $100.0 \%$ & $100.0 \%$ & $100.0 \%$ & $100.0 \%$ \\
\hline \multirow{4}{*}{ Price of travel } & Not a problem & $11.9 \%$ & $6.9 \%$ & $4.3 \%$ & $5.4 \%$ \\
\hline & Not a serious problem & $41.3 \%$ & $33.5 \%$ & $32.8 \%$ & $33.5 \%$ \\
\hline & A serious problem & $46.7 \%$ & $59.5 \%$ & $62.9 \%$ & $61.1 \%$ \\
\hline & All & $100.0 \%$ & $100.0 \%$ & $100.0 \%$ & $100.0 \%$ \\
\hline \multirow{4}{*}{$\begin{array}{l}\text { Aggressive \& } \\
\text { distracted drivers }\end{array}$} & Not a problem & $10.8 \%$ & $7.8 \%$ & $3.4 \%$ & $4.8 \%$ \\
\hline & Not a serious problem & $48.4 \%$ & $22.1 \%$ & $44.7 \%$ & $39.7 \%$ \\
\hline & A serious problem & $40.7 \%$ & $70.1 \%$ & $51.9 \%$ & $55.5 \%$ \\
\hline & All & $100.0 \%$ & $100.0 \%$ & $100.0 \%$ & $100.0 \%$ \\
\hline \multirow{4}{*}{ Safety concerns } & Not a problem & $28.5 \%$ & $8.2 \%$ & $15.0 \%$ & $14.3 \%$ \\
\hline & Not a serious problem & $33.2 \%$ & $30.7 \%$ & $32.4 \%$ & $32.0 \%$ \\
\hline & A serious problem & $38.3 \%$ & $61.1 \%$ & $52.6 \%$ & $53.7 \%$ \\
\hline & All & $100.0 \%$ & $100.0 \%$ & $100.0 \%$ & $100.0 \%$ \\
\hline
\end{tabular}

\subsubsection{Seriousness of Issues}

The vast majority of new immigrants (88.8\%) consider lacking walkways and sidewalks to be serious vs. 47.6 percent of non-immigrants. For all other issues, fewer new immigrants view them as a serious problem than either older immigrants or non-immigrants. Highway congestion is seen 
as a serious problem by 29.9 percent of new immigrants, 39.4 percent of older immigrants, and 61.0 percent of non-immigrants. Access to and availability of transit is considered serious to 46.1 percent of new immigrants compared to 59.0 percent of older immigrants and 69.2 percent of nonimmigrants.

\subsection{Medical Conditions}

Table 4.5 presents results on attitudes for transit markets based on medical conditions for the U.S.

Table 4.5. Attitudes of U.S. Transit Markets by Medical Conditions

\begin{tabular}{|c|c|c|c|c|}
\hline \multicolumn{2}{|c|}{ Issues and Attributes } & \multicolumn{2}{|c|}{$\begin{array}{c}\text { Existence of Medical } \\
\text { Conditions }\end{array}$} & \multirow{3}{*}{$\begin{array}{r}\text { Total } \\
7.3 \%\end{array}$} \\
\hline Issue & and Attrioutes & \multirow{2}{*}{$\begin{array}{r}\begin{array}{c}\text { Having Medical } \\
\text { Conditions }\end{array} \\
6.4 \%\end{array}$} & \multirow{2}{*}{$\begin{array}{r}\begin{array}{l}\text { No Medical } \\
\text { Conditions }\end{array} \\
7.4 \%\end{array}$} & \\
\hline \multirow{7}{*}{ Most important issue } & Highway congestion & & & \\
\hline & Access $\&$ availability of transit & $32.1 \%$ & $32.8 \%$ & $32.7 \%$ \\
\hline & Lack of walkways \& sidewalks & $4.9 \%$ & $4.1 \%$ & $4.2 \%$ \\
\hline & Price of travel & $23.7 \%$ & $33.4 \%$ & $32.3 \%$ \\
\hline & Aggressive \& distracted drivers & $8.9 \%$ & $8.3 \%$ & $8.4 \%$ \\
\hline & Safety concerns & $24.1 \%$ & $14.0 \%$ & $15.1 \%$ \\
\hline & All & $100.0 \%$ & $100.0 \%$ & $100.0 \%$ \\
\hline \multirow{4}{*}{ Highway congestion } & Not a problem & $2.5 \%$ & $8.0 \%$ & $7.4 \%$ \\
\hline & Not a serious problem & $55.3 \%$ & $41.2 \%$ & $42.6 \%$ \\
\hline & A serious problem & $42.2 \%$ & $50.9 \%$ & $50.0 \%$ \\
\hline & All & $100.0 \%$ & $100.0 \%$ & $100.0 \%$ \\
\hline \multirow{4}{*}{$\begin{array}{l}\text { Access to \& availability } \\
\text { of transit }\end{array}$} & Not a problem & $13.0 \%$ & $14.0 \%$ & $13.9 \%$ \\
\hline & Not a serious problem & $32.0 \%$ & $19.5 \%$ & $20.9 \%$ \\
\hline & A serious problem & $55.0 \%$ & $66.5 \%$ & $65.2 \%$ \\
\hline & All & $100.0 \%$ & $100.0 \%$ & $100.0 \%$ \\
\hline \multirow{4}{*}{$\begin{array}{l}\text { Lack of walkways \& } \\
\text { sidewalks }\end{array}$} & Not a problem & $9.6 \%$ & $13.4 \%$ & $12.9 \%$ \\
\hline & Not a serious problem & $14.7 \%$ & $33.5 \%$ & $31.0 \%$ \\
\hline & A serious problem & $75.7 \%$ & $53.1 \%$ & $56.1 \%$ \\
\hline & All & $100.0 \%$ & $100.0 \%$ & $100.0 \%$ \\
\hline \multirow{4}{*}{ Price of travel } & Not a problem & $1.4 \%$ & $5.6 \%$ & $5.2 \%$ \\
\hline & Not a serious problem & $6.5 \%$ & $35.3 \%$ & $32.9 \%$ \\
\hline & A serious problem & $92.1 \%$ & $59.1 \%$ & $61.8 \%$ \\
\hline & All & $100.0 \%$ & $100.0 \%$ & $100.0 \%$ \\
\hline \multirow{4}{*}{$\begin{array}{l}\text { Aggressive \& distracted } \\
\text { drivers }\end{array}$} & Not a problem & $4.6 \%$ & $4.9 \%$ & $4.8 \%$ \\
\hline & Not a serious problem & $65.0 \%$ & $36.0 \%$ & $39.7 \%$ \\
\hline & A serious problem & $30.4 \%$ & $59.1 \%$ & $55.5 \%$ \\
\hline & All & $100.0 \%$ & $100.0 \%$ & $100.0 \%$ \\
\hline \multirow{4}{*}{ Safety concerns } & Not a problem & $13.5 \%$ & $14.4 \%$ & $14.2 \%$ \\
\hline & Not a serious problem & $22.2 \%$ & $34.5 \%$ & $32.3 \%$ \\
\hline & A serious problem & $64.3 \%$ & $51.2 \%$ & $53.5 \%$ \\
\hline & All & $100.0 \%$ & $100.0 \%$ & $100.0 \%$ \\
\hline
\end{tabular}

\subsubsection{Most Important Issue}

Access to and availability of transit is the most important issue to as many persons with medical conditions as those without medical conditions. However, far fewer persons with medical conditions see the price of travel as the most important than persons without conditions. Specifically, 23.7 percent of persons with conditions see the price of travel as the most important issue, compared to 
33.4 percent for persons without conditions. On the other hand, safety concerns appear to be far more important to persons with medical conditions than to persons without conditions. Some 24.1 percent of persons with medical conditions consider safety concerns the most important issue, compared to 14.0 percent for persons without conditions.

\subsubsection{Seriousness of Issues}

More persons with medical conditions consider lacking walkways and sidewalks, the price of travel, and safety concerns to be serious problems than persons without conditions. The most significant difference is in the price of travel: 92.1 percent of persons with medical conditions think that the price of travel is a serious problem, compared to 59.1 percent of persons without conditions. On the other hand, fewer persons with medical conditions view the other issues to be serious, including highway congestion, access to and availability of transit, and aggressive and distracted drivers.

\subsection{Household Income}

Table 4.6 presents results on attitudes for transit markets based on household income for the U.S.

\subsubsection{Most Important Issue}

The three markets with household income under $\$ 100,000$ appear to be similar in their views on what they consider to be the most important issue. The highest income market, however, seem to think quite differently. While they are still similar with the other income-based markets about lacking walkways and sidewalks and aggressive and distracted drivers, they are far more likely to see highway congestion and access to and availability of transit to be the most important issue. On the other hand, they are significantly less likely to consider the price of travel and safety concerns to be the most important issue.

\subsubsection{Seriousness of Issues}

The seriousness of several of the issues appears to change with income in a systematic way. These issues include access to and availability of transit, the price of travel, and safety concerns. Consider access to and availability of transit first: The share of transit trip makers within each income-based market who consider it to be the most important issue is 49.6 percent for the lowincome market, 62.8 percent for the middle low-income market, 73.0 percent for the middle highincome market, and 76.8 percent for the high-income market. On safety concerns, the share decreases with income: 65.7 percent for the low-income market, 59.8 percent for the middle lowincome market, 25.2 percent for the middle high-income market, and 13.3 percent for the highincome market. 
Table 4.6. Attitudes of U.S. Transit Markets by Household Income

\begin{tabular}{|c|c|c|c|c|c|c|}
\hline \multirow{2}{*}{\multicolumn{2}{|c|}{ Issues and Attributes }} & \multicolumn{4}{|c|}{ Annual Household Income } & \multirow{2}{*}{ Total } \\
\hline & & $\begin{array}{l}\text { Under } \\
\$ 15,000\end{array}$ & $\begin{array}{l}\$ 15,000- \\
\$ 49,999\end{array}$ & $\begin{array}{l}\$ 50,000- \\
\$ 99,999\end{array}$ & $\$ 100,000+$ & \\
\hline \multirow{7}{*}{$\begin{array}{l}\text { Most important } \\
\text { issue }\end{array}$} & Highway congestion & $6.3 \%$ & $5.4 \%$ & $7.7 \%$ & $14.5 \%$ & $7.3 \%$ \\
\hline & Access \& availability of transit & $26.3 \%$ & $31.1 \%$ & $32.7 \%$ & $48.4 \%$ & $32.4 \%$ \\
\hline & Lack of walkways \& sidewalks & $5.8 \%$ & $4.1 \%$ & $2.3 \%$ & $4.2 \%$ & $4.3 \%$ \\
\hline & Price of travel & $32.5 \%$ & $38.1 \%$ & $32.5 \%$ & $19.9 \%$ & $33.0 \%$ \\
\hline & Aggressive \& distracted drivers & $9.5 \%$ & $6.4 \%$ & $12.1 \%$ & $5.2 \%$ & $8.1 \%$ \\
\hline & Safety concerns & $19.6 \%$ & $15.0 \%$ & $12.6 \%$ & $7.7 \%$ & $14.8 \%$ \\
\hline & All & $100.0 \%$ & $100.0 \%$ & $100.0 \%$ & $100.0 \%$ & $100.0 \%$ \\
\hline \multirow{4}{*}{$\begin{array}{l}\text { Highway } \\
\text { congestion }\end{array}$} & Not a problem & $16.7 \%$ & $4.0 \%$ & $6.9 \%$ & $3.4 \%$ & $7.5 \%$ \\
\hline & Not a serious problem & $48.2 \%$ & $51.0 \%$ & $28.3 \%$ & $38.9 \%$ & $42.8 \%$ \\
\hline & A serious problem & $35.1 \%$ & $45.0 \%$ & $64.8 \%$ & $57.7 \%$ & $49.8 \%$ \\
\hline & All & $100.0 \%$ & $100.0 \%$ & $100.0 \%$ & $100.0 \%$ & $100.0 \%$ \\
\hline \multirow{4}{*}{$\begin{array}{l}\text { Access to \& } \\
\text { availability of } \\
\text { transit }\end{array}$} & Not a problem & $18.7 \%$ & $16.8 \%$ & $9.4 \%$ & $6.9 \%$ & $13.8 \%$ \\
\hline & Not a serious problem & $31.7 \%$ & $20.4 \%$ & $17.6 \%$ & $16.3 \%$ & $21.6 \%$ \\
\hline & A serious problem & $49.6 \%$ & $62.8 \%$ & $73.0 \%$ & $76.8 \%$ & $64.5 \%$ \\
\hline & All & $100.0 \%$ & $100.0 \%$ & $100.0 \%$ & $100.0 \%$ & $100.0 \%$ \\
\hline \multirow{4}{*}{$\begin{array}{l}\text { Lack of } \\
\text { walkways \& } \\
\text { sidewalks }\end{array}$} & Not a problem & $8.5 \%$ & $7.8 \%$ & $12.1 \%$ & $41.0 \%$ & $13.1 \%$ \\
\hline & Not a serious problem & $46.2 \%$ & $15.5 \%$ & $76.3 \%$ & -- & $31.0 \%$ \\
\hline & A serious problem & $45.2 \%$ & $76.8 \%$ & $11.6 \%$ & $59.0 \%$ & $56.0 \%$ \\
\hline & All & $100.0 \%$ & $100.0 \%$ & $100.0 \%$ & $100.0 \%$ & $100.0 \%$ \\
\hline \multirow{4}{*}{ Price of travel } & Not a problem & $10.1 \%$ & $2.5 \%$ & $1.4 \%$ & $11.1 \%$ & $5.2 \%$ \\
\hline & Not a serious problem & $16.4 \%$ & $34.3 \%$ & $51.1 \%$ & $44.9 \%$ & $33.1 \%$ \\
\hline & A serious problem & $73.5 \%$ & $63.2 \%$ & $47.5 \%$ & $44.0 \%$ & $61.7 \%$ \\
\hline & All & $100.0 \%$ & $100.0 \%$ & $100.0 \%$ & $100.0 \%$ & $100.0 \%$ \\
\hline \multirow{4}{*}{$\begin{array}{l}\text { Aggressive \& } \\
\text { distracted } \\
\text { drivers }\end{array}$} & Not a problem & $3.5 \%$ & $5.7 \%$ & $0.5 \%$ & $21.4 \%$ & $5.0 \%$ \\
\hline & Not a serious problem & $60.2 \%$ & $30.3 \%$ & $34.8 \%$ & $41.3 \%$ & $42.5 \%$ \\
\hline & A serious problem & $36.3 \%$ & $64.0 \%$ & $64.7 \%$ & $37.4 \%$ & $52.5 \%$ \\
\hline & All & $100.0 \%$ & $100.0 \%$ & $100.0 \%$ & $100.0 \%$ & $100.0 \%$ \\
\hline \multirow{4}{*}{$\begin{array}{l}\text { Safety } \\
\text { concerns }\end{array}$} & Not a problem & $16.2 \%$ & $11.4 \%$ & $7.3 \%$ & $28.6 \%$ & $13.8 \%$ \\
\hline & Not a serious problem & $18.1 \%$ & $28.9 \%$ & $67.6 \%$ & $58.1 \%$ & $32.8 \%$ \\
\hline & A serious problem & $65.7 \%$ & $59.8 \%$ & $25.2 \%$ & $13.3 \%$ & $53.4 \%$ \\
\hline & All & $100.0 \%$ & $100.0 \%$ & $100.0 \%$ & $100.0 \%$ & $100.0 \%$ \\
\hline
\end{tabular}

\subsection{Vehicle Availability}

Table 4.7 presents results on attitudes for transit markets based on vehicle availability for the U.S. as a whole.

\subsubsection{Most Important Issue}

The markets with lower availability of vehicles appear similar in their views of the most important issue. The market with adequate vehicles differs somewhat to these two markets. Specifically, highway congestion and aggressive and distracted drivers are the most important issue for a larger portion of the market with adequate vehicles than the other two markets. 


\subsubsection{Seriousness of Issues}

Considerably more transit trip makers in zero-vehicle households see both safety issues as a serious problem than transit trip makers with vehicles. For example, the issue of aggressive and distracted drivers is seen as serious by 67.7 percent of transit trip makers without vehicles, compared with 45.9 percent of those with inadequate vehicles.

Both issues of highway congestion and access to and availability of transit are considered to be a serious problem by far more transit trip makers with adequate vehicles than transit trip makers with lower availability of vehicles.

Table 4.7. Attitudes of U.S. Transit Markets by Vehicle Availability

\begin{tabular}{|c|c|c|c|c|c|}
\hline \multirow{2}{*}{\multicolumn{2}{|c|}{ Issues and Attributes }} & \multicolumn{3}{|c|}{$\begin{array}{c}\text { Vehicles Available Relative to } \\
\text { Workers }\end{array}$} & \multirow[b]{2}{*}{ Total } \\
\hline & & \multirow[t]{2}{*}{$\begin{array}{c}\begin{array}{c}\text { Zero } \\
\text { Vehicle }\end{array} \\
270 /\end{array}$} & $\begin{array}{c}\text { Vehicles } \\
< \\
\text { Workers }\end{array}$ & $\begin{array}{l}\text { Vehicles } \\
>= \\
\text { Workers }\end{array}$ & \\
\hline \multirow{7}{*}{$\begin{array}{l}\text { Most important } \\
\text { issue }\end{array}$} & Highway congestion & & $5.7 \%$ & $13.3 \%$ & $7.3 \%$ \\
\hline & Access \& availability of transit & $35.7 \%$ & $37.1 \%$ & $26.4 \%$ & $32.7 \%$ \\
\hline & Lack of walkways \& sidewalks & $5.2 \%$ & $4.2 \%$ & $2.6 \%$ & $4.2 \%$ \\
\hline & Price of travel & $31.9 \%$ & $30.0 \%$ & $33.7 \%$ & $32.2 \%$ \\
\hline & Aggressive \& distracted drivers & $6.9 \%$ & $6.6 \%$ & $11.4 \%$ & $8.4 \%$ \\
\hline & Safety concerns & $16.6 \%$ & $16.4 \%$ & $12.5 \%$ & $15.2 \%$ \\
\hline & All & $100.0 \%$ & $100.0 \%$ & $100.0 \%$ & $100.0 \%$ \\
\hline \multirow{4}{*}{$\begin{array}{l}\text { Highway } \\
\text { congestion }\end{array}$} & Not a problem & $10.7 \%$ & $12.1 \%$ & $5.2 \%$ & $7.4 \%$ \\
\hline & Not a serious problem & $48.2 \%$ & $56.0 \%$ & $37.8 \%$ & $42.6 \%$ \\
\hline & A serious problem & $41.1 \%$ & $31.9 \%$ & $57.0 \%$ & $50.0 \%$ \\
\hline & All & $100.0 \%$ & $100.0 \%$ & $100.0 \%$ & $100.0 \%$ \\
\hline \multirow{4}{*}{$\begin{array}{l}\text { Access to \& } \\
\text { availability of transit }\end{array}$} & Not a problem & $16.9 \%$ & $12.3 \%$ & $8.9 \%$ & $13.9 \%$ \\
\hline & Not a serious problem & $21.6 \%$ & $23.4 \%$ & $17.9 \%$ & $20.9 \%$ \\
\hline & A serious problem & $61.4 \%$ & $64.3 \%$ & $73.3 \%$ & $65.2 \%$ \\
\hline & All & $100.0 \%$ & $100.0 \%$ & $100.0 \%$ & $100.0 \%$ \\
\hline \multirow{4}{*}{$\begin{array}{l}\text { Lack of walkways \& } \\
\text { sidewalks }\end{array}$} & Not a problem & $9.2 \%$ & $0.3 \%$ & $32.2 \%$ & $12.9 \%$ \\
\hline & Not a serious problem & $35.8 \%$ & $29.2 \%$ & $18.3 \%$ & $31.0 \%$ \\
\hline & A serious problem & $55.0 \%$ & $70.5 \%$ & $49.5 \%$ & $56.1 \%$ \\
\hline & All & $100.0 \%$ & $100.0 \%$ & $100.0 \%$ & $100.0 \%$ \\
\hline \multirow{4}{*}{ Price of travel } & Not a problem & $4.9 \%$ & $10.5 \%$ & $3.6 \%$ & $5.2 \%$ \\
\hline & Not a serious problem & $29.0 \%$ & $21.2 \%$ & $43.1 \%$ & $32.9 \%$ \\
\hline & A serious problem & $66.1 \%$ & $68.3 \%$ & $53.3 \%$ & $61.8 \%$ \\
\hline & All & $100.0 \%$ & $100.0 \%$ & $100.0 \%$ & $100.0 \%$ \\
\hline \multirow{4}{*}{$\begin{array}{l}\text { Aggressive \& } \\
\text { distracted drivers }\end{array}$} & Not a problem & $1.7 \%$ & $14.1 \%$ & $5.0 \%$ & $4.7 \%$ \\
\hline & Not a serious problem & $30.6 \%$ & $40.0 \%$ & $48.0 \%$ & $39.8 \%$ \\
\hline & A serious problem & $67.7 \%$ & $45.9 \%$ & $47.0 \%$ & $55.4 \%$ \\
\hline & All & $100.0 \%$ & $100.0 \%$ & $100.0 \%$ & $100.0 \%$ \\
\hline \multirow{4}{*}{ Safety concerns } & Not a problem & $13.3 \%$ & $11.6 \%$ & $17.3 \%$ & $14.2 \%$ \\
\hline & Not a serious problem & $24.7 \%$ & $47.7 \%$ & $38.3 \%$ & $32.2 \%$ \\
\hline & A serious problem & $62.0 \%$ & $40.7 \%$ & $44.5 \%$ & $53.6 \%$ \\
\hline & All & $100.0 \%$ & $100.0 \%$ & $100.0 \%$ & $100.0 \%$ \\
\hline
\end{tabular}




\subsection{Race and Ethnicity}

Table 4.8 presents results on attitudes for transit markets based on race and ethnicity for the U.S. as a whole. For both Non-Hispanic Whites and Non-Hispanic Blacks, the most important two issues are access to and availability of transit and the price of travel. For Hispanics, the price of travel also is the most important issue, but the second most important issue is safety concerns.

More Hispanics than either Non-Hispanic Whites or Non-Hispanic Blacks see lacking walkways and sidewalks and aggressive and distracted drivers as a serious problem. At the same time, fewer Hispanics than either Non-Hispanic Whites or Non-Hispanic Blacks view highway congestion and access to and availability of transit as a serious problem. Almost three-quarters of Non-Hispanic Blacks see safety concerns as a serious problem, but only 17.9 percent of Non-Hispanic Whites do.

Table 4.8. Attitudes of U.S. Transit Markets by Race and Ethnicity

\begin{tabular}{|c|c|c|c|c|c|c|}
\hline \multirow{2}{*}{\multicolumn{2}{|c|}{ Issues and Attributes }} & \multicolumn{4}{|c|}{ Race and Ethnicity } & \multirow[b]{2}{*}{ Total } \\
\hline & & Hispanic & $\begin{array}{c}\text { Non- } \\
\text { Hispanic } \\
\text { White }\end{array}$ & $\begin{array}{c}\text { Non- } \\
\text { Hispanic } \\
\text { Black }\end{array}$ & $\begin{array}{l}\text { Non- } \\
\text { Hispanic } \\
\text { Other }\end{array}$ & \\
\hline \multirow{7}{*}{$\begin{array}{l}\text { Most important } \\
\text { issue }\end{array}$} & Highway congestion & $9.2 \%$ & $9.0 \%$ & $4.7 \%$ & $7.0 \%$ & $7.5 \%$ \\
\hline & Access \& availability of transit & $18.8 \%$ & $47.9 \%$ & $27.3 \%$ & $34.5 \%$ & $32.2 \%$ \\
\hline & Lack of walkways \& sidewalks & $4.3 \%$ & $3.4 \%$ & $4.4 \%$ & $2.7 \%$ & $3.9 \%$ \\
\hline & Price of travel & $35.9 \%$ & $20.5 \%$ & $40.6 \%$ & $32.7 \%$ & $32.4 \%$ \\
\hline & Aggressive \& distracted drivers & $8.9 \%$ & $8.9 \%$ & $7.0 \%$ & $12.6 \%$ & $8.5 \%$ \\
\hline & Safety concerns & $22.8 \%$ & $10.2 \%$ & $16.0 \%$ & $10.5 \%$ & $15.5 \%$ \\
\hline & All & $100.0 \%$ & $100.0 \%$ & $100.0 \%$ & $100.0 \%$ & $100.0 \%$ \\
\hline \multirow{4}{*}{$\begin{array}{l}\text { Highway } \\
\text { congestion }\end{array}$} & Not a problem & $14.3 \%$ & $6.1 \%$ & $1.9 \%$ & -- & $7.5 \%$ \\
\hline & Not a serious problem & $57.8 \%$ & $33.8 \%$ & $37.8 \%$ & $36.7 \%$ & $42.7 \%$ \\
\hline & A serious problem & $27.9 \%$ & $60.1 \%$ & $60.2 \%$ & $63.3 \%$ & $49.8 \%$ \\
\hline & All & $100.0 \%$ & $100.0 \%$ & $100.0 \%$ & $100.0 \%$ & $100.0 \%$ \\
\hline \multirow{4}{*}{$\begin{array}{l}\text { Access to \& } \\
\text { availability of } \\
\text { transit }\end{array}$} & Not a problem & $13.3 \%$ & $10.6 \%$ & $18.9 \%$ & $16.6 \%$ & $13.9 \%$ \\
\hline & Not a serious problem & $46.5 \%$ & $12.8 \%$ & $21.5 \%$ & $19.5 \%$ & $21.0 \%$ \\
\hline & A serious problem & $40.2 \%$ & $76.6 \%$ & $59.6 \%$ & $63.9 \%$ & $65.1 \%$ \\
\hline & All & $100.0 \%$ & $100.0 \%$ & $100.0 \%$ & $100.0 \%$ & $100.0 \%$ \\
\hline \multirow{4}{*}{$\begin{array}{l}\text { Lack of } \\
\text { walkways \& } \\
\text { sidewalks }\end{array}$} & Not a problem & $3.1 \%$ & $27.5 \%$ & $13.8 \%$ & $3.0 \%$ & $13.9 \%$ \\
\hline & Not a serious problem & $23.1 \%$ & $37.2 \%$ & $41.8 \%$ & $11.2 \%$ & $33.5 \%$ \\
\hline & A serious problem & $73.8 \%$ & $35.3 \%$ & $44.4 \%$ & $85.8 \%$ & $52.5 \%$ \\
\hline & All & $100.0 \%$ & $100.0 \%$ & $100.0 \%$ & $100.0 \%$ & $100.0 \%$ \\
\hline \multirow{4}{*}{ Price of travel } & Not a problem & $6.8 \%$ & $3.8 \%$ & $4.1 \%$ & $10.6 \%$ & $5.3 \%$ \\
\hline & Not a serious problem & $31.6 \%$ & $42.7 \%$ & $32.1 \%$ & $23.8 \%$ & $33.5 \%$ \\
\hline & A serious problem & $61.6 \%$ & $53.5 \%$ & $63.8 \%$ & $65.6 \%$ & $61.2 \%$ \\
\hline & All & $100.0 \%$ & $100.0 \%$ & $100.0 \%$ & $100.0 \%$ & $100.0 \%$ \\
\hline \multirow{4}{*}{$\begin{array}{l}\text { Aggressive \& } \\
\text { distracted } \\
\text { drivers }\end{array}$} & Not a problem & $7.9 \%$ & $5.3 \%$ & $1.4 \%$ & $4.2 \%$ & $4.8 \%$ \\
\hline & Not a serious problem & $32.1 \%$ & $51.1 \%$ & $49.7 \%$ & $4.0 \%$ & $40.1 \%$ \\
\hline & A serious problem & $60.1 \%$ & $43.6 \%$ & $49.0 \%$ & $91.8 \%$ & $55.1 \%$ \\
\hline & All & $100.0 \%$ & $100.0 \%$ & $100.0 \%$ & $100.0 \%$ & $100.0 \%$ \\
\hline \multirow{4}{*}{$\begin{array}{l}\text { Safety } \\
\text { concerns }\end{array}$} & Not a problem & $12.9 \%$ & $16.0 \%$ & $14.6 \%$ & $14.3 \%$ & $14.2 \%$ \\
\hline & Not a serious problem & $35.3 \%$ & $66.1 \%$ & $11.3 \%$ & $15.0 \%$ & $32.2 \%$ \\
\hline & A serious problem & $51.8 \%$ & $17.9 \%$ & $74.1 \%$ & $70.6 \%$ & $53.6 \%$ \\
\hline & All & $100.0 \%$ & $100.0 \%$ & $100.0 \%$ & $100.0 \%$ & $100.0 \%$ \\
\hline
\end{tabular}




\subsection{Frequency of Transit Use}

Table 4.9 presents results on attitudes for transit markets based on frequency of transit use for the U.S. as a whole. All three frequency-based transit markets are similar in their views on the most important issue, though the proportion of transit trip makers who view safety concerns as the most important appears to decrease with the frequency of transit use.

Four of the six issues are considered to be a serious problem by a larger proportion of those who use transit at least 10 times a month than the least frequent users of transit. For example, 69.9 percent of the most frequent users and 65.6 percent of those of medium frequency see access to and availability of transit a serious problem, compared to 40.6 percent of the least frequent users.

Table 4.9. Attitudes of U.S. Transit Markets by Frequency of Transit Use

\begin{tabular}{|c|c|c|c|c|c|c|}
\hline \multirow{2}{*}{\multicolumn{2}{|c|}{ Issues and Attributes }} & \multicolumn{4}{|c|}{ Monthly Frequency of Transit Use } & \multirow[b]{2}{*}{ Total } \\
\hline & & \multirow{2}{*}{\begin{tabular}{r}
\multicolumn{1}{c}{$\begin{array}{c}\text { Most } \\
\text { Frequent }\end{array}$} \\
$7.3 \%$
\end{tabular}} & \multirow{2}{*}{$\begin{array}{r}\begin{array}{c}\text { Medium } \\
\text { Frequency }\end{array} \\
6.0 \%\end{array}$} & \multirow{2}{*}{\begin{tabular}{r}
\multicolumn{1}{c}{$\begin{array}{c}\text { Least } \\
\text { Frequent }\end{array}$} \\
$11.8 \%$
\end{tabular}} & \multirow{2}{*}{$\begin{array}{r}\begin{array}{l}\text { Non- } \\
\text { User }\end{array} \\
6.6 \%\end{array}$} & \\
\hline \multirow{7}{*}{$\begin{array}{l}\text { Most } \\
\text { important } \\
\text { issue }\end{array}$} & Highway congestion & & & & & $7.4 \%$ \\
\hline & Access \& availability of transit & $37.6 \%$ & $29.7 \%$ & $25.2 \%$ & -- & $32.9 \%$ \\
\hline & Lack of walkways \& sidewalks & $4.5 \%$ & $3.5 \%$ & $5.0 \%$ & $1.0 \%$ & $4.2 \%$ \\
\hline & Price of travel & $31.7 \%$ & $32.8 \%$ & $27.8 \%$ & $52.5 \%$ & $31.7 \%$ \\
\hline & Aggressive \& distracted drivers & $7.8 \%$ & $9.9 \%$ & $7.2 \%$ & $10.2 \%$ & $8.6 \%$ \\
\hline & Safety concerns & $11.1 \%$ & $18.1 \%$ & $22.9 \%$ & $29.7 \%$ & $15.3 \%$ \\
\hline & All & $100.0 \%$ & $100.0 \%$ & $100.0 \%$ & $100.0 \%$ & $100.0 \%$ \\
\hline \multirow{4}{*}{$\begin{array}{l}\text { Highway } \\
\text { congestion }\end{array}$} & Not a problem & $6.8 \%$ & $7.1 \%$ & $11.0 \%$ & -- & $7.7 \%$ \\
\hline & Not a serious problem & $44.2 \%$ & $40.5 \%$ & $46.5 \%$ & $81.6 \%$ & $43.5 \%$ \\
\hline & A serious problem & $49.0 \%$ & $52.4 \%$ & $42.5 \%$ & $18.4 \%$ & $48.7 \%$ \\
\hline & All & $100.0 \%$ & $100.0 \%$ & $100.0 \%$ & $100.0 \%$ & $100.0 \%$ \\
\hline \multirow{4}{*}{$\begin{array}{l}\text { Access to \& } \\
\text { availability of } \\
\text { transit }\end{array}$} & Not a problem & $13.1 \%$ & $11.1 \%$ & $21.5 \%$ & -- & $13.2 \%$ \\
\hline & Not a serious problem & $17.0 \%$ & $23.4 \%$ & $38.0 \%$ & -- & $21.2 \%$ \\
\hline & A serious problem & $69.9 \%$ & $65.6 \%$ & $40.6 \%$ & -- & $65.7 \%$ \\
\hline & All & $100.0 \%$ & $100.0 \%$ & $100.0 \%$ & -- & $100.0 \%$ \\
\hline \multirow{4}{*}{$\begin{array}{l}\text { Lack of } \\
\text { walkways \& } \\
\text { sidewalks }\end{array}$} & Not a problem & $9.8 \%$ & $6.6 \%$ & $41.0 \%$ & -- & $13.5 \%$ \\
\hline & Not a serious problem & $16.6 \%$ & $65.3 \%$ & $17.0 \%$ & $100.0 \%$ & $32.4 \%$ \\
\hline & A serious problem & $73.6 \%$ & $28.1 \%$ & $42.0 \%$ & -- & $54.1 \%$ \\
\hline & All & $100.0 \%$ & $100.0 \%$ & $100.0 \%$ & $100.0 \%$ & $100.0 \%$ \\
\hline \multirow{4}{*}{$\begin{array}{l}\text { Price of } \\
\text { travel }\end{array}$} & Not a problem & $5.5 \%$ & $5.2 \%$ & $5.9 \%$ & $1.7 \%$ & $5.4 \%$ \\
\hline & Not a serious problem & $37.5 \%$ & $29.1 \%$ & $40.8 \%$ & $41.4 \%$ & $34.5 \%$ \\
\hline & A serious problem & $57.0 \%$ & $65.7 \%$ & $53.4 \%$ & $57.0 \%$ & $60.1 \%$ \\
\hline & All & $100.0 \%$ & $100.0 \%$ & $100.0 \%$ & $100.0 \%$ & $100.0 \%$ \\
\hline \multirow{4}{*}{$\begin{array}{l}\text { Aggressive \& } \\
\text { distracted } \\
\text { drivers }\end{array}$} & Not a problem & $3.5 \%$ & $6.0 \%$ & $5.9 \%$ & -- & $4.9 \%$ \\
\hline & Not a serious problem & $45.7 \%$ & $34.5 \%$ & $42.2 \%$ & $78.0 \%$ & $40.5 \%$ \\
\hline & A serious problem & $50.8 \%$ & $59.4 \%$ & $51.9 \%$ & $22.0 \%$ & $54.7 \%$ \\
\hline & All & $100.0 \%$ & $100.0 \%$ & $100.0 \%$ & $100.0 \%$ & $100.0 \%$ \\
\hline \multirow{4}{*}{$\begin{array}{l}\text { Safety } \\
\text { concerns }\end{array}$} & Not a problem & $8.6 \%$ & $12.7 \%$ & $26.9 \%$ & $16.4 \%$ & $13.9 \%$ \\
\hline & Not a serious problem & $33.9 \%$ & $31.8 \%$ & $35.6 \%$ & $8.7 \%$ & $33.2 \%$ \\
\hline & A serious problem & $57.5 \%$ & $55.6 \%$ & $37.5 \%$ & $74.9 \%$ & $52.9 \%$ \\
\hline & All & $100.0 \%$ & $100.0 \%$ & $100.0 \%$ & $100.0 \%$ & $100.0 \%$ \\
\hline
\end{tabular}




\subsection{Trip Purpose}

Table 4.10 presents results on attitudes for transit markets based on trip purpose for the U.S. as a whole. Except for the issue of safety concerns, each of the other issues is viewed as a serious problem by more transit trip makers for medical/dental purposes than for work purposes. The difference is particularly large for the price of travel, highway congestion, and lacking walkways and sidewalks. The issues of lacking walkway and sidewalks and aggressive and distracted drivers are viewed as serious by considerably more transit trip makers for the three identified purposes than those for all other purposes. At the same time, safety concerns are seen as serious by fewer transit trip makers for the three identified purposes than those for all other purposes.

Table 4.10. Attitudes of U.S. Transit Markets by Trip Purpose

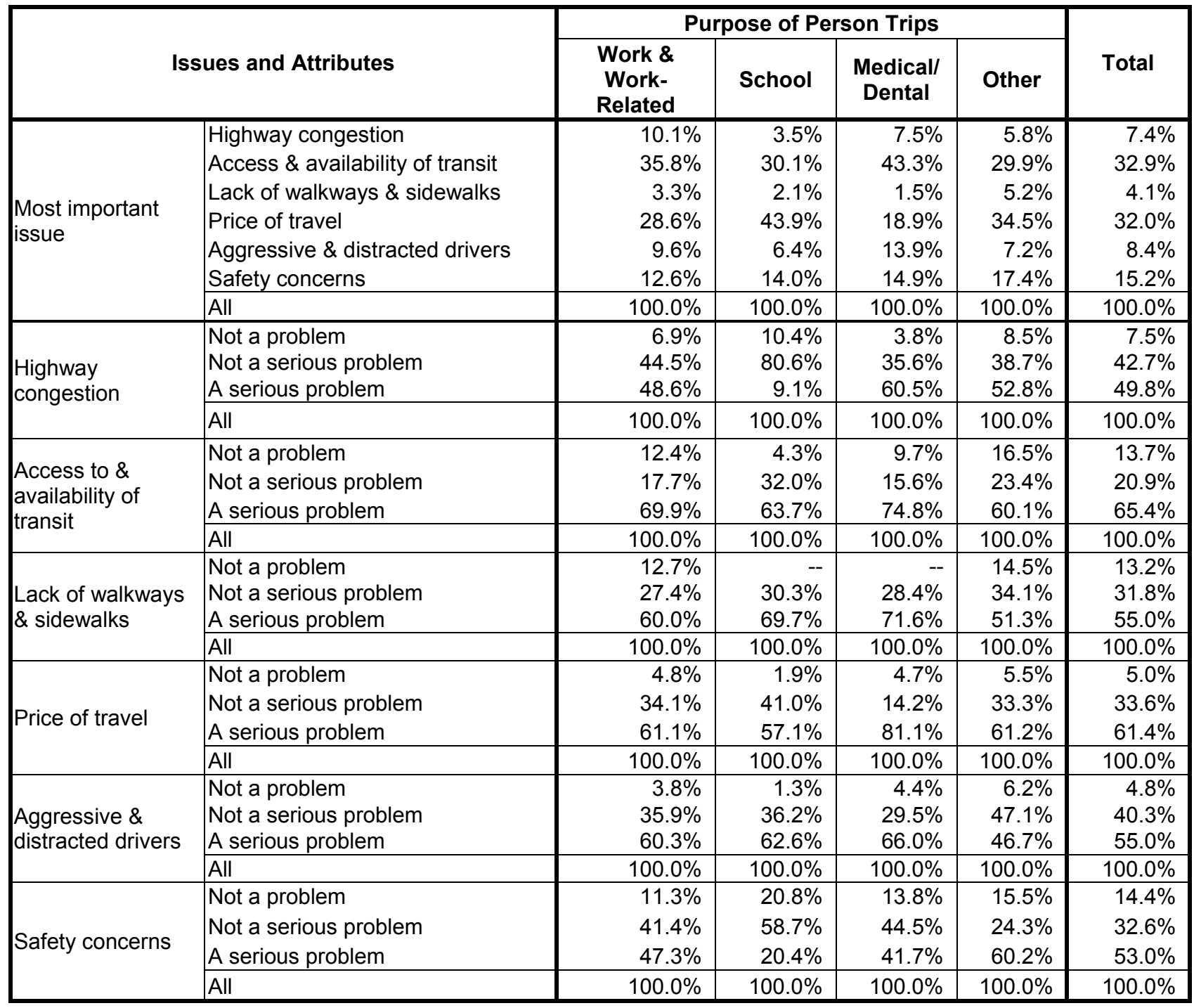




\subsection{Summary}

Table 4.11 summarizes the most important issues and the seriousness of individual issues for Florida and nine key transit markets selected from the eight sets of transit markets being assessed so far in this report. The nine key transit markets are:

- Non-drivers

- New immigrants

- Having medical conditions

- Income under $\$ 15,000$

- Zero vehicle Households

- Hispanics

- Non-Hispanic Blacks

- Most frequent users

- Work purposes

This summary is based on comparing the attitudes in Florida and each of the nine key transit markets with those in the U.S. as a whole:

- Florida - By far, the most important issue in Florida is access to and availability of transit, with 35.9 of transit trip makers see it being the most important issue. The least important issues are aggressive and distracted drivers and lack of walkways and sidewalks, with fewer than 10 percent of Floridians considering either of them as the most important issue.

Floridians are almost one-half as likely to rate the price of travel as the most important issue. They are more likely to view access to and availability of transit, aggressive and distracted drivers, or safety concerns as the most important issue. However, they are almost twice as likely to consider highway congestion and lacking walkways and sidewalks as the most important issue. In terms of the seriousness of each issue, Floridians have clearly different attitudes towards three of the six issues: access to and availability of transit, the price of travel, and safety concerns. All three issues appear to be not as serious to Floridians as to the U.S. as a whole.

- Non-Drivers - The most important issue is the price of travel, with 42.9 percent of transit trip makers viewing it as the most important issue. The second most important issue is access to and availability of transit, with 26.4 percent. The least important issues are highway congestion, aggressive and distracted drivers, and lacking walkways and sidewalks, with fewer than 10 percent. Non-drivers are almost twice as likely to see lacking walkways and sidewalks as the most important issue. They are one-third more likely to view the price of travel as the most important issue, but are less likely to see each of the other issues as the most important one. Non-drivers see the lack of walkways and sidewalks as a more serious problem than the entire transit market, at 96.8 percent. This is 73 percent higher than the 
comparative percentage for the entire transit market. Non-drivers, however, see each of the other five issues as being less serious than the entire transit market.

- New Immigrants - The most important issue to new immigrants is access to and availability of transit, at 29.4 percent. Relative to the entire transit market, however, new immigrants are 10 percent less likely to choose it as the most important issue. On the other hand, new immigrants are more than twice as likely to choose highway congestion and lacking walkways and sideways as the most important issue. They are also more likely to choose safety concerns as the most important issue. New immigrants also see lacking walkways and sidewalks as a more serious problem than the entire transit market, at 88.8 percent. This is 58 percent higher than the comparative percentage for the entire transit market. New immigrants, however, see each of the other five issues as being less serious than the entire transit market.

- Having Medical Conditions - The largest percentage of persons with medical conditions (32.1\%) chose access to and availability of transit as the most important issue. The price of travel and safety concerns are chosen as the most important issue by another 24 percent of them. Only 4.9 percent chose lacking walkways and sidewalks as the most important issue. Relative to the entire transit market, persons with medical conditions are more likely to choose either lacking walkways and sidewalks or aggressive and distracted drivers as the most important issue. They are significantly more likely to choose safety concerns as the most important issue. Persons with medical conditions have clearly different attitudes towards the seriousness of three of the six issues: the price of travel, lack of walkways and sidewalks, and safety concerns. They view all three issues as more serious than the entire transit market.

- Income under $\$ 15,000$ - The price of travel is the most important issue for the largest percent of transit trip makers with income under $\$ 15,000$ (32.5\%). Compared to the entire transit market, they are just as likely to choose it as the most important issue. However, they are more likely to choose aggressive and distracted drivers as the most important issue. Furthermore, they are far more likely to choose either safety concerns or lacking walkways and sidewalks as the most important issue. Persons with income under $\$ 15,000$ clearly have different attitudes towards the seriousness of two of the six issues: highway congestion and access to and availability of transit. They view both as being less serious as the entire transit market.

- Zero-Vehicle Households - To persons without household vehicles, the most important issue is access to and availability of transit, at 35.7 percent. The issue chosen by the smallest percent as the most important issue is highway congestion, at just 3.7 percent. Relative to the entire transit market, they are more likely to choose access to and availability 
of transit and safety concerns as the most important issue. In addition, they are far more likely to choose lacking walkways and sidewalks as the most important issue. They are just one-half as likely as the entire transit market to choose highway congestion as the most important issue. Persons without household vehicles clearly have different attitudes towards the seriousness of five of the six issues than the entire transit market. They view two of them being less serious: highway congestion and access to and availability of transit. However, they view the other three issues as being more serious: aggressive and distracted drivers, safety concerns, and the price of travel.

- Hispanics - For Hispanics, the most important issue is the price of travel, at 35.9 percent. The lowest percent chose lacking walkways and sidewalks, at just 4.3. Relative to the entire transit market, Hispanics are more likely to choose lacking walkways and sidewalks, aggressive and distracted drivers, and the price of travel as the most important issue. In addition, they are far more likely to choose highway congestion and safety concerns as the most important issue. Hispanics clearly have different attitudes towards the seriousness of two of the six issues than the entire transit market. They view lack of walkways and sidewalks as being more serious. However, they view highway congestion as being less serious.

- Non-Hispanics Blacks - The most important issue to the largest percentage of Non-Hispanic Blacks is the price of travel, at 40.6 percent. The issue chosen by the least percentage as the most important issue is lacking walkways and sidewalks, at just 4.4 percent. Relative to the entire transit market, they are more likely to choose lacking walkways and sidewalks and safety concerns as the most important issue. In addition, they are far more likely to choose the price of travel as the most important issue. Non-Hispanic Blacks see access to and availability of transit as being less serious, but they see highway congestion and the price of travel as being more serious issues.

- Most Frequent Users - The most important issue to the most frequent users of transit is access to and availability of transit, at 37.6 percent. This is also the issue that the most frequent users are more likely than the entire transit market to choose as the most important issue. They also are more likely to choose lacking walkways and sidewalks as the most important issue. The most frequent users have clearly different attitudes towards the seriousness of three of the six issues. All three are being seen as being more serious than by the entire transit market: lack of walkways and sideways, safety concerns, and access to and availability of transit.

- Work Purposes - The issue chosen by the largest percent of transit commuters as the most important is access to and availability of transit, at 35.8 percent. Lack of walkways and sidewalks is the least chosen as the most important issue, at just 3.3 percent. Relative to 
the entire transit market, they are more likely to choose access to and availability of transit and aggressive and distracted drivers as the most important issue. In addition, they are far more likely to choose highway congestion as the most important issue. Transit commuters have different attitudes towards the seriousness of three of the six issues. All three being seen as being more serious than the entire transit market: aggressive and distracted drivers, access to and availability of transit, and lack of walkways and sidewalks. 


\section{SOCIO-DEMOGRAPHICS OF TRANSIT MARKETS}

This section assesses transit markets in terms of their socio-demographic characteristics for the U.S. as a whole. The objective is to determine who the transit trip makers are in terms of their personal and household characteristics as well as where they live in terms of their locational characteristics. In addition to the six socio-demographic characteristics and frequency of transit use that are used to define transit markets in this study, the assessment in this section also considers person age and two locational characteristics: housing density in terms of housing units per square mile for census tracts, and whether a household is located in an urbanized area (UZA) and, if so, the population size of the UZA.

This section is organized with individual sections with one for each of the eight characteristics used to define transit markets. These characteristics are:

- Driver status

- Immigration status

- Medical conditions

- Household income

- Vehicle availability

- Race and ethnicity

- Frequency of transit use

- $\quad$ Trip purpose

\subsection{Driver Status}

Table 5.1 presents results on socio-demographics for transit markets by driver status. The discussion focuses on non-drivers through a comparison with drivers. The following highlights some of the results from this table:

- Person Age - Older adults (age 65+) are over-represented in the transit market among nondrivers, capturing 8.3 percent of the transit market among drivers and 12.1 percent of the transit market among non-drivers.

- Immigration Status - Non-drivers make disproportionately more transit trips as new immigrants, with 18.3 percent made by new immigrants. In comparison, 7.3 percent of the transit trips made by drivers are by new immigrants. At the same time, drivers and nondrivers make the same proportion of their transit trips (about 24\%) as older immigrants. 
Table 5.1. Socio-Demographics of U.S. Transit Markets by Driver Status

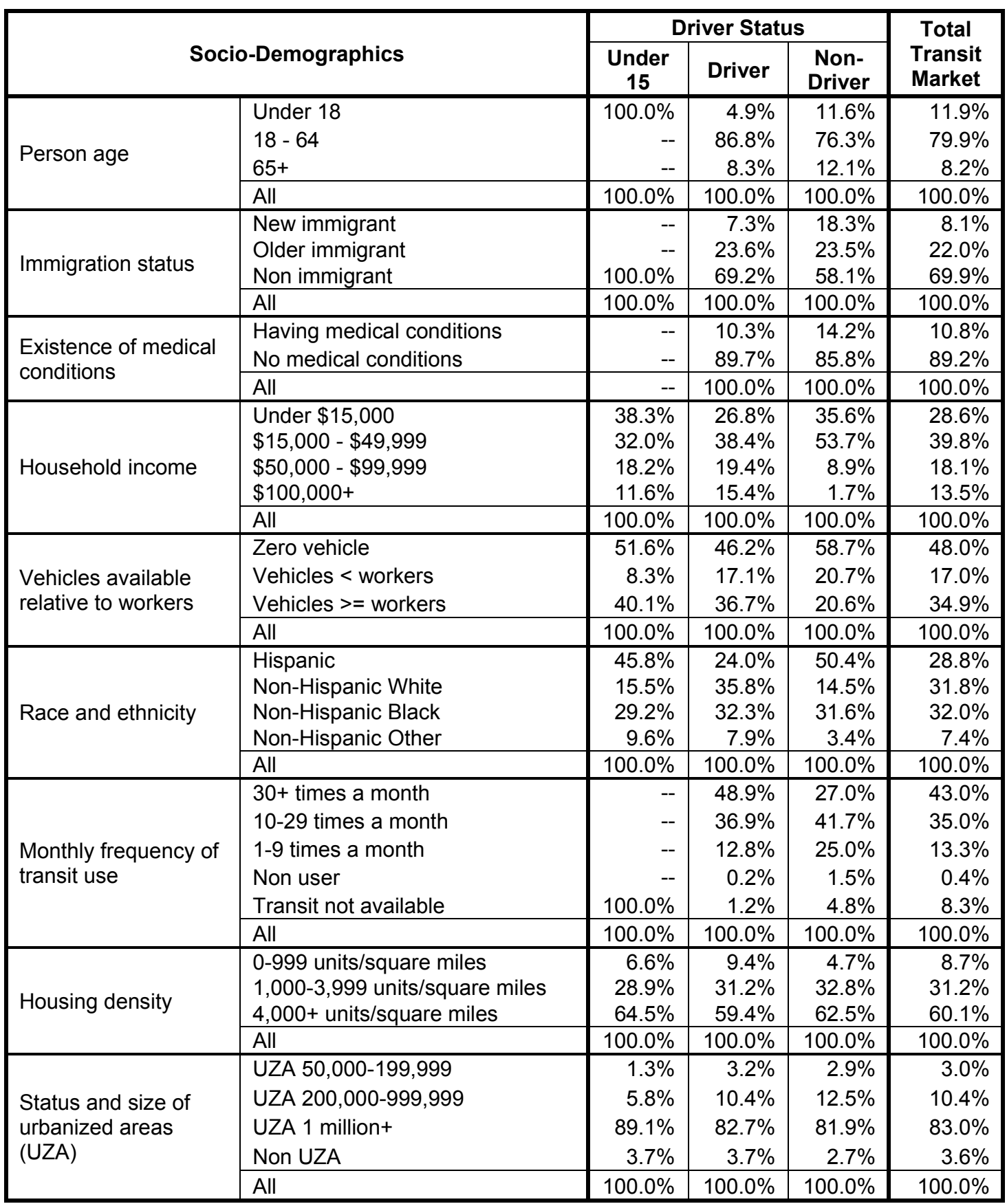

- Medical Conditions - Persons with medical conditions represent a larger transit market in the non-driver market $(14.2 \%)$ than in the driver market $(10.3 \%)$.

- Household Income - The non-driver market is dominated by those with household income under $\$ 50,000$. Those with household income under $\$ 15,000$ capture 35.6 percent of the non-driver market; and those with income $\$ 15,000-\$ 49,999$ capture 53.7 percent. Those with household income $\$ 50,000+$ capture only 10.6 percent of the non-driver market. 
Although the driver market also is dominated by the two lower income markets, those from higher income households capture a significant share of the market (34.8\%).

- Vehicle Availability - Persons from zero-vehicle households represent a large transit market for both driver and non-driver markets. However, they are a much larger transit market in the non-driver market $(58.7 \%)$ than in the driver market $(46.2 \%)$.

- Race and Ethnicity - Hispanics are a much larger transit market in the non-driver market than in the driver market. They capture about one-half of the non-driver market $(50.4 \%)$, but about one-quarter of the driver market (24.0\%). Non-Hispanic Blacks, on the other hand, represent a transit market that is similar in size for both driver and non-driver markets.

- Frequency of Transit Use - The most frequent users of transit (30+ times per month) are a much greater transit market in the driver market than in the non-driver market. They make almost one-half of the driver market $(48.9 \%)$ but slightly more than one-quarter of the nondriver market (27.0\%). The least frequent users (1-9 times per month), on the other hand, represent a transit market that is twice as large in the non-driver market as in the driver market, capturing 25.0 percent of the non-driver market but 12.8 percent of the driver market.

- Housing Density - Drivers and non-drivers do not differ much in where their transit trips are made in relation to housing density. They are similar in size in medium density areas (1,000-3,999 units/square miles). Low-density areas (under 1,000 units/square miles) are 4.7 percent of the non-driver market but 9.4 percent of the driver market.

- Urban Size - Drivers and non-drivers are similar in where their transit trips are made in relation to whether they live in an urbanized area and the size of the urbanized area. About 82 percent of the transit trips by non-drivers are made in urbanized areas with at least 1 million population; 10.4-12.5 percent are made in urbanized areas with population between 200,000 to 1 million; and the rest are equally split between non-urbanized areas and urbanized areas with population under 200,000.

\subsection{Immigration Status}

Table 5.2 presents results on the socio-demographics for transit markets by immigration status. The results relating to driver status and frequency of transit use are not discussed below. Data for some of the cross sections for them are blank perhaps as a result of them not being covered in the sample. The following highlights some of the results from this table: 
Table 5.2. Socio-Demographics of U.S. Transit Markets by Immigration Status

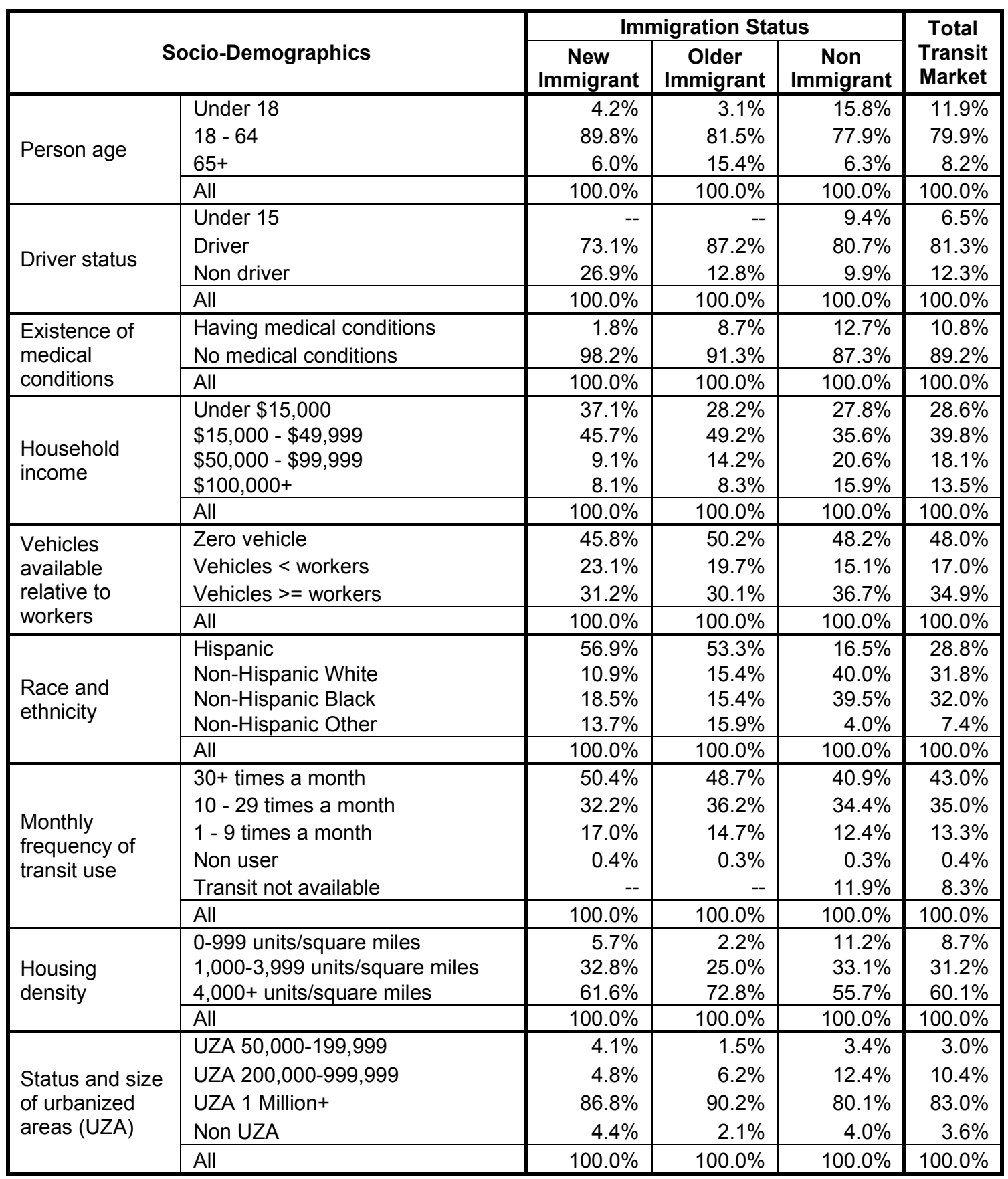

- Person Age - Persons ages18-64 years dominate all three markets. There are two noticeable differences across the three markets, however. Persons under age 18 are less than 5 percent of the two immigrant markets but 15.8 percent of the non-immigrant market. On the other hand, older adults are about 6 percent of the new-immigrant market and the non-immigrant market but 15.4 percent of the older immigrant market. 
- Driver Status - Non-drivers are more than one-quarter of the transit market among new immigrants $(26.9 \%)$. This percentage is much lower for the other two markets, with older immigrants at 12.8 percent and non-immigrants at 9.9 percent. One likely reason is that proportionally more new immigrants are non-drivers than the other markets.

- Medical Conditions - Persons with medical conditions contribute little to the new-immigrant market $(1.8 \%)$ but more to the older-immigrant market $(8.7 \%)$ and still more to the nonimmigrant market (12.7\%).

- Household Income - Persons with household income under $\$ 50,000$ dominate all three immigration-based transit markets. However, persons with a higher household income capture a larger share of the older-immigrant market (22.5\%) than the new-immigrant market $(17.2 \%)$ and capture an even greater share of the non-immigrant market $(36.5 \%)$.

- Vehicle Availability - Persons with zero vehicles capture a smaller share of the newimmigrant market than both older immigrants and non-immigrants. Persons with inadequate vehicles, however, capture a larger share of the new-immigrant market than both of the other two markets.

- Race and Ethnicity - Hispanics represent 56.9 percent of the new-immigrant market and 53.3 percent of the older-immigrant market. Hispanics capture about 16 percent of the nonimmigrant market and Non-Hispanic Others captures 4 percent, with the remaining 80 percent of the non-immigrant market evenly split between Non-Hispanic Whites and NonHispanic Blacks.

- Housing Density - Areas with the highest density (4,000+ housing units/square miles) dominate all three immigration-based markets, capturing 55.7 percent of the non-immigrant market, 61.6 percent of the new-immigrant market, and 72.8 percent of the older-immigrant market. When compared to the older-immigrant market, a larger portion of the newimmigrant market is captured by lower-density areas and a smaller portion captured by areas with the highest density.

- Urban Size - The largest urbanized areas dominate all three immigration-based transit markets, especially the immigrant markets. However, the results on non-urbanized areas and the smallest urbanized areas may not be good news for transit. The new-immigrant market appears to be close to the non-immigrant market than the older-immigrant market in terms of the proportion of each captured by non-urbanized areas and by the small-sized urbanized areas. Non-urbanized areas represent 4.4 percent of the new-immigrant market and 4.0 percent of the non-immigrant market but only 2.1 percent of the old-immigrant market. Similarly, urbanized areas with a population of 50,000-199,999 represent 4.1 
percent of the new-immigrant market and 3.4 percent of the non-immigrant market, but only 1.5 percent of the older-immigrant market.

\subsection{Medical Conditions}

Table 5.3 presents results on socio-demographics for transit markets by medical conditions. The following highlights some of the results from this table:

- Person Age - As one would expect, older adults (65+) make 16.7 percent of the transit trips by persons with medical conditions, compared to 8.0 percent of the trips by persons without any medical condition.

- $\quad$ Driver Status - Non-drivers are a larger transit market among persons with medical conditions $(16.7 \%)$ than among persons without medical conditions $(12.2 \%)$.

- Immigration Status - Immigrants capture a smaller portion of the transit trips among persons with medical conditions. The difference is particularly large for new immigrants; they capture only 1.5 percent of the transit trips by persons with medical conditions but 9.7 percent of those by persons without medical conditions.

- Household Income - The majority of the transit trips made by persons with medical conditions $(58.2 \%)$ are made by the poorest with household income under $\$ 15,000$. In contrast, the poorest make just under a quarter of the transit trips by persons without any medical conditions. At the other extreme, persons with household income $\$ 100,000+$ are only 1.4 percent of the transit trips by persons with medical conditions but 15.1 percent of the transit trips by persons without conditions.

- Vehicle Availability - Persons in zero-vehicle households make more than three-quarters $(76.0 \%)$ of the transit trips by persons with medical conditions, but 44.8 percent of the transit trips by persons without medical conditions.

- Race and Ethnicity - The transit markets based on medical conditions are largely similar with respect to their race and ethnicity composition.

- Frequency of Transit Use - The transit market among persons with medical conditions relies more on the least frequent users but less on the most frequent users than the transit market among persons without conditions. Close to one-quarter $(24.0 \%)$ of the transit trips made by persons with conditions are made by the least frequent users of transit (1-9 times per month), compared to 13.4 percent for persons without conditions. On the other hand, 34.9 percent of the transit trips made by persons with medical conditions are made by the most frequent users, compared to 48.3 percent for the market without medical conditions. 
Table 5.3. Socio-Demographics of U.S. Transit Markets by Medical Conditions

\begin{tabular}{|c|c|c|c|c|}
\hline \multirow{2}{*}{\multicolumn{2}{|c|}{ Socio-Demographics }} & \multicolumn{2}{|c|}{$\begin{array}{c}\text { Existence of Medical } \\
\text { Conditions }\end{array}$} & \multirow{2}{*}{$\begin{array}{l}\text { Total } \\
\text { Transit } \\
\text { Market }\end{array}$} \\
\hline & & $\begin{array}{l}\text { Having } \\
\text { Medical } \\
\text { Conditions } \\
\end{array}$ & $\begin{array}{c}\text { No } \\
\text { Medical } \\
\text { Conditions }\end{array}$ & \\
\hline \multirow{4}{*}{ Person age } & Under 18 & $0.1 \%$ & $4.8 \%$ & $11.9 \%$ \\
\hline & $18-64$ & $83.2 \%$ & $87.2 \%$ & $79.9 \%$ \\
\hline & $65+$ & $16.7 \%$ & $8.0 \%$ & $8.2 \%$ \\
\hline & All & $100.0 \%$ & $100.0 \%$ & $100.0 \%$ \\
\hline \multirow{4}{*}{ Driver status } & Under 15 & -- & -- & -- \\
\hline & Driver & $83.3 \%$ & $87.8 \%$ & $86.9 \%$ \\
\hline & Non driver & $16.7 \%$ & $12.2 \%$ & $13.1 \%$ \\
\hline & All & $100.0 \%$ & $100.0 \%$ & $100.0 \%$ \\
\hline \multirow{9}{*}{ Immigration status } & New immigrant & $1.5 \%$ & $9.7 \%$ & $8.1 \%$ \\
\hline & Older immigrant & $19.4 \%$ & $24.5 \%$ & $22.0 \%$ \\
\hline & Non immigrant & $79.2 \%$ & $65.8 \%$ & $69.9 \%$ \\
\hline & All & $100.0 \%$ & $100.0 \%$ & $100.0 \%$ \\
\hline & Under $\$ 15,000$ & $58.2 \%$ & $24.5 \%$ & $28.6 \%$ \\
\hline & $\$ 15,000-\$ 49,999$ & $29.8 \%$ & $41.5 \%$ & $39.8 \%$ \\
\hline & $\$ 50,000-\$ 99,999$ & $10.6 \%$ & $18.9 \%$ & $18.1 \%$ \\
\hline & $\$ 100,000+$ & $1.4 \%$ & $15.1 \%$ & $13.5 \%$ \\
\hline & All & $100.0 \%$ & $100.0 \%$ & $100.0 \%$ \\
\hline \multirow{4}{*}{$\begin{array}{l}\text { Vehicles available } \\
\text { relative to workers }\end{array}$} & Zero vehicle & $76.0 \%$ & $44.8 \%$ & $48.0 \%$ \\
\hline & Vehicles < workers & $5.0 \%$ & $18.8 \%$ & $17.0 \%$ \\
\hline & Vehicles $>=$ workers & $19.0 \%$ & $36.4 \%$ & $34.9 \%$ \\
\hline & All & $100.0 \%$ & $100.0 \%$ & $100.0 \%$ \\
\hline \multirow{5}{*}{ Race and ethnicity } & Hispanic & $25.9 \%$ & $27.3 \%$ & $28.8 \%$ \\
\hline & Non-Hispanic White & $33.5 \%$ & $33.0 \%$ & $31.8 \%$ \\
\hline & Non-Hispanic Black & $37.7 \%$ & $31.8 \%$ & $32.0 \%$ \\
\hline & Non-Hispanic Other & $2.9 \%$ & $7.9 \%$ & $7.4 \%$ \\
\hline & All & $100.0 \%$ & $100.0 \%$ & $100.0 \%$ \\
\hline \multirow{6}{*}{$\begin{array}{l}\text { Monthly frequency of } \\
\text { transit use }\end{array}$} & $30+$ times a month & $34.9 \%$ & $48.3 \%$ & $46.9 \%$ \\
\hline & 10 - 29 times a month & $40.5 \%$ & $37.9 \%$ & $38.2 \%$ \\
\hline & 1 - 9 times a month & $24.0 \%$ & $13.4 \%$ & $14.5 \%$ \\
\hline & Non user & $0.7 \%$ & $0.4 \%$ & $0.4 \%$ \\
\hline & Transit not available & -- & -- & -- \\
\hline & All & $100.0 \%$ & $100.0 \%$ & $100.0 \%$ \\
\hline \multirow{4}{*}{ Housing density } & 0-999 units/square miles & $9.3 \%$ & $8.7 \%$ & $8.7 \%$ \\
\hline & $1,000-3,999$ units/square miles & $44.8 \%$ & $29.9 \%$ & $31.2 \%$ \\
\hline & $4,000+$ units/square miles & $45.9 \%$ & $61.4 \%$ & $60.1 \%$ \\
\hline & All & $100.0 \%$ & $100.0 \%$ & $100.0 \%$ \\
\hline \multirow{5}{*}{$\begin{array}{l}\text { Status and size of } \\
\text { urbanized areas (UZA) }\end{array}$} & UZA 50,000-199,999 & $4.3 \%$ & $2.9 \%$ & $3.0 \%$ \\
\hline & UZA 200,000-999,999 & $17.7 \%$ & $9.9 \%$ & $10.4 \%$ \\
\hline & UZA 1 million+ & $72.0 \%$ & $83.9 \%$ & $83.0 \%$ \\
\hline & Non UZA & $6.0 \%$ & $3.3 \%$ & $3.6 \%$ \\
\hline & All & $100.0 \%$ & $100.0 \%$ & $100.0 \%$ \\
\hline
\end{tabular}

- Housing Density - Fewer of the transit trips by persons with medical conditions are made in areas of highest density (4,000 units/square miles), but more of their transit rips are made in areas of medium density (1,000-3,999 units/square miles). Specifically, persons with medical conditions make 45.9 percent of their transit trips as residents of areas with at least 
4,000 units per square mile, compared to 61.4 percent for persons without medical conditions.

- Urban Size - Consistent with the results relating to housing density, fewer of the transit trips by persons with medical conditions are made in the largest urbanized areas and more of their transit trips are made outside of urbanized areas or in smaller urbanized areas than persons without medical conditions. For example, persons with medical conditions make 72.0 percent of their transit trips as residents of the largest urbanized areas, compared to 83.9 percent for persons without medical conditions.

\subsection{Household Income}

Table 5.4 presents results on socio-demographics for transit markets by household income. The following highlights some of the results from this table:

- Person Age - Older adults make a higher proportion of the transit trips in markets of lower household income. Older adults capture 2.9 percent of the high-income market, 3.4 percent of the middle high-income market, 8.9 percent of the middle low-income market, and 12.4 percent of the low-income market.

- Driver Status - Non-drivers capture about 16 percent of the lower income markets, 6.0 percent of the middle high-income market, and just 1.5 percent of the high-income market.

- Immigration Status - Immigrants represent a much larger transit market among persons with household income under $\$ 50,000$ than among persons with higher income. For example, immigrants are 32.2 percent of the low-income market, compared to 18.3 percent of the high-income market.

- Medical Conditions - Persons with medical conditions represent a larger portion of the transit markets with lower household income. The portion of transit trips made by persons with medical conditions decreases from 22.2 percent for the low-income market, 7.9 percent for middle low-income market, 6.3 percent for the middle high-income market, and just 1.1 percent for the high-income market.

- Vehicle Availability - Persons in zero-vehicle households make almost three-quarters of the transit trips in the low-income market, and this share decreases to 50.4 percent for the middle low-income market, 27.3 percent for the middle high-income market, and 16.7 percent for the high-income market. 
Table 5.4. Socio-Demographics of U.S. Transit Markets by Household Income

\begin{tabular}{|c|c|c|c|c|c|c|}
\hline & \multirow{2}{*}{$\begin{array}{c}\text { Total } \\
\text { Transit } \\
\text { Market }\end{array}$} \\
\hline \multicolumn{2}{|c|}{ Socio-Demographics } & $\begin{array}{l}\text { Under } \\
\$ 15,000\end{array}$ & $\begin{array}{l}\$ 15,000- \\
\$ 49,999\end{array}$ & $\begin{array}{l}\$ 50,000- \\
\$ 99,999\end{array}$ & $\$ 100,000+$ & \\
\hline \multirow{4}{*}{ Person age } & Under 18 & $12.5 \%$ & $13.1 \%$ & $10.9 \%$ & $9.3 \%$ & $11.9 \%$ \\
\hline & $18-64$ & $75.2 \%$ & $78.0 \%$ & $85.7 \%$ & $87.7 \%$ & $79.9 \%$ \\
\hline & $65+$ & $12.4 \%$ & $8.9 \%$ & $3.4 \%$ & $2.9 \%$ & $8.2 \%$ \\
\hline & All & $100.0 \%$ & $100.0 \%$ & $100.0 \%$ & $100.0 \%$ & $100.0 \%$ \\
\hline \multirow{4}{*}{ Driver status } & Under 15 & $8.7 \%$ & $5.2 \%$ & $6.6 \%$ & $5.6 \%$ & $6.5 \%$ \\
\hline & Driver & $76.1 \%$ & $78.3 \%$ & $87.4 \%$ & $92.9 \%$ & $81.3 \%$ \\
\hline & Non driver & $15.2 \%$ & $16.4 \%$ & $6.0 \%$ & $1.5 \%$ & $12.3 \%$ \\
\hline & All & $100.0 \%$ & $100.0 \%$ & $100.0 \%$ & $100.0 \%$ & $100.0 \%$ \\
\hline \multirow{4}{*}{$\begin{array}{l}\text { Immigration } \\
\text { status }\end{array}$} & New immigrant & $10.4 \%$ & $9.3 \%$ & $4.0 \%$ & $4.8 \%$ & $8.1 \%$ \\
\hline & Older immigrant & $21.8 \%$ & $27.6 \%$ & $17.2 \%$ & $13.5 \%$ & $22.0 \%$ \\
\hline & Non immigrant & $67.8 \%$ & $63.1 \%$ & $78.7 \%$ & $81.7 \%$ & $69.9 \%$ \\
\hline & All & $100.0 \%$ & $100.0 \%$ & $100.0 \%$ & $100.0 \%$ & $100.0 \%$ \\
\hline \multirow{3}{*}{$\begin{array}{l}\text { Existence of } \\
\text { medical } \\
\text { conditions }\end{array}$} & Having medical conditions & $22.2 \%$ & $7.9 \%$ & $6.3 \%$ & $1.1 \%$ & $10.8 \%$ \\
\hline & No medical conditions & $77.8 \%$ & $92.1 \%$ & $93.7 \%$ & $98.9 \%$ & $89.2 \%$ \\
\hline & All & $100.0 \%$ & $100.0 \%$ & $100.0 \%$ & $100.0 \%$ & $100.0 \%$ \\
\hline \multirow{4}{*}{$\begin{array}{l}\text { Vehicles } \\
\text { available } \\
\text { relative to } \\
\text { workers }\end{array}$} & Zero vehicle & $74.1 \%$ & $50.4 \%$ & $27.3 \%$ & $16.7 \%$ & $48.0 \%$ \\
\hline & Vehicles < workers & $8.2 \%$ & $17.6 \%$ & $27.1 \%$ & $23.7 \%$ & $17.0 \%$ \\
\hline & Vehicles $>=$ workers & $17.7 \%$ & $31.9 \%$ & $45.6 \%$ & $59.6 \%$ & $34.9 \%$ \\
\hline & All & $100.0 \%$ & $100.0 \%$ & $100.0 \%$ & $100.0 \%$ & $100.0 \%$ \\
\hline \multirow{5}{*}{$\begin{array}{l}\text { Race and } \\
\text { ethnicity }\end{array}$} & Hispanic & $32.7 \%$ & $39.5 \%$ & $14.9 \%$ & $5.7 \%$ & $28.8 \%$ \\
\hline & Non-Hispanic White & $13.0 \%$ & $21.7 \%$ & $59.7 \%$ & $65.8 \%$ & $31.8 \%$ \\
\hline & Non-Hispanic Black & $51.4 \%$ & $31.0 \%$ & $17.9 \%$ & $14.2 \%$ & $32.0 \%$ \\
\hline & Non-Hispanic Other & $2.9 \%$ & $7.9 \%$ & $7.6 \%$ & $14.4 \%$ & $7.4 \%$ \\
\hline & All & $100.0 \%$ & $100.0 \%$ & $100.0 \%$ & $100.0 \%$ & $100.0 \%$ \\
\hline \multirow{6}{*}{$\begin{array}{l}\text { Monthly } \\
\text { frequency of } \\
\text { transit use }\end{array}$} & $30+$ times a month & $35.7 \%$ & $44.6 \%$ & $47.5 \%$ & $50.4 \%$ & $43.0 \%$ \\
\hline & $10-29$ times a month & $36.0 \%$ & $34.8 \%$ & $35.0 \%$ & $30.8 \%$ & $35.0 \%$ \\
\hline & 1 - 9 times a month & $17.6 \%$ & $12.7 \%$ & $8.8 \%$ & $11.1 \%$ & $13.3 \%$ \\
\hline & Non user & $0.6 \%$ & $0.3 \%$ & $0.3 \%$ & $0.3 \%$ & $0.4 \%$ \\
\hline & Transit not available & $10.1 \%$ & $7.5 \%$ & $8.4 \%$ & $7.4 \%$ & $8.3 \%$ \\
\hline & All & $100.0 \%$ & $100.0 \%$ & $100.0 \%$ & $100.0 \%$ & $100.0 \%$ \\
\hline \multirow{4}{*}{$\begin{array}{l}\text { Housing } \\
\text { density }\end{array}$} & 0-999 units/square miles & $11.7 \%$ & $5.3 \%$ & $7.3 \%$ & $13.2 \%$ & $8.7 \%$ \\
\hline & $1,000-3,999$ units/square miles & $34.9 \%$ & $26.9 \%$ & $30.5 \%$ & $34.4 \%$ & $31.2 \%$ \\
\hline & $4,000+$ units/square miles & $53.4 \%$ & $67.8 \%$ & $62.2 \%$ & $52.4 \%$ & $60.1 \%$ \\
\hline & All & $100.0 \%$ & $100.0 \%$ & $100.0 \%$ & $100.0 \%$ & $100.0 \%$ \\
\hline \multirow{5}{*}{$\begin{array}{l}\text { Status and } \\
\text { size of } \\
\text { urbanized } \\
\text { areas (UZA) }\end{array}$} & UZA 50,000-199,999 & $5.3 \%$ & $2.4 \%$ & $2.1 \%$ & $1.4 \%$ & $3.0 \%$ \\
\hline & UZA 200,000-999,999 & $16.4 \%$ & $10.5 \%$ & $4.6 \%$ & $2.7 \%$ & $10.4 \%$ \\
\hline & UZA 1 million+ & $75.1 \%$ & $84.3 \%$ & $89.8 \%$ & $89.6 \%$ & $83.0 \%$ \\
\hline & Non UZA & $3.3 \%$ & $2.8 \%$ & $3.5 \%$ & $6.2 \%$ & $3.6 \%$ \\
\hline & All & $100.0 \%$ & $100.0 \%$ & $100.0 \%$ & $100.0 \%$ & $100.0 \%$ \\
\hline
\end{tabular}

- Race and Ethnicity - Hispanics and Non-Hispanic Blacks capture 84.1 percent of the lowincome market, 70.5 percent of the middle low-income market, 32.8 percent of the middle high-income market, and 19.9 percent of the high-income market. 
- Frequency of Transit Use - Higher income markets rely more on the most frequent users of transit. The most frequent users make 50.4 percent of transit trips by persons with household income at least $\$ 100,000$ but 35.7 percent by persons with household income under $\$ 15,000$.

- Housing Density - The pattern of transit trips across ranges of housing density appears to be similar between the two middle income markets and between the low-income market and the high-income market. In addition, there are notable differences in this pattern between these two groups of income-based markets. It is particularly curious as to why the two markets with extreme levels of income are similar in the spatial distribution of their transit trips across areas of different housing density.

- Urban Size - A larger proportion of the lower income markets occur in urbanized areas of population under 1 million. The proportion is 4.1 percent for the high-income market, 6.7 percent for the middle high-income market, 12.9 percent for the middle low-income market, and 21.7 percent for the low-income market.

\subsection{Vehicle Availability}

Table 5.5 presents results on socio-demographics for transit markets by vehicle availability. The following highlights some of the results from this table:

- Person Age - Older adults represent a larger transit market among persons without household vehicles. The percentage of transit trips by older adults is 11.8 percent among persons without vehicles, 1.6 percent among persons with inadequate vehicles, and 6.6 percent among persons with adequate vehicles. The particularly small percentage among persons with inadequate vehicles results from the fact that not many older adults live in households that have at least one vehicle available and have more workers than vehicles.

- Driver Status - Non-drivers make about 15 percent of the transit trips by households without vehicles or with inadequate vehicles but only 7.2 percent of those by households with adequate vehicles.

- Immigration Status - Immigrants are slightly larger transit markets among households with inadequate vehicles than among either households without vehicles or households with adequate vehicles.

- Medical Conditions - Persons with medical conditions are a much larger transit market among households without vehicles than among households with vehicles. For example, 17.0 percent of the transit trips taken by households without vehicles are by persons with 
medical conditions, compared to just 3.1 percent by households with inadequate vehicles and 6.0 percent by households with adequate vehicles.

Table 5.5. Socio-Demographics of U.S. Transit Markets by Vehicle Availability

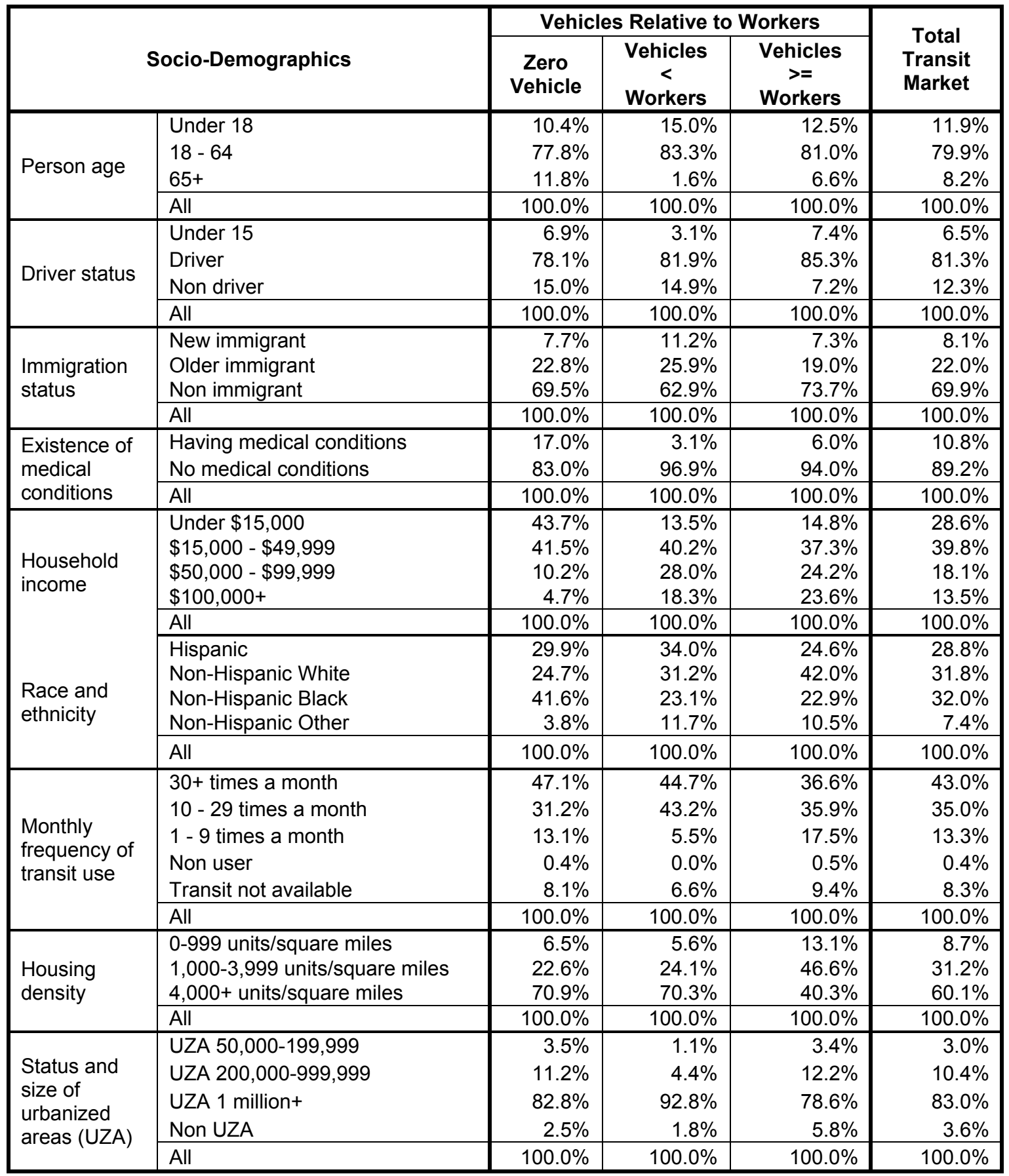

- Household Income - Households with income under \$15,000 represent a transit market that is more than three times as large for zero-vehicle households as for households with vehicles. For example, transit trips taken by households with income under $\$ 15,000$ are 
43.7 percent of those by households without vehicles, compared to 13.5-14.8 percent by households with vehicles.

- $\quad$ Race and Ethnicity - Hispanics represent about one-quarter of the transit market among households with adequate vehicles but a larger market among households with lower vehicle availability. Non-Hispanic Blacks are a much larger transit market among households without vehicles than among households with vehicles. For example, they make 41.6 percent of the transit trips by households without vehicles, compared to just 22.9 percent of those by households with adequate vehicles. Non-Hispanic Whites make a larger proportion of the transit trips among households with higher levels of vehicle availability. For example, they make 42.0 percent of the transit trips by households with adequate vehicles but 24.7 percent of those by households without vehicles.

- Frequency of Transit Use - The most frequent users of transit are a smaller transit market among households with higher levels of vehicle availability. They make 47.1 percent of the transit trips by households without vehicles and 36.6 percent of those by households with adequate vehicles. Less frequent users, on the other hand, represent larger transit markets among households with adequate vehicles than among households without vehicles. For example, the least frequent users make 13.1 percent of the transit trips by households without vehicles, compared to 17.5 percent by households with adequate vehicles.

- Location - Census tracts with housing density at least 4,000 units per square mile are about 70 percent of the transit trips taken by households without vehicles or with inadequate vehicles but are about 40 percent of those by households with adequate vehicles. The opposite relationships hold for census tracts with lower housing density.

\subsection{Race and Ethnicity}

Table 5.6 presents results on socio-demographics for transit markets by race and ethnicity. The following highlights some of the results from this table:

- Person Age - The young (under 18) and older adults (65+) are a larger transit market among Hispanics than either Non-Hispanic Whites or Non-Hispanic Blacks. The percent of transit trips by these two age groups is 26.6 percent for Hispanics, compared to 16.3 percent for Non-Hispanic Whites and 17.0 percent for Non-Hispanic Blacks.

- Driver Status - Non-drivers and children are much larger transit markets among Hispanics than either among Non-Hispanic Blacks or among Non-Hispanic Whites. Non-drivers represent 22.0 percent of the transit trips by Hispanics, compared to 12.4 percent by NonHispanic Blacks and 5.7 percent by Non-Hispanic Whites. Similarly, children capture 10.5 
percent of the Hispanic market, 6.0 percent of the Non-Hispanic Black market, and 3.2 percent of the Non-Hispanic White market.

- Immigration Status - Immigrants are a major source of ridership among Hispanics, but a much smaller transit market among Non-Hispanic Blacks and Non-Hispanic Whites. The percentage of transit trips taken by new immigrants is 16.9 percent among Hispanics but only 4.7 percent among Non-Hispanic Blacks and 2.8 percent among Non-Hispanic Whites. Similarly, the percentage of transit trips taken by older immigrants is 42.0 percent among Hispanics, 10.4 percent among Non-Hispanic Blacks, and 10.6 percent among NonHispanic Whites.

- Medical Conditions - Persons with medical conditions are a slightly larger transit market among Non-Hispanic Blacks (12.7\%) and Non-Hispanic Whites (11.1\%) than among Hispanics (10.4\%).

- Household Income - Persons from households with low income dominate the transit markets among Hispanics and Non-Hispanic Blacks. Persons with income under \$15,000 are one-third of the transit market among Hispanics (33.3\%), with another 54.5 percent of the Hispanics market captured by persons with income $\$ 15,000-\$ 49,999$. Together, these two low-income segments represent 87.8 percent of the transit market among Hispanics. Similarly, these two low-income segments represent 84.2 percent of the transit market among Non-Hispanic Blacks.

One difference between Hispanics and Non-Hispanic Blacks is the relative importance of the two low income segments. For Hispanics, persons with income $\$ 15,000-\$ 49,999$ are the larger market than the other segment. For Non-Hispanic Blacks, persons with income under $\$ 15,000$ are the larger market. In contrast to both Hispanics and non-Hispanic blacks, the majority of the transit trips by Non-Hispanic Whites (61.3\%) are taken by persons with income at least $\$ 50,000$, with persons with income $\$ 50,000-\$ 99,999$ contributing 34.2 percent and persons with income $\$ 100,000+$ contributing 27.1 percent.

- Vehicle Availability - Persons without household vehicles are a very large source of transit trips for all three major markets based on race and ethnicity, particularly for Hispanics and Non-Hispanic Blacks. The percent of transit trips taken by persons without household vehicles is 37.8 among Non-Hispanic Whites, compared to 50.6 percent among Hispanics and 63.2 percent among Non-Hispanic Blacks.

- Frequency of Transit Use - Persons who use transit at least once but fewer than 30 times a month represent about one-half of the transit trips among each of the three major transit markets based on race and ethnicity, with about 14 percent from the least frequent users and the remainder of 36 percent from persons who use transit 10-29 times a month. 
Table 5.6. Socio-Demographics of U.S. Transit Markets by Race and Ethnicity

\begin{tabular}{|c|c|c|c|c|c|c|}
\hline \multirow{2}{*}{\multicolumn{2}{|c|}{ Socio-Demographics }} & \multicolumn{4}{|c|}{ Race and Ethnicity } & \multirow{2}{*}{$\begin{array}{l}\text { Total } \\
\text { Transit } \\
\text { Market }\end{array}$} \\
\hline & & \multirow{2}{*}{$\begin{array}{r}\text { Hispanic } \\
17.4 \%\end{array}$} & $\begin{array}{c}\text { Non- } \\
\text { Hispanic } \\
\text { White }\end{array}$ & $\begin{array}{c}\text { Non- } \\
\text { Hispanic } \\
\text { Black }\end{array}$ & $\begin{array}{l}\text { Non- } \\
\text { Hispanic } \\
\text { Other }\end{array}$ & \\
\hline \multirow{4}{*}{ Person age } & Under 18 & & $7.7 \%$ & $10.2 \%$ & $14.1 \%$ & $11.9 \%$ \\
\hline & $18-64$ & $73.5 \%$ & $83.7 \%$ & $83.0 \%$ & $78.0 \%$ & $79.9 \%$ \\
\hline & $65+$ & $9.2 \%$ & $8.6 \%$ & $6.8 \%$ & $7.9 \%$ & $8.2 \%$ \\
\hline & All & $100.0 \%$ & $100.0 \%$ & $100.0 \%$ & $100.0 \%$ & $100.0 \%$ \\
\hline \multirow{4}{*}{ Driver status } & Under 15 & $10.5 \%$ & $3.2 \%$ & $6.0 \%$ & $8.5 \%$ & $6.5 \%$ \\
\hline & Driver & $67.5 \%$ & $91.1 \%$ & $81.6 \%$ & $85.7 \%$ & $81.3 \%$ \\
\hline & Non driver & $22.0 \%$ & $5.7 \%$ & $12.4 \%$ & $5.8 \%$ & $12.3 \%$ \\
\hline & All & $100.0 \%$ & $100.0 \%$ & $100.0 \%$ & $100.0 \%$ & $100.0 \%$ \\
\hline \multirow{4}{*}{$\begin{array}{l}\text { Immigration } \\
\text { status }\end{array}$} & New immigrant & $16.9 \%$ & $2.8 \%$ & $4.7 \%$ & $15.3 \%$ & $8.1 \%$ \\
\hline & Older immigrant & $42.0 \%$ & $10.6 \%$ & $10.4 \%$ & $47.1 \%$ & $22.0 \%$ \\
\hline & Non immigrant & $41.1 \%$ & $86.6 \%$ & $84.8 \%$ & $37.6 \%$ & $69.9 \%$ \\
\hline & All & $100.0 \%$ & $100.0 \%$ & $100.0 \%$ & $100.0 \%$ & $100.0 \%$ \\
\hline \multirow{3}{*}{$\begin{array}{l}\text { Existence of } \\
\text { medical } \\
\text { conditions }\end{array}$} & Having medical conditions & $10.4 \%$ & $11.1 \%$ & $12.7 \%$ & $4.3 \%$ & $10.8 \%$ \\
\hline & No medical conditions & $89.6 \%$ & $88.9 \%$ & $87.3 \%$ & $95.7 \%$ & $89.2 \%$ \\
\hline & All & $100.0 \%$ & $100.0 \%$ & $100.0 \%$ & $100.0 \%$ & $100.0 \%$ \\
\hline \multirow{5}{*}{$\begin{array}{l}\text { Household } \\
\text { income }\end{array}$} & Under $\$ 15,000$ & $33.3 \%$ & $11.8 \%$ & $46.3 \%$ & $11.8 \%$ & $28.6 \%$ \\
\hline & $\$ 15,000-\$ 49,999$ & $54.5 \%$ & $26.8 \%$ & $37.9 \%$ & $42.9 \%$ & $39.8 \%$ \\
\hline & $\$ 50,000-\$ 99,999$ & $9.5 \%$ & $34.2 \%$ & $10.1 \%$ & $19.1 \%$ & $18.1 \%$ \\
\hline & $\$ 100,000+$ & $2.6 \%$ & $27.1 \%$ & $5.7 \%$ & $26.1 \%$ & $13.5 \%$ \\
\hline & All & $100.0 \%$ & $100.0 \%$ & $100.0 \%$ & $100.0 \%$ & $100.0 \%$ \\
\hline \multirow{4}{*}{$\begin{array}{l}\text { Vehicles } \\
\text { available } \\
\text { relative to } \\
\text { workers }\end{array}$} & Zero vehicle & $50.6 \%$ & $37.8 \%$ & $63.2 \%$ & $24.9 \%$ & $48.0 \%$ \\
\hline & Vehicles < workers & $19.6 \%$ & $16.3 \%$ & $11.9 \%$ & $26.2 \%$ & $17.0 \%$ \\
\hline & Vehicles $>=$ workers & $29.7 \%$ & $45.9 \%$ & $24.8 \%$ & $49.0 \%$ & $34.9 \%$ \\
\hline & All & $100.0 \%$ & $100.0 \%$ & $100.0 \%$ & $100.0 \%$ & $100.0 \%$ \\
\hline \multirow{6}{*}{$\begin{array}{l}\text { Monthly } \\
\text { frequency of } \\
\text { transit use }\end{array}$} & $30+$ times a month & $35.6 \%$ & $47.5 \%$ & $44.1 \%$ & $38.6 \%$ & $43.0 \%$ \\
\hline & $10-29$ times a month & $36.2 \%$ & $33.7 \%$ & $34.4 \%$ & $41.5 \%$ & $35.0 \%$ \\
\hline & 1 - 9 times a month & $14.0 \%$ & $14.1 \%$ & $13.6 \%$ & $9.4 \%$ & $13.3 \%$ \\
\hline & Non user & $0.2 \%$ & $0.4 \%$ & $0.6 \%$ & $0.4 \%$ & $0.4 \%$ \\
\hline & Transit not available & $14.0 \%$ & $4.4 \%$ & $7.3 \%$ & $10.1 \%$ & $8.3 \%$ \\
\hline & All & $100.0 \%$ & $100.0 \%$ & $100.0 \%$ & $100.0 \%$ & $100.0 \%$ \\
\hline \multirow{4}{*}{$\begin{array}{l}\text { Housing } \\
\text { density }\end{array}$} & 0-999 units/square miles & $3.7 \%$ & $15.1 \%$ & $7.3 \%$ & $5.8 \%$ & $8.7 \%$ \\
\hline & $1,000-3,999$ units/square miles & $28.9 \%$ & $36.0 \%$ & $30.4 \%$ & $29.4 \%$ & $31.2 \%$ \\
\hline & $4,000+$ units/square miles & $67.4 \%$ & $48.9 \%$ & $62.3 \%$ & $64.9 \%$ & $60.1 \%$ \\
\hline & All & $100.0 \%$ & $100.0 \%$ & $100.0 \%$ & $100.0 \%$ & $100.0 \%$ \\
\hline \multirow{5}{*}{$\begin{array}{l}\text { Status and } \\
\text { size of } \\
\text { urbanized } \\
\text { areas (UZA) }\end{array}$} & UZA 50,000-199,999 & $2.5 \%$ & $5.5 \%$ & $1.7 \%$ & $0.9 \%$ & $3.0 \%$ \\
\hline & UZA 200,000-999,999 & $10.9 \%$ & $8.9 \%$ & $12.2 \%$ & $6.7 \%$ & $10.4 \%$ \\
\hline & UZA 1 million+ & $83.2 \%$ & $78.1 \%$ & $85.4 \%$ & $91.2 \%$ & $83.0 \%$ \\
\hline & Non UZA & $3.4 \%$ & $7.5 \%$ & $0.6 \%$ & $1.1 \%$ & $3.6 \%$ \\
\hline & All & $100.0 \%$ & $100.0 \%$ & $100.0 \%$ & $100.0 \%$ & $100.0 \%$ \\
\hline
\end{tabular}

- Location - As one would expect, transit trips are highly concentrated in the largest urbanized areas and in areas with the highest housing density. Urbanized areas with a population at least 1 million represent 83.2 percent of the trips taken by Hispanics, 85.4 percent taken by Non-Hispanic Blacks, and 78.1 percent taken by Non-Hispanic Whites. Similarly, census tracts with at least 4,000 housing units per square mile represent 67.4 
percent of the trips taken by Hispanics, 62.3 percent taken by Non-Hispanic Blacks, and 48.9 percent by Non-Hispanic Whites.

However, a sizable portion of the transit trips taken by Non-Hispanic Whites occur in the smallest urbanized areas, outside urbanized areas, and in areas with lowest housing density. Urbanized areas with population under 200,000 and non-urbanized areas are 13.0 percent of the transit trips taken by Non-Hispanic Whites. Similarly, areas with housing density under 1,000 units per square mile are 15.1 percent of their transit trips.

\subsection{Frequency of Transit Use}

Table 5.7 presents results on socio-demographics for transit markets by frequency of transit use for the U.S. as a whole. The following highlights some of the results for regular users (i.e., used transit at least once per month):

- Person Age - Older adults are a far more significant source of transit ridership for the market of the least frequent users than either of the two markets of more frequent users. They make 17.9 percent of the transit trips by the least frequent users but well below 10 percent of those by more frequent users.

- Immigration Status - The pattern of transit use among the three immigrant statuses does not differ much across the three transit markets based on frequency of transit use.

- Medical Conditions - A higher proportion of the transit trips taken by persons with medical conditions are by transit users of lower frequency.

- Household Income - The source of ridership in terms of household income varies quite a bit across the transit markets based on frequency of usage. The percent of transit trips taken by persons with household income under $\$ 15,000$ is lowest $(23.2 \%)$ among the most frequent users, is higher (29.4\%) among users of medium frequency, and is highest (37.8\%) among the least frequent users. On the other hand, the percent of transit trips taken by persons with household income at least $\$ 50,000$ is highest $(36.1 \%)$ among the most frequent users, lower (30.8\%) among the users of medium frequency, and lowest $(24.0 \%)$ among the least frequent users.

- Vehicle Availability - The contribution of households without any vehicles is in the same magnitude across the three transit markets of different frequency of usage. These three markets differ mainly in how much ridership comes from households with inadequate vehicles and households with adequate vehicles. Households with adequate vehicles are a far larger source of ridership among the least frequent users (1-9 times per month) than more frequent users. These households represent 46.3 percent of the transit trips taken by 
the least frequent users, compared to 29.9 percent by the most frequent users $(30+$ times per month) and 36.1 percent by those who use transit 10-29 times per month. At the same time, well under 10 percent of the transit trips by the least frequent users $(7.4 \%)$ come from households with inadequate vehicles, compared to $18.4-21.8$ percent by the more frequent users.

Table 5.7. Socio-Demographics of U.S. Transit Markets by Frequency of Transit Use

\begin{tabular}{|c|c|c|c|c|c|c|c|}
\hline \multirow{2}{*}{\multicolumn{2}{|c|}{ Socio-Demographics }} & \multicolumn{5}{|c|}{ Monthly Frequency of Transit Use } & \multirow[b]{2}{*}{$\begin{array}{c}\text { Total } \\
\text { Transit } \\
\text { Market }\end{array}$} \\
\hline & & $\begin{array}{c}30+ \\
\text { Times/ } \\
\text { Month }\end{array}$ & $\begin{array}{l}10-29 \\
\text { Times/ } \\
\text { Month }\end{array}$ & $\begin{array}{c}1 \text { - } 9 \\
\text { Times/ } \\
\text { Month }\end{array}$ & $\begin{array}{l}\text { Non } \\
\text { User }\end{array}$ & $\begin{array}{c}\text { Transit } \\
\text { not } \\
\text { Available }\end{array}$ & \\
\hline \multirow{4}{*}{ Person age } & Under 18 & $5.2 \%$ & $3.3 \%$ & $4.8 \%$ & -- & $100.0 \%$ & $11.9 \%$ \\
\hline & $18-64$ & $89.2 \%$ & $89.0 \%$ & $77.3 \%$ & $49.0 \%$ & -- & $79.9 \%$ \\
\hline & $65+$ & $5.5 \%$ & $7.7 \%$ & $17.9 \%$ & $51.0 \%$ & -- & $8.2 \%$ \\
\hline & All & $100.0 \%$ & $100.0 \%$ & $100.0 \%$ & $100.0 \%$ & $100.0 \%$ & $100.0 \%$ \\
\hline \multirow{4}{*}{ Driver status } & Under 15 & -- & -- & -- & -- & $81.6 \%$ & $6.5 \%$ \\
\hline & Driver & $92.6 \%$ & $86.0 \%$ & $78.0 \%$ & $54.3 \%$ & $11.6 \%$ & $81.3 \%$ \\
\hline & Non driver & $7.4 \%$ & $14.0 \%$ & $22.0 \%$ & $45.7 \%$ & $6.8 \%$ & $12.3 \%$ \\
\hline & All & $100.0 \%$ & $100.0 \%$ & $100.0 \%$ & $100.0 \%$ & $100.0 \%$ & $100.0 \%$ \\
\hline \multirow{4}{*}{$\begin{array}{l}\text { Immigration } \\
\text { status }\end{array}$} & New immigrant & $9.1 \%$ & $7.2 \%$ & $10.0 \%$ & $7.9 \%$ & -- & $8.1 \%$ \\
\hline & Older immigrant & $24.0 \%$ & $22.3 \%$ & $23.7 \%$ & $21.5 \%$ & -- & $22.0 \%$ \\
\hline & Non immigrant & $66.9 \%$ & $70.5 \%$ & $66.3 \%$ & $70.6 \%$ & $100.0 \%$ & $69.9 \%$ \\
\hline & All & $100.0 \%$ & $100.0 \%$ & $100.0 \%$ & $100.0 \%$ & $100.0 \%$ & $100.0 \%$ \\
\hline \multirow{3}{*}{$\begin{array}{l}\text { Existence of } \\
\text { medical } \\
\text { conditions }\end{array}$} & Having medical conditions & $8.1 \%$ & $11.5 \%$ & $17.9 \%$ & $17.8 \%$ & -- & $10.8 \%$ \\
\hline & No medical conditions & $91.9 \%$ & $88.5 \%$ & $82.1 \%$ & $82.2 \%$ & -- & $89.2 \%$ \\
\hline & All & $100.0 \%$ & $100.0 \%$ & $100.0 \%$ & $100.0 \%$ & -- & $100.0 \%$ \\
\hline \multirow{5}{*}{$\begin{array}{l}\text { Household } \\
\text { income }\end{array}$} & Under $\$ 15,000$ & $23.2 \%$ & $29.4 \%$ & $37.8 \%$ & $44.3 \%$ & $34.0 \%$ & $28.6 \%$ \\
\hline & $\$ 15,000-\$ 49,999$ & $40.7 \%$ & $39.8 \%$ & $38.2 \%$ & $32.9 \%$ & $35.4 \%$ & $39.8 \%$ \\
\hline & $\$ 50,000-\$ 99,999$ & $20.0 \%$ & $18.5 \%$ & $12.3 \%$ & $12.9 \%$ & $18.4 \%$ & $18.1 \%$ \\
\hline & $\$ 100,000+$ & $16.1 \%$ & $12.3 \%$ & $11.7 \%$ & $9.9 \%$ & $12.2 \%$ & $13.5 \%$ \\
\hline & All & $100.0 \%$ & $100.0 \%$ & $100.0 \%$ & $100.0 \%$ & $100.0 \%$ & $100.0 \%$ \\
\hline \multirow{4}{*}{$\begin{array}{l}\text { Vehicles } \\
\text { available } \\
\text { relative to } \\
\text { workers }\end{array}$} & Zero vehicle & $51.7 \%$ & $42.1 \%$ & $46.4 \%$ & $53.5 \%$ & $46.1 \%$ & $48.0 \%$ \\
\hline & Vehicles < workers & $18.4 \%$ & $21.8 \%$ & $7.4 \%$ & $0.4 \%$ & $14.0 \%$ & $17.0 \%$ \\
\hline & Vehicles $>=$ workers & $29.9 \%$ & $36.1 \%$ & $46.3 \%$ & $46.1 \%$ & $39.9 \%$ & $34.9 \%$ \\
\hline & All & $100.0 \%$ & $100.0 \%$ & $100.0 \%$ & $100.0 \%$ & $100.0 \%$ & $100.0 \%$ \\
\hline \multirow{5}{*}{$\begin{array}{l}\text { Race and } \\
\text { ethnicity }\end{array}$} & Hispanic & $24.2 \%$ & $29.6 \%$ & $29.7 \%$ & $15.5 \%$ & $47.4 \%$ & $28.8 \%$ \\
\hline & Non-Hispanic White & $36.7 \%$ & $31.4 \%$ & $34.0 \%$ & $30.4 \%$ & $16.9 \%$ & $31.8 \%$ \\
\hline & Non-Hispanic Black & $32.5 \%$ & $30.5 \%$ & $31.2 \%$ & $46.7 \%$ & $27.0 \%$ & $32.0 \%$ \\
\hline & Non-Hispanic Other & $6.6 \%$ & $8.5 \%$ & $5.0 \%$ & $7.4 \%$ & $8.6 \%$ & $7.4 \%$ \\
\hline & All & $100.0 \%$ & $100.0 \%$ & $100.0 \%$ & $100.0 \%$ & $100.0 \%$ & $100.0 \%$ \\
\hline \multirow{4}{*}{$\begin{array}{l}\text { Housing } \\
\text { density }\end{array}$} & 0-999 units/square miles & $6.9 \%$ & $11.0 \%$ & $11.2 \%$ & $27.2 \%$ & $7.3 \%$ & $8.7 \%$ \\
\hline & $1,000-3,999$ units/square miles & $26.6 \%$ & $33.3 \%$ & $43.0 \%$ & $53.1 \%$ & $28.2 \%$ & $31.2 \%$ \\
\hline & $4,000+$ units/square miles & $66.5 \%$ & $55.7 \%$ & $45.8 \%$ & $19.7 \%$ & $64.4 \%$ & $60.1 \%$ \\
\hline & All & $100.0 \%$ & $100.0 \%$ & $100.0 \%$ & $100.0 \%$ & $100.0 \%$ & $100.0 \%$ \\
\hline \multirow{5}{*}{$\begin{array}{l}\text { Status and } \\
\text { size of } \\
\text { urbanized } \\
\text { areas (UZA) }\end{array}$} & UZA 50,000-199,999 & $1.4 \%$ & $4.5 \%$ & $5.5 \%$ & $15.7 \%$ & $2.6 \%$ & $3.0 \%$ \\
\hline & UZA 200,000-999,999 & $8.8 \%$ & $12.3 \%$ & $11.5 \%$ & $10.9 \%$ & $6.3 \%$ & $10.4 \%$ \\
\hline & UZA 1 million+ & $86.2 \%$ & $80.3 \%$ & $77.1 \%$ & $67.3 \%$ & $87.6 \%$ & $83.0 \%$ \\
\hline & Non UZA & $3.6 \%$ & $3.0 \%$ & $5.9 \%$ & $6.1 \%$ & $3.5 \%$ & $3.6 \%$ \\
\hline & All & $100.0 \%$ & $100.0 \%$ & $100.0 \%$ & $100.0 \%$ & $100.0 \%$ & $100.0 \%$ \\
\hline
\end{tabular}


- Race and Ethnicity - The different race and ethnicity groups do not differ much in their contribution of ridership to the three transit markets based on frequency of usage. They do differ in their contribution to the transit trips taken by non-users.

- Location - The most frequent users appear to be far more concentrated in the largest urbanized areas and in census tracts with the highest housing density. At the same time, the least frequent users tend to be more concentrated in the smaller urbanized areas and in census tracts with lower housing density. For the most frequent users, two-thirds (66.5\%) of their transit trips occur in areas with housing density at least 4,000 units per square mile; and 86.2 percent of their transit trips happen in urbanized areas with population at least 1 million. For the least frequent users, on the other hand, 54.2 percent of their transit trips are taken in areas with housing density under 4,000 units per square mile; and 11.4 percent of their transit trips occur in non-urbanized areas and urbanized areas with population under 200,000 , compared to 5.0 percent for the most frequent users.

\subsection{Trip Purpose}

Table 5.8 presents results on socio-demographics for transit markets by trip purpose for the U.S. as a whole. The following highlights some of the results from this table:

- Person Age - Older adults (65+) are 13.7 percent of the total population. In comparison, they make 3.3 percent of the transit trips for work purposes and 22.0 percent for medical and dental purposes. These are expected largely because most of them are fully retired but have many health care needs. It is somewhat unexpected, however, that persons ages 1864 years make almost one-half of all transit trips for school purposes.

- Driver Status - Non-drivers are 10.8 percent of the total population but make only 3.2 percent of the transit trips for work purposes. At the same time, they make almost onequarter of the transit trips for medical and dental purposes. One possible reason is that many non-drivers are not in the workforce and many have health issues that require them to visit health professionals more frequently than others. What is surprising is that non-drivers capture a larger portion of the transit trips for medical/dental purposes than older adults. One reason for the surprise is that the non-driver population is smaller than the older adult population; another is that older adults are typically considered to have more health issues than the general population.

In terms of transit trips for school purposes, the results show that 31.7 percent are made by persons 15-17 years old. The results related to person age in this table show that persons younger than 18 years of age make 51.7 percent of all transit trips for school purpose. The results related to driver status show that persons younger than 15 years of age make 20.0 
percent of all transit trips for school purposes. The difference represents the proportion of transit trips for school purposes taken by persons ages 15-17.

Table 5.8. Socio-Demographics of U.S. Transit Markets by Trip Purpose

\begin{tabular}{|c|c|c|c|c|c|c|}
\hline & \multirow[b]{2}{*}{ Socio-Demographics } & \multicolumn{4}{|c|}{ Purpose of Person Trips } & \multirow{2}{*}{$\begin{array}{c}\text { Total } \\
\text { Transit } \\
\text { Market }\end{array}$} \\
\hline & & $\begin{array}{c}\text { Work/Work } \\
\text { Related }\end{array}$ & School & $\begin{array}{l}\text { Medical } \\
\text { \& Dental }\end{array}$ & Other & \\
\hline \multirow{4}{*}{ Person age } & Under 18 & $1.0 \%$ & $51.7 \%$ & $9.2 \%$ & $13.2 \%$ & $11.9 \%$ \\
\hline & $18-64$ & $95.7 \%$ & $48.1 \%$ & $68.9 \%$ & $75.7 \%$ & $79.9 \%$ \\
\hline & $65+$ & $3.3 \%$ & $0.2 \%$ & $22.0 \%$ & $11.2 \%$ & $8.2 \%$ \\
\hline & All & $100.0 \%$ & $100.0 \%$ & $100.0 \%$ & $100.0 \%$ & $100.0 \%$ \\
\hline \multirow{4}{*}{ Driver status } & Under 15 & -- & $20.0 \%$ & $7.6 \%$ & $8.7 \%$ & $6.5 \%$ \\
\hline & Driver & $96.8 \%$ & $66.5 \%$ & $67.8 \%$ & $74.7 \%$ & $81.3 \%$ \\
\hline & Non driver & $3.2 \%$ & $13.5 \%$ & $24.5 \%$ & $16.6 \%$ & $12.3 \%$ \\
\hline & All & $100.0 \%$ & $100.0 \%$ & $100.0 \%$ & $100.0 \%$ & $100.0 \%$ \\
\hline \multirow{4}{*}{$\begin{array}{l}\text { Immigration } \\
\text { status }\end{array}$} & New immigrant & $8.5 \%$ & $12.1 \%$ & $5.3 \%$ & $7.7 \%$ & $8.1 \%$ \\
\hline & Older immigrant & $29.0 \%$ & $8.9 \%$ & $24.0 \%$ & $19.0 \%$ & $22.0 \%$ \\
\hline & Non immigrant & $62.5 \%$ & $79.0 \%$ & $70.7 \%$ & $73.3 \%$ & $69.9 \%$ \\
\hline & All & $100.0 \%$ & $100.0 \%$ & $100.0 \%$ & $100.0 \%$ & $100.0 \%$ \\
\hline \multirow{3}{*}{$\begin{array}{l}\text { Existence of } \\
\text { medical } \\
\text { conditions }\end{array}$} & Having medical conditions & $4.7 \%$ & $2.4 \%$ & $35.0 \%$ & $14.0 \%$ & $10.8 \%$ \\
\hline & No medical conditions & $95.3 \%$ & $97.6 \%$ & $65.0 \%$ & $86.0 \%$ & $89.2 \%$ \\
\hline & All & $100.0 \%$ & $100.0 \%$ & $100.0 \%$ & $100.0 \%$ & $100.0 \%$ \\
\hline \multirow{5}{*}{$\begin{array}{l}\text { Household } \\
\text { income }\end{array}$} & Under $\$ 15,000$ & $20.7 \%$ & $19.6 \%$ & $37.7 \%$ & $34.5 \%$ & $28.6 \%$ \\
\hline & $\$ 15,000-\$ 49,999$ & $36.4 \%$ & $42.8 \%$ & $38.3 \%$ & $41.5 \%$ & $39.8 \%$ \\
\hline & $\$ 50,000-\$ 99,999$ & $21.8 \%$ & $19.4 \%$ & $19.3 \%$ & $15.6 \%$ & $18.1 \%$ \\
\hline & $\$ 100,000+$ & $21.2 \%$ & $18.2 \%$ & $4.7 \%$ & $8.4 \%$ & $13.5 \%$ \\
\hline & All & $100.0 \%$ & $100.0 \%$ & $100.0 \%$ & $100.0 \%$ & $100.0 \%$ \\
\hline \multirow{4}{*}{$\begin{array}{l}\text { Vehicles } \\
\text { available } \\
\text { relative to } \\
\text { workers }\end{array}$} & Zero vehicle & $35.4 \%$ & $25.4 \%$ & $64.1 \%$ & $59.4 \%$ & $48.0 \%$ \\
\hline & Vehicles < workers & $26.6 \%$ & $29.7 \%$ & $6.2 \%$ & $8.7 \%$ & $17.0 \%$ \\
\hline & Vehicles $>=$ workers & $38.0 \%$ & $45.0 \%$ & $29.7 \%$ & $31.9 \%$ & $34.9 \%$ \\
\hline & All & $100.0 \%$ & $100.0 \%$ & $100.0 \%$ & $100.0 \%$ & $100.0 \%$ \\
\hline \multirow{5}{*}{$\begin{array}{l}\text { Race and } \\
\text { ethnicity }\end{array}$} & Hispanic & $25.9 \%$ & $36.0 \%$ & $35.2 \%$ & $28.5 \%$ & $28.8 \%$ \\
\hline & Non-Hispanic White & $37.3 \%$ & $28.6 \%$ & $38.1 \%$ & $28.0 \%$ & $31.8 \%$ \\
\hline & Non-Hispanic Black & $26.6 \%$ & $28.0 \%$ & $24.3 \%$ & $37.4 \%$ & $32.0 \%$ \\
\hline & Non-Hispanic Other & $10.2 \%$ & $7.4 \%$ & $2.5 \%$ & $6.1 \%$ & $7.4 \%$ \\
\hline & All & $100.0 \%$ & $100.0 \%$ & $100.0 \%$ & $100.0 \%$ & $100.0 \%$ \\
\hline \multirow{6}{*}{$\begin{array}{l}\text { Monthly } \\
\text { frequency of } \\
\text { transit use }\end{array}$} & $30+$ times a month & $54.5 \%$ & $36.6 \%$ & $29.6 \%$ & $37.9 \%$ & $43.0 \%$ \\
\hline & 10 - 29 times a month & $40.6 \%$ & $24.5 \%$ & $31.2 \%$ & $32.9 \%$ & $35.0 \%$ \\
\hline & 1 - 9 times a month & $4.5 \%$ & $4.1 \%$ & $29.1 \%$ & $19.3 \%$ & $13.3 \%$ \\
\hline & Non user & $0.2 \%$ & -- & $2.3 \%$ & $0.2 \%$ & $0.4 \%$ \\
\hline & Transit not available & $0.1 \%$ & $34.8 \%$ & $7.9 \%$ & $9.7 \%$ & $8.3 \%$ \\
\hline & All & $100.0 \%$ & $100.0 \%$ & $100.0 \%$ & $100.0 \%$ & $100.0 \%$ \\
\hline \multirow{4}{*}{$\begin{array}{l}\text { Housing } \\
\text { density }\end{array}$} & 0-999 units/square miles & $10.7 \%$ & $11.9 \%$ & $5.4 \%$ & $6.9 \%$ & $8.7 \%$ \\
\hline & $1,000-3,999$ units/square mi. & $33.2 \%$ & $26.0 \%$ & $41.8 \%$ & $29.6 \%$ & $31.2 \%$ \\
\hline & $4,000+$ units/square miles & $56.1 \%$ & $62.0 \%$ & $52.8 \%$ & $63.5 \%$ & $60.1 \%$ \\
\hline & All & $100.0 \%$ & $100.0 \%$ & $100.0 \%$ & $100.0 \%$ & $100.0 \%$ \\
\hline \multirow{5}{*}{$\begin{array}{l}\text { Status and } \\
\text { size of } \\
\text { urbanized } \\
\text { areas (UZA) }\end{array}$} & UZA 50,000-199,999 & $3.1 \%$ & $4.0 \%$ & $5.7 \%$ & $2.5 \%$ & $3.0 \%$ \\
\hline & UZA 200,000-999,999 & $8.4 \%$ & $7.7 \%$ & $9.8 \%$ & $12.4 \%$ & $10.4 \%$ \\
\hline & UZA 1 million+ & $85.0 \%$ & $80.6 \%$ & $81.4 \%$ & $82.1 \%$ & $83.0 \%$ \\
\hline & Non UZA & $3.5 \%$ & $7.7 \%$ & $3.0 \%$ & $3.0 \%$ & $3.6 \%$ \\
\hline & All & $100.0 \%$ & $100.0 \%$ & $100.0 \%$ & $100.0 \%$ & $100.0 \%$ \\
\hline
\end{tabular}


- Medical Conditions - Persons with medical conditions are an insignificant transit market for work and school purposes, representing 4.7 percent of the transit trips for work purposes and 2.4 percent of the trips for school purposes. However, they represent more than onethird of the transit trips for medical and dental purposes (35.0\%).

- Household Income - The purpose-based transit markets differ significantly in where their ridership comes in terms of households of different income levels, particularly between households in the two extreme ends of the income distribution. Households with income under $\$ 15,000$ make about 20 percent of the transit trips for work and school, respectively, but a significantly higher percentage at 37.7 percent for medical/dental purposes and 34.5 percent for all other purposes. On the other hand, households with income at least $\$ 100,000$ make $18.2-21.2$ percent of transit trips for work and school, respectively but only 4.7 percent for medical/dental purposes and 8.4 percent for all other purposes.

- Vehicle Availability - Households without any vehicles make 25.4 percent of the transit trips for school and 35.4 percent for work purposes. In comparison, they represent almost twothirds of the transit trips for medical/dental purposes (64.1\%) and 59.4 percent for all other purposes. On the other hand, households with inadequate vehicles contribute far more to the transit markets for work and school purposes but little to other purposes. Specifically, they make 26.6-29.7 percent of the transit trips for work and school purposes, but only 6.28.7 percent of the transit trips for medical/dental and other purposes.

- Race and Ethnicity - The pattern of transit use across race and ethnicity groups does not seem to differ much across the transit markets based on trip purpose.

- Frequency of Transit Use - The most frequent users of transit make more than one-half of the transit trips for work purposes (54.5\%). In comparison, they are just 3.0 percent of the total population and make 43.0 percent of all transit trips for all purposes. The least frequent users, on the other hand, make 29.1 percent of the transit trips for medical/dental purposes. In comparison, they make less than 5 percent of the transit trips for work or school purposes.

- Location - The pattern of transit trips across areas with different housing density does not seem to differ much across the markets based on trip purpose.

\subsection{Summary}

This section summarizes the socio-demographics of the transit trip makers in each of the following nine key transit markets used in similar summaries for other sections:

- Non-drivers 
- New immigrants

- Having medical conditions

- Income under $\$ 15,000$

- Zero vehicle Households

- Hispanics

- Non-Hispanic Blacks

- Most frequent users

- Work purposes

The socio-demographics for each of these markets are represented by the distribution of its transit trips across the population segments for each of these socio-demographics. In addition, this section attempts to determine the most important socio-characteristics of a given transit market by comparing the distribution of transit trips for the given transit market (i.e., non-drivers) with the distribution of transit trips for the entire transit market across the same population segments in a graphic form.

For each key transit market, a bar graph is used to display these two distributions. Blue bars and related percent numbers show the distribution of the transit trips taken by a given transit market. Red bars show the distribution of the total transit market. The blue bars indicate the importance of each population segment to a particular transit market. A comparison of the blue bars to the red bars indicates the degree to which any one population segment is over-represented in a given transit market. If the blue bar is shorter than the red bar for a given population segment, this particular population segment is under-represented in the given transit market; otherwise, that population segment is over-represented. Three sets of population segments are categorized in terms of their degree of over-representation in a given transit market:

- Large and Over-Represented - A population segment's share of the given transit market is at least 25 percent and is much greater than its share of the entire transit market. The given transit market is highly likely to have socio-demographics represented by population segments that are large and over-represented.

- Small and Over-Represented - A population segment's share of the given transit market is less than 25 percent but is much greater than its share of the entire transit market. The given transit market is somewhat likely to have socio-demographics represented by population segments that are small and over-represented.

- Under-Represented - A population segment's share of the given transit market is much lower than its share of the entire transit market. The given transit market is much less likely to have socio-demographics represented by population segments that are underrepresented. 


\subsubsection{Non-Drivers}

Figure 5.1 summarizes the socio-demographics of the transit market of non-drivers. More than three-quarters of the transit trips by non-drivers are by any of the following population segments: persons without medical conditions, persons living in urbanized areas with a population at least 1 million, and persons ages 18-64 years. Similarly, 62.5 percent of their transit trips are by those living in census tracts with at least 4,000 housing units per square mile; and 58.1 percent of their trips are by non-immigrants. At the other extreme, under 10 percent of the transit trips by nondrivers are by any of the following population segments: those living in non-urbanized areas or in urbanized areas with a population under 200,000, those living in census tracts with housing density under 1,000 units per square mile, non-Hispanics other than whites and blacks, persons with household income at least $\$ 100,000$, and households with income $\$ 50,000-\$ 99,999$.

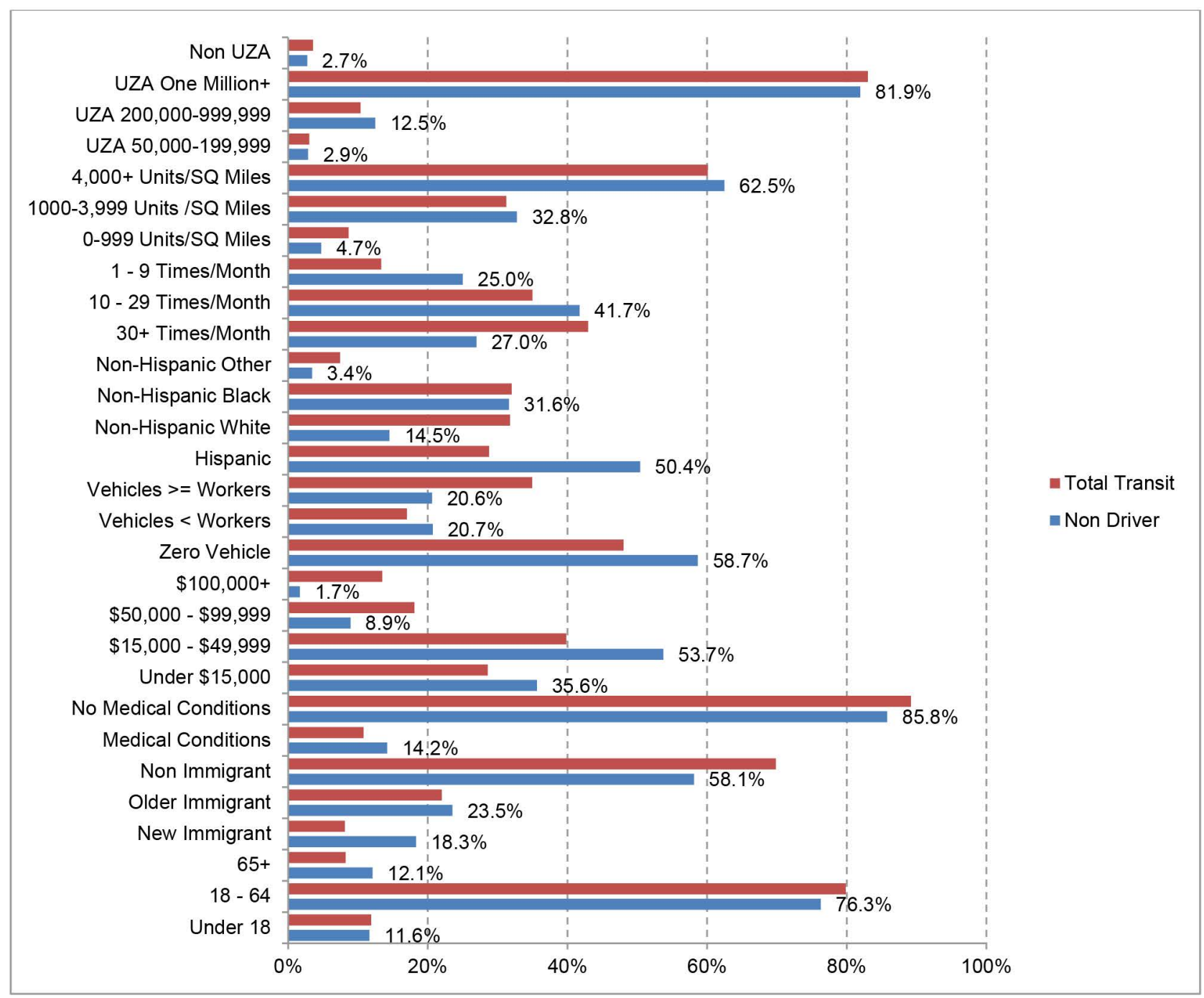

Figure 5.1. Summary of Socio-Demographics of U.S. Non-Drivers 
What is more informative is to know the population segments that make a significantly different share of the transit trips by non-drivers than their share of the entire transit market. These population segments may be grouped into the three categories described earlier:

- Large and Over-Represented - In this category, the degree of over-representation is the highest with the least frequent users of transit, followed by Hispanics, households with income $\$ 15,000-\$ 49,999$, households with income under $\$ 15,000$, households with zero vehicles, and persons with medium frequency of transit use.

- Small and Over-Represented - In this category, the degree of over-representation is the highest with new immigrants, followed by older adults, persons with medical conditions, households with inadequate vehicles, and urbanized areas with a 200,000-999,999 population.

- Under-Represented - The population segments in this category include households in census tracts with housing density under 1,000 units per square mile, the most frequent users of transit, Non-Hispanic Whites, Non-Hispanic Others, and households with income at least $\$ 50,000$. Among these, the degree of under-representation is the highest with households with income at least $\$ 50,000$ and is the lowest is with the most frequent users of transit.

Besides these over- or under-represented population segments, it is interesting to note that older immigrants or Non-Hispanic Blacks capture similar shares of the entire transit market and the transit market of non-drivers. Of particular interest is the population segment of Non-Hispanic Blacks. In many other ways, they behave similarly to Hispanics. For reasons not known, they seem to be quite different from Hispanics in terms of driver status.

\subsubsection{New Immigrants}

Figure 5.2 summarizes the socio-demographics of the transit market of new immigrants. More than 85 percent of the transit trips by new immigrants are by any of the following population segments: persons without medical conditions, persons living in urbanized areas with a population at least 1 million, and persons ages 18-64 years. Similarly, 73.1percent of their transit trips are by drivers, and 61.6 percent are by those living in census tracts with at least 4,000 housing units per square mile. At the other extreme, under 10 percent of the transit trips by new immigrants are by any of the following population segments: persons living in non-urbanized areas or in urbanized areas with a population under 200,000 , persons living in census tracts with housing density under 1,000 units per square mile, persons with household income at least $\$ 100,000$, households with income $\$ 50,000-\$ 99,999$, persons with medical conditions, older adults, and persons under 18 years old. 
It is interesting to examine the population segments that make a significantly different share of the transit trips by new immigrants than their share of the entire transit market. These population segments may be grouped into three categories for discussion:

- Large and Over-Represented - In a declining order of their degree of over-representation, the population segments in this category include non-drivers, Hispanics, households with income under $\$ 15,000$, the most frequent users of transit, and households with income $\$ 15,000-\$ 49,999$.

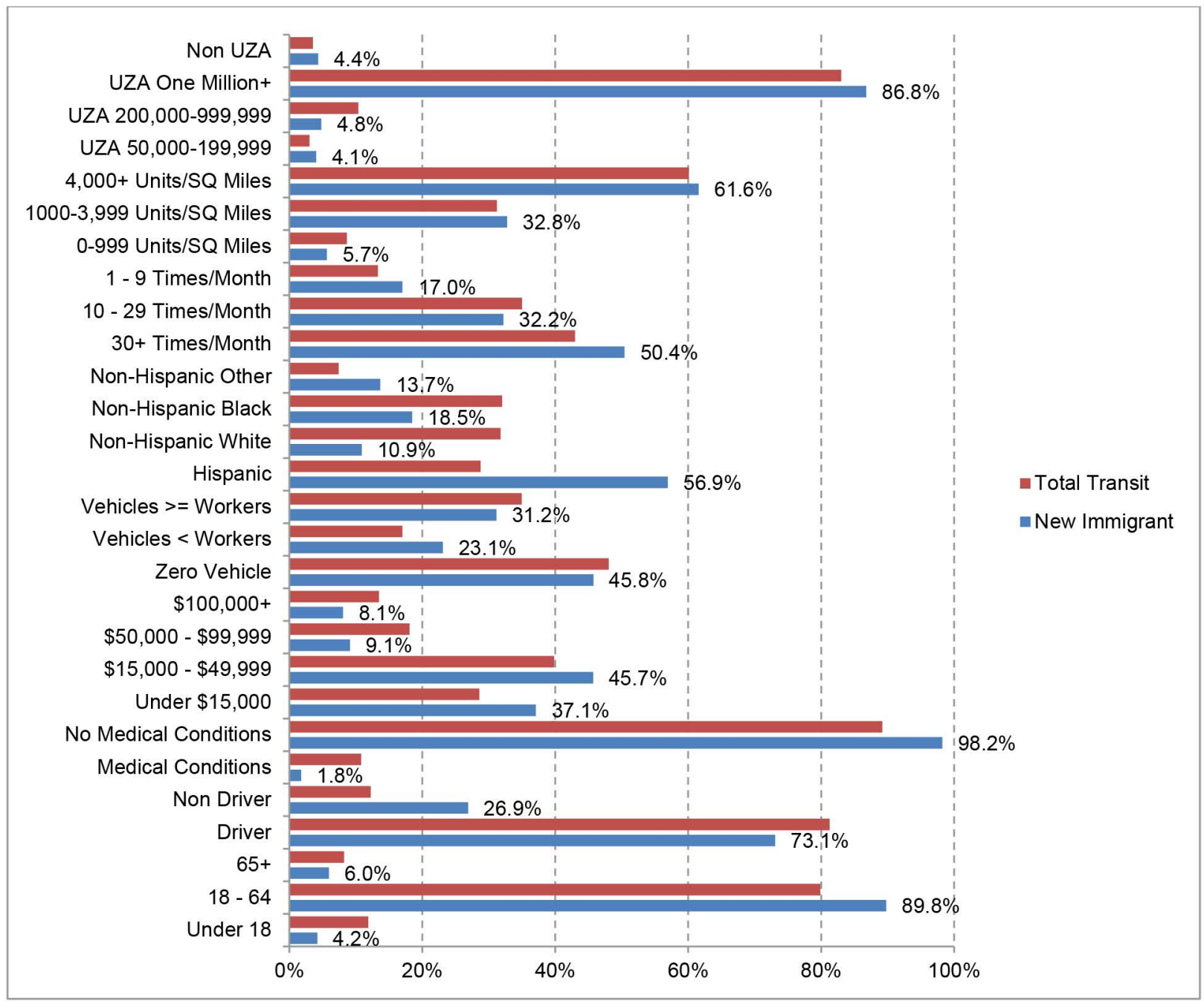

Figure 5.2. Summary of Socio-Demographics of U.S. New Immigrants

- Small and Over-Represented - In a declining order of their degree of over-representation, the population segments in this category include households with inadequate vehicles, the least frequent users of transit, Non-Hispanic Others, and households in urbanized areas with a population under 200,000 . 
- Under-Represented - In a declining order of their degree of under-representation, the population segments in this category include persons with medical conditions, Non-Hispanic Whites, persons under 18 years old, households in urbanized areas with a population 200,000-999,999, households with income at least $\$ 50,000$, Non-Hispanic Blacks, households in census tracts with housing density under 1,000 units per square mile, and older adults.

\subsubsection{Having Medical Conditions}

Figure 5.3 summarizes the socio-demographics of the transit market of persons with medical conditions. More than 70 percent of the transit trips by persons with medical conditions are by any of the following population segments: those living in urbanized areas with a population at least 1 million, households with zero vehicles, non-immigrants, drivers, and those ages 18-64 years. At the other extreme, under 10 percent of the transit trips by persons with medical conditions are by any of the following population segments: those living in non-urbanized areas or in urbanized areas with a population under 200,000 , those living in census tracts with housing density under 1,000 units per square mile, Non-Hispanic Others, households with inadequate vehicles, persons with household income at least $\$ 100,000$, new immigrants, and persons under 18 years old.

It is interesting to examine the population segments that make a significantly different share of the transit trips by persons with medical conditions than their share of the entire transit market. These population segments may be grouped into these three categories:

- Large and Over-Represented - In a declining order of their degree of over-representation, this category includes households with income under $\$ 15,000$, households with zero vehicles, households in census tracts with housing density 1,000-3,999 units per square mile, Non-Hispanic Blacks, and persons with medium frequency of transit use.

- Small and Over-Represented - In a declining order of their degree of over-representation, this category includes older adults, the least frequent users, households in urbanized areas with a population under 1 million, non-urbanized areas, and non-drivers.

- Under-Represented - In a declining order of their degree of under-representation, this category includes households with income at least $\$ 100,000$, new immigrants, households with vehicles, Non-Hispanics Others, households with income $\$ 50,000-\$ 99,999$, households with income $\$ 15,000-\$ 49,999$, and households in census tracts with housing density at least 4,000 units per square mile. 


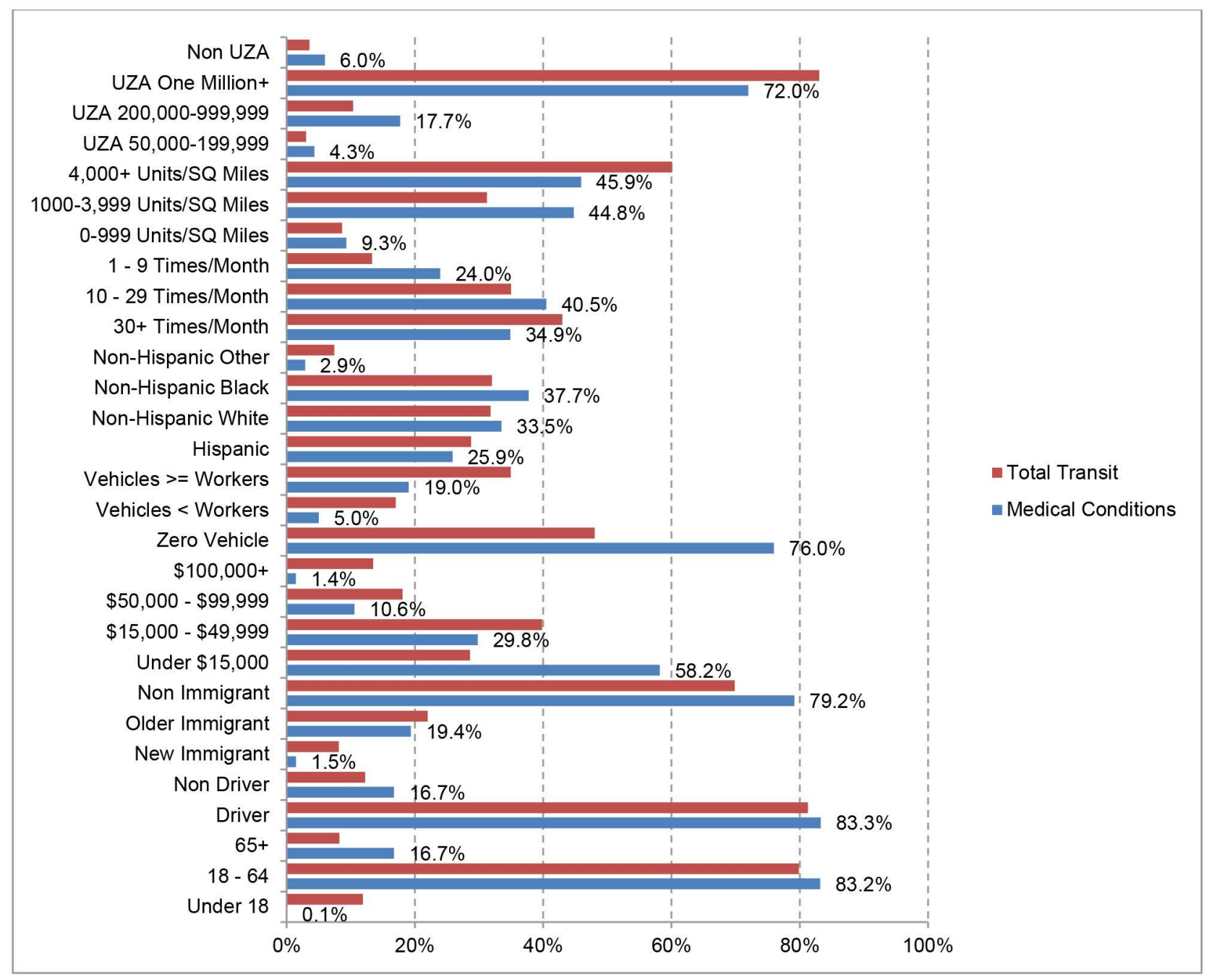

Figure 5.3. Summary of Socio-Demographics of Having Medical Conditions in the U.S.

\subsubsection{Income under $\$ 15,000$}

Figure 5.4 summarizes the socio-demographics of the transit markets of persons with income under $\$ 15,000$. More than two-thirds of the transit trips by low income households are by any of the following population segments: persons without medical conditions, persons living in urbanized areas with a population at least 1 million, persons ages 18-64 years, households without vehicles, non-immigrants, and drivers. At the other extreme, less than 10 percent of the transit trips by low income households are by any of these population segments: persons living in non-urbanized areas or in urbanized areas with a population under 200,000, Non-Hispanic Others, households with inadequate vehicles, and persons under 15 years of age.

It is interesting to examine the population segments that make a significantly different share of the transit trips by low income households than their share of the entire transit market. These population segments may be grouped into these three categories: 
- Large and Over-Represented - In a declining order of their degree of over-representation, the population segments are Non-Hispanic Blacks and households without vehicles.

- Small and Over-Represented - In a declining order of their degree of over-representation, this category includes persons with medical conditions, households in urbanized areas with a population under 1 million, older adults, households in census tracts with housing density under 1,000 units per square mile, the least frequent users, and non-drivers.

- Under-Represented - In a declining order of their under-representation, this category includes Non-Hispanic Others, Non-Hispanic Whites, and households with vehicles.

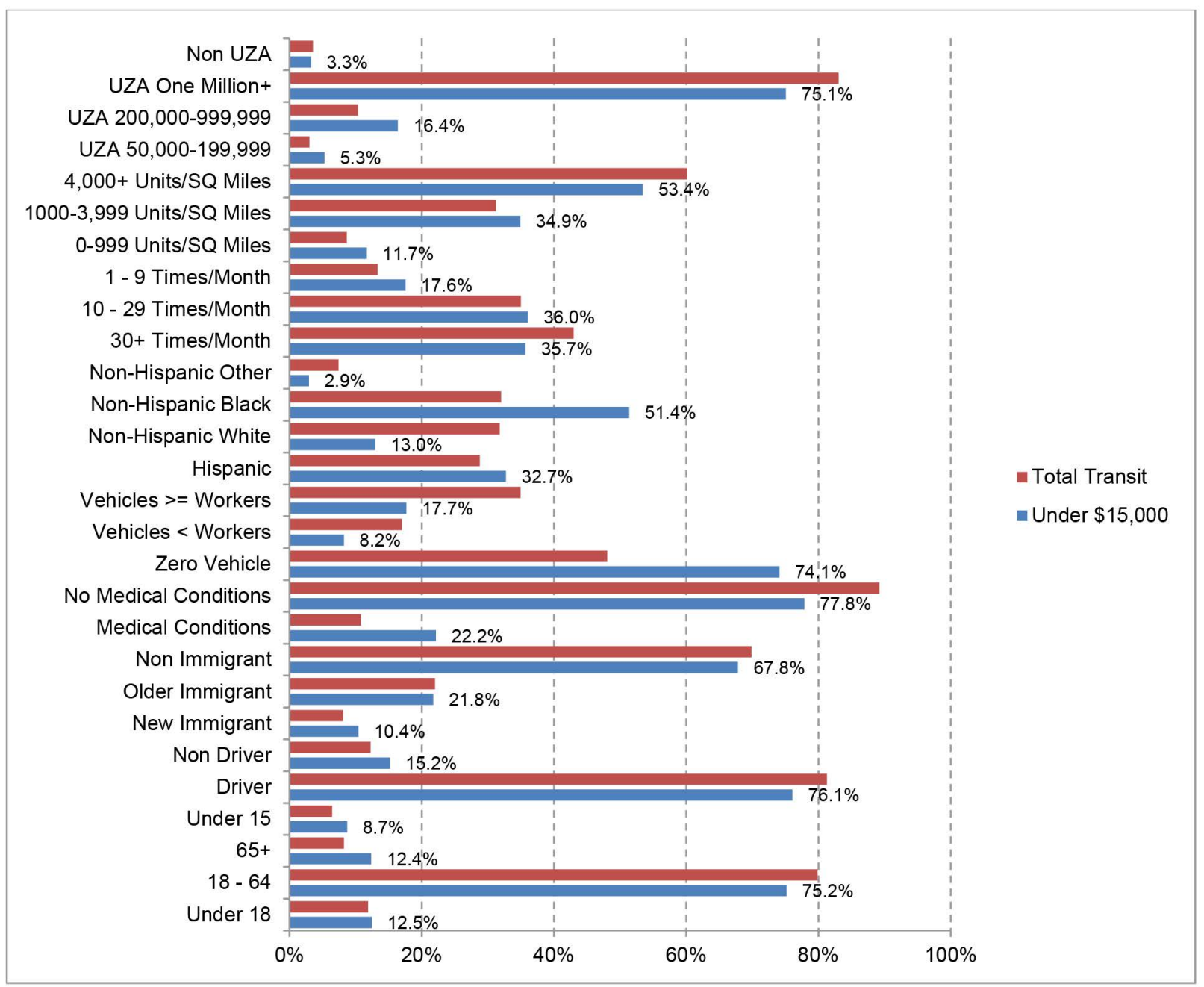

Figure 5.4. Summary of Socio-Demographics of Income under $\$ 15,000$ in the U.S.

\subsubsection{Zero Vehicle Households}

Figure 5.5 summarizes the socio-demographics of the transit market of persons with zero vehicles. More than three-quarters of the transit trips by non-drivers are made by any of the following population segments: persons without medical conditions, persons living in urbanized areas with a 
population at least 1 million, drivers, and persons ages 18-64 years. Similarly, about 70 percent of their transit trips are by those living in census tracts with at least 4,000 housing units per square mile or by non-immigrants. At the other extreme, less than 10 percent of the transit trips by persons without vehicles are taken by any of the following population segments: persons living in nonurbanized areas or in urbanized areas with a population under 200,000 , persons living in census tracts with housing density under 1,000 units per square mile, Non-Hispanics Others, persons with household income at least $\$ 100,000$, new immigrants, and persons under 15 years of age.

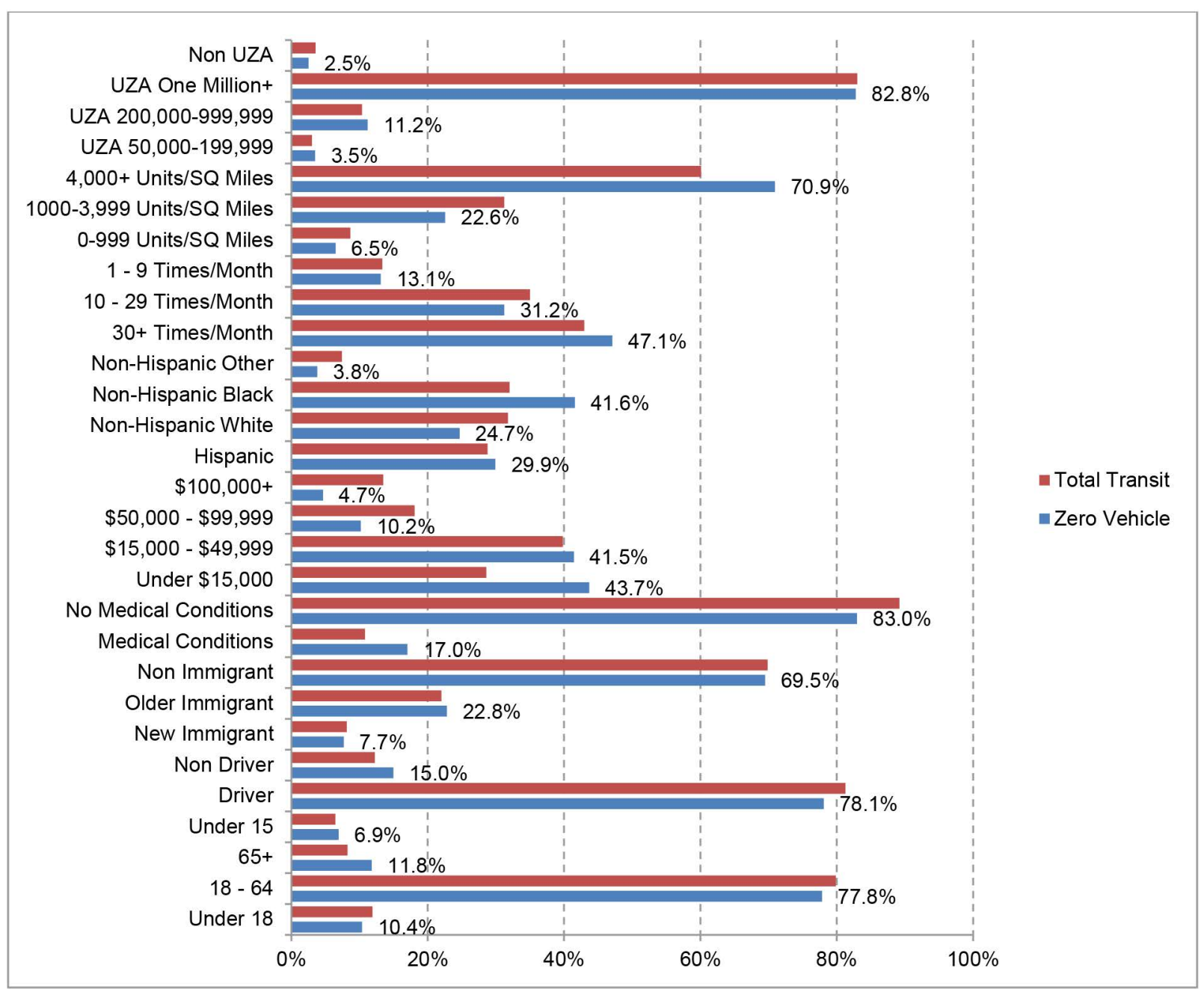

Figure 5.5. Summary of Socio-Demographics of Zero Vehicle Households in the U.S.

It is interesting to examine the population segments that make a significantly different share of the transit trips by persons without vehicles than their share of the entire transit market. These population segments may be grouped into these three categories: 
- Large and Over-Represented - In a declining order of their degree of over-representation, this category includes households with income under $\$ 15,000$, Non-Hispanic Blacks, and households in census tracts with housing density at least 4,000 units per square mile.

- Small and Over-Represented - In a declining order of their degree of over-representation, this category includes persons with medical conditions, older adults, and non-drivers.

- Under-Represented - In a declining order of their degree of under-representation, this category includes households with income at least $\$ 100,000$, Non-Hispanic Others, households with income $\$ 50,000-\$ 99,999$, non-urbanized areas, census tracts with housing density under 4,000 units per square mile, and Non-Hispanic Whites.

\subsubsection{Hispanics}

Figure 5.6 summarizes the socio-demographics of the transit market of Hispanics. More than 80 percent of the transit trips by Hispanics are taken by persons without medical conditions or by persons in urbanized areas with a population at least one million. In addition, 67.4 percent of their transit trips are by those living in census tracts with at least 4,000 housing units per square mile, 67.5 percent of their trips are drivers, and 73.5 percent are by persons 18-64 years old. At the other extreme, less than 10 percent of the transit trips by Hispanics are taken by any of the following population segments: non-urbanized areas, urbanized areas with a population under 200,000 , census tracts with housing density under 1,000 units per square mile, persons with household income at least $\$ 100,000$, and older adults.

It is interesting to examine the population segments that make a significantly different share of the transit trips taken by Hispanics than their share of the entire transit market. These population segments may be grouped into these three categories:

- Large and Over-Represented - In a declining order of their degree of over-representation, these population segments are older immigrants, households with income $\$ 15,000$ $\$ 49,999$, and households with income under $\$ 15,000$.

- Small and Over-Represented - In a declining order of their degree of over-representation, these population segments include new immigrants, non-drivers, persons under 18 years old, and households with inadequate vehicles.

- Under-Represented - In a declining order of their degree of under-representation, these population segments include households with income at least $\$ 100,000$, census tracts with housing density under 1,000 units per square mile, households with income $\$ 50,000$ $\$ 99,999$, and non-immigrants. 


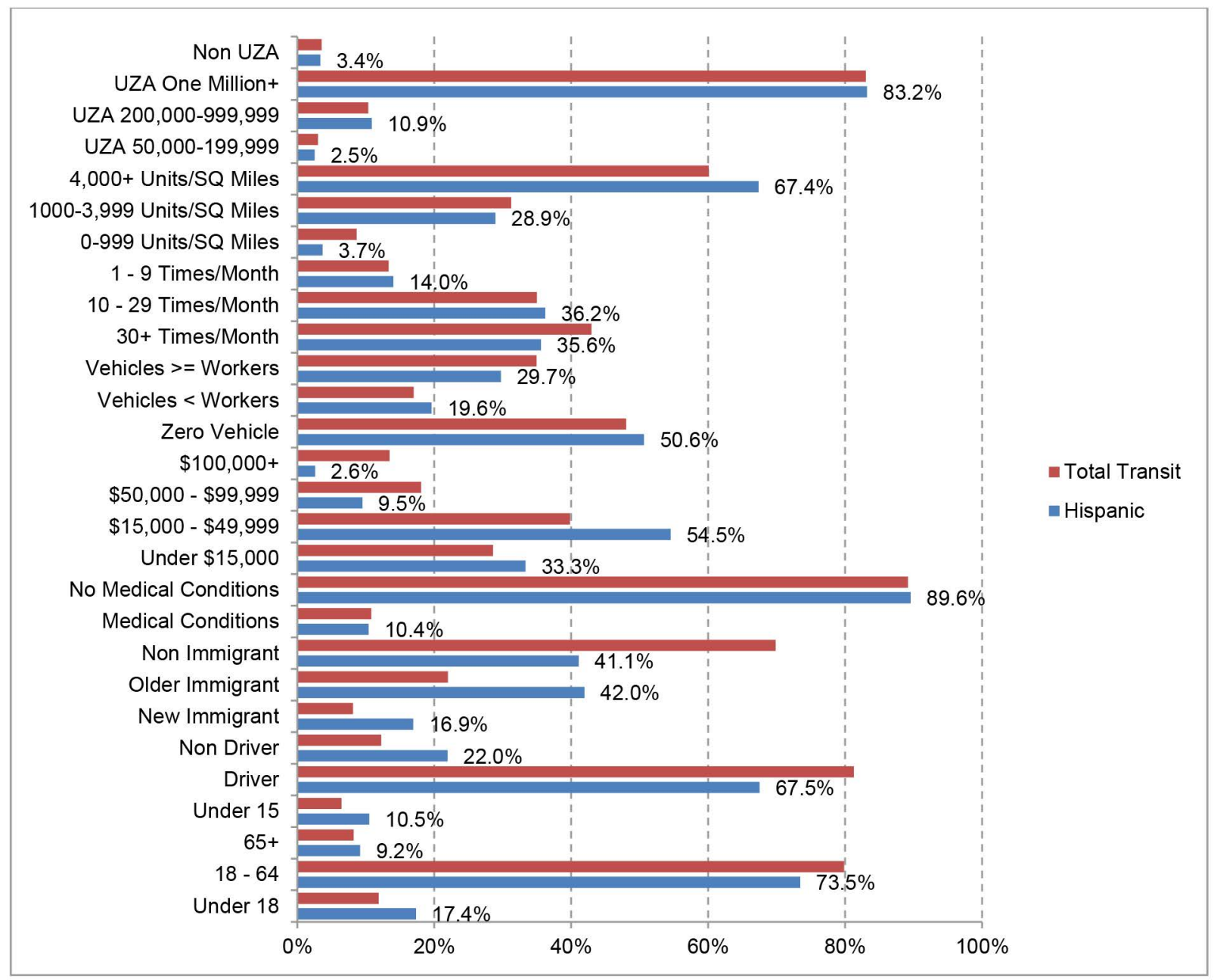

Figure 5.6. Summary of Socio-Demographics of U.S. Hispanics

It is interesting to point out that several large population segments also are seriously underrepresented among Hispanics. Their degree of under-representation is not as large as that for the third category above, but it is still significant. These include drivers and the most frequent users of transit.

\subsubsection{Non-Hispanic Blacks}

Figure 5.7 summarizes the socio-demographics of the transit market of Non-Hispanic Blacks. Over 80 percent of the transit trips by Non-Hispanic Blacks are taken by any of the following segments: urbanized areas with a population at least 1 million, persons without medical conditions, nonimmigrants, drivers, and persons ages 18-64 years. In addition, 62.3 percent of their transit trips are by those living in census tracts with at least 4,000 housing units per square mile; and 63.2 percent of their trips are by households with zero vehicles. At the other extreme, less than 10 percent of the transit trips by Non-Hispanic Blacks are taken by any of these population segments: non-urbanized areas, urbanized areas with a population under 200,000 , census tracts with housing 
density under 1,000 units per square mile, households with income at least $\$ 100,000$, new immigrants, persons under 15 years old, and older adults.

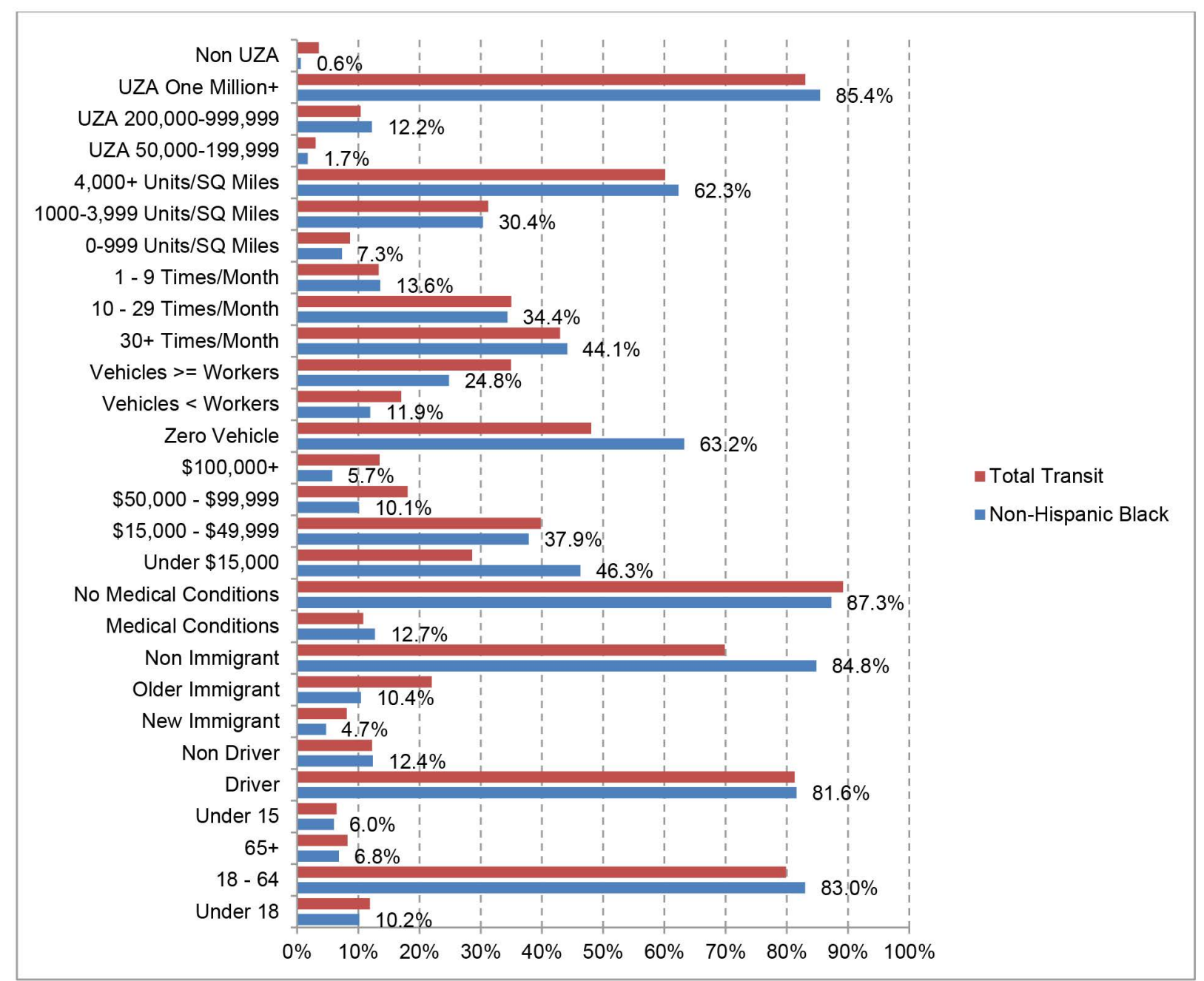

Figure 5.7. Summary of Socio-Demographics of U.S. Non-Hispanic Blacks

It is interesting to examine the population segments that make a significantly different share of the transit trips taken by Non-Hispanic Blacks than their share of the entire transit market. These population segments may be grouped into these three categories:

- Large and Over-Represented - In a declining order of their degree of over-representation, this category includes households with income under $\$ 15,000$, households with zero vehicles, and non-immigrants.

- Small and Over-Represented - In a declining order of their degree of over-representation, this category includes persons with medical conditions and urbanized areas with a population 200,000-999,999. 
- Under-Represented - In a declining order of their degree of under-representation, this category includes non-urbanized areas, households with income at least $\$ 50,000$, older immigrants, urbanized areas with a population under 200,000, new immigrants, and households with vehicles.

\subsubsection{Most Frequent Users of Transit}

Figure 5.8 summarizes the socio-demographics of the transit market of the most frequent users of transit. Around 90 percent of the transit trips taken by the most frequent users are by any of these population segments: persons 18-64 years old, drivers, persons without any medical conditions, and urbanized areas with a population at least 1 million. In addition, about two-thirds of their transit trips are by those living in census tracts with at least 4,000 housing units per square mile, and 66.9 percent of their trips are by non-immigrants. At the other extreme, less than 10 percent of the transit trips by the most frequent users are by any of these population segments: non-urbanized areas, urbanized areas with a population under 200,000 , urbanized areas with a population 200,000-999,999, census tracts with housing density under 1,000 units per square mile, NonHispanics Others, persons with medical conditions, older adults, and persons under 18 years old.

It is interesting to examine the population segments that make a significantly different share of the transit trips by the most frequent users than their share of the entire transit market. These population segments may be grouped into these three categories:

- Large and Over-Represented - In a declining order of their degree of over-representation, this category includes Non-Hispanic Whites, drivers, persons 18-64 years old, and households with zero vehicles.

- Small and Over-Represented - In a declining order of their degree of over-representation, this category includes households with income at least $\$ 100,000$ and households with income $\$ 50,000-\$ 99,999$.

- Under-Represented - In a declining order of their degree of under-representation, this category includes persons under 18 years old, urbanized areas with a population under 200,000 , non-drivers, and older adults.

Besides these over- or under-represented population segments, it is interesting to note that NonHispanic Blacks capture similar shares of the entire transit market and the transit market of the most frequent users. This is similar to some of the other key transit markets, including that of nondrivers. In addition, several large population segments also are seriously under-represented among the most frequent users. Their degree of under-representation is not as large as that for the third category above, but it is still significant. These include households with income under $\$ 15,000$, census tracts with housing density under 4,000 units per square mile, and Hispanics. 


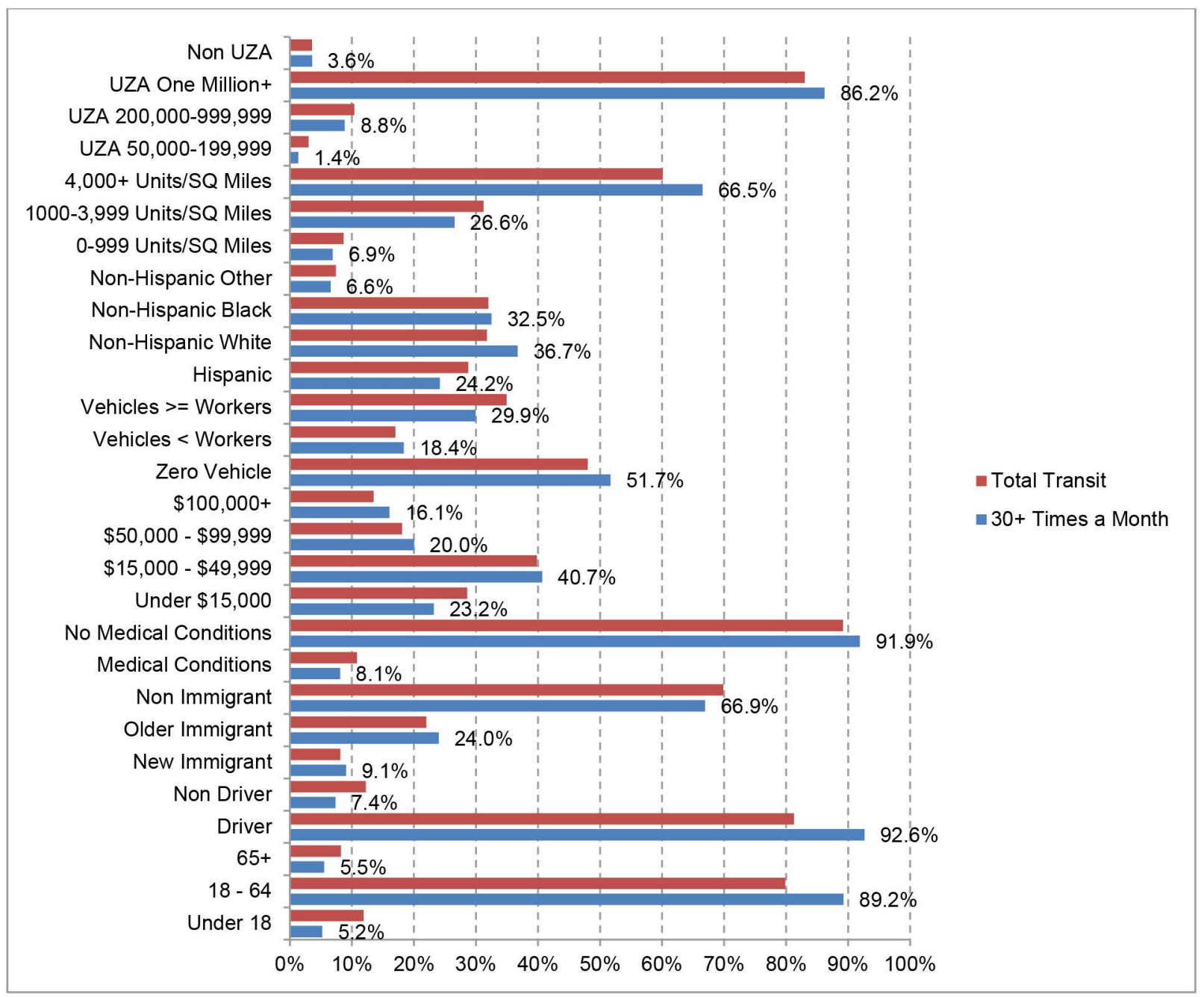

Figure 5.8. Summary of Socio-Demographics of U.S. Most Frequent Users

\subsubsection{Work Purposes}

Figure 5.9 summarizes the socio-demographics of the transit market for work purposes. Well over 90 percent of the transit trips for work purposes are by any of the following population segments: persons without medical conditions, drivers, and persons ages 18-64 years. In addition, 56.1 percent of the transit trips for work are by those living in census tracts with at least 4,000 housing units per square mile, 54.5 percent of work trips are by the most frequent users of transit, and 62.5 percent of the work trips are by non-immigrants. At the other extreme, less than 10 percent of the transit trips for work are by any of the following: non-urbanized areas, urbanized areas with a population under 200,000 , the least frequent users of transit, persons with medical conditions, nondrivers, older adults, and persons under 18 years old. 


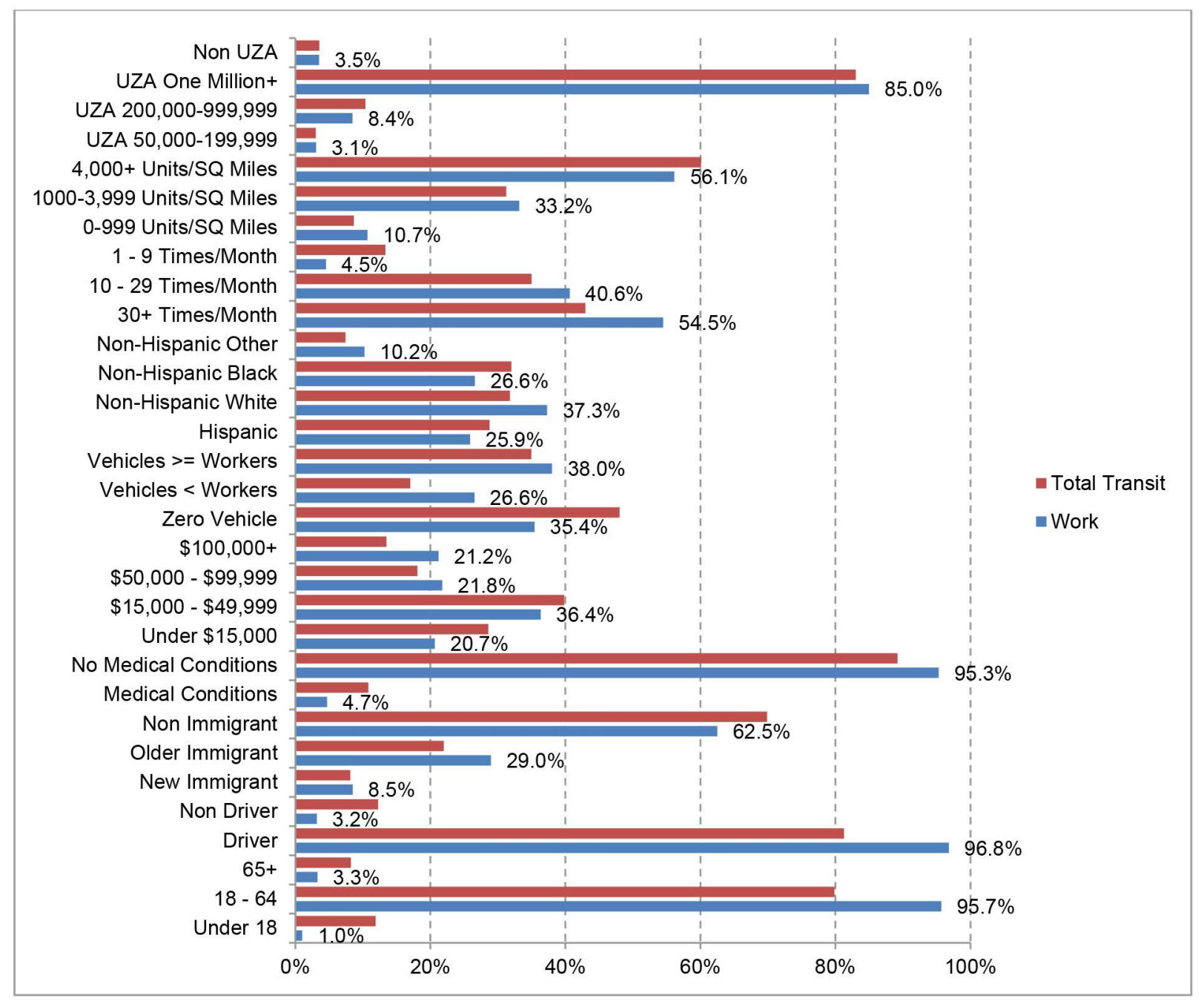

Figure 5.9. Summary of Socio-Demographics of Work Trips for the U.S.

It is interesting to examine the population segments that make a significantly different share of the transit trips for work than their share of the entire transit market. These population segments may be grouped into these three categories:

- Large and Over-Represented - In a declining order of their degree of over-representation, this category includes households with inadequate vehicles, older immigrants, the most frequent users of transit, persons ages 18-64, drivers, and Non-Hispanic Whites.

- Small and Over-Represented - In a declining order of their degree of over-representation, this category includes households with income at least $\$ 100,000$, Non-Hispanic Others, and households with income \$50,000-\$99,999. 
- Under-Represented - In a declining order of their degree of under-representation, this category includes persons under 18 years old, non-drivers, the least frequent users, and persons with medical conditions.

Besides these over- or under-represented population segments, several large population segments also are seriously under-represented in the transit market for work purposes. Their degree of under-representation is not as large as that for the third category above, but it is still significant. These include households with income under $\$ 15,000$, households with zero vehicles, and NonHispanic Blacks. 


\section{TRIP CHARACTERISTICS OF TRANSIT MARKETS}

This section assesses transit markets in terms of the characteristics of their transit trips. Some of these characteristics are specific to transit and others are general to all modes. These characteristics considered include the following:

- Transit-Specific

- Wait time

- Last access mode to the main mode

- First egress mode from the main mode

- Total access time

- Total egress time

- General Characteristics

- Day of week

- Start time

- Purpose

- Distance

- Duration

- Speed

It is critical to note that trip distance, duration, and speed are for entire linked trips rather than for just the transit portions of these linked trips. In addition, the 2009 NHTS collected data on up to five access modes and up to five egress modes for each transit trip. Only the last access mode and first egress mode are presented. Again, the main mode portion of a linked transit trip may involve transfers.

The transit trips are assessed in terms of these trip characteristics for the set of transit markets defined by each of the following characteristics:

- Driver status

- Immigration status

- Medical conditions

- Household income

- Vehicle availability

- Race and ethnicity

- Frequency of transit use

- Trip purpose

Each set of transit markets based on one of these characteristics has its own sub-section. Within each sub-section, the transit-specific characteristics are considered first and followed by the general 
characteristics. The last section summarizes the trip characteristics of some of the transit markets. Just as for the previous sections, this summary focuses on the same nine key transit markets selected from all of the transit markets considered in this report.

\subsection{Driver Status}

\subsubsection{Transit-Specific}

Table 6.1 presents the transit-specific characteristics of transit markets by driver status. Relative to drivers, more non-drivers wait for transit longer and take longer for access and egress. Some 62.3 of the transit trips by non-drivers involve waiting at least 10 minutes, compared to 46.1 percent for drivers. Total access time is at least 10 minutes for 35.9 percent of the transit rips by non-drivers vs. 30.1 percent for drivers. Similarly, total egress time is at least 10 minutes for 42.6 percent of the transit trips by non-drivers, compared to 32.5 percent for drivers. However, the last access mode and the first egress mode are largely similar between drivers and non-drivers.

Table 6.1. Transit-Specific Characteristics of U.S. Transit Markets by Driver Status

\begin{tabular}{|c|c|c|c|c|c|}
\hline \multirow{2}{*}{\multicolumn{2}{|c|}{ Transit-Specific Characteristics }} & \multicolumn{3}{|c|}{ Driver Status } & \multirow[b]{2}{*}{ Total } \\
\hline & & \multirow{5}{*}{$\begin{array}{c}\begin{array}{c}\text { Under } \\
15\end{array} \\
21.1 \% \\
21.1 \% \\
27.6 \% \\
30.2 \%\end{array}$} & \multirow{5}{*}{$\begin{array}{r}\text { Driver } \\
21.9 \% \\
32.0 \% \\
22.1 \% \\
24.0 \%\end{array}$} & \multirow{5}{*}{$\begin{array}{c}\begin{array}{c}\text { Non- } \\
\text { Driver }\end{array} \\
15.6 \% \\
22.1 \% \\
27.9 \% \\
34.4 \%\end{array}$} & \\
\hline \multirow{5}{*}{ Wait time } & Under 5 minutes & & & & $21.1 \%$ \\
\hline & 5 - 9 minutes & & & & $30.1 \%$ \\
\hline & $10-14$ minutes & & & & $23.2 \%$ \\
\hline & $15+$ minutes & & & & $25.7 \%$ \\
\hline & Total & $100.0 \%$ & $100.0 \%$ & $100.0 \%$ & $100.0 \%$ \\
\hline \multirow{6}{*}{$\begin{array}{l}\text { Last access mode } \\
\text { to the main mode }\end{array}$} & Walk & $94.1 \%$ & $89.2 \%$ & $87.3 \%$ & $89.3 \%$ \\
\hline & Transit & $4.0 \%$ & $5.9 \%$ & $8.8 \%$ & $6.1 \%$ \\
\hline & POV & $1.7 \%$ & $3.0 \%$ & $1.1 \%$ & $2.7 \%$ \\
\hline & Bike & -- & $0.8 \%$ & $0.2 \%$ & $0.7 \%$ \\
\hline & Other & $0.1 \%$ & $1.0 \%$ & $2.5 \%$ & $1.1 \%$ \\
\hline & Total & $100.0 \%$ & $100.0 \%$ & $100.0 \%$ & $100.0 \%$ \\
\hline \multirow{6}{*}{$\begin{array}{l}\text { First egress mode } \\
\text { from the main mode }\end{array}$} & Walk & $91.4 \%$ & $86.8 \%$ & $86.4 \%$ & $87.1 \%$ \\
\hline & Transit & $6.8 \%$ & $10.5 \%$ & $10.5 \%$ & $10.2 \%$ \\
\hline & POV & $0.5 \%$ & $1.2 \%$ & $0.9 \%$ & $1.1 \%$ \\
\hline & Bike & -- & $0.7 \%$ & & $0.6 \%$ \\
\hline & Other & $1.3 \%$ & $0.8 \%$ & $2.2 \%$ & $1.0 \%$ \\
\hline & Total & $100.0 \%$ & $100.0 \%$ & $100.0 \%$ & $100.0 \%$ \\
\hline \multirow{5}{*}{ Total access time } & Under 5 minutes & $31.2 \%$ & $35.4 \%$ & $36.1 \%$ & $35.2 \%$ \\
\hline & $5-9$ minutes & $38.6 \%$ & $34.5 \%$ & $28.0 \%$ & $34.0 \%$ \\
\hline & $10-14$ minutes & $17.3 \%$ & $15.3 \%$ & $17.7 \%$ & $15.7 \%$ \\
\hline & $15+$ minutes & $13.0 \%$ & $14.8 \%$ & $18.2 \%$ & $15.1 \%$ \\
\hline & Total & $100.0 \%$ & $100.0 \%$ & $100.0 \%$ & $100.0 \%$ \\
\hline \multirow{5}{*}{ Total egress time } & Under 5 minutes & $26.9 \%$ & $34.7 \%$ & $33.1 \%$ & $34.0 \%$ \\
\hline & 5 - 9 minutes & $37.2 \%$ & $32.8 \%$ & $24.4 \%$ & $32.1 \%$ \\
\hline & 10 - 14 minutes & $16.8 \%$ & $14.5 \%$ & $16.1 \%$ & $14.8 \%$ \\
\hline & $15+$ minutes & $19.1 \%$ & $18.0 \%$ & $26.5 \%$ & $19.1 \%$ \\
\hline & Total & $100.0 \%$ & $100.0 \%$ & $100.0 \%$ & $100.0 \%$ \\
\hline
\end{tabular}




\subsubsection{General}

Table 6.2 presents the general characteristics of transit markets by driver status. Relative to drivers, non-drivers are more likely to use transit at lower speeds during non-peak times for nonwork purposes for trips that are relatively shorter in distance and duration:

- Non-drivers use transit for 18.6 percent of the time on Saturdays and 12.1 percent of the time on Sundays and holidays. For drivers, these percentages are 6.7 percent for Saturdays and 7.5 percent for Sundays and holidays.

Table 6.2. General Characteristics of U.S. Transit Markets by Driver Status

\begin{tabular}{|c|c|c|c|c|c|}
\hline \multirow{2}{*}{\multicolumn{2}{|c|}{ General Characteristics }} & \multicolumn{3}{|c|}{ Driver status } & \multirow[b]{2}{*}{ Total } \\
\hline & & \multirow{2}{*}{$\begin{array}{c}\begin{array}{c}\text { Under } \\
\mathbf{1 5}\end{array} \\
68.8 \% \\
17.6 \% \\
13.6 \% \\
\end{array}$} & \multirow{2}{*}{$\begin{array}{r}\text { Driver } \\
85.8 \% \\
6.7 \% \\
7.5 \%\end{array}$} & \multirow{2}{*}{$\begin{array}{c}\begin{array}{c}\text { Non- } \\
\text { Driver }\end{array} \\
69.3 \% \\
18.6 \% \\
12.1 \%\end{array}$} & \\
\hline \multirow[t]{2}{*}{ Day of week } & $\begin{array}{l}\text { Weekday } \\
\text { Saturday } \\
\text { Sunday \& Holidays }\end{array}$ & & & & $\begin{array}{r}82.7 \% \\
8.8 \% \\
8.5 \%\end{array}$ \\
\hline & Total & $100.0 \%$ & $100.0 \%$ & $100.0 \%$ & $100.0 \%$ \\
\hline \multirow{5}{*}{ Trip start time } & $6 \mathrm{AM}-9 \mathrm{AM}$ & $22.4 \%$ & $23.3 \%$ & $11.7 \%$ & $21.8 \%$ \\
\hline & Midday & $41.8 \%$ & $34.6 \%$ & $49.2 \%$ & $36.8 \%$ \\
\hline & 3 PM - 6 PM & $24.2 \%$ & $24.6 \%$ & $15.9 \%$ & $23.5 \%$ \\
\hline & Night & $11.6 \%$ & $17.5 \%$ & $23.2 \%$ & $17.8 \%$ \\
\hline & Total & $100.0 \%$ & $100.0 \%$ & $100.0 \%$ & $100.0 \%$ \\
\hline \multirow{5}{*}{ Trip purpose } & Work \& work related & -- & $43.1 \%$ & $9.7 \%$ & $36.3 \%$ \\
\hline & School & $27.6 \%$ & $7.3 \%$ & $10.1 \%$ & $8.9 \%$ \\
\hline & Medical \& dental & $6.7 \%$ & $4.8 \%$ & $11.8 \%$ & $5.7 \%$ \\
\hline & Other & $65.7 \%$ & $44.9 \%$ & $68.4 \%$ & $49.0 \%$ \\
\hline & Total & $100.0 \%$ & $100.0 \%$ & $100.0 \%$ & $100.0 \%$ \\
\hline \multirow{8}{*}{ Total distance } & Under 1 mile & $14.4 \%$ & $7.9 \%$ & $8.4 \%$ & $8.4 \%$ \\
\hline & 1 - under 2 miles & $16.4 \%$ & $9.8 \%$ & $15.0 \%$ & $10.9 \%$ \\
\hline & 2 - under 3 miles & $20.2 \%$ & $12.6 \%$ & $15.9 \%$ & $13.5 \%$ \\
\hline & 3 - under 5 miles & $20.8 \%$ & $15.1 \%$ & $28.9 \%$ & $17.1 \%$ \\
\hline & 5 - under 10 miles & $16.9 \%$ & $24.7 \%$ & $18.4 \%$ & $23.4 \%$ \\
\hline & 10 - under 15 miles & $5.0 \%$ & $12.9 \%$ & $4.3 \%$ & $11.4 \%$ \\
\hline & $15+$ miles & $6.3 \%$ & $17.0 \%$ & $9.0 \%$ & $15.3 \%$ \\
\hline & Total & $100.0 \%$ & $100.0 \%$ & $100.0 \%$ & $100.0 \%$ \\
\hline \multirow{7}{*}{ Total duration } & Under 15 minutes & $5.1 \%$ & $5.9 \%$ & $5.4 \%$ & $5.8 \%$ \\
\hline & $15-29$ minutes & $19.7 \%$ & $19.2 \%$ & $20.9 \%$ & $19.4 \%$ \\
\hline & $30-44$ minutes & $33.0 \%$ & $25.2 \%$ & $30.2 \%$ & $26.3 \%$ \\
\hline & $45-59$ minutes & $15.2 \%$ & $15.4 \%$ & $13.0 \%$ & $15.1 \%$ \\
\hline & 45 - 59 minutes & $13.5 \%$ & $16.1 \%$ & $15.4 \%$ & $15.9 \%$ \\
\hline & $60+$ minutes & $13.6 \%$ & $18.1 \%$ & $15.1 \%$ & $17.4 \%$ \\
\hline & Total & $100.0 \%$ & $100.0 \%$ & $100.0 \%$ & $100.0 \%$ \\
\hline \multirow{7}{*}{ Speed } & Under $3 \mathrm{mph}$ & $29.3 \%$ & $13.9 \%$ & $16.4 \%$ & $15.2 \%$ \\
\hline & 3 - under $5 \mathrm{mph}$ & $27.2 \%$ & $15.3 \%$ & $31.7 \%$ & $18.0 \%$ \\
\hline & 5 - under $10 \mathrm{mph}$ & $25.7 \%$ & $30.4 \%$ & $29.6 \%$ & $30.0 \%$ \\
\hline & 10 - under $15 \mathrm{mph}$ & $10.4 \%$ & $18.2 \%$ & $8.3 \%$ & $16.5 \%$ \\
\hline & 15 to under $25 \mathrm{mph}$ & $3.9 \%$ & $13.6 \%$ & $11.2 \%$ & $12.8 \%$ \\
\hline & $25+\mathrm{mph}$ & $3.5 \%$ & $8.5 \%$ & $2.7 \%$ & $7.5 \%$ \\
\hline & Total & $100.0 \%$ & $100.0 \%$ & $100.0 \%$ & $100.0 \%$ \\
\hline
\end{tabular}


- Non-drivers use transit for 49.2 percent of the time during midday and for 23.2 percent of the time at night. For drivers, these percentages are 34.6 percent for midday and 17.5 percent for night.

- Non-drivers use transit for work only for one-tenth of the time (9.7\%) vs. 43.1 percent by drivers. They use transit for 11.8 percent of the time for medical/dental purposes (relative to $4.8 \%$ by drivers) and for 68.4 percent of the time for other purposes (relative to $44.9 \%$ by drivers).

- A total of 68.2 percent of the transit trips by non-drivers are shorter than 5 miles versus 45.4 percent for drivers. A total of 56.5 percent of the transit trips by non-drivers last fewer than 45 minutes, vs. 50.3 percent for drivers. A total of 48.1 percent of the transit trips by nondrivers are slow at speeds under $5 \mathrm{mph}$, vs. 29.2 percent for drivers.

\subsection{Immigration Status}

\subsubsection{Transit-Specific}

Table 6.3 presents results on the transit-specific characteristics of transit markets by immigrant status. The choice of the last access mode and the first egress mode is similar across the immigration-based transit markets. However, immigrants experience a smaller share of their transit trips with wait time under 5 minutes: 14.9 percent for new immigrants, 15.8 percent for older immigrants, and 23.8 percent for non-immigrants. On the other hand, fewer new immigrants take under 5 minutes for access than both older immigrants and non-immigrants.

\subsubsection{General}

Table 6.4 presents results on the general characteristics of transit markets by immigration status. New immigrants are slightly more likely to use transit on Sundays and holidays, but less likely to use it on Saturdays. New immigrants make 13.2 percent of their transit trips on Sundays or holidays, compared to 11.0 percent for old immigrants and 7.3 percent for non-immigrants. Both immigrant markets make about 6 percent of their transit trips on Saturdays, vs. about 10 percent by non-immigrants. In addition, immigrants are twice as likely to use transit on Sundays and holidays as on Saturdays, but non-immigrants are more likely to use transit on Saturdays than on Sundays and holidays.

Immigrants are more likely to use transit for work purposes, particularly older immigrants. About one-third of the transit trips by non-immigrants are for work purposes. In comparison, 37.4 percent of the transit rips by new immigrants are for work purposes and 47.7 percent of the trips by older immigrants are for work purposes. Immigrants and non-immigrants are similar in the daily timing of their transit trips. No particular patterns are observed in trip distance, duration, or speed between immigrants and non-immigrants. 
Table 6.3. Transit-Specific Characteristics of U.S. Transit Markets by Immigration Status

\begin{tabular}{|c|c|c|c|c|c|}
\hline \multirow{2}{*}{\multicolumn{2}{|c|}{ Transit-Specific Characteristics }} & \multicolumn{3}{|c|}{ Immigration Status } & \multirow[b]{2}{*}{ Total } \\
\hline & & \multirow{2}{*}{$\begin{array}{r}\begin{array}{c}\text { New } \\
\text { Immigrant }\end{array} \\
14.9 \% \\
31.7 \% \\
24.7 \% \\
28.6 \%\end{array}$} & \multirow{2}{*}{$\begin{array}{c}\begin{array}{c}\text { Older } \\
\text { Immigrant }\end{array} \\
15.8 \% \\
32.2 \% \\
23.1 \% \\
28.8 \%\end{array}$} & \multirow{2}{*}{$\begin{array}{r}\begin{array}{c}\text { Non- } \\
\text { Immigrant }\end{array} \\
23.8 \% \\
29.1 \% \\
22.6 \% \\
24.5 \%\end{array}$} & \\
\hline Wait time & $\begin{array}{l}\text { Under } 5 \text { minutes } \\
5-9 \text { minutes } \\
10-14 \text { minutes } \\
15+\text { minutes }\end{array}$ & & & & $\begin{array}{l}21.1 \% \\
30.1 \% \\
23.2 \% \\
25.7 \%\end{array}$ \\
\hline & Total & $100.0 \%$ & $100.0 \%$ & $100.0 \%$ & $100.0 \%$ \\
\hline \multirow[t]{2}{*}{$\begin{array}{l}\text { Last access } \\
\text { mode to the main } \\
\text { mode }\end{array}$} & $\begin{array}{l}\text { Walk } \\
\text { Transit } \\
\text { POV } \\
\text { Bike } \\
\text { Other } \\
\end{array}$ & $\begin{array}{r}91.1 \% \\
5.8 \% \\
1.8 \% \\
0.9 \% \\
0.4 \% \\
\end{array}$ & $\begin{array}{r}89.7 \% \\
6.6 \% \\
2.6 \% \\
0.6 \% \\
0.5 \% \\
\end{array}$ & $\begin{array}{r}89.4 \% \\
5.6 \% \\
2.9 \% \\
0.6 \% \\
1.4 \% \\
\end{array}$ & $\begin{array}{r}89.3 \% \\
6.1 \% \\
2.7 \% \\
0.7 \% \\
1.1 \% \\
\end{array}$ \\
\hline & Total & $100.0 \%$ & $100.0 \%$ & $100.0 \%$ & $100.0 \%$ \\
\hline \multirow[t]{2}{*}{$\begin{array}{l}\text { First egress } \\
\text { mode from the } \\
\text { main mode }\end{array}$} & $\begin{array}{l}\text { Walk } \\
\text { Transit } \\
\text { POV } \\
\text { Bike } \\
\text { Other }\end{array}$ & $\begin{array}{r}88.0 \% \\
10.7 \% \\
0.4 \% \\
0.6 \% \\
0.3 \%\end{array}$ & $\begin{array}{r}88.1 \% \\
9.6 \% \\
1.0 \% \\
0.7 \% \\
0.7 \%\end{array}$ & $\begin{array}{r}87.0 \% \\
10.1 \% \\
1.3 \% \\
0.5 \% \\
1.1 \%\end{array}$ & $\begin{array}{r}87.1 \% \\
10.2 \% \\
1.1 \% \\
0.6 \% \\
1.0 \%\end{array}$ \\
\hline & Total & $100.0 \%$ & $100.0 \%$ & $100.0 \%$ & $100.0 \%$ \\
\hline \multirow[t]{2}{*}{ Total access time } & $\begin{array}{l}\text { Under } 5 \text { minutes } \\
5-9 \text { minutes } \\
10-14 \text { minutes } \\
15+\text { minutes }\end{array}$ & $\begin{array}{l}29.3 \% \\
32.5 \% \\
24.0 \% \\
14.3 \%\end{array}$ & $\begin{array}{l}35.1 \% \\
32.6 \% \\
15.7 \% \\
16.6 \%\end{array}$ & $\begin{array}{l}36.4 \% \\
34.6 \% \\
14.8 \% \\
14.2 \%\end{array}$ & $\begin{array}{l}35.2 \% \\
34.0 \% \\
15.7 \% \\
15.1 \%\end{array}$ \\
\hline & Total & $100.0 \%$ & $100.0 \%$ & $100.0 \%$ & $100.0 \%$ \\
\hline \multirow[t]{2}{*}{ Total egress time } & $\begin{array}{l}\text { Under } 5 \text { minutes } \\
5 \text { - } 9 \text { minutes } \\
10-14 \text { minutes } \\
15+\text { minutes }\end{array}$ & $\begin{array}{l}25.5 \% \\
34.1 \% \\
20.6 \% \\
19.7 \% \\
\end{array}$ & $\begin{array}{l}31.3 \% \\
31.8 \% \\
15.5 \% \\
21.4 \% \\
\end{array}$ & $\begin{array}{l}36.0 \% \\
32.0 \% \\
14.0 \% \\
18.1 \% \\
\end{array}$ & $\begin{array}{l}34.0 \% \\
32.1 \% \\
14.8 \% \\
19.1 \% \\
\end{array}$ \\
\hline & Total & $100.0 \%$ & $100.0 \%$ & $100.0 \%$ & $100.0 \%$ \\
\hline
\end{tabular}


Table 6.4. General Characteristics of U.S. Transit Markets by Immigration Status

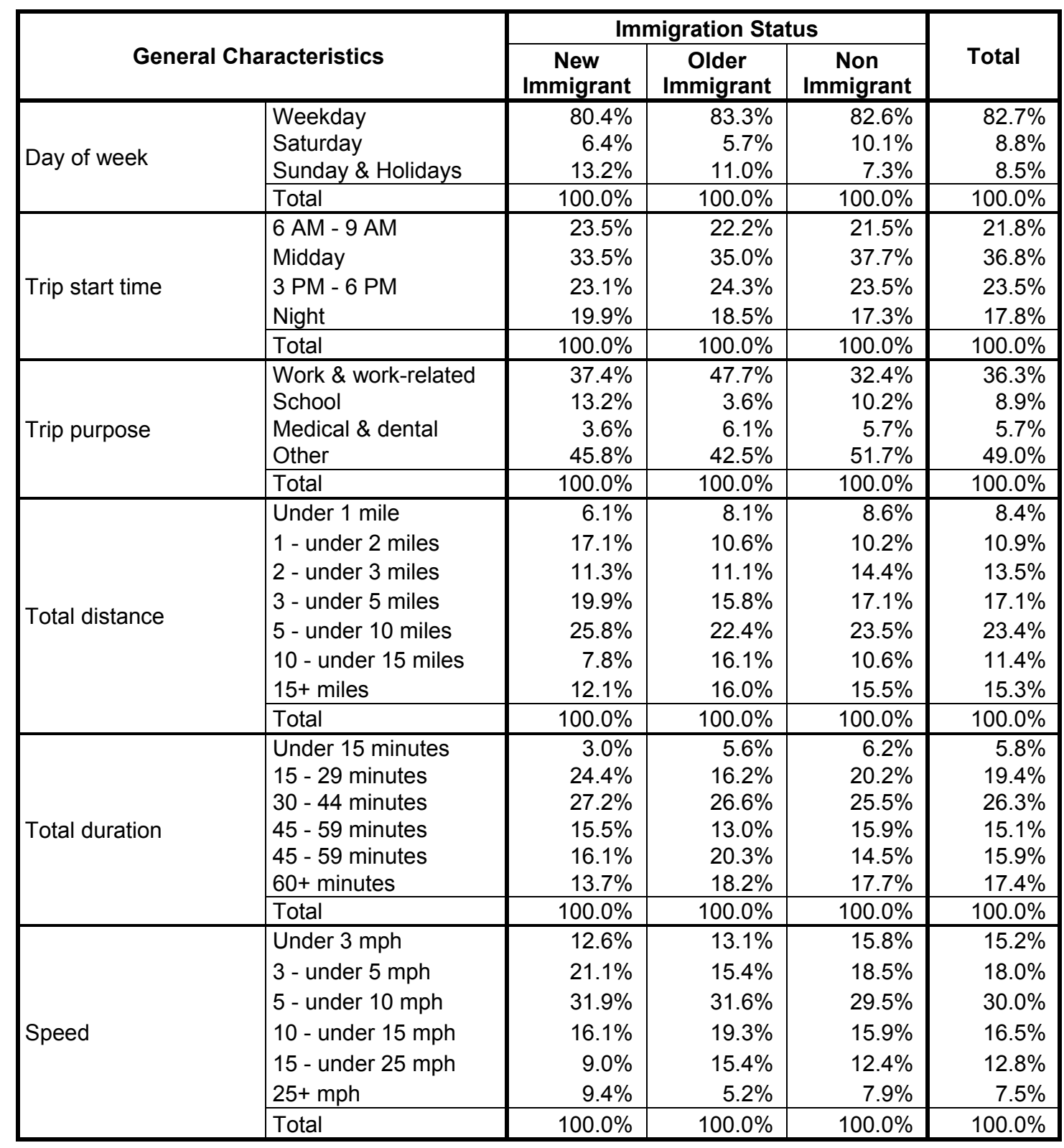




\subsection{Medical Conditions}

\subsubsection{Transit-Specific}

Table 6.5 shows results on the transit-specific characteristics of transit markets by medical conditions.

Table 6.5. Transit-Specific Characteristics of U.S. Transit Markets by Medical Conditions

\begin{tabular}{|c|c|c|c|c|}
\hline \multirow{2}{*}{\multicolumn{2}{|c|}{ Transit-Specific Characteristics }} & \multicolumn{2}{|c|}{ Existence of Medical Conditions } & \multirow[b]{2}{*}{ Total } \\
\hline & & $\begin{array}{l}\text { Having Medical } \\
\text { Conditions } \\
\end{array}$ & $\begin{array}{l}\text { No Medical } \\
\text { Conditions }\end{array}$ & \\
\hline \multirow[t]{2}{*}{ Wait time } & $\begin{array}{l}\text { Under } 5 \text { minutes } \\
5 \text { to } 9 \text { minutes } \\
10 \text { to } 14 \text { minutes } \\
15+\text { minutes }\end{array}$ & $\begin{array}{r}13.4 \% \\
17.5 \% \\
24.7 \% \\
44.4 \%\end{array}$ & $\begin{array}{l}22.0 \% \\
32.4 \% \\
22.7 \% \\
22.9 \%\end{array}$ & $\begin{array}{l}21.1 \% \\
30.1 \% \\
23.2 \% \\
25.7 \%\end{array}$ \\
\hline & Total & $100.0 \%$ & $100.0 \%$ & $100.0 \%$ \\
\hline \multirow{6}{*}{$\begin{array}{l}\text { Last access mode to } \\
\text { the main mode }\end{array}$} & Walk & $91.5 \%$ & $88.6 \%$ & $89.3 \%$ \\
\hline & Transit & $4.8 \%$ & $6.5 \%$ & $6.1 \%$ \\
\hline & POV & $0.8 \%$ & $3.0 \%$ & $2.7 \%$ \\
\hline & Bike & $0.5 \%$ & $0.8 \%$ & $0.7 \%$ \\
\hline & Other & $2.4 \%$ & $1.1 \%$ & $1.1 \%$ \\
\hline & Total & $100.0 \%$ & $100.0 \%$ & $100.0 \%$ \\
\hline \multirow{6}{*}{$\begin{array}{l}\text { First egress mode } \\
\text { from the main mode }\end{array}$} & Walk & $88.5 \%$ & $86.5 \%$ & $87.1 \%$ \\
\hline & Transit & $7.5 \%$ & $10.9 \%$ & $10.2 \%$ \\
\hline & POV & $1.6 \%$ & $1.1 \%$ & $1.1 \%$ \\
\hline & Bike & $0.4 \%$ & $0.7 \%$ & $0.6 \%$ \\
\hline & Other & $2.0 \%$ & $0.9 \%$ & $1.0 \%$ \\
\hline & Total & $100.0 \%$ & $100.0 \%$ & $100.0 \%$ \\
\hline \multirow{5}{*}{ Total access time } & Under 5 minutes & $32.6 \%$ & $35.7 \%$ & $35.2 \%$ \\
\hline & 5 - 9 minutes & $31.4 \%$ & $34.0 \%$ & $34.0 \%$ \\
\hline & $10-14$ minutes & $14.7 \%$ & $15.7 \%$ & $15.7 \%$ \\
\hline & $15+$ minutes & $21.3 \%$ & $14.6 \%$ & $15.1 \%$ \\
\hline & Total & $100.0 \%$ & $100.0 \%$ & $100.0 \%$ \\
\hline \multirow{5}{*}{ Total egress time } & Under 5 minutes & $30.0 \%$ & $34.9 \%$ & $34.0 \%$ \\
\hline & 5 - 9 minutes & $28.1 \%$ & $32.3 \%$ & $32.1 \%$ \\
\hline & $10-14$ minutes & $17.6 \%$ & $14.3 \%$ & $14.8 \%$ \\
\hline & $15+$ minutes & $24.3 \%$ & $18.4 \%$ & $19.1 \%$ \\
\hline & Total & $100.0 \%$ & $100.0 \%$ & $100.0 \%$ \\
\hline
\end{tabular}

Persons with medical conditions are twice as likely as persons without medical conditions to wait for transit for at least 15 minutes (44.4\% vs. $22.9 \%$ ). Persons with medical conditions also are more likely than persons without medical conditions to take at least 15 minutes for access $(21.3 \%$ vs. $14.6 \%)$ and egress (24.3\% vs. $18.4 \%$ ). Persons with medical conditions are less likely to use transit for access to or egress from the main mode.

\subsubsection{General}

Table 6.6 presents results on the general characteristics of transit markets by medical conditions. 
Table 6.6. General Characteristics of U.S. Transit Markets by Medical Conditions

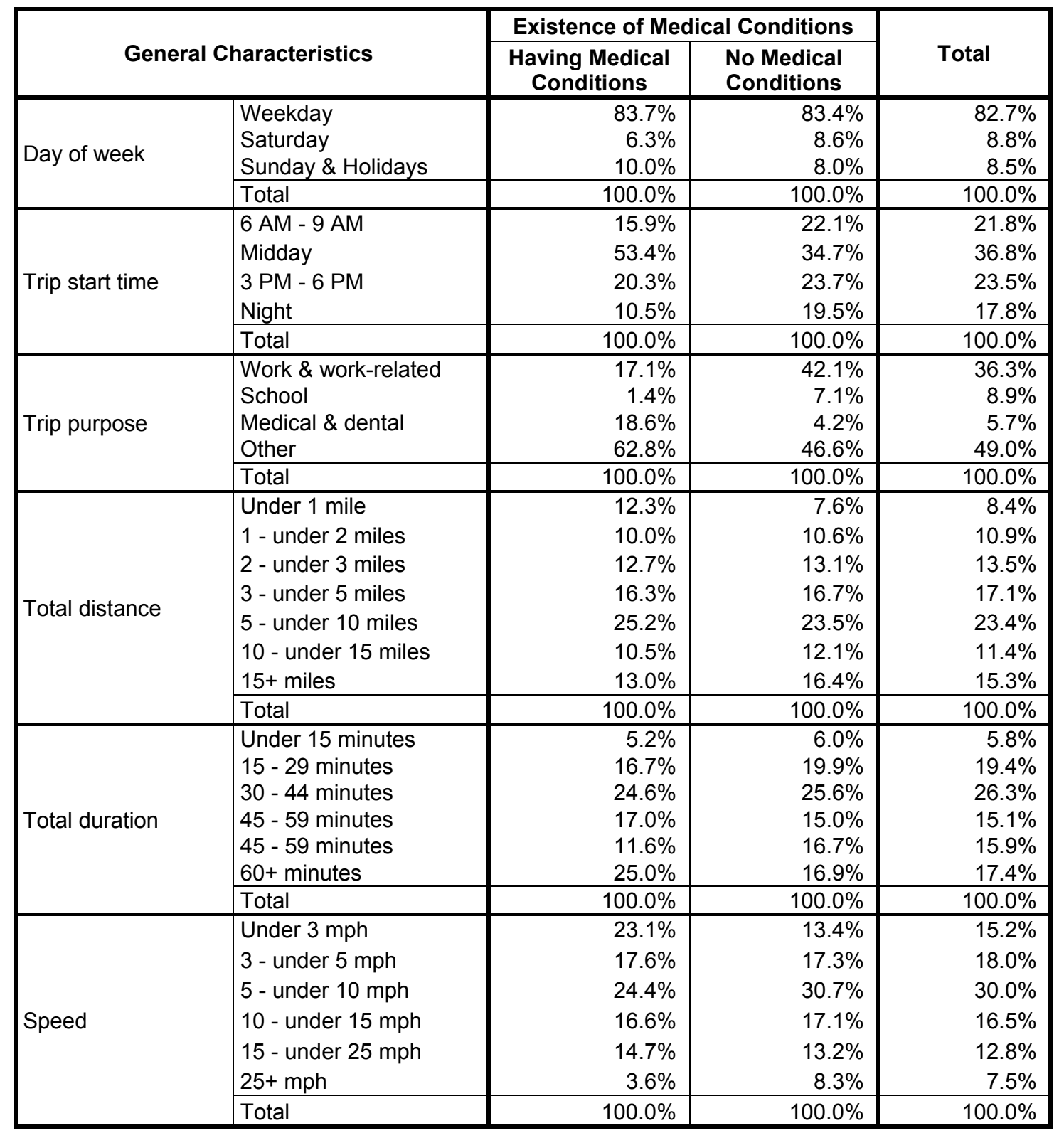

Persons with medical conditions are as likely as persons without medical conditions to use transit on weekdays. However, they are somewhat less likely than persons without medical conditions to use transit on Saturdays (6.3\% vs. $8.6 \%$ ) but somewhat more likely to use it on Sundays and holidays (10.0\% vs. $8.0 \%$ ). Persons with medical conditions are significantly more likely than persons without medical conditions to use transit during midday (53.4\% vs. $34.7 \%)$. But they are less likely to use transit during other periods, particularly during AM peak (15.9\% vs. $22.1 \%)$ and at night $(10.5 \%$ vs. $19.5 \%)$. 
Persons with medical conditions are significantly less likely than persons without medical conditions to use transit for work purposes (17.1\% vs. $42.1 \%)$. But they are far more likely to use transit for medical and dental purposes (18.6\% vs. $4.2 \%$ ) and for other purposes (62.8\% vs. $46.6 \%)$.

Persons with medical conditions are more likely than persons without medical conditions to use transit for trips under 1 mile long (12.3\% vs. $7.6 \%)$ but are less likely to use transit for trips at least 10 miles long (23.5\% vs. $28.5 \%$ ). In addition, more of the transit trips by persons with medical conditions have speeds under $3 \mathrm{mph}(23.1 \%$ vs. $13.4 \%)$ and last at least one hour $(25.0 \%$ vs. $16.9 \%)$.

\subsection{Household Income}

\subsubsection{Transit-Specific}

Table 6.7 has results on the transit-specific characteristics of transit markets by household income.

Table 6.7. Transit-Specific Characteristics of U.S. Transit Markets by Household Income

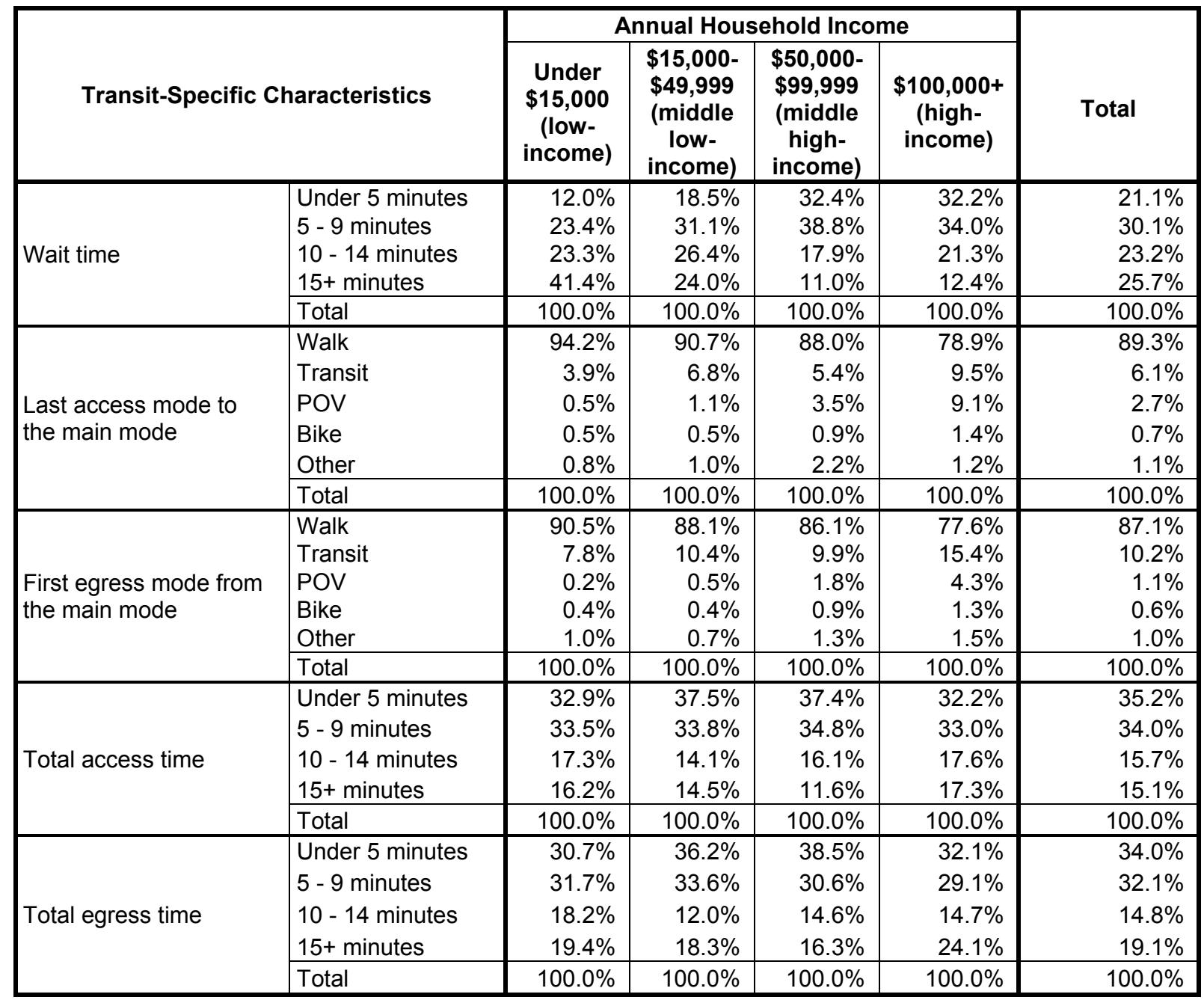


Persons with lower income appear to experience more waiting than persons with higher income. The transit trips by persons with income under $\$ 15,000$ are far less likely than persons with income at least $\$ 50,000$ to wait for less than 5 minutes $(12.0 \%$ vs. about $32.0 \%)$. On the other hand, wait time is at least 15 minutes for 41.4 percent of the transit trips by persons with income under $\$ 15,000$, but for $11.0-12.4$ percent for persons with income at least $\$ 50,000$. There are several possible reasons for these differences in wait time across these markets. One is that the level of service actually does differ across the different income-based transit markets in terms of geographic areas. Another possible reason is that the level of service differs across the markets not because of geographical reasons but because of the type of service used (e.g., peak vs. off-peak). A third possible reason is that persons with higher household income may be able to time their arrival at transit stops and stations better than persons with lower household income.

Persons with higher income are less likely to walk but are more likely to use other major modes as the last access mode or the first egress mode. For access:

- The share of walk access is 94.2 percent for persons with income under $\$ 15,000$ but only 78.9 percent for persons with income at least $\$ 100,000$.

- $\quad$ The share of transit access is 3.9 percent for persons with income under $\$ 15,000$ but 9.5 percent for persons with income at least $\$ 100,000$.

- The share of POV access is only 0.5 percent for persons with income under $\$ 15,000$ but 9.1 percent for persons with persons with income at least $\$ 100,000$.

For egress:

- Walking is used as the first egress mode for 90.5 of the trips for the low-income market, 88.1 percent of the trips for the middle low-income market, 86.1 percent for the middle highincome market, and 77.6 percent for the high-income market.

- Transit is used as the first egress mode for 7.8 percent of the trips by the low-income market, about 10 percent by the two middle income markets, and 15.4 of the trips by the high-income market.

- POVs are used as the first egress mode for 0.2 percent of the trips for the low-income market, 0.5 percent for the middle low-income market, 1.8 percent for the middle highincome market, and 4.3 percent for the high-income market.

\subsubsection{General}

Table 6.8 has results on the general characteristics of transit markets by household income. 
Table 6.8. General Characteristics of U.S. Transit Markets by Household Income

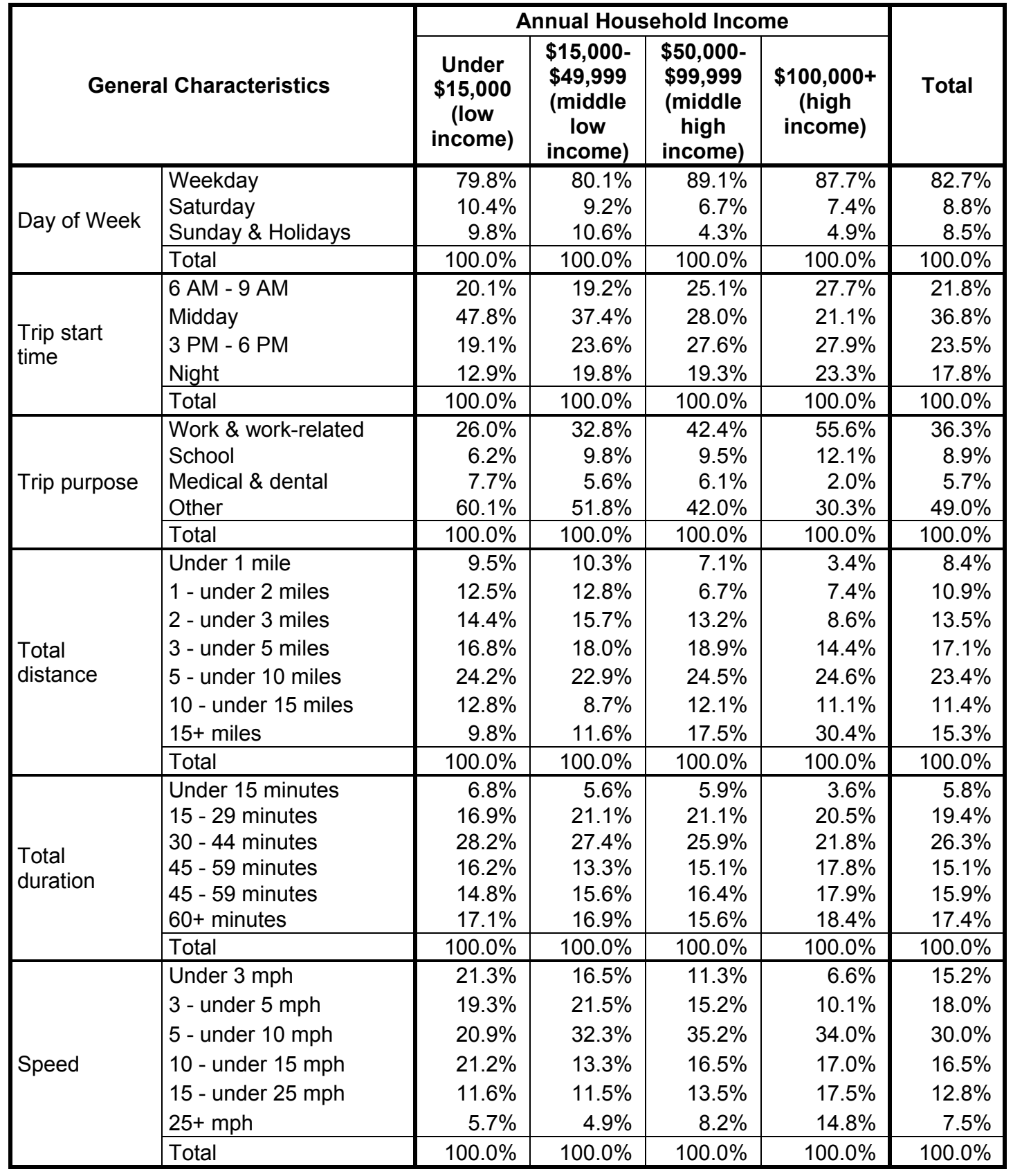

Weekend days are bigger transit markets among persons with lower income than among persons with higher income. Persons with household income under $\$ 50,000$ make about 80 percent of their transit trips on weekdays and 10 percent each on Saturdays and Sundays/holidays. Persons with income at least $\$ 50,000$, on the other hand, use transit for about 88 percent of the time on weekdays, 7 percent on Saturdays, and 5 percent on Sundays and holidays. 
Persons with lower income are far more likely to use transit during the midday period and less likely to use it during other periods. The low-income market makes 47.8 percent of their transit trips during midday, compared to 37.4 percent for the middle low-income market, 28.0 percent for the middle high-income market, and 21.1 percent for the high-income market.

The percentage of transit trips for work purposes is significantly higher for higher income markets. This percentage is 26.0 percent for the low-income market, 32.8 percent for the middle low-income market, 42.4 percent for the middle high-income market, and 55.6 percent for the high-income market.

Persons with higher income are more likely to make transit trips that are at least 15 miles long. The percentage of these long trips is 9.8 percent for the low-income market, 11.6 percent for the middle low-income market, 17.5 percent for the middle high-income market, and 30.4 percent for the highincome market. Probably as a result, persons with higher income are less likely to travel at low speeds. For example, the percentage of transit trips at speeds lower than $5 \mathrm{mph}$ is 40.6 percent for the low-income market, 38.0 percent for the middle low-income market, 26.5 percent for the middle high-income market, and 16.7 percent for the high-income market.

\subsection{Vehicle Availability}

\subsubsection{Transit-Specific}

Table 6.9 presents results on the transit-specific characteristics of transit markets by vehicle availability. Persons in zero-vehicle households are less likely than persons from households with vehicles to wait for transit for under 10 minutes, but are more likely to wait for at least 15 minutes. For example, they wait for at least 15 minutes for 31.3 percent of their transit trips, compared to 18.6-21.3 percent for persons from households with vehicles.

Persons without vehicles tend to walk more and persons with vehicles tend to use transit, POVs, and bike more as their last access mode and their first egress mode. For example, walking is used for 92.8 percent of the transit trips for persons without household vehicles vs. 84.3 percent for persons with adequate vehicles. On the other hand, POVs are used for less than one percent of the transit trips by persons without household vehicles, compared to 6.1 percent for persons with adequate vehicles.

The different transit markets with different levels of vehicle availability are largely similarly in the distribution of total access time and total egress time. 
Table 6.9. Transit-Specific Characteristics of U.S. Transit Markets by Vehicle Availability

\begin{tabular}{|c|c|c|c|c|c|}
\hline \multicolumn{2}{|c|}{ Transit-Specific Characteristics } & \multicolumn{3}{|c|}{$\begin{array}{l}\text { Vehicles Available } \\
\text { Relative to Workers }\end{array}$} & \multirow[b]{2}{*}{ Total } \\
\hline & & \multirow{5}{*}{$\begin{array}{r}\begin{array}{c}\text { Zero } \\
\text { Vehicle }\end{array} \\
18.2 \% \\
26.9 \% \\
23.6 \% \\
31.3 \% \\
\end{array}$} & \multirow{2}{*}{$\begin{array}{l}\begin{array}{c}\text { Vehicles } \\
< \\
\text { Workers }\end{array} \\
22.6 \%\end{array}$} & $\begin{array}{c}\text { Vehicles } \\
>= \\
\text { Workers }\end{array}$ & \\
\hline \multirow{5}{*}{ Wait time } & Under 5 minutes & & & $24.3 \%$ & $21.1 \%$ \\
\hline & $5-9$ minutes & & $37.4 \%$ & $30.9 \%$ & $30.1 \%$ \\
\hline & $10-14$ minutes & & $21.4 \%$ & $23.5 \%$ & $23.2 \%$ \\
\hline & $15+$ minutes & & $18.6 \%$ & $21.3 \%$ & $25.7 \%$ \\
\hline & Total & $100.0 \%$ & $100.0 \%$ & $100.0 \%$ & $100.0 \%$ \\
\hline \multirow{6}{*}{$\begin{array}{l}\text { Last access } \\
\text { mode to the } \\
\text { main mode }\end{array}$} & Walk & $92.8 \%$ & $89.8 \%$ & $84.3 \%$ & $89.3 \%$ \\
\hline & Transit & $5.2 \%$ & $7.1 \%$ & $7.0 \%$ & $6.1 \%$ \\
\hline & POV & $0.7 \%$ & $1.6 \%$ & $6.1 \%$ & $2.7 \%$ \\
\hline & Bike & $0.4 \%$ & $0.2 \%$ & $1.4 \%$ & $0.7 \%$ \\
\hline & Other & $1.0 \%$ & $1.4 \%$ & $1.2 \%$ & $1.1 \%$ \\
\hline & Total & $100.0 \%$ & $100.0 \%$ & $100.0 \%$ & $100.0 \%$ \\
\hline \multirow{6}{*}{$\begin{array}{l}\text { First egress } \\
\text { mode from the } \\
\text { main mode }\end{array}$} & Walk & $89.5 \%$ & $88.3 \%$ & $83.1 \%$ & $87.1 \%$ \\
\hline & Transit & $9.5 \%$ & $9.3 \%$ & $11.6 \%$ & $10.2 \%$ \\
\hline & POV & $0.1 \%$ & $1.1 \%$ & $2.5 \%$ & $1.1 \%$ \\
\hline & Bike & $0.3 \%$ & $0.2 \%$ & $1.2 \%$ & $0.6 \%$ \\
\hline & Other & $0.5 \%$ & $1.2 \%$ & $1.6 \%$ & $1.0 \%$ \\
\hline & Total & $100.0 \%$ & $100.0 \%$ & $100.0 \%$ & $100.0 \%$ \\
\hline \multirow{5}{*}{$\begin{array}{l}\text { Total access } \\
\text { time }\end{array}$} & Under 5 minutes & $37.3 \%$ & $31.2 \%$ & $34.4 \%$ & $35.2 \%$ \\
\hline & 5 - 9 minutes & $33.6 \%$ & $35.8 \%$ & $33.6 \%$ & $34.0 \%$ \\
\hline & $10-14$ minutes & $14.9 \%$ & $18.2 \%$ & $15.7 \%$ & $15.7 \%$ \\
\hline & $15+$ minutes & $14.3 \%$ & $14.8 \%$ & $16.3 \%$ & $15.1 \%$ \\
\hline & Total & $100.0 \%$ & $100.0 \%$ & $100.0 \%$ & $100.0 \%$ \\
\hline \multirow{5}{*}{$\begin{array}{l}\text { Total egress } \\
\text { time }\end{array}$} & Under 5 minutes & $34.2 \%$ & $32.3 \%$ & $34.6 \%$ & $34.0 \%$ \\
\hline & 5 - 9 minutes & $32.7 \%$ & $32.5 \%$ & $31.1 \%$ & $32.1 \%$ \\
\hline & $10-14$ minutes & $15.2 \%$ & $16.2 \%$ & $13.7 \%$ & $14.8 \%$ \\
\hline & $15+$ minutes & $18.0 \%$ & $19.0 \%$ & $20.6 \%$ & $19.1 \%$ \\
\hline & Total & $100.0 \%$ & $100.0 \%$ & $100.0 \%$ & $100.0 \%$ \\
\hline
\end{tabular}

\subsubsection{General}

Table 6.10 has results on the general characteristics of transit markets by vehicle availability.

Persons in zero-vehicle households are far more likely than persons with household vehicles to use transit during midday and on weekend days and holidays. They make 42.7 percent of their transit trips during the midday period vs. 29.3-32.4 percent for persons with household vehicles. They make over a quarter of their transit trips $(25.6 \%)$ on Saturdays, Sundays, and holidays. In contrast, persons with household vehicles make 8.6-10.1 percent of their transit trips on weekend days and holidays. One likely reason for these differences in transit use by time of day and day type is that a larger share of persons without household vehicles is likely not to be in the workforce. Another possible reason is that when they are employed, their work schedule does not follow the typical schedule of 8 am to $5 \mathrm{pm}$ on weekdays. 
Table 6.10. General Characteristics of U.S. Transit Markets by Vehicle Availability

\begin{tabular}{|c|c|c|c|c|c|}
\hline \multirow{2}{*}{\multicolumn{2}{|c|}{ General Characteristics }} & \multicolumn{3}{|c|}{$\begin{array}{l}\text { Vehicles Available } \\
\text { Relative to Workers }\end{array}$} & \multirow[b]{2}{*}{ Total } \\
\hline & & $\begin{array}{c}\text { Zero } \\
\text { Vehicle }\end{array}$ & $\begin{array}{c}\text { Vehicles } \\
< \\
\text { Workers }\end{array}$ & $\begin{array}{c}\text { Vehicles } \\
>= \\
\text { Workers }\end{array}$ & \\
\hline \multirow{4}{*}{ Day of week } & Weekday & $74.4 \%$ & $91.5 \%$ & $89.9 \%$ & $82.7 \%$ \\
\hline & Saturday & $12.3 \%$ & $5.6 \%$ & $5.6 \%$ & $8.8 \%$ \\
\hline & Sunday \& Holidays & $13.3 \%$ & $3.0 \%$ & $4.5 \%$ & $8.5 \%$ \\
\hline & Total & $100.0 \%$ & $100.0 \%$ & $100.0 \%$ & $100.0 \%$ \\
\hline \multirow{5}{*}{ Trip start time } & $6 \mathrm{AM}-9 \mathrm{AM}$ & $17.0 \%$ & $27.8 \%$ & $25.5 \%$ & $21.8 \%$ \\
\hline & Midday & $42.7 \%$ & $29.3 \%$ & $32.4 \%$ & $36.8 \%$ \\
\hline & 3 PM - 6 PM & $21.6 \%$ & $23.9 \%$ & $26.0 \%$ & $23.5 \%$ \\
\hline & Night & $18.7 \%$ & $19.0 \%$ & $16.0 \%$ & $17.8 \%$ \\
\hline & Total & $100.0 \%$ & $100.0 \%$ & $100.0 \%$ & $100.0 \%$ \\
\hline \multirow{5}{*}{ Trip purpose } & Work \& work-related & $26.8 \%$ & $57.1 \%$ & $39.2 \%$ & $36.3 \%$ \\
\hline & School & $4.7 \%$ & $15.7 \%$ & $11.4 \%$ & $8.9 \%$ \\
\hline & Medical \& dental & $7.7 \%$ & $2.1 \%$ & $4.8 \%$ & $5.7 \%$ \\
\hline & Other & $60.8 \%$ & $25.1 \%$ & $44.5 \%$ & $49.0 \%$ \\
\hline & Total & $100.0 \%$ & $100.0 \%$ & $100.0 \%$ & $100.0 \%$ \\
\hline \multirow{8}{*}{ Total distance } & Under 1 mile & $9.7 \%$ & $7.0 \%$ & $7.3 \%$ & $8.4 \%$ \\
\hline & 1 - under 2 miles & $17.1 \%$ & $5.7 \%$ & $5.5 \%$ & $10.9 \%$ \\
\hline & 2 - under 3 miles & $16.6 \%$ & $16.1 \%$ & $8.4 \%$ & $13.5 \%$ \\
\hline & 3 - under 5 miles & $18.6 \%$ & $17.8 \%$ & $14.9 \%$ & $17.1 \%$ \\
\hline & 5 - under 10 miles & $19.6 \%$ & $24.6 \%$ & $27.7 \%$ & $23.4 \%$ \\
\hline & 10 - under 15 miles & $8.6 \%$ & $14.2 \%$ & $13.6 \%$ & $11.4 \%$ \\
\hline & $15+$ miles & $9.9 \%$ & $14.5 \%$ & $22.6 \%$ & $15.3 \%$ \\
\hline & Total & $100.0 \%$ & $100.0 \%$ & $100.0 \%$ & $100.0 \%$ \\
\hline \multirow{7}{*}{ Total duration } & Under 15 minutes & $6.5 \%$ & $3.7 \%$ & $5.9 \%$ & $5.8 \%$ \\
\hline & $15-29$ minutes & $21.0 \%$ & $18.4 \%$ & $17.9 \%$ & $19.4 \%$ \\
\hline & $30-44$ minutes & $26.2 \%$ & $30.5 \%$ & $24.5 \%$ & $26.3 \%$ \\
\hline & 45 - 59 minutes & $15.3 \%$ & $13.6 \%$ & $15.6 \%$ & $15.1 \%$ \\
\hline & 45 - 59 minutes & $14.3 \%$ & $18.2 \%$ & $16.9 \%$ & $15.9 \%$ \\
\hline & $60+$ minutes & $16.8 \%$ & $15.6 \%$ & $19.2 \%$ & $17.4 \%$ \\
\hline & Total & $100.0 \%$ & $100.0 \%$ & $100.0 \%$ & $100.0 \%$ \\
\hline \multirow{7}{*}{ Speed } & Under $3 \mathrm{mph}$ & $20.0 \%$ & $11.3 \%$ & $10.8 \%$ & $15.2 \%$ \\
\hline & 3 - under $5 \mathrm{mph}$ & $23.2 \%$ & $18.6 \%$ & $11.3 \%$ & $18.0 \%$ \\
\hline & 5 - under $10 \mathrm{mph}$ & $27.8 \%$ & $32.6 \%$ & $31.6 \%$ & $30.0 \%$ \\
\hline & $10-$ under $15 \mathrm{mph}$ & $15.5 \%$ & $16.3 \%$ & $17.9 \%$ & $16.5 \%$ \\
\hline & 15 - under $25 \mathrm{mph}$ & $9.3 \%$ & $16.4 \%$ & $15.5 \%$ & $12.8 \%$ \\
\hline & $25+\mathrm{mph}$ & $4.2 \%$ & $4.8 \%$ & $12.9 \%$ & $7.5 \%$ \\
\hline & Total & $100.0 \%$ & $100.0 \%$ & $100.0 \%$ & $100.0 \%$ \\
\hline
\end{tabular}

Persons without household vehicles are significantly less likely than others to use transit for work purposes. This observation is consistent with the observation from above that they are more likely to use transit during midday and on weekend days and holidays. The percentage of transit trips for work purposes is 26.8 percent for persons without vehicles, 57.1 percent for households with inadequate vehicles, and 39.2 percent for households with adequate vehicles. One possible reason for the particularly high percentage of transit trips for work purposes by persons with inadequate vehicles is that a higher proportion of the transit users in this market are workers than in the other two markets. 
Persons without vehicles are less likely to use transit for trips at least 5 miles long and are more likely to experience speeds less than $5 \mathrm{mph}$ when using transit. The share of transit trips that are at least 5 miles long is 38.1 percent for persons without vehicles, 53.3 percent for persons with inadequate vehicles, and 63.9 percent for persons with adequate vehicles. At the same time, the percentage of transit trips whose overall speed is less than $5 \mathrm{mph}$ is 43.2 percent for persons without vehicles, 29.9 percent for persons with inadequate vehicles, and 22.1 percent for persons with adequate vehicles.

\subsection{Race and Ethnicity}

\subsubsection{Transit-Specific}

Table 6.11 shows results on the transit-specific characteristics of transit markets by race and ethnicity.

Table 6.11. Transit-Specific Characteristics of U.S. Transit Markets by Race and Ethnicity

\begin{tabular}{|c|c|c|c|c|c|c|}
\hline \multirow{2}{*}{\multicolumn{2}{|c|}{ Transit-Specific Characteristics }} & \multicolumn{4}{|c|}{ Race and Ethnicity } & \multirow[b]{2}{*}{ Total } \\
\hline & & \multirow{5}{*}{$\begin{array}{r}\text { Hispanic } \\
14.4 \% \\
27.9 \% \\
27.4 \% \\
30.3 \%\end{array}$} & \multirow{5}{*}{$\begin{array}{c}\begin{array}{c}\text { Non- } \\
\text { Hispanic } \\
\text { White }\end{array} \\
29.1 \% \\
34.0 \% \\
19.9 \% \\
17.0 \%\end{array}$} & \multirow{5}{*}{$\begin{array}{c}\begin{array}{c}\text { Non- } \\
\text { Hispanic } \\
\text { Black }\end{array} \\
18.1 \% \\
27.2 \% \\
21.5 \% \\
33.1 \%\end{array}$} & $\begin{array}{c}\text { Non- } \\
\text { Hispanic } \\
\text { Other } \\
\end{array}$ & \\
\hline \multirow{5}{*}{ Wait time } & Under 5 minutes & & & & $21.7 \%$ & $21.1 \%$ \\
\hline & $5-9$ minutes & & & & $32.5 \%$ & $30.1 \%$ \\
\hline & $10-14$ minutes & & & & $26.2 \%$ & $23.2 \%$ \\
\hline & $15+$ minutes & & & & $19.6 \%$ & $25.7 \%$ \\
\hline & Total & $100.0 \%$ & $100.0 \%$ & $100.0 \%$ & $100.0 \%$ & $100.0 \%$ \\
\hline \multirow{6}{*}{$\begin{array}{l}\text { Last access } \\
\text { mode to the } \\
\text { main mode }\end{array}$} & Walk & $91.8 \%$ & $86.9 \%$ & $90.4 \%$ & $85.8 \%$ & $89.3 \%$ \\
\hline & Transit & $5.9 \%$ & $6.1 \%$ & $6.2 \%$ & $6.7 \%$ & $6.1 \%$ \\
\hline & POV & $0.9 \%$ & $3.8 \%$ & $2.4 \%$ & $6.0 \%$ & $2.7 \%$ \\
\hline & Bike & $0.7 \%$ & $1.4 \%$ & $0.1 \%$ & $0.5 \%$ & $0.7 \%$ \\
\hline & Other & $0.7 \%$ & $1.8 \%$ & $1.0 \%$ & $1.0 \%$ & $1.1 \%$ \\
\hline & Total & $100.0 \%$ & $100.0 \%$ & $100.0 \%$ & $100.0 \%$ & $100.0 \%$ \\
\hline \multirow{6}{*}{$\begin{array}{l}\text { First egress } \\
\text { mode from } \\
\text { the main } \\
\text { mode }\end{array}$} & Walk & $88.9 \%$ & $84.4 \%$ & $88.4 \%$ & $84.7 \%$ & $87.1 \%$ \\
\hline & Transit & $9.7 \%$ & $11.5 \%$ & $9.2 \%$ & $11.3 \%$ & $10.2 \%$ \\
\hline & POV & $0.5 \%$ & $1.8 \%$ & $0.7 \%$ & $2.4 \%$ & $1.1 \%$ \\
\hline & Bike & $0.4 \%$ & $1.3 \%$ & $0.1 \%$ & $0.4 \%$ & $0.6 \%$ \\
\hline & Other & $0.5 \%$ & $1.0 \%$ & $1.5 \%$ & $1.2 \%$ & $1.0 \%$ \\
\hline & Total & $100.0 \%$ & $100.0 \%$ & $100.0 \%$ & $100.0 \%$ & $100.0 \%$ \\
\hline \multirow{5}{*}{$\begin{array}{l}\text { Total access } \\
\text { time }\end{array}$} & Under 5 minutes & $34.5 \%$ & $40.1 \%$ & $31.8 \%$ & $26.0 \%$ & $35.2 \%$ \\
\hline & $5-9$ minutes & $34.3 \%$ & $31.2 \%$ & $37.5 \%$ & $32.7 \%$ & $34.0 \%$ \\
\hline & $10-14$ minutes & $17.5 \%$ & $15.9 \%$ & $13.1 \%$ & $20.6 \%$ & $15.7 \%$ \\
\hline & $15+$ minutes & $13.6 \%$ & $12.8 \%$ & $17.5 \%$ & $20.7 \%$ & $15.1 \%$ \\
\hline & Total & $100.0 \%$ & $100.0 \%$ & $100.0 \%$ & $100.0 \%$ & $100.0 \%$ \\
\hline \multirow{5}{*}{$\begin{array}{l}\text { Total egress } \\
\text { time }\end{array}$} & Under 5 minutes & $31.1 \%$ & $39.4 \%$ & $32.5 \%$ & $22.8 \%$ & $34.0 \%$ \\
\hline & 5 - 9 minutes & $33.9 \%$ & $29.9 \%$ & $32.1 \%$ & $36.8 \%$ & $32.1 \%$ \\
\hline & $10-14$ minutes & $17.0 \%$ & $13.4 \%$ & $14.7 \%$ & $16.3 \%$ & $14.8 \%$ \\
\hline & $15+$ minutes & $17.9 \%$ & $17.3 \%$ & $20.7 \%$ & $24.1 \%$ & $19.1 \%$ \\
\hline & Total & $100.0 \%$ & $100.0 \%$ & $100.0 \%$ & $100.0 \%$ & $100.0 \%$ \\
\hline
\end{tabular}

Hispanics and Non-Hispanic Blacks are less likely to wait for shorter than 10 minutes and are more likely to wait for at least 15 minutes. The percentage of transit trips that involve waiting less than 10 
minutes is 42.3 percent for Hispanics, 45.3 percent for Non-Hispanic Blacks, and 63.1 percent for Non-Hispanic Whites. On the other hand, transit trips that involve waiting for at least 15 minutes are 30.3 percent for Hispanics, 33.1 percent for Non-Hispanic Blacks, and 17.0 percent for NonHispanic Whites.

Hispanics and blacks are just as likely as Non-Hispanic Whites to access the main mode by transit (about 6\%), but they are more likely to access the main mode by walking. Hispanics walk to their main mode 91.8 percent of the time and Non-Hispanic Blacks walk to their main mode 90.4 percent of the time, compared to 86.9 percent for Non-Hispanic Whites. The first egress mode follows a similar pattern for different markets by race and ethnicity. One difference is that walking plays a smaller role and transit plays a larger role than in the case of access.

\subsubsection{General}

Table 6.12 presents results on the general characteristics of transit markets by race and ethnicity. Hispanics and Non-Hispanic Blacks are more likely that Non-Hispanic Whites to use transit on weekend days and holidays. Non-Hispanic Whites make 12.4 percent of their transit trips on weekend days and holidays, compared to 23.6 percent for Hispanics and 18.2 percent for NonHispanic Blacks. In addition, Non-Hispanic Blacks are more likely than Non-Hispanic Whites to use transit during midday $(42.0 \%$ vs. $33.4 \%)$.

Hispanics and Non-Hispanic Blacks are less likely than Non-Hispanic Whites to use transit for work purposes. The percentage of transit trips for work purposes is 32.6 percent for Hispanics, 30.0 percent for Non-Hispanic Blacks, and 42.0 percent for Non-Hispanic Whites.

Hispanics and Non-Hispanic Blacks are more likely than Non-Hispanic Whites to experience speeds less than $5 \mathrm{mph}$. The percentage of transit trips with speeds less than $5 \mathrm{mph}$ is 38.3 percent of Hispanics, 40.6 percent for Non-Hispanic Blacks, and 26.3 percent for Non-Hispanic Whites. 
Table 6.12. General Characteristics of U.S. Transit Markets by Race and Ethnicity

\begin{tabular}{|c|c|c|c|c|c|c|}
\hline \multicolumn{2}{|c|}{ General Characteristics } & \multicolumn{4}{|c|}{ Race and Ethnicity } & \multirow[b]{2}{*}{ Total } \\
\hline Gener & Characteristics & Hispanic & $\begin{array}{c}\text { Non- } \\
\text { Hispanic } \\
\text { White }\end{array}$ & $\begin{array}{c}\text { Non- } \\
\text { Hispanic } \\
\text { Black } \\
\end{array}$ & $\begin{array}{c}\text { Non- } \\
\text { Hispanic } \\
\text { Other } \\
\end{array}$ & \\
\hline \multirow{4}{*}{ Day of Week } & Weekday & $76.4 \%$ & $87.6 \%$ & $81.9 \%$ & $86.1 \%$ & $82.7 \%$ \\
\hline & Saturday & $12.5 \%$ & $7.0 \%$ & $8.9 \%$ & $4.8 \%$ & $8.8 \%$ \\
\hline & Sunday \& Holidays & $11.1 \%$ & $5.4 \%$ & $9.3 \%$ & $9.1 \%$ & $8.5 \%$ \\
\hline & Total & $100.0 \%$ & $100.0 \%$ & $100.0 \%$ & $100.0 \%$ & $100.0 \%$ \\
\hline \multirow{5}{*}{ Trip start time } & 6 AM - 9 AM & $22.4 \%$ & $22.3 \%$ & $19.6 \%$ & $24.9 \%$ & $21.8 \%$ \\
\hline & Midday & $36.3 \%$ & $33.4 \%$ & $42.0 \%$ & $33.9 \%$ & $36.8 \%$ \\
\hline & 3 PM - 6 PM & $22.3 \%$ & $25.7 \%$ & $22.2 \%$ & $23.3 \%$ & $23.5 \%$ \\
\hline & Night & $19.0 \%$ & $18.5 \%$ & $16.2 \%$ & $17.9 \%$ & $17.8 \%$ \\
\hline & Total & $100.0 \%$ & $100.0 \%$ & $100.0 \%$ & $100.0 \%$ & $100.0 \%$ \\
\hline \multirow{5}{*}{ Trip purpose } & Work \& work-related & $32.6 \%$ & $42.0 \%$ & $30.0 \%$ & $49.2 \%$ & $36.3 \%$ \\
\hline & School & $11.2 \%$ & $8.0 \%$ & $7.9 \%$ & $8.9 \%$ & $8.9 \%$ \\
\hline & Medical \& dental & $7.1 \%$ & $6.9 \%$ & $4.4 \%$ & $1.9 \%$ & $5.7 \%$ \\
\hline & Other & $49.1 \%$ & $43.2 \%$ & $57.7 \%$ & $40.0 \%$ & $49.0 \%$ \\
\hline & Total & $100.0 \%$ & $100.0 \%$ & $100.0 \%$ & $100.0 \%$ & $100.0 \%$ \\
\hline \multirow{8}{*}{ Total distance } & Under 1 mile & $10.3 \%$ & $7.0 \%$ & $9.7 \%$ & $5.2 \%$ & $8.4 \%$ \\
\hline & 1 - under 2 miles & $17.1 \%$ & $7.8 \%$ & $10.3 \%$ & $8.9 \%$ & $10.9 \%$ \\
\hline & 2 - under 3 miles & $13.7 \%$ & $11.0 \%$ & $15.8 \%$ & $12.2 \%$ & $13.5 \%$ \\
\hline & 3 - under 5 miles & $17.5 \%$ & $19.0 \%$ & $15.7 \%$ & $12.4 \%$ & $17.1 \%$ \\
\hline & 5 - under 10 miles & $21.6 \%$ & $27.7 \%$ & $19.3 \%$ & $28.3 \%$ & $23.4 \%$ \\
\hline & 10 - under 15 miles & $11.2 \%$ & $9.5 \%$ & $12.5 \%$ & $15.5 \%$ & $11.4 \%$ \\
\hline & $15+$ miles & $8.6 \%$ & $18.0 \%$ & $16.6 \%$ & $17.4 \%$ & $15.3 \%$ \\
\hline & Total & $100.0 \%$ & $100.0 \%$ & $100.0 \%$ & $100.0 \%$ & $100.0 \%$ \\
\hline \multirow{7}{*}{ Total duration } & Under 15 minutes & $4.8 \%$ & $6.2 \%$ & $6.5 \%$ & $5.0 \%$ & $5.8 \%$ \\
\hline & $15-29$ minutes & $19.2 \%$ & $22.4 \%$ & $16.7 \%$ & $17.2 \%$ & $19.4 \%$ \\
\hline & $30-44$ minutes & $31.8 \%$ & $25.0 \%$ & $23.1 \%$ & $22.8 \%$ & $26.3 \%$ \\
\hline & 45 - 59 minutes & $13.9 \%$ & $15.7 \%$ & $15.5 \%$ & $17.5 \%$ & $15.1 \%$ \\
\hline & $45-59$ minutes & $16.3 \%$ & $15.2 \%$ & $15.8 \%$ & $16.0 \%$ & $15.9 \%$ \\
\hline & $60+$ minutes & $14.1 \%$ & $15.6 \%$ & $22.4 \%$ & $21.4 \%$ & $17.4 \%$ \\
\hline & Total & $100.0 \%$ & $100.0 \%$ & $100.0 \%$ & $100.0 \%$ & $100.0 \%$ \\
\hline \multirow{7}{*}{ Speed } & Under $3 \mathrm{mph}$ & $19.2 \%$ & $11.4 \%$ & $18.6 \%$ & $10.1 \%$ & $15.2 \%$ \\
\hline & 3 - under $5 \mathrm{mph}$ & $19.1 \%$ & $14.9 \%$ & $22.0 \%$ & $13.2 \%$ & $18.0 \%$ \\
\hline & 5 - under $10 \mathrm{mph}$ & $30.1 \%$ & $32.3 \%$ & $25.8 \%$ & $37.8 \%$ & $30.0 \%$ \\
\hline & $10-$ under $15 \mathrm{mph}$ & $15.5 \%$ & $15.7 \%$ & $16.8 \%$ & $19.0 \%$ & $16.5 \%$ \\
\hline & 15 - under $25 \mathrm{mph}$ & $11.3 \%$ & $16.1 \%$ & $10.6 \%$ & $12.4 \%$ & $12.8 \%$ \\
\hline & $25+\mathrm{mph}$ & $4.9 \%$ & $9.7 \%$ & $6.1 \%$ & $7.3 \%$ & $7.5 \%$ \\
\hline & Total & $100.0 \%$ & $100.0 \%$ & $100.0 \%$ & $100.0 \%$ & $100.0 \%$ \\
\hline
\end{tabular}

\subsection{Monthly Frequency of Transit Use}

\subsubsection{Transit-Specific}

Table 6.13 shows results on the transit-specific characteristics of transit markets by frequency of use. The three frequency-based markets are similar in their choice of the last access mode and the first egress mode. No significant differences in total access time and total egress time are observed across these markets either. However, the most frequent users are less likely than other transit users to wait 15 minutes or longer. The percentage of transit trips involving waiting of at least 15 
minutes is 21.5 percent for the most frequent users, 25.8 percent for medium-frequency users, and 35.4 percent for the least frequent users.

Table 6.13. Transit-Specific Characteristics of U.S. Transit Markets by Frequency of Use

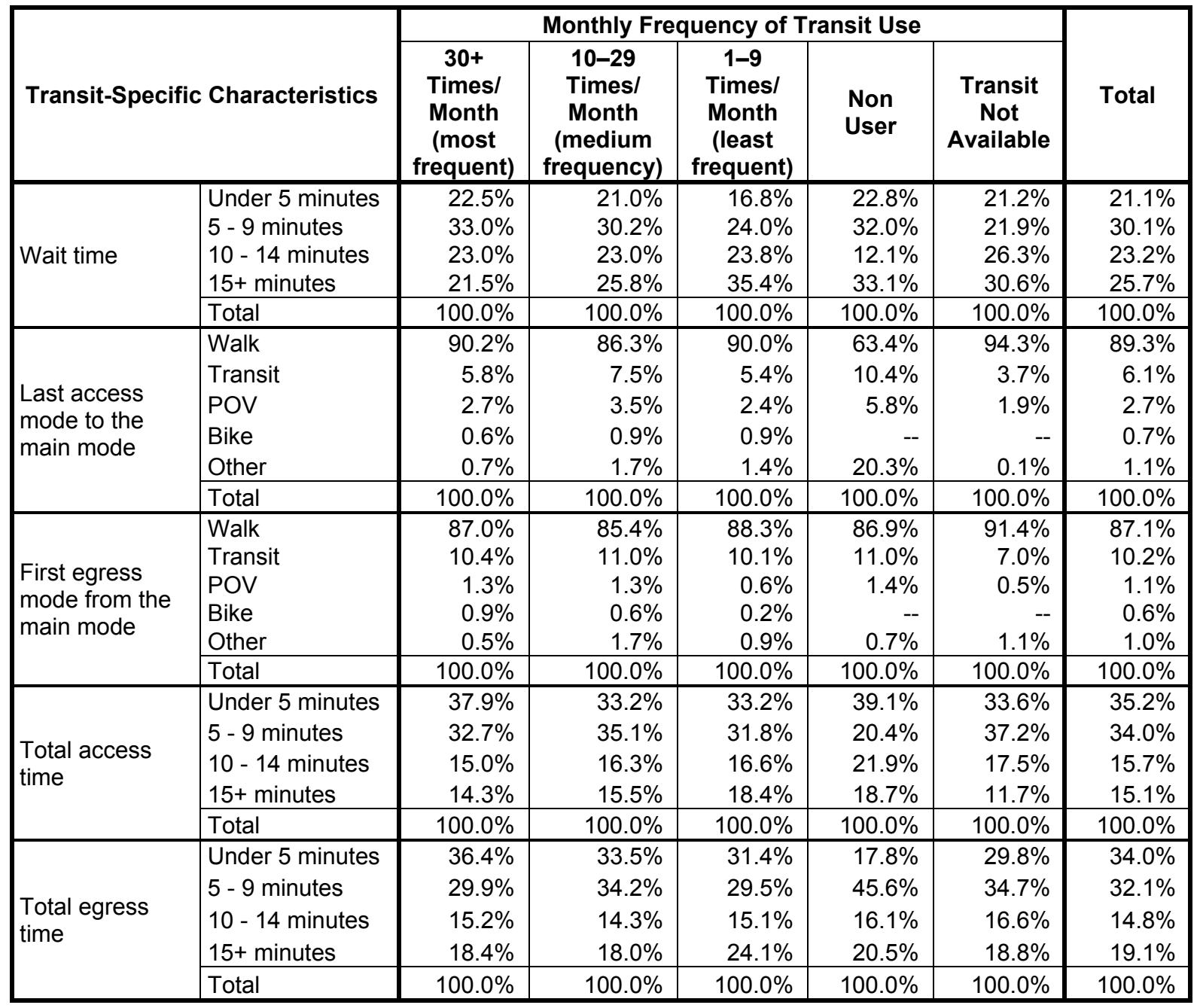

\subsubsection{General}

Table 6.14 has results on the general characteristics of transit markets by frequency of transit use. Persons who use transit more frequently are more likely to use transit on weekdays and less likely on Saturdays. For example, the most frequent users make 85.1 percent of their transit trips on weekdays and 5.6 percent on Saturdays. On the other hand, the least frequent users make 79.6 percent of their transit trips on weekdays and 11.6 percent on Saturdays. No particular pattern is observed for Sundays and holidays.

Frequent users are significantly more likely to use transit for work purposes. For the most frequent users (30+ times per month), 45.5 percent of their transit trips are for work purposes, compared to only 12.4 for the least frequent users (1-9 times per month). On the other hand, the less frequent 
users are more likely to use transit for medical and dental purposes. For example, 12.9 percent of the transit trips by the least frequent users are for medical and dental purposes vs. only 4.0 percent by the most frequent users.

Table 6.14. General Characteristics of U.S. Transit Markets by Frequency of Use

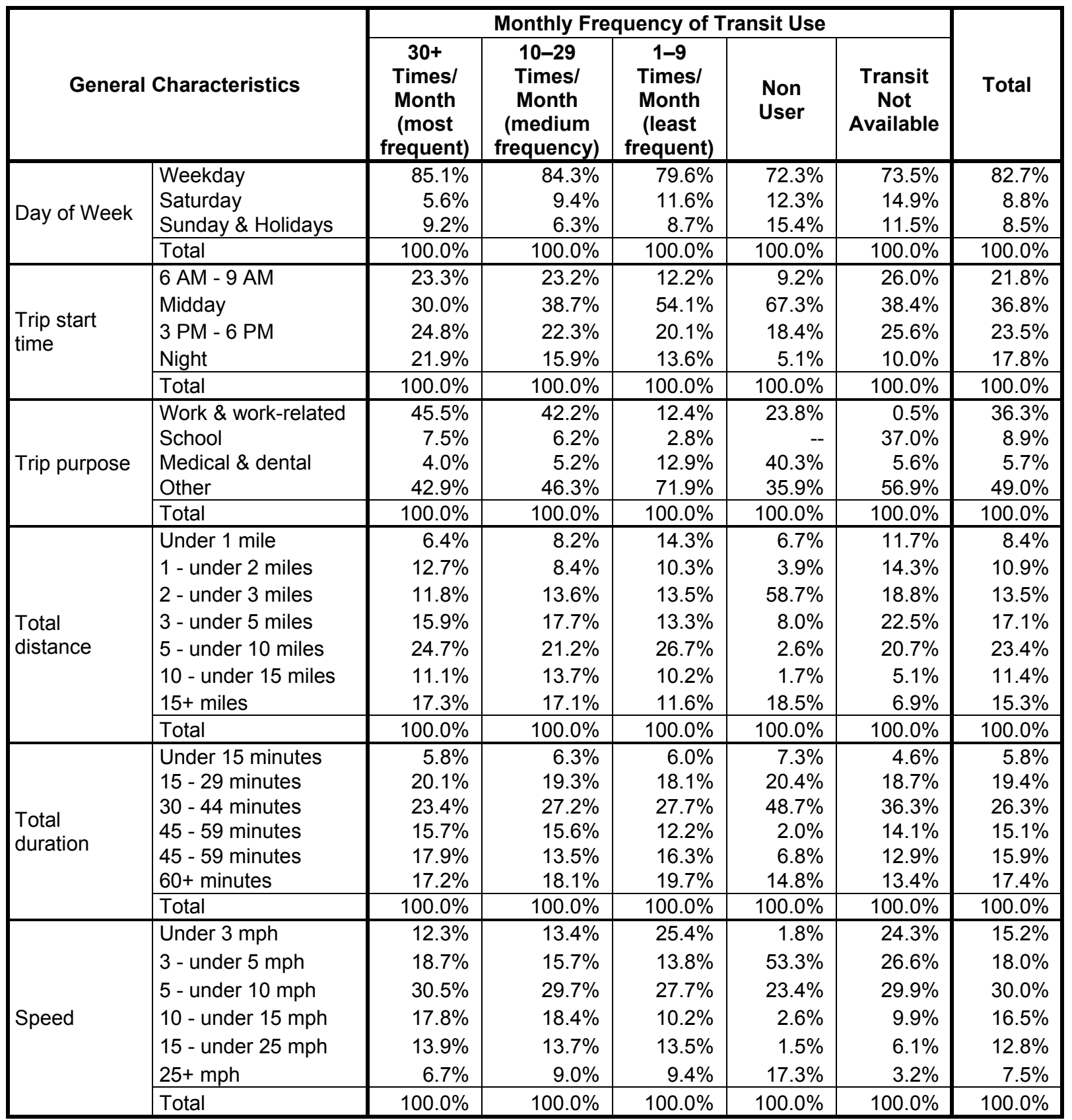




\subsection{Trip Purpose}

\subsubsection{Transit-Specific}

Table 6.15 presents results on the transit-specific characteristics of transit markets by trip purpose. Transit trips for both work and school purposes experience less waiting than other purposes. As observed from the general characteristics presented later, one likely reason for less waiting for work and school trips is that these trips are more concentrated in peak periods when transit service is typically provided with higher frequency levels.

Table 6.15. Transit-Specific Characteristics of U.S. Transit Markets by Trip Purpose

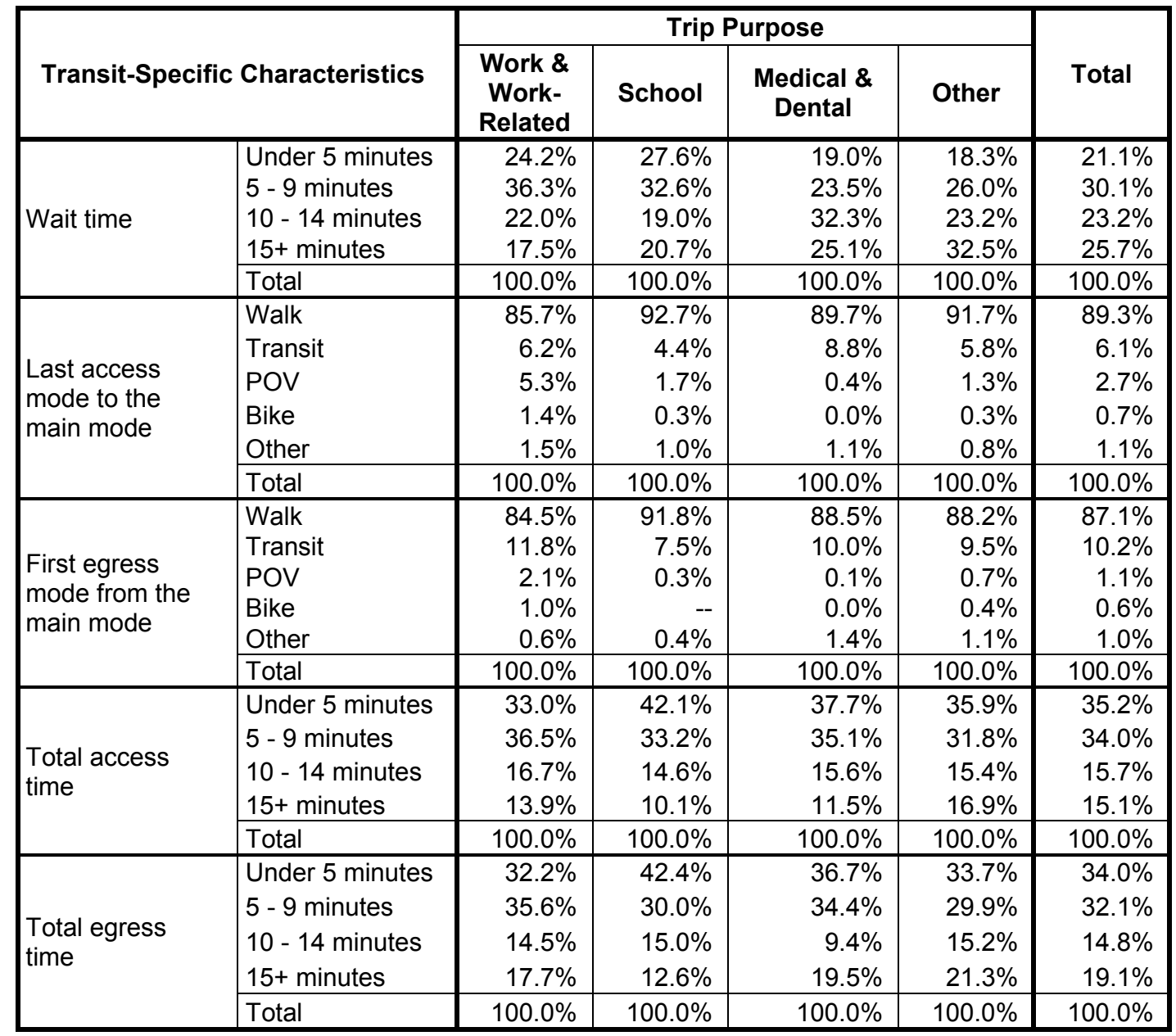

Transit trips for work purposes rely less on walking and more on other modes for both access and egress than transit trips for other purposes. For example, walking is the last access mode for 85.7 percent of the transit trips for work purposes, compared to 92.7 percent for school trips, 89.7 percent for medical and dental purposes, and 91.7 percent for all other purposes. In addition, POVs and biking are more likely to be used as the last access mode, but transit is more likely to be used as the first egress mode for work purposes. POVs are used as the last access mode for 5.3 percent of the transit trips for work purposes, compared to 2.1 percent as the first egress mode. On 
the other hand, transit is used as the last access mode for 6.2 percent of the transit trips for work purposes, compared to 11.8 percent as the first egress mode.

Both total access time and total egress time are less than 5 minutes for about one-third of transit trips for work purposes. For other purposes, particularly school trips, a larger proportion of the transit trips involve total access time and total egress time less than 5 minutes.

\subsubsection{General}

Table 6.16 shows results on the general characteristics of transit markets by trip purpose. Most of the transit trips for work purposes occur on weekdays and during peak periods, but a significant share of them are made on weekend days and during off-peak times. Only 7.4 percent of transit trips for work purposes occur on weekend days and holidays, with 4.3 percent on Saturdays and 3.1 percent on Sundays and holidays. More significant, 39.2 percent of the work trips by transit are made during midday and at night, with 23.7 percent during midday and 15.5 percent at night.

Transit trips for work purposes are far more likely to be at least 15 miles long than for most of other purposes. For all other purposes, about 10 percent of the transit trips are at least 15 miles long. For work purpose, in comparison, 23.1 percent of the transit trips are at least 15 miles. When compared to work purposes, on the other hand, transit trips for medical and dental purposes are far more likely to last at least 60 minutes and at speeds lower than $3 \mathrm{mph}$. The percentage of transit trips lasting at least 60 minutes is 31.3 percent for medical and dental purposes and 20.5 percent for work purposes. The percentage of transit trips at speeds lower than $5 \mathrm{mph}$ is 47.8 percent for medical and dental purposes and 25.5 percent for work purposes.

\subsection{Summary}

This section summarizes the transit-specific and general characteristics of various transit markets. Similar to the summary for the previous sections, this summary also focuses on the nine key transit markets. These key transit markets are:

- Non-drivers

- New immigrants

- Having medical conditions

- Income under $\$ 15,000$

- Zero vehicle Households

- Hispanics

- Non-Hispanic Blacks

- Most frequent users

- Work purposes 
Tables 6.17 and 6.18 contain the transit-specific and general characteristics of these key transit markets. This discussion mostly is based on comparing each of these key transit markets with the entire transit market.

Table 6.16. General Characteristics of U.S. Transit Markets by Trip Purpose

\begin{tabular}{|c|c|c|c|c|c|c|}
\hline \multirow{2}{*}{\multicolumn{2}{|c|}{ General Characteristics }} & \multicolumn{4}{|c|}{ Trip Purpose } & \multirow[b]{2}{*}{ Total } \\
\hline & & $\begin{array}{c}\text { Work \& } \\
\text { Work } \\
\text { Related }\end{array}$ & School & $\begin{array}{c}\text { Medical/ } \\
\text { Dental }\end{array}$ & Other & \\
\hline \multirow[t]{2}{*}{ Day of week } & $\begin{array}{l}\text { Weekday } \\
\text { Saturday } \\
\text { Sunday \& Holidays }\end{array}$ & $\begin{array}{r}92.6 \% \\
4.3 \% \\
3.1 \% \\
\end{array}$ & $\begin{array}{r}98.1 \% \\
1.7 \% \\
0.2 \% \\
\end{array}$ & $\begin{array}{r}94.9 \% \\
2.9 \% \\
2.2 \% \\
\end{array}$ & $\begin{array}{l}71.6 \% \\
14.1 \% \\
14.3 \% \\
\end{array}$ & $\begin{array}{r}82.7 \% \\
8.8 \% \\
8.5 \% \\
\end{array}$ \\
\hline & Total & $100.0 \%$ & $100.0 \%$ & $100.0 \%$ & $100.0 \%$ & $100.0 \%$ \\
\hline \multirow{5}{*}{ Trip start time } & $6 A M-9 A M$ & $33.5 \%$ & $38.8 \%$ & $17.3 \%$ & $10.5 \%$ & $21.8 \%$ \\
\hline & Midday & $23.7 \%$ & $30.0 \%$ & $57.6 \%$ & $45.0 \%$ & $36.8 \%$ \\
\hline & $3 P M-6 P M$ & $27.4 \%$ & $22.1 \%$ & $21.3 \%$ & $21.7 \%$ & $23.5 \%$ \\
\hline & Night & $15.5 \%$ & $9.0 \%$ & $3.8 \%$ & $22.8 \%$ & $17.8 \%$ \\
\hline & Total & $100.0 \%$ & $100.0 \%$ & $100.0 \%$ & $100.0 \%$ & $100.0 \%$ \\
\hline \multirow{8}{*}{ Total distance } & Under 1 mile & $4.1 \%$ & $7.7 \%$ & $8.5 \%$ & $11.2 \%$ & $8.4 \%$ \\
\hline & 1 - under 2 miles & $5.5 \%$ & $7.8 \%$ & $9.8 \%$ & $15.8 \%$ & $10.9 \%$ \\
\hline & 2 - under 3 miles & $11.8 \%$ & $18.0 \%$ & $18.8 \%$ & $13.5 \%$ & $13.5 \%$ \\
\hline & 3 - under 5 miles & $14.4 \%$ & $19.0 \%$ & $15.5 \%$ & $19.1 \%$ & $17.1 \%$ \\
\hline & 5 - under 10 miles & $27.3 \%$ & $26.7 \%$ & $29.3 \%$ & $19.4 \%$ & $23.4 \%$ \\
\hline & 10 - under 15 miles & $13.7 \%$ & $8.0 \%$ & $7.6 \%$ & $10.8 \%$ & $11.4 \%$ \\
\hline & $15+$ miles & $23.1 \%$ & $12.8 \%$ & $10.6 \%$ & $10.2 \%$ & $15.3 \%$ \\
\hline & Total & $100.0 \%$ & $100.0 \%$ & $100.0 \%$ & $100.0 \%$ & $100.0 \%$ \\
\hline \multirow{7}{*}{ Total duration } & Under 15 minutes & $3.3 \%$ & $6.7 \%$ & $1.2 \%$ & $8.0 \%$ & $5.8 \%$ \\
\hline & 15 - 29 minutes & $15.1 \%$ & $22.2 \%$ & $15.9 \%$ & $23.0 \%$ & $19.4 \%$ \\
\hline & $30-44$ minutes & $23.5 \%$ & $30.3 \%$ & $26.0 \%$ & $27.3 \%$ & $26.3 \%$ \\
\hline & 45 - 59 minutes & $16.8 \%$ & $16.3 \%$ & $12.8 \%$ & $14.2 \%$ & $15.1 \%$ \\
\hline & 45 - 59 minutes & $20.8 \%$ & $12.8 \%$ & $12.6 \%$ & $13.3 \%$ & $15.9 \%$ \\
\hline & $60+$ minutes & $20.5 \%$ & $11.7 \%$ & $31.3 \%$ & $14.1 \%$ & $17.4 \%$ \\
\hline & Total & $100.0 \%$ & $100.0 \%$ & $100.0 \%$ & $100.0 \%$ & $100.0 \%$ \\
\hline \multirow{7}{*}{ Speed } & Under $3 \mathrm{mph}$ & $8.4 \%$ & $12.8 \%$ & $21.4 \%$ & $19.6 \%$ & $15.2 \%$ \\
\hline & 3 - under $5 \mathrm{mph}$ & $17.1 \%$ & $20.3 \%$ & $26.4 \%$ & $17.4 \%$ & $18.0 \%$ \\
\hline & 5 - under $10 \mathrm{mph}$ & $30.1 \%$ & $32.1 \%$ & $26.0 \%$ & $30.3 \%$ & $30.0 \%$ \\
\hline & 10 - under $15 \mathrm{mph}$ & $20.9 \%$ & $13.8 \%$ & $8.9 \%$ & $14.4 \%$ & $16.5 \%$ \\
\hline & 15 - under $25 \mathrm{mph}$ & $14.7 \%$ & $15.1 \%$ & $15.9 \%$ & $10.7 \%$ & $12.8 \%$ \\
\hline & $25+\mathrm{mph}$ & $8.8 \%$ & $5.9 \%$ & $1.5 \%$ & $7.5 \%$ & $7.5 \%$ \\
\hline & Total & $100.0 \%$ & $100.0 \%$ & $100.0 \%$ & $100.0 \%$ & $100.0 \%$ \\
\hline
\end{tabular}

\subsubsection{Non-Drivers}

Non-drivers use transit far more likely on weekend days and holidays and during midday and night times. They are extremely less likely to use transit for work purposes, with about 10 percent of their transit trips for work vs. 36.3 percent for the entire transit market. Their trips are more likely to be shorter than 5 miles, take under 45 minutes, and be at speeds lower than $5 \mathrm{mph}$. They are more likely to wait at least 10 minutes. They are just as likely as any other transit user to walk for access or egress. They are more likely to use transit for access. Their total access time and total egress time are more likely to be at least 10 minutes. 
Table 6.17. Summary of Transit-Specific Characteristics for Key U.S. Transit Markets

\begin{tabular}{|c|c|c|c|c|c|c|c|c|c|c|c|}
\hline \multicolumn{2}{|c|}{$\begin{array}{l}\text { Transit-Specific } \\
\text { Characteristics }\end{array}$} & \multirow{2}{*}{$\begin{array}{r}\text { Non-Driver } \\
15.6 \%\end{array}$} & \multirow{2}{*}{$\begin{array}{c}\begin{array}{c}\text { New } \\
\text { Immigrant }\end{array} \\
14.9 \%\end{array}$} & \multirow{2}{*}{\begin{tabular}{r|}
$\begin{array}{c}\text { Having } \\
\text { Medical } \\
\text { Conditions }\end{array}$ \\
$13.4 \%$ \\
\end{tabular}} & \multirow{2}{*}{$\begin{array}{r}\begin{array}{c}\text { Under } \\
\mathbf{\$ 1 5 , 0 0 0}\end{array} \\
12.0 \%\end{array}$} & \multirow{2}{*}{\begin{tabular}{|r|}
$\begin{array}{c}\text { Zero } \\
\text { Vehicle } \\
\text { Households }\end{array}$ \\
$18.2 \%$ \\
\end{tabular}} & \multirow{2}{*}{\begin{tabular}{r|} 
Hispanic \\
$14.4 \%$
\end{tabular}} & \multirow{2}{*}{$\begin{array}{r}\begin{array}{c}\text { Non- } \\
\text { Hispanic } \\
\text { Black }\end{array} \\
18.1 \%\end{array}$} & \multirow{2}{*}{\begin{tabular}{|c|}
$\begin{array}{c}\text { Most } \\
\text { Frequent } \\
\text { User }\end{array}$ \\
$22.5 \%$
\end{tabular}} & \multirow{2}{*}{$\begin{array}{r}\text { Work } \\
24.2 \%\end{array}$} & \multirow{2}{*}{$\begin{array}{l}\text { Total } \\
21.1 \%\end{array}$} \\
\hline \multirow{5}{*}{ Wait time } & Under 5 minutes & & & & & & & & & & \\
\hline & $5-9$ minutes & $22.1 \%$ & $31.7 \%$ & $17.5 \%$ & $23.4 \%$ & $26.9 \%$ & $27.9 \%$ & $27.2 \%$ & $33.0 \%$ & $36.3 \%$ & $30.1 \%$ \\
\hline & $10-14$ minutes & $27.9 \%$ & $24.7 \%$ & $24.7 \%$ & $23.3 \%$ & $23.6 \%$ & $27.4 \%$ & $21.5 \%$ & $23.0 \%$ & $22.0 \%$ & $23.2 \%$ \\
\hline & $15+$ minutes & $34.4 \%$ & $28.6 \%$ & $44.4 \%$ & $41.4 \%$ & $31.3 \%$ & $30.3 \%$ & $33.1 \%$ & $21.5 \%$ & $17.5 \%$ & $25.7 \%$ \\
\hline & Total & $100.0 \%$ & $100.0 \%$ & $100.0 \%$ & $100.0 \%$ & $100.0 \%$ & $100.0 \%$ & $100.0 \%$ & $100.0 \%$ & $100.0 \%$ & $100.0 \%$ \\
\hline \multirow{6}{*}{$\begin{array}{l}\text { Last } \\
\text { access } \\
\text { mode to } \\
\text { the main } \\
\text { mode }\end{array}$} & POV & $87.3 \%$ & $91.1 \%$ & $91.5 \%$ & $94.2 \%$ & $92.8 \%$ & $91.8 \%$ & $90.4 \%$ & $90.2 \%$ & $85.7 \%$ & $89.3 \%$ \\
\hline & Transit & $8.8 \%$ & $5.8 \%$ & $4.8 \%$ & $3.9 \%$ & $5.2 \%$ & $5.9 \%$ & $6.2 \%$ & $5.8 \%$ & $6.2 \%$ & $6.1 \%$ \\
\hline & Walk & $1.1 \%$ & $1.8 \%$ & $0.8 \%$ & $0.5 \%$ & $0.7 \%$ & $0.9 \%$ & $2.4 \%$ & $2.7 \%$ & $5.3 \%$ & $2.7 \%$ \\
\hline & Bike & $0.2 \%$ & $0.9 \%$ & $0.5 \%$ & $0.5 \%$ & $0.4 \%$ & $0.7 \%$ & $0.1 \%$ & $0.6 \%$ & $1.4 \%$ & $0.7 \%$ \\
\hline & Other & $2.5 \%$ & $0.4 \%$ & $2.4 \%$ & $0.8 \%$ & $1.0 \%$ & $0.7 \%$ & $1.0 \%$ & $0.7 \%$ & $1.5 \%$ & $1.1 \%$ \\
\hline & Total & $100.0 \%$ & $100.0 \%$ & $100.0 \%$ & $100.0 \%$ & $100.0 \%$ & $100.0 \%$ & $100.0 \%$ & $100.0 \%$ & $100.0 \%$ & $100.0 \%$ \\
\hline \multirow{6}{*}{$\begin{array}{l}\text { First } \\
\text { egress } \\
\text { mode from } \\
\text { the main } \\
\text { mode }\end{array}$} & POV & $86.4 \%$ & $88.0 \%$ & $88.5 \%$ & $90.5 \%$ & $89.5 \%$ & $88.9 \%$ & $88.4 \%$ & $87.0 \%$ & $84.5 \%$ & $87.1 \%$ \\
\hline & Transit & $10.5 \%$ & $10.7 \%$ & $7.5 \%$ & $7.8 \%$ & $9.5 \%$ & $9.7 \%$ & $9.2 \%$ & $10.4 \%$ & $11.8 \%$ & $10.2 \%$ \\
\hline & Walk & $0.9 \%$ & $0.4 \%$ & $1.6 \%$ & $0.2 \%$ & $0.1 \%$ & $0.5 \%$ & $0.7 \%$ & $1.3 \%$ & $2.1 \%$ & $1.1 \%$ \\
\hline & Bike & -- & $0.6 \%$ & $0.4 \%$ & $0.4 \%$ & $0.3 \%$ & $0.4 \%$ & $0.1 \%$ & $0.9 \%$ & $1.0 \%$ & $0.6 \%$ \\
\hline & Other & $2.2 \%$ & $0.3 \%$ & $2.0 \%$ & $1.0 \%$ & $0.5 \%$ & $0.5 \%$ & $1.5 \%$ & $0.5 \%$ & $0.6 \%$ & $1.0 \%$ \\
\hline & Total & $100.0 \%$ & $100.0 \%$ & $100.0 \%$ & $100.0 \%$ & $100.0 \%$ & $100.0 \%$ & $100.0 \%$ & $100.0 \%$ & $100.0 \%$ & $100.0 \%$ \\
\hline \multirow{5}{*}{$\begin{array}{l}\text { Total } \\
\text { access } \\
\text { time }\end{array}$} & Under 5 minutes & $36.1 \%$ & $29.3 \%$ & $32.6 \%$ & $32.9 \%$ & $37.3 \%$ & $34.5 \%$ & $31.8 \%$ & $37.9 \%$ & $33.0 \%$ & $35.2 \%$ \\
\hline & 5 - 9 minutes & $28.0 \%$ & $32.5 \%$ & $31.4 \%$ & $33.5 \%$ & $33.6 \%$ & $34.3 \%$ & $37.5 \%$ & $32.7 \%$ & $36.5 \%$ & $34.0 \%$ \\
\hline & $10-14$ minutes & $17.7 \%$ & $24.0 \%$ & $14.7 \%$ & $17.3 \%$ & $14.9 \%$ & $17.5 \%$ & $13.1 \%$ & $15.0 \%$ & $16.7 \%$ & $15.7 \%$ \\
\hline & $15+$ minutes & $18.2 \%$ & $14.3 \%$ & $21.3 \%$ & $16.2 \%$ & $14.3 \%$ & $13.6 \%$ & $17.5 \%$ & $14.3 \%$ & $13.9 \%$ & $15.1 \%$ \\
\hline & Total & $100.0 \%$ & $100.0 \%$ & $100.0 \%$ & $100.0 \%$ & $100.0 \%$ & $100.0 \%$ & $100.0 \%$ & $100.0 \%$ & $100.0 \%$ & $100.0 \%$ \\
\hline \multirow{5}{*}{$\begin{array}{l}\text { Total } \\
\text { egress } \\
\text { time }\end{array}$} & Under 5 minutes & $33.1 \%$ & $25.5 \%$ & $30.0 \%$ & $30.7 \%$ & $34.2 \%$ & $31.1 \%$ & $32.5 \%$ & $36.4 \%$ & $32.2 \%$ & $34.0 \%$ \\
\hline & 5 - 9 minutes & $24.4 \%$ & $34.1 \%$ & $28.1 \%$ & $31.7 \%$ & $32.7 \%$ & $33.9 \%$ & $32.1 \%$ & $29.9 \%$ & $35.6 \%$ & $32.1 \%$ \\
\hline & $10-14$ minutes & $16.1 \%$ & $20.6 \%$ & $17.6 \%$ & $18.2 \%$ & $15.2 \%$ & $17.0 \%$ & $14.7 \%$ & $15.2 \%$ & $14.5 \%$ & $14.8 \%$ \\
\hline & $15+$ minutes & $26.5 \%$ & $19.7 \%$ & $24.3 \%$ & $19.4 \%$ & $18.0 \%$ & $17.9 \%$ & $20.7 \%$ & $18.4 \%$ & $17.7 \%$ & $19.1 \%$ \\
\hline & Total & $100.0 \%$ & $100.0 \%$ & $100.0 \%$ & $100.0 \%$ & $100.0 \%$ & $100.0 \%$ & $100.0 \%$ & $100.0 \%$ & $100.0 \%$ & $100.0 \%$ \\
\hline
\end{tabular}


Table 6.18. Summary of General Characteristics for Key U.S. Transit Markets

\begin{tabular}{|c|c|c|c|c|c|c|c|c|c|c|c|}
\hline \multicolumn{2}{|c|}{ General Characteristics } & Non-Driver & $\begin{array}{c}\text { New } \\
\text { Immigrant }\end{array}$ & $\begin{array}{c}\text { Having } \\
\text { Medical } \\
\text { Conditions }\end{array}$ & $\begin{array}{c}\text { Under } \\
\$ 15,000\end{array}$ & $\begin{array}{c}\text { Zero } \\
\text { Vehicle } \\
\text { Households }\end{array}$ & Hispanic & $\begin{array}{l}\text { Non- } \\
\text { Hispanic } \\
\text { Black }\end{array}$ & $\begin{array}{l}\text { Most } \\
\text { Frequent } \\
\text { User }\end{array}$ & Work & Total \\
\hline \multirow{4}{*}{$\begin{array}{l}\text { Day of } \\
\text { week }\end{array}$} & Weekday & $69.3 \%$ & $80.4 \%$ & $83.7 \%$ & $79.8 \%$ & $74.4 \%$ & $76.4 \%$ & $81.9 \%$ & $85.1 \%$ & $92.6 \%$ & $82.7 \%$ \\
\hline & Saturday & $18.6 \%$ & $6.4 \%$ & $6.3 \%$ & $10.4 \%$ & $12.3 \%$ & $12.5 \%$ & $8.9 \%$ & $5.6 \%$ & $4.3 \%$ & $8.8 \%$ \\
\hline & Sunday/Holidays & $12.1 \%$ & $13.2 \%$ & $10.0 \%$ & $9.8 \%$ & $13.3 \%$ & $11.1 \%$ & $9.3 \%$ & $9.2 \%$ & $3.1 \%$ & $8.5 \%$ \\
\hline & Total & $100.0 \%$ & $100.0 \%$ & $100.0 \%$ & $100.0 \%$ & $100.0 \%$ & $100.0 \%$ & $100.0 \%$ & $100.0 \%$ & $100.0 \%$ & $100.0 \%$ \\
\hline \multirow{5}{*}{$\begin{array}{l}\text { Trip start } \\
\text { time }\end{array}$} & $6 \mathrm{AM}-9 \mathrm{AM}$ & $11.7 \%$ & $23.5 \%$ & $15.9 \%$ & $20.1 \%$ & $17.0 \%$ & $22.4 \%$ & $19.6 \%$ & $23.3 \%$ & $33.5 \%$ & $21.8 \%$ \\
\hline & Midday & $49.2 \%$ & $33.5 \%$ & $53.4 \%$ & $47.8 \%$ & $42.7 \%$ & $36.3 \%$ & $42.0 \%$ & $30.0 \%$ & $23.7 \%$ & $36.8 \%$ \\
\hline & 3 PM - 6 PM & $15.9 \%$ & $23.1 \%$ & $20.3 \%$ & $19.1 \%$ & $21.6 \%$ & $22.3 \%$ & $22.2 \%$ & $24.8 \%$ & $27.4 \%$ & $23.5 \%$ \\
\hline & Night & $23.2 \%$ & $19.9 \%$ & $10.5 \%$ & $12.9 \%$ & $18.7 \%$ & $19.0 \%$ & $16.2 \%$ & $21.9 \%$ & $15.5 \%$ & $17.8 \%$ \\
\hline & Total & $100.0 \%$ & $100.0 \%$ & $100.0 \%$ & $100.0 \%$ & $100.0 \%$ & $100.0 \%$ & $100.0 \%$ & $100.0 \%$ & $100.0 \%$ & $100.0 \%$ \\
\hline \multirow{5}{*}{$\begin{array}{l}\text { Trip } \\
\text { purpose }\end{array}$} & Work/work-related & $9.7 \%$ & $37.4 \%$ & $17.1 \%$ & $26.0 \%$ & $26.8 \%$ & $32.6 \%$ & $30.0 \%$ & $45.5 \%$ & & $36.3 \%$ \\
\hline & School & $10.1 \%$ & $13.2 \%$ & $1.4 \%$ & $6.2 \%$ & $4.7 \%$ & $11.2 \%$ & $7.9 \%$ & $7.5 \%$ & Not & $8.9 \%$ \\
\hline & Medical/dental & $11.8 \%$ & $3.6 \%$ & $18.6 \%$ & $7.7 \%$ & $7.7 \%$ & $7.1 \%$ & $4.4 \%$ & $4.0 \%$ & applicable & $5.7 \%$ \\
\hline & Other & $68.4 \%$ & $45.8 \%$ & $62.8 \%$ & $60.1 \%$ & $60.8 \%$ & $49.1 \%$ & $57.7 \%$ & $42.9 \%$ & & $49.0 \%$ \\
\hline & Total & $100.0 \%$ & $100.0 \%$ & $100.0 \%$ & $100.0 \%$ & $100.0 \%$ & $100.0 \%$ & $100.0 \%$ & $100.0 \%$ & & $100.0 \%$ \\
\hline \multirow{8}{*}{$\begin{array}{l}\text { Total } \\
\text { distance }\end{array}$} & Under 1 miles & $8.4 \%$ & $6.1 \%$ & $12.3 \%$ & $9.5 \%$ & $9.7 \%$ & $10.3 \%$ & $9.7 \%$ & $6.4 \%$ & $4.1 \%$ & $8.4 \%$ \\
\hline & 1 - under 2 miles & $15.0 \%$ & $17.1 \%$ & $10.0 \%$ & $12.5 \%$ & $17.1 \%$ & $17.1 \%$ & $10.3 \%$ & $12.7 \%$ & $5.5 \%$ & $10.9 \%$ \\
\hline & 2 - under 3 miles & $15.9 \%$ & $11.3 \%$ & $12.7 \%$ & $14.4 \%$ & $16.6 \%$ & $13.7 \%$ & $15.8 \%$ & $11.8 \%$ & $11.8 \%$ & $13.5 \%$ \\
\hline & 3 - under 5 miles & $28.9 \%$ & $19.9 \%$ & $16.3 \%$ & $16.8 \%$ & $18.6 \%$ & $17.5 \%$ & $15.7 \%$ & $15.9 \%$ & $14.4 \%$ & $17.1 \%$ \\
\hline & 5 - under 10 miles & $18.4 \%$ & $25.8 \%$ & $25.2 \%$ & $24.2 \%$ & $19.6 \%$ & $21.6 \%$ & $19.3 \%$ & $24.7 \%$ & $27.3 \%$ & $23.4 \%$ \\
\hline & 10 - under 15 miles & $4.3 \%$ & $7.8 \%$ & $10.5 \%$ & $12.8 \%$ & $8.6 \%$ & $11.2 \%$ & $12.5 \%$ & $11.1 \%$ & $13.7 \%$ & $11.4 \%$ \\
\hline & $15+$ miles & $9.0 \%$ & $12.1 \%$ & $13.0 \%$ & $9.8 \%$ & $9.9 \%$ & $8.6 \%$ & $16.6 \%$ & $17.3 \%$ & $23.1 \%$ & $15.3 \%$ \\
\hline & Total & $100.0 \%$ & $100.0 \%$ & $100.0 \%$ & $100.0 \%$ & $100.0 \%$ & $100.0 \%$ & $100.0 \%$ & $100.0 \%$ & $100.0 \%$ & $100.0 \%$ \\
\hline \multirow{7}{*}{$\begin{array}{l}\text { Total } \\
\text { duration }\end{array}$} & Under 15 minutes & $5.4 \%$ & $3.0 \%$ & $5.2 \%$ & $6.8 \%$ & $6.5 \%$ & $4.8 \%$ & $6.5 \%$ & $5.8 \%$ & $3.3 \%$ & $5.8 \%$ \\
\hline & $15-29$ minutes & $20.9 \%$ & $24.4 \%$ & $16.7 \%$ & $16.9 \%$ & $21.0 \%$ & $19.2 \%$ & $16.7 \%$ & $20.1 \%$ & $15.1 \%$ & $19.4 \%$ \\
\hline & $30-44$ minutes & $30.2 \%$ & $27.2 \%$ & $24.6 \%$ & $28.2 \%$ & $26.2 \%$ & $31.8 \%$ & $23.1 \%$ & $23.4 \%$ & $23.5 \%$ & $26.3 \%$ \\
\hline & 45 - 59 minutes & $13.0 \%$ & $15.5 \%$ & $17.0 \%$ & $16.2 \%$ & $15.3 \%$ & $13.9 \%$ & $15.5 \%$ & $15.7 \%$ & $16.8 \%$ & $15.1 \%$ \\
\hline & 45 - 59 minutes & $15.4 \%$ & $16.1 \%$ & $11.6 \%$ & $14.8 \%$ & $14.3 \%$ & $16.3 \%$ & $15.8 \%$ & $17.9 \%$ & $20.8 \%$ & $15.9 \%$ \\
\hline & $60+$ minutes & $15.1 \%$ & $13.7 \%$ & $25.0 \%$ & $17.1 \%$ & $16.8 \%$ & $14.1 \%$ & $22.4 \%$ & $17.2 \%$ & $20.5 \%$ & $17.4 \%$ \\
\hline & Total & $100.0 \%$ & $100.0 \%$ & $100.0 \%$ & $100.0 \%$ & $100.0 \%$ & $100.0 \%$ & $100.0 \%$ & $100.0 \%$ & $100.0 \%$ & $100.0 \%$ \\
\hline \multirow{7}{*}{ Speed } & Under $3 \mathrm{mph}$ & $16.4 \%$ & $12.6 \%$ & $23.1 \%$ & $21.3 \%$ & $20.0 \%$ & $19.2 \%$ & $18.6 \%$ & $12.3 \%$ & $8.4 \%$ & $15.2 \%$ \\
\hline & 3 - under $5 \mathrm{mph}$ & $31.7 \%$ & $21.1 \%$ & $17.6 \%$ & $19.3 \%$ & $23.2 \%$ & $19.1 \%$ & $22.0 \%$ & $18.7 \%$ & $17.1 \%$ & $18.0 \%$ \\
\hline & 5 - under $10 \mathrm{mph}$ & $29.6 \%$ & $31.9 \%$ & $24.4 \%$ & $20.9 \%$ & $27.8 \%$ & $30.1 \%$ & $25.8 \%$ & $30.5 \%$ & $30.1 \%$ & $30.0 \%$ \\
\hline & 10 - under $15 \mathrm{mph}$ & $8.3 \%$ & $16.1 \%$ & $16.6 \%$ & $21.2 \%$ & $15.5 \%$ & $15.5 \%$ & $16.8 \%$ & $17.8 \%$ & $20.9 \%$ & $16.5 \%$ \\
\hline & 15 - under $25 \mathrm{mph}$ & $11.2 \%$ & $9.0 \%$ & $14.7 \%$ & $11.6 \%$ & $9.3 \%$ & $11.3 \%$ & $10.6 \%$ & $13.9 \%$ & $14.7 \%$ & $12.8 \%$ \\
\hline & $25+\mathrm{mph}$ & $2.7 \%$ & $9.4 \%$ & $3.6 \%$ & $5.7 \%$ & $4.2 \%$ & $4.9 \%$ & $6.1 \%$ & $6.7 \%$ & $8.8 \%$ & $7.5 \%$ \\
\hline & Total & $100.0 \%$ & $100.0 \%$ & $100.0 \%$ & $100.0 \%$ & $100.0 \%$ & $100.0 \%$ & $100.0 \%$ & $100.0 \%$ & $100.0 \%$ & $100.0 \%$ \\
\hline
\end{tabular}




\subsubsection{New Immigrants}

New immigrants are far more likely to use transit on Sundays and holidays and slightly more likely to use transit at night. They use transit just as likely for work purposes, but far more likely for school, and less likely for medical and dental purposes. They are more likely to wait for at least 5 minutes. They are slightly more likely to walk for access or egress and are more likely to bike for egress but are far more likely to bike for access. Either their total access time or total egress time is significantly more likely to be in the range of 10-14 minutes.

\subsubsection{Having Medical Conditions}

Persons with medical conditions are just as likely to use transit on weekdays but more likely on Sundays and holidays. They use transit significantly more during midday but much less at night. They are far less likely to use transit for school or work, but far more for other purposes, especially for medical and dental purposes. Their trips are significantly more likely to be shorter than 1 mile long and to take at least 60 minutes. The speed of their transit trips is highly likely to be lower than $3 \mathrm{mph}$, but is also likely to be in the range of $15-25 \mathrm{mph}$.

They are more likely to wait for 10-14 minutes but are extremely likely to wait for at least 15 minutes. They are slightly more likely to walk for access or egress. They are extremely unlikely to use POVs for access but are far more likely to use them for egress. In addition, they are significantly more likely to use modes other than walk, transit, POVs, and bike for both access and egress. Their total access time is far more likely to be at least 15 minutes, and their total egress time is more likely to be at least 10 minutes.

\subsubsection{Income under $\$ 15,000$}

Persons with income under $\$ 15,000$ are more likely to use transit on weekend days and holidays and during midday but not at night. They use transit far more for purposes other than work and school. Their transit trips are more likely to be shorter than 2 miles long, take less than 15 minutes, and be at speeds lower than $5 \mathrm{mph}$ or in the range of $10-15 \mathrm{mph}$. They are significantly more likely to wait for at least 15 minutes. They are more likely to walk for access or egress and are extremely unlikely to use POVs for access or egress. Their total access time and total egress time are more likely to be at least 10 minutes.

\subsubsection{Zero Vehicle Households}

Persons without household vehicles use transit more during midday and night times and significantly more on weekend days and holidays. They use transit far more for purposes other than work and school. Their transit trips are more likely to be shorter than 5 miles, take less than 30 minutes, and be at speeds lower than $5 \mathrm{mph}$. Their transit trips are more likely to take at least 15 minutes for waiting. They are slightly more likely to walk for both access and egress. Their total access time is more likely to be less than 5 minutes, and their total egress time is more likely to be less than 15 minutes. 


\subsubsection{Hispanics}

Hispanics use transit far more on weekend days and holidays. They are more likely to use transit for school and medical and dental purposes. Their trips are far more likely to be shorter than 2 miles and are more likely to take 30 to 40 minutes and be at speeds lower than $5 \mathrm{mph}$. Hispanics are more likely to wait for at least 10 minutes. They are slightly more likely to walk for access and egress. Their total access time and total egress time are more likely to be in the range of 5 to 14 minutes.

\subsubsection{Non-Hispanic Blacks}

Non-Hispanic Blacks use transit more on Sundays and holidays and during midday. They use transit more for purposes other than work, school, or medical and dental purposes. The speeds of their transit trips are far more likely to be lower than $5 \mathrm{mph}$. They are far more likely to wait for at least 15 minutes. They are slightly more likely to walk for access or egress. They are extremely unlikely to bike for access or egress. Their total access time and total egress time are more likely to be at least 15 minutes.

\subsubsection{Most Frequent Users}

The most frequent users use transit less during midday and significantly less on Saturdays. They are far more likely to use transit for work purposes. The speed of their transit trips is more likely to be in the range of 3 to $25 \mathrm{mph}$. They are more likely to wait for less than 10 minutes. They are slightly more likely to walk for access, but they are more likely to use transit, POVs, or bike for egress. Both their total access time and total egress time are more likely to be less than 5 minutes.

\subsubsection{Work Trips}

Transit trips for work purposes are significantly less likely to be on weekend days and holidays. They are more likely to be during the afternoon peak period and are significantly more likely to be during the morning peak period. They are far more likely to be at least 5 miles long, to take at least 45 minutes, and to be at speeds at least $10 \mathrm{mph}$.

Transit trips for work purposes are far more likely to have waiting times less than 10 minutes. For access, POVs, bike, and modes other than these two and walk and transit are significantly more likely to be used. For egress, transit is more likely to be used, and POVs and bike are significantly more likely to be used. Their total access time is more likely to be in the range of 5-10 minutes. Their total egress time is more likely to be in the range of 5-9 minutes. 


\section{CONCLUSIONS}

Using data from the 2009 National Household Travel Survey (NHTS), the current study has defined and assessed a range of transit markets in Florida and the U.S. from a range of perspectives. This study has used six socio-demographics and two travel characteristics to define transit markets. The socio-demographics are driver status, immigration status, existence of medical conditions, household income, vehicle availability, and race and ethnicity. The travel characteristics are monthly frequency of transit use and the purpose of person-trips. The current study has assessed these markets from five perspectives:

1. Market Size - For each major mode and for all modes combined, the current study assessed these market segments in terms of their relative sizes by looking at how total travel is distributed across the set of market segments based on a given characteristic. It then compares market size with population size for the same markets to indicate how much persons in each market segment travel relative to the average person in the total population by each mode and by all modes combined.

2. Modal Share - For each market segment, the study determined the mode choices of its population among driving, riding in a privately-operated vehicle (POV), using transit, walking, biking, and other modes.

3. Attitudes - The study assessed the attitudes of persons in each transit market in terms of their choice of the most important issue among a set of six pre-specified transportation issues and their views on the seriousness of each issue. The six pre-identified transportation issues are:

- Highway congestion

- Access to and availability of transit

- Lack of walkways and sidewalks

- Price of travel

- Aggressive and distracted drivers

- Safety concerns

There are three levels for the seriousness of an issue:

- A little small issue (interpreted in this section as "not a problem")

- A moderate issue (interpreted in this section as "not a serious problem")

- A big issue (interpreted in this section as "a serious problem")

4. Socio-Demographics - The study assessed the socio-demographics of each transit market, i.e., the distribution of the transit trips within this market across a set of population segments defined on the basis of these socio-demographics. In addition to the six socio-demographic 
characteristics and frequency of transit use that are used to define transit markets in this study, the assessment also considered person age and two location characteristics: housing density in terms of housing units per square mile for census tracts, and whether a household is located in an urbanized area (UZA) and, if so, the population size of the UZA.

5. Trip Characteristics - The study assessed the trip characteristics of each transit market, including both transit-specific and general characteristics. The transit-specific characteristics include wait time, last access mode to the main mode, first egress mode from the main mode, total access time, and total egress time. The general characteristics include day of week, start time, trip purpose, trip distance, trip duration, and speed.

For the U.S. as a whole, the assessment was done for all five perspectives. For Florida, the assessment was done for the first three perspectives due to sample size considerations. The other sections highlight some of the results from the current study.

\subsection{Florida}

In percentage terms, the size of several transit markets is notably different between Florida and the U.S. On one hand, the size of most of these transit markets in Florida is much larger than those in the U.S. as a whole. Households with income under $\$ 15,000$ represent 41.9 percent of the entire transit market in Florida vs. 28.9 percent in the U.S. In addition, new immigrants capture 23.2 percent of all transit trips in Florida vs. 8.2 percent in the U.S. Finally, Hispanics and non-Hispanic Blacks together represent 75 percent of the entire transit market in Florida vs. 61.1 percent in the U.S. On the other hand, the percent of all transit trips for work purposes is much lower in Florida than in the U.S. -27.4 percent in Florida vs. 36.3 percent in the U.S.

Florida relies more heavily on travel by POVs than the U.S. as a whole. For example, persons in zero-vehicle households in Florida drive or ride as a POV passenger for almost one-fifth of the time (19.4 percent), almost twice as much as those in the U.S. as a whole (10.6 percent). But Florida relies less on walking. For example, new immigrants in Florida walk for 9.7 percent of the time, compared to 17.0 percent for the U.S. Also, Florida relies on transit about one-half as much as the U.S. Estimating directly from the variable on the main mode of individual person-trips in the 2009 NHTS, transit's mode share is 1.00 percent in Florida vs. 1.92 percent in the U.S. as a whole. However, transit's modal share varies significantly across the various transit markets. It is much lower than one-half of that of the U.S. for some of the transit markets, including older immigrants and transit trips for work purposes. On the other hand, it is much higher than one-half of that of the U.S. for several other transit markets, including zero-vehicle households, households with income under $\$ 15,000$, new immigrants, and transit users who use transit at least once per month.

The most important issue in Florida is access to and availability of transit, with 35.9 of transit trip makers seeing it being the most important issue. The least important issues are aggressive and distracted drivers and lack of walkways and sidewalks, with fewer than 10 percent of Floridians 
considering either of them as the most important issue. In comparison to the U.S. as a whole, Floridians are almost one-half as likely to rate the price of travel as the most important issue. Floridians are more likely than the U.S. to view access to and availability of transit, aggressive and distracted drivers, or safety concerns as the most important issue. However, Floridians are almost twice likely as the U.S. to consider highway congestion and lacking walkways and sidewalks as the most important issue.

\subsection{Market Size and Modal Share for the U.S.}

The results on market size and modal share are highlighted for nine key transit markets:

1. Non-drivers (persons ages $15+$ years who do not drive POVs)

2. New immigrants (i.e., entered the U.S. during 2000-2009)

3. Persons with medical conditions (making it difficult to travel outside of the home)

4. Hispanics

5. Non-Hispanic Blacks

6. Income under $\$ 15,000$

7. Zero-vehicle households

8. Most frequent users (those using transit $30+$ times/month)

9. Work purposes

Most key transit markets travel significantly less than the average person in the total population, as indicated by their level of relative general mobility by all modes. For a given market, its relative general mobility by all modes is the ratio of its share of the total travel by all modes over its share of the total population. The most frequent users of transit are the only key market that travels more than the average person. Persons in all other key markets travel less than the average person in the total population. New immigrants, Hispanics, and Non-Hispanic Blacks travel about 90 percent of what the average person in the total population travels. Persons with annual household income under $\$ 15,000$ travel about 75 percent of what the average person travels. Persons with medical conditions travel about 60 percent of what the average person travels. Non-drivers and persons in zero-vehicle households travel only one-half as much as the average person. The level of general mobility is important because, for a given transit market with a given level of transit modal share, a higher level of general mobility means a higher level of transit ridership.

For the U.S. as a whole, persons in zero-vehicle households and the most frequent users of transit constitute 48.5 percent and 43.4 percent of the overall transit market, respectively. Work trips are 36.3 percent of the overall transit market. Hispanics, Non-Hispanic Blacks, and persons with household income under $\$ 15,000$ capture about 30 percent of the overall transit market. Nondrivers, new immigrants, and persons having medical conditions represent significantly smaller markets for transit. 
The role of transit in each key market varies dramatically. The most frequent users of transit rely on transit for more than one-third of their total travel. Persons in zero-vehicle households use transit more than one-quarter of the time. The reliance on transit is well under 10 percent for persons with household income under $\$ 15,000$, Non-Hispanic Blacks, and new immigrants. Those who travel for work purposes, Hispanics, persons with medical conditions, and non-drivers depend even less on transit, with a transit modal share under 5 percent.

POV driving and riding dominate all other modes for work trips, with a total share of 88.7 percent. POV driving and riding serve around three-quarters of all person-trips for new immigrants, persons with medical conditions, Hispanics, and Non-Hispanic Blacks and two-thirds of the travel for persons with household income under $\$ 15,000$. Non-drivers rely on POV riding for one-half of their travel. The role of POVs is 29.3 percent for the most frequent users and 10.6 percent for persons in zero-vehicle households.

Walking plays a significant role for most of the key markets. Its modal shares are 48.6 percent for persons in zero-vehicle households, about 30 percent for non-drivers and the most frequent transit users, 19.5 percent for persons with household income under $\$ 15,000$, and a range of 12.8-17.0 percent for persons with medical conditions, Non-Hispanic Blacks, Hispanics, and new immigrants. Walking captures only 6 percent of all work trips.

Biking serves no greater than 3 percent of all travel for any of the key markets. This is true even for those markets whose modal share of walking is as high as 30 percent (non-drivers and the most frequent users of transit) or nearly 50 percent (zero-vehicle households).

Transit plays a minor role even for some of the markets that are traditionally considered to be transit-dependent. For example, transit's modal share is 4.5 percent among non-drivers and 6.9 percent among persons in households with income under $\$ 15,000$.

\subsection{Attitudes of U.S. Travelers and Transit Users}

For trip makers of all modes, the most significant issue is the price of travel, with 37.7 percent choosing it as the most important issue. The least significant issues are access to and availability of transit and lacking walkways and sidewalks, with only 7.5 percent choosing access to and availability of transit and 3.4 percent choosing lacking walkways and sidewalks. The other three issues-highway congestion, aggressive and distracted drivers, and safety concerns-fall in the middle at 15.1 percent, 17.7 percent, and 18.5 percent, respectively.

The most important issues do not vary much across the modes. An exception relates to the issue of access to and availability of transit. It is more significant to trip makers of transit, walking, and biking than those of other modes, is the most important issue to almost one-third of transit trip makers, and about 14.0 percent of trip makers via walking and biking. 
To transit trip makers, the most significant issues are access to and availability of transit and the price of travel, with about one-third choosing each as the most important issue. Another 15 percent choose safety concerns as the most important issue. Fewer than 10 percent chose each of the other three issues as the most important. This pattern of attitudes is largely consistent across the various transit markets considered.

For trip makers of all modes, 60.3 percent consider the price of travel as a serious problem and 55.2 percent consider access to and availability of transit as a serious one. Less than one-half consider each of the other issues to be a serious problem. A larger proportion of transit trip makers consider these issues to be serious than do trip makers of other modes. In addition, each issue is seen as a serious problem by at least 50 percent of transit trip makers.

Few transit trip makers view lack of walkways and sidewalks as the most important issue, but many see it as a serious problem. Only 4.1 percent of all transit trip makers view it as the most important issue, but 55.0 percent of them see it as a serious problem, with another 31.8 percent seeing it as a problem but not a serious one.

\subsection{Socio-Demographics of U.S. Transit Markets}

It has been reported in the media that newly-arrived immigrants are settling in all corners of the country rather than concentrating in large and dense urban areas as previous generations of immigrants have done. As shown in Table 7.1, there is some evidence from the current study indicating that this settlement pattern of new immigrants is starting to be reflected in the geographic pattern of the transit trips they make.

Table 7.1. Spatial Pattern of Transit Markets by Immigrant Status

\begin{tabular}{|c|c|c|c|c|c|}
\hline \multirow{2}{*}{\multicolumn{2}{|c|}{ Socio-Demographics }} & \multicolumn{3}{|c|}{ Immigration Status } & \multirow{2}{*}{$\begin{array}{c}\text { Total } \\
\text { Transit } \\
\text { Market }\end{array}$} \\
\hline & & $\begin{array}{c}\text { New } \\
\text { Immigrant }\end{array}$ & $\begin{array}{c}\text { Older } \\
\text { Immigrant }\end{array}$ & $\begin{array}{c}\text { Non } \\
\text { Immigrant }\end{array}$ & \\
\hline \multirow{4}{*}{$\begin{array}{l}\text { Housing } \\
\text { Units per } \\
\text { Square Mile }\end{array}$} & $0-999$ & $5.7 \%$ & $2.2 \%$ & $11.2 \%$ & $8.7 \%$ \\
\hline & $1,000-3,999$ & $32.8 \%$ & $25.0 \%$ & $33.1 \%$ & $31.2 \%$ \\
\hline & $4,000+$ & $61.6 \%$ & $72.8 \%$ & $55.7 \%$ & $60.1 \%$ \\
\hline & All & $100.0 \%$ & $100.0 \%$ & $100.0 \%$ & $100.0 \%$ \\
\hline \multirow{5}{*}{$\begin{array}{l}\text { Status and } \\
\text { Size of } \\
\text { Urbanized } \\
\text { Areas (UZA) }\end{array}$} & UZA 50,000 - 199,999 & $4.1 \%$ & $1.5 \%$ & $3.4 \%$ & $3.0 \%$ \\
\hline & UZA 200,000 - 999,999 & $4.8 \%$ & $6.2 \%$ & $12.4 \%$ & $10.4 \%$ \\
\hline & UZA 1 million+ & $86.8 \%$ & $90.2 \%$ & $80.1 \%$ & $83.0 \%$ \\
\hline & Non UZA & $4.4 \%$ & $2.1 \%$ & $4.0 \%$ & $3.6 \%$ \\
\hline & All & $100.0 \%$ & $100.0 \%$ & $100.0 \%$ & $100.0 \%$ \\
\hline
\end{tabular}

In terms of the distribution of transit trips across census tracts of different housing density, the pattern of new immigrants is similar to that of non-immigrants, but the pattern of older immigrants differs significantly from both. 
In terms of the distribution of transit trips across non-urbanized areas and urbanized areas of different sizes, the pattern of new immigrants is similar to that of non-immigrants but differs from that of older immigrants. Of particular interest in this case are non-urbanized areas and urbanized areas with population under 200,000 . These areas capture 8.5 percent of the transit trips by new immigrants and 7.4 percent of the transit trips by non-immigrants, but only 3.6 percent of those by older immigrants.

New immigrants have been an important transit market. One reason that new immigrants in the past were a good source of transit ridership is that they were settling in large and dense urban areas. If an increasing number of future new immigrants choose to settle in areas with low or extremely low density, however, much of the potential of new immigrants as a transit market may be lost. At a minimum, trends about their patterns of settlement and trip making should be monitored.

The following highlights some of the results for several of the nine key transit markets:

- Non-Drivers - The least frequent users of transit constitute 12.8 percent of the driver market, but 25 percent of the non-driver market. Hispanics constitute 24 percent of the driver market, but 50.4 percent of the non-driver market. Persons with income under $\$ 50,000$ constitute 65.2 percent of the driver market, but 89.3 percent of the non-driver market.

- New Immigrants - New immigrants are significantly over-represented by non-drivers and Hispanics. Non-drivers constitute 9.9 percent of the non-immigrant market but 26.9 percent of the new-immigrant market. Hispanics constitute 16.5 percent of the non-immigrant market, but 56.9 percent of the new-immigrant market.

- Having Medical Conditions - Persons with medical conditions are significantly overrepresented by persons with income under $\$ 15,000$ and zero-vehicle households. Persons with income under $\$ 15,000$ capture 24.5 percent of the transit trips by persons without medical conditions, but 58.2 percent of the transit trips by persons with medical conditions.

- Income under $\$ 15,000$ - Non-Hispanic Blacks constitute14.2 percent of the high-income market (households with income at least $\$ 100,000$ ), but 51.4 percent of the low-income market (households with income under $\$ 15,000$ ). Zero-vehicle households constitute16.7 percent of the high-income market, but 74.1 percent of the low-income market.

- Zero-Vehicle Households - Persons with income under $\$ 15,000$ constitute 14.8 percent of the transit market of households with adequate vehicles (i.e., vehicles $\geq$ workers), but 43.7 percent of the transit market of zero-vehicle households. Non-Hispanic Blacks constitute 
22.9 percent of the transit market of households with adequate vehicles, but 41.6 percent of the transit market of zero-vehicle households. Residents from Census tracts with housing density $4,000+$ units per square mile constitute 40.3 percent of the transit market of households with adequate vehicles, but 70.9 percent of the transit market of zero-vehicle households.

Finally, older adults (65+) make 8.2 percent of all transit trips, but are a higher share of some of the transit sub-markets, including non-drivers (12.1\%), older immigrants (15.4\%), persons with medical conditions (16.7\%), persons with income under $\$ 15,000(12.4 \%)$, zero-vehicle households $(11.8 \%)$, and the least frequent users of transit (17.9\%). Older adults also constitute 22 percent of all transit trips for medical and dental purposes.

\subsection{Trip Characteristics of U.S. Transit Markets}

Two points are notable on the trip characteristics of transit markets for the U.S. as a whole. One relates to the percent of transit trips for work purposes, which is motivated by the extremely high percentage reported by APTA (2007). The other point relates to the transit level of service in terms of the trip characteristics of several key transit markets of particular policy interest.

Figure 7.1 summarizes the results on the percent of transit trips for work purposes for each of the transit markets considered in the report. The percent of trips for work purposes varies dramatically across the various transit markets. At the lower end, it is only 9.7 percent among non-drivers, 12.4 percent among the least frequent users of transit, and 17.1 percent among persons with medical conditions. At the high end, it is 55.6 percent among persons with household income at least $\$ 100,000$ and 57.1 percent among persons with fewer vehicles than workers in their households.

The level of service is poorer with respect to several important service characteristics for many of the key transit markets considered in this report, including non-drivers, persons having medical conditions, persons with income under \$15,000, zero-vehicle households, Hispanics, and NonHispanic Blacks. For these transit market segments, transit trip makers are more likely to wait longer, take longer for access and egress, and travel at lower speeds.

These transit markets are more likely to use transit for person-trips of shorter distance, and a large portion of the total duration for a transit trip of short distance is access and egress times. These transit markets are more likely to use transit at times when the amount of service is lower than other times. For example, non-drivers are far more likely to use transit on weekend days and holidays and during midday and night times. Many persons in these markets are likely not to be in the workforce, and when they are employed, their work schedule may not follow the typical schedule of $8 \mathrm{am}$ to $5 \mathrm{pm}$ on weekdays. Another potential reason for longer waiting time for these transit markets is that persons in these transit markets may be less sensitive about timing their arrival at transit stops and stations than other transit markets. 


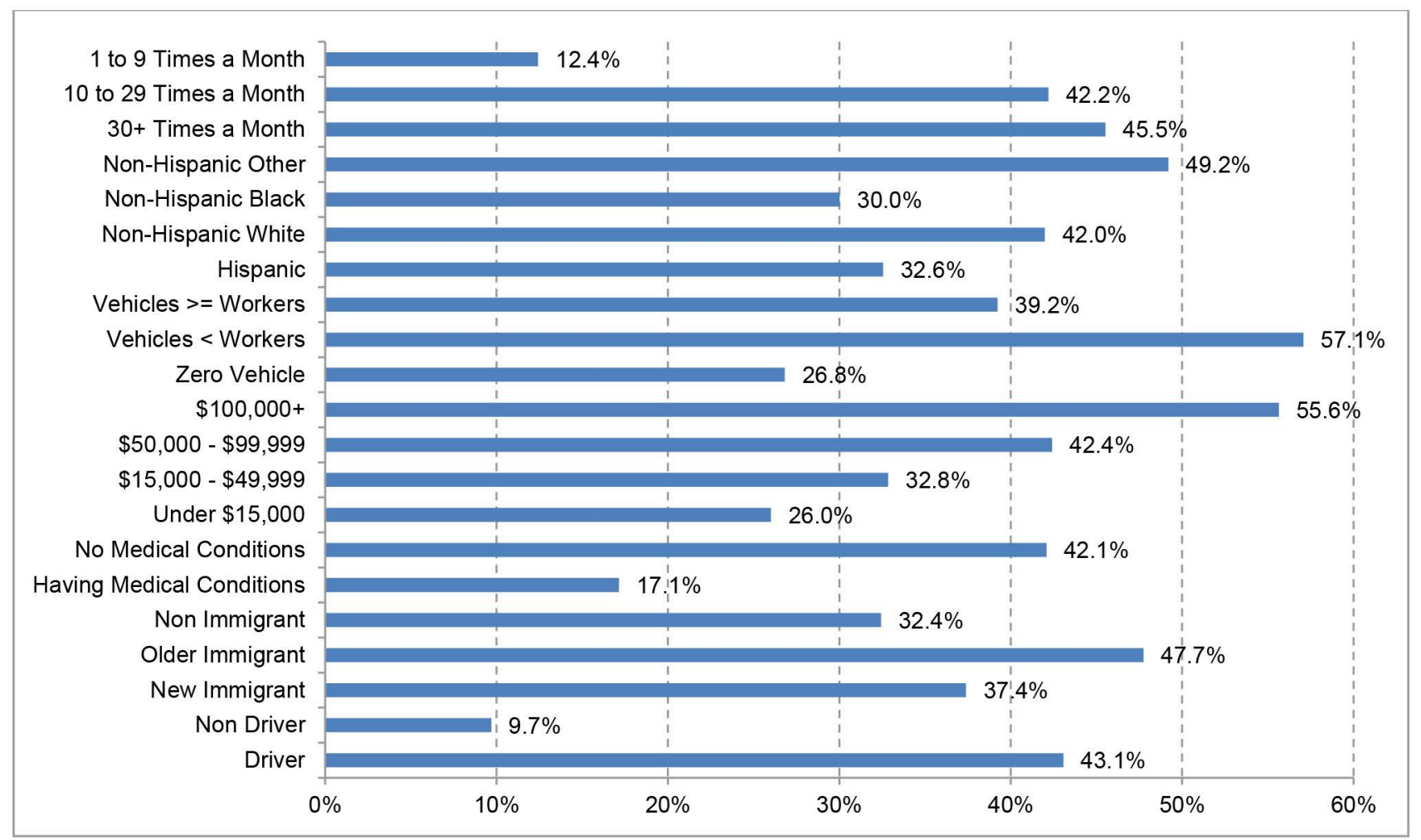

Figure 7.1. Percent of Transit Trips for Work Purposes by Travel Segment 


\section{REFERENCES}

American Public Transportation Association. A Profile of Public Transportation Passenger Demographics and Travel Characteristics Reported in On-Board Surveys. Washington, D.C., 2007.

Cambridge Systematics. Transit Market Research Models. Washington State Department of Transportation, 2009.

Center for Urban Transportation Research. Public Transit in America: Results from the 2001 National Household Travel Survey. University of South Florida, Tampa, 2005.

Elmore-Yalch, Rebecca. A Handbook: Using Market Segmentation to Increase Transit Ridership. TCRP Report 36. Transportation Research Board of the National Academies, Washington, D.C., 1998.

Elmore-Yalch, Rebecca. A Handbook: Integrating Market Research into Transit Management. TCRP Report 37. Transportation Research Board of the National Academies, Washington, D.C., 1998.

Federal Highway Administration (FHWA). National Household Travel Survey. http://nhts.ornl.gov/. Accessed February 27, 2012.

Hemily, Brendon. Trends Affecting Public Transit's Effectiveness: A Review and Proposed Actions. American Public Transportation Association, Washington, D.C., 2004.

McCollom Management Consulting. Transit Performance Monitoring System (TPMS) Results:

Summary Report Phases I and II. American Public Transportation Association and Federal Transit Administration, Washington, D.C, 2002.

McCollom Management Consulting. Transit Performance Monitoring System (TPMS) Results: Summary Report Phases III. American Public Transportation Association and Federal Transit Administration, Washington, D.C., 2004.

Rosenbloom, Sandra. Transit Markets of the Future: The Challenge of Change. TCRP Report 28. Transportation Research Board of the National Academies, Washington, D.C., 1998. 